$$
\text { UNIVERSIDADE DE SÃO PAULO }
$$

FACULDADE DE FILOSOFIA, LETRAS E CIÊNCIAS HUMANAS PROGRAMA DE PÓS-GRADUAÇÃO EM HISTÓRIA ECONÔMICA

\title{
Poder local e patrimonialismo: A Câmara Municipal e a concessão de terras urbanas na vila de São Paulo
} (1560-1765)

Fernando V. Aguiar Ribeiro

Dissertação apresentada ao Programa de Pós-Graduação em História Econômica da Faculdade de Filosofia, Letras e Ciências Humanas da Universidade de São Paulo, para a obtenção do título de Mestre em Ciências.

Orientadora: Profa. Dra. Raquel Glezer 


\section{Agradecimentos}

À Prof ${ }^{\mathrm{a}}$. Dr ${ }^{\mathrm{a}}$. Raquel Glezer, pela orientação, confiança e pelo exemplo de professora e pesquisadora.

Aos membros da Banca de Qualificação, Prof. Dr. Murillo Marx e Prof ${ }^{\mathrm{a}}$. Drª . Vera Lucia Amaral Ferlini, pelas indicações e apoio no processo de elaboração da pesquisa.

Aos professores Ana Paula Torres Megiani, Beatriz P. Siqueira Bueno, Denise Soares Moura, Fernando Antonio Novais, Fernando de Souza Coelho, Hugo M. Segawa, Ignacio M. Poveda Velasco, Joaquim Romero Magalhães, Leonor Freire da Costa e Rodrigo M. Ricupero que contribuíram com questionamentos e sugestões à pesquisa.

Aos funcionários do Instituto de Estudos Brasileiros, Maria Itália Causin, Diva de Souza Ferrari e Maria Marta de Oliveira.

Ao Arquivo Histórico Municipal Washington Luís, à diretora Liliane Schrank Lehmann e, em especial, à Maria Aparecida Baptista Gusmão.

Aos colegas, Carlos Eduardo Rovaron, Flávia Maíra de Araújo Gonçalves, Francismar Lopes de Carvalho, Igor R. Machado de Lima, Joaquim Xavier Júnior, Lorena Leite, Lucas Jannoni Soares, Marly Spacachieri, Maximiliano Mac Menz, Pablo Oller Mont Serrath, Patrícia Cardoso, Patrícia Valim, Renato Soares Bastos e Thiago Lima Nicodemo.

Aos amigos Bárbara Assaf, Daniel Gonzáles, Heloisa F. Turek, Juliana de Souza Batista, Marianne Schaeffer e Paula Coelho.

Ao meu pai José Carlos Ribeiro, à minha mãe Olga Maria Agiar Ribeiro e minhas irmãs Fabíola e Marília pelo apoio incondicional.

Ao CNPq pelo auxílio e ao Programa de Pós-Graduação em História Econômica pela aquisição do aplicativo SPSS, sem os quais essa pesquisa não seria possível. 


\section{Resumo}

Essa dissertação pretende compreender as relações entre o grupo político local dominante, representado pelos ocupantes da Câmara Municipal e a concessão de terras urbanas. Para tanto, utilizamos as Atas da Câmara de São Paulo, Registro Geral da Câmara e as Cartas de Datas de Terra de São Paulo. Essas fontes documentais foram cruzadas e tratadas de forma estatística através do aplicativo SPSS.

Adotando uma abordagem quantitativa, pudemos melhor compreender a estrutura do poder local em São Paulo, caracterizada por relações de cunho patrimonialista. Relações essas que marcaram o processo de urbanização do núcleo urbano e o povoamento do planalto antes de 1765 .

Palavras-chave: São Paulo; urbanização; poder local; terra urbana; patrimonialismo 


\begin{abstract}
This thesis attempts to study relantionships between the dominant local policital group, represented by the occupants of Câmara Municipal (the municipal council) and the granting of urban proprieties. We used Atas da Câmara de São Paulo, Registro Geral and Cartas de Datas de Terras. These documental sources were combined and treated statistically using the SPSS application.

Adopting a quantitative approuch, we could understand the structure of local government in São Paulo, caracterized by relations of patrimonial nature. Relations that caracterized the urbanization process and urban area population of the plateau before 1765 .
\end{abstract}

Key-words: São Paulo; urbanization; local government; urban territory; patrimonialism 


\section{Sumário}

INTRODUÇÃO

1 A CONSTRUÇÃO DO OBJETO 12

$\begin{array}{ll}1.1 \text { HISTORIOGRAFIA SOBRE SÃO PAULO } & 13\end{array}$

1.2 HISTORIOGRAFIA SOBRE URBANIZAÇÃO 20

1.3 HISTORIOGRAFIA SOBRE ADMINISTRAÇÃO COLONIAL 28

1.4 HISTORIOGRAFIA SOBRE PODER LOCAL 54

1.5 ESTADO ATUAL DA QUESTÃO SOBRE FONTES DO DIREITO PORTUGUÊS 59

2 FONTES E BANCOS DE DADOS

$\begin{array}{ll}2.1 \text { FONTES } & 81\end{array}$

$\begin{array}{ll}2.2 \\ \text { BANCO DE DADOS } & 99\end{array}$

2.3 RESULTADOS OBTIDOS 112

3 PATRIMONIALISMO E PODER LOCAL 129

3.1 O PODER LOCAL NO ESPAÇO COLONIAL PORTUGUÊS NA AMÉRICA:

$\begin{array}{ll}\text { O CASO DE SÃO PAULO } & 130\end{array}$

3.2 CONSEQUÊNCIAS DO PODER LOCAL NA URBANIZAÇÃO DE SÃO PAULO 143

3.3 A CRIAÇÃO DE VILAS SERRA-ACIMA 159

CONSIDERAÇÕES FINAIS 186

$\begin{array}{ll}\text { REFERÊNCIAS } & 189\end{array}$ 


\section{Lista de Ilustrações}

Gráfico 1 - Relação entre localização e cargos honorários

Gráfico 2 - Relação entre localização e dimensão das terras concedidas

Gráfico 3 - Relação entre vínculo com a câmara e dimensão das terras concedidas

Gráfico 4 - Relação entre cargos honorários e dimensão das terras concedidas

Gráfico 5 - Distribuição de terras por anos

Mapa 1 - Topografia da área central da cidade de São Paulo

Mapa 2 - Planta da Restauração (1765)

Mapa 3 - Mapa de vilas fundadas no planalto 


\section{Lista de Tabelas}

Tabela 1 - Volume de Atas da Câmara na edição transcrita

Tabela 2 - Atas da Câmara de São Paulo (1560-1765)

Tabela 3 - Registro Geral da Câmara de São Paulo (1583-1765)

Tabela 4 - Vínculo com a Câmara Municipal

Tabela 5 - Relações de parentesco com o oficiais da Câmara

Tabela 6 - Concessões por gênero

Tabela 7 - Padrões de argumentação na solicitação de terras

Tabela 8 - Terras concedidas aos escrivães

Tabela 9 - Concessões de terras feitas para ocupantes de cargos honorários

Tabela 10 - Localização das concessões de terra 
Introdução 
O presente trabalho tem como objetivo central o estudo das relações patrimonialistas entre os oficiais da Câmara da vila de São Paulo através da concessão de terras urbanas.

O início da colonização portuguesa nas Américas se deu com a doação de capitanias $^{1}$ e a fundação de municípios. São Vicente, o primeiro município estabelecido na América Portuguesa data de 1532.

A vila de São Paulo teve origem diferente de algumas outras do mesmo período. Resultou da transferência, em 1560, do pelourinho de Santo André para o sítio no qual os jesuítas fundaram um Colégio anos antes. A vila de São Paulo surgiu com uma transferência de sede e não uma fundação.

Tal qual os municípios do reino, as novas instituições coloniais foram dotadas das mesmas estruturas, direitos e obrigações: eleição para compor a Câmara, obrigação de proteger a terra às suas custas e a propriedade e jurisdição de uma área de 6 léguas ao redor da vila² .

Essa homogeneidade dos municípios no Império Português se deu por conta das características jurídico-administrativas de Portugal. Enquanto que Castela criou uma legislação especial para seus domínios ultramarino, as Leyes de Índias, Portugal estendeu suas Ordenações a todo o seu Império³.

Dessa forma, a legislação referente aos municípios em Portugal, assim como referentes aos demais aspectos administrativos, como finanças, defesa e privilégios, eram as mesmas em todo o Império.

A Câmara Municipal, à época colonial, não respondia, como nos dias atuais, apenas às questões administrativas locais. Competia-lhe também proteger as conquistas do rei, garantir a justiça no âmbito local e arrecadar tributos à Coroa ${ }^{4}$.

As câmaras, conforme normatiza as Ordenações, eram compostas de juiz ordinário, vereadores, procurador do Concelho, almotacel e alcaide. Esses tinham, respectivamente, as funções

1 Cf. António Vasconcelos de Saldanha. As capitanias. O regime senhorial na Expansão Ultramarina Portuguesa. Funchal: CEHA, 1991, p. 61.

2 Cf. Ordenações Filipinas. Liv. I, tít, LXV e LXVI.

3 Sérgio Buarque de Holanda. Raízes do Brasil. São Paulo: Companhia das Letras, p. 96.

4 Edmundo Zenha. O município no Brasil. São Paulo: IPE, 1948, p. 31. 
de garantir a justiça, executar as leis e compor as posturas municipais, representar o Concelho fora desse, fiscalizar vendas conforme as posturas e garantir paz e tranqüilidade na vila ${ }^{5}$.

Os três primeiros cargos (juiz ordinário, vereadores e procurador do Concelho) não eram remunerados, ao contrário dos demais. Eram cargos honorários, os quais deveriam ser ocupados pelos mais preeminentes da vida local ${ }^{6}$.

Por não serem remunerados, e por representarem os elementos mais destacados da sociedade, não é de se espantar que considerassem essa situação, somada ao cargo que ocupavam, como privilégios.

Esses privilégios levariam à confusão entre público e privado na administração municipal. Isto é, não haveria separação entre a propriedade pessoal dos oficiais da Câmara e o patrimônio dessa.

Assim, as terras urbanas, terras pertencentes ao município e situadas dentro de sua jurisdição, eram, muitas vezes, concedidas para ocupantes de cargos na Câmara.

No entanto, antes de desenvolvermos detalhadamente os objetivos dessa dissertação, devemos refletir acerca de alguns conceitos fundamentais para a pesquisa, tais como patrimonialismo, poder local, terra urbana e concessão / doação.

A noção de patrimônio e patrimonialismo podem, em um primeiro momento, evocar a idéia de acumulação de capital por parte de um indivíduo ou grupo. No entanto, o conceito de patrimonialismo utilizado nessa dissertação refere-se ao definido por Max Weber.

Em Economia e sociedade, o autor aponta que "toda dominação manifesta-se e funciona como administração. Toda administração precisa, de alguma forma, da dominação, pois, para dirigila, é mister que certos poderes de mando se encontrem nas mãos de algum"7. Essa dominação pode, em sociedades pré-burocráticas, como é o caso do Brasil colonial, ser tradicional, "quando sua

5 António M. Hespanha. História de Portugal moderno. Político e institucional. Lisboa: Universidade Aberta, 1995, p. $162-164$.

6 António M. Hespanha. As vésperas do Leviathan. Coimbra: Almedina, 1994, p. 164.

7 Max Weber. Economia e sociedade. São Paulo; Brasília: Imprensa Oficial: UnB, 2003, p. 193, vol. II. 
legitimidade repousa na crença na santidade de ordens e poderes senhoriais tradicionais (existentes desde sempre)"8 ou patrimonial que é "originalmente orientada pela tradição e se exerce em virtude de pleno direito pessoal"".

Como principal característica da dominação do tipo patrimonial, Weber ressalta a falta da distinção entre a esfera 'privada' e a 'oficial' na atuação do funcionário. Afirma que "a administração política é tratada como assunto puramente pessoal do senhor, e a propriedade e o exercício de seu poder político, como parte integrante de seu patrimônio pessoal aproveitável em forma de tributos e emolumentos"10.

O poder local, isto é, a atuação dos oficiais da Câmara nos municípios dentro do Império Português, é um conceito que precisa ser mais bem problematizado.

De acordo com Nuno Gonçalo Monteiro, a origem de Portugal, por meio da conquista de terras, garantiu ao reino uma homogeneidade institucional. Como consequência, aponta que "um dos legados dessas origens e dessa história era, precisamente, a inexistência tendencial de 'corpos políticos intermédios' entre o centro e a esfera local" ${ }^{11}$.

Encontramos em Portugal o poder local e o central interagindo sem intermediário ${ }^{12}$. Logo a questão centro e periferia, representada pela discussão sobre a centralização precoce do reino, se tornariam pontos capitais da discussão historiográfica portuguesa sobre a época.

A imagem da centralização precoce é apontada por Monteiro tendo como seu principal difusor Alexandre Herculano. Para ele,

a tese de Herculano fez escola tanto nas correntes conservadoras (em especial, nas influenciadas pelo integralismo lusitano) como nas

8 Max Weber. op. cit., p. 148, vol. I.

9 Max Weber. op.cit., p. 152, vol. I.

10 Max Weber. op. cit., p. 253, vol. II.

11 Nuno Gonçalo Monteiro. Elites e poder. Entre o Antigo Regime e o Liberalismo. Lisboa: ICS-UL, 2007, p. 24.

12 A situação começa a mudar com a criação do Conselho Ultramarino em 1642 (Cf. Marcelo Caetano. O Conselho Ultramarino: esboço de sua história. Lisboa: Agência Geral do Ultramar, 1967, p. 3) e o processo de incorporação das capitanias pela Coroa (Cf. António Vasconcelos de Saldanha. op. cit., p. 261). 
democráticas, as quais mutualmente se responsabilizaram pela dita centralização. Até bem pouco tempo, a omnipresença da coroa, a idéia da centralização precoce (ou o paradigma da centralização contínua e interminável, pois era um processo cujos inícios se chegavam a localizar no século XIII), a utilização dos conceitos de Estado e de nação num sentido quase contemporâneo para falar da história portuguesa desde os finais da Idade Média, constituíam patrimônio comum dos historiadores portugueses, quase sem exepção ${ }^{13}$.

A viragem historiográfica se deu, sobretudo, nos anos 80 do século XX. Podemos destacar, como obras importantes por tratar da crítica à centralização precoce e uma consequente valorização dos estudos municipais e locais, trabalhos de António Manuel Hespanha ${ }^{14}$ e Joaquim Romero Magalhães ${ }^{15}$.

Como consequência desses trabalhos, Nuno Gonçalo assinala que esses permitiram “a renovação da história dos municípios portugueses, tendo como um dos tópicos essenciais a análise das oligarquias camarárias"16.

Dentre outras atribuições das câmaras municipais, estava a concessão de terras. Antes de conceituarmos a doação, é necessário que reflitamos sobre a terra urbana e suas diferenças das sesmarias.

Raquel Glezer, ao analisar a documentação sobre terras, verifica que há diferença entre sesmaria e terra urbana. Afirma que "a primeira podia ser obtida por ato do rei, diretamente, ou via donatário, seu loco-tenente na ausência deste, do governador geral ou do capitão-general, com condição de exploração e livre de 'foro' pelo menos até o final do século XVII, mediante a exigência de pré-requisitos do solicitante como capital e situação social" ${ }^{17}$.

Já para a data de terra, essa “era cedida pela Câmara, instância de poder local, detentora de

13 Nuno Gonçalo Monteiro. op. cit., p. 261.

14 António M. Hespanha. op. cit.

15 Joaquim Romero Magalhães. Algarve económico durante o século XVI. Lisboa: Cosmos, 1970.

16 Nuno Gonçalo Monteiro. op. cit., p. 39.

17 Raquel Glezer. Chão de terra e outros estudos sobre São Paulo. São Paulo: Alameda, 2007, p. 58. 
um ‘termo' sobre o qual tinha jurisdição legal, jurídica, militar, econômica e administrativa, com o poder de conceder terra para moradias e exploração, quer gratuitamente, quer através do 'foro', que era parte de seus rendimentos" $"$.

Outra diferença entre as duas formas de propriedade era a dimensão territorial. Enquanto que as sesmarias "podiam ser de tamanho variado, mas nos primórdios da colonização abrangiam de uma a três léguas, simples ou em quadra, mas os 'chãos de terra' eram dados ou cedidos graciosamente em braças" ${ }^{19}$.

O conceito de concessão deve ser compreendido como a capacidade da Câmara de oferecer terras em sua propriedade a seus moradores. Raphael Bluteau, em seu Vocabulario, define concessão como "permissañ, privilegio, doaçaô" e conceitua doação como "acto publico, em virtude do qual trespassa o donatário a quem quer a propriedade, ou o usu fruto dos seus bens, ou de huma parte delles" ${ }^{21}$.

Apesar de ser à época termos correlatos, concessão e doação implicam em abordagens diferentes. A doação implica na relação entre doador àquele que doa e torna-se donatário o sujeito que recebe. Tal ato foi realizado com as capitanias hereditárias, no qual o rei doa partes de suas conquistas a donatários, revertendo essa doação apenas por meio de compra ${ }^{22}$.

As terras urbanas, no entanto, não garantiam tais privilégios. Após a Lei das Sesmarias de D. Fernando $^{23}$, compelia-se o proprietário de terras, tanto rurais como urbanas, a lavrá-la em certo período de tempo, com o risco de essas serem revertidas à instituição que a distribuiu.

O conceito de concessão, por reforçar a concepção de cessão de terras visando o povoamento e a produção agrícola apresenta-se como o melhor apontado para a problematização

18 Raquel Glezer. op. cit., p. 58.

19 Raquel Glezer. op. cit., p. 58.

20 Raphael Bluteau. Vocabulario portuguez e latino, aulico, anatomico, architectonico, bellico, bottanico... et alli. Coimbra: Collegio das Artes da Companhia de Jesus, 1712, p. 434-435.

21 Raphel Bluteau. op. cit., p. 273.

22 Cf. António Vasconcelos de Saldanha. op. cit., p. 261.

23 Ruy Cirne Lima. Pequena história territorial do Brasil: sesmarias e terras devolutas. Goiânia: EdUFG, 2002, p. 17. 
desse trabalho. $\mathrm{O}$ conceito de doação, que se mistura à noção de benefício, acaba por nos levar a caminhos equivocados, como pensar que a questão da oferta de terras ser fruto da liberalidade do rei.

A partir da discussão dos conceitos básicos podemos apresentar os objetivos da pesquisa.

Pretendemos compreender as relações entre o grupo político local dominante, representado pelos ocupantes da Câmara Municipal e a concessão de terras urbanas.

Optamos pela terra urbana devido à carência de estudos ${ }^{24}$, pois a historiografia sobre terras dedica-se quase que exclusivamente às sesmarias ${ }^{25}$.

Autores que tratam da terra urbana, dos quais destacamos Taunay, a apresenta, geralmente, como voltada aos moradores pobres de São Paulo, para a subsistência desses e, portanto, sem destaque político ou econômico ${ }^{26}$.

O estudo recente de Raquel Glezer, Chão de terra: um estudo sobre São Paulo colonial, ao tratar da terra urbana, permitiu que se iniciasse uma temática nova.

Outra abordagem que somente foi possível graças a novos estudos foi a análise do patrimonialismo nas relações políticas dos oficiais da Câmara.

Florestan Fernandes, em Circuito Fechado, aborda a colonização portuguesa e formação do Brasil contemporâneo na ótica weberiana, adaptando os conceitos para a realidade nacional ${ }^{27}$.

No entanto, foi na tese de doutorado de Rodrigo Ricupero ${ }^{28}$, de 2005 , que a análise da formação da elite colonial, seguindo os passos de Weber e Florestan, mais contribuiu para a presente temática.

Ao estudar o patrimonialismo nas relações sociais, políticas e econômicas das elites,

24 Cf. Raquel Glezer. op. cit., p. 54.

25 Trabalhos como de Virginia Rau. Sesmarias medievais portuguesas. Lisboa: Presença, 1982; Ruy Cirne Lima. op. cit., Ligia Osório Silva. Terras devolutas e latifúndio: efeitos da Lei de 1850. Campinas: Unicamp, 1996 e Márcia M. Motta. Direito à terra no Brasil: a gestação do conflito (1795-1824). São Paulo: Alameda, 2009.

26 Afonso de Escragnolle Taunay. São Paulo nos primeiros anos e São Paulo no século XVI. São Paulo: Paz e Terra, 2003, p. 107.

27 Florestan Fernandes. Circuito fechado. São Paulo: Hucitec, 1976, p. 31-32.

28 Rodrigo M. Ricupero. A formação da elite colonial. São Paulo: Alameda, 2009. 
Ricupero permite que reflitamos sobre o poder local em São Paulo em uma nova perspectiva.

A partir dessas questões, apresentamos a hipótese que norteou nossa pesquisa. Por optarmos em analisar o poder local e a concessão de terras, a abordagem patrimonialista torna-se fundamental.

Com isso, levantamos a possibilidade que a terra municipal, que foi concedida por ser patrimônio da Câmara, tenha sido apropriada pelos oficiais dessa como patrimônio seu. Assim, a concessão das terras privilegiaria os ocupantes dos cargos municipais, concentrando em suas famílias não só o controle político, mas também avançando pelo econômico.

As Cartas de datas de terra de São Paulo, documentação camarária referente às terras urbanas concedidas, em nossa hipótese, devem conter como requerentes de propriedades integrantes do poder político local.

Delimitamos para a compreensão das relações patrimonialistas na Câmara de São Paulo o período entre os anos de 1560 e 1765. A escolha da primeira data se deu por ser esse o ano da instalação do município de São Paulo.

Afirma Taunay que a transferência do município de Santo André para o sítio no qual os jesuítas haviam se instalado anos antes ocorreu para possibilitar a "concentração das forças esparsas, então diminutas, dos brancos do planalto ante a ameaçadora atitude dos silvícolas" ${ }^{29}$.

Não iremos adotar o tradicional ano de 1554 como sendo o da fundação de São Paulo. Não estamos tratando do Colégio e das ações dos jesuítas. Estamos analisando a administração municipal e, para que essa possa ser estudada, é necessário que partamos da data da instalação do município de São Paulo.

A data final da pesquisa, 1765, compreende momento de grandes mudanças em São Paulo. Nesse ano, a capitania de São Paulo foi restaurada, após 17 anos de incorporação à do Rio de Janeiro.

29 Afonso de Taunay. op. cit., p. 258. 
O novo governador, D. Luís Antônio de Souza Botelho Mourão, o Morgado de Mateus, inicia uma política de implementação de novas povoações na capitania. Isso porque, segundo Heloisa Bellotto, sabia o Morgado "o quanto a fixação da população seria útil para o desenvolvimento social e econômico da capitania"30.

Essa nova política de desenvolvimento da capitania marcou uma maior intervenção do governador em áreas que antes competiam às câmaras municipais. Até então, o controle das terras urbanas estava nas mãos das elites locais, as quais mantinham o acesso às propriedades conforme seus interesses.

A partir do momento em que o Morgado de Mateus funda novas vilas, na marinha e no planalto, garante a essas Câmara a propriedade de terras no termo. Equipara as câmaras tradicionais, isto é, as fundadas antes de 1765, com as de fundação posterior, por ação do governador.

Essa mudança no padrão de povoamento levou a um enfraquecimento do poder da Câmara de São Paulo, pois essa perdeu, assim como as demais vilas 'tradicionais' do planalto, o controle do acesso das populações à terra urbana.

Após apresentar as balizas cronológicas da pesquisa, é necessário que reflitamos sobre algumas questões importantes referentes á história de São Paulo.

O fato da vila de São Paulo tornar-se cidade e a capitania depois província e estado, ter o mesmo nome do município, levou a confusões na historiografia paulista.

A primeira separação que deve ser feita é entre o espaço local, isto é, o município, e o regional, capitania, província ou estado.

Conforme apontamos, a vila de São Paulo foi estabelecida em 1560 a partir da transferência do pelourinho de Santo André para o sítio próximo ao Colégio dos Jesuítas. A mudança à categoria de cidade se deu, conforme Azevedo Marques, "por uma carta régia de D. João V, datada de 11 de julho de 1711, ao tempo de seu primeiro governador e capitão-general Antônio de Albuquerque

30 Heloisa Bellotto. Autoridade e conflito no Brasil colonial. São Paulo: Alameda, 2007, p. 147. 
Coelho de Carvalho" ${ }^{31}$.

A divisão regional da colônia, como indicamos anteriormente, se deu por meio das capitanias hereditárias. A vila de São Paulo foi fundada em área da então capitania de São Vicente.

Essa, nas palavras de Azevedo Marques,

foi doada por D. João III a Martim Afonso de Sousa por alvará de 20 de janeiro de 1535 e tinha a extensão de 100 léguas ou 555,5 quilômetros de costa, divididos em duas partes: uma que começava do rio Santo Amaro para o Sul até 40 léguas ou 222,2 quilômetros que findavam 12 léguas ou 6,666 quilômetros, além de Cananéia; a outra que começava na foz do rio ou barra de Macaé e findava na barra do rio Juqueriquerê3 ${ }^{32}$.

Continua descrevendo que "assim permaneceu até que, sucedendo a guerra entre os paulistas e emboabas, pelos anos de 1708 e 1709, foi neste último, por carta de 3 de novembro, criada Capitania geral separada com o título de Capitania de São Paulo e Minas de Ouro" ${ }^{33}$.

Essa nova capitania, com o mesmo nome da cidade, seria "incorporada à coroa em 1710, com indenização aos donatários" ${ }^{34}$. Assim, passaria a capitania de donatarial, isto é, pertencente a donatários, à real, pertencente ao rei, que delegaria governadores e capitães-generais para administrá-la em seu nome.

A capitania de São Paulo foi incorporada à do Rio de Janeiro em $1748^{35}$. Foi restaurada em 6 de janeiro de 1765, com o nome de capitania de São Paulo, e administrada pelo Morgado de Mateus $^{36}$.

Em 1821, meses antes da Independência do Brasil, o sistema de capitanias foi formalmente extinto e a capitania de São Paulo passa a ser chamada de província. Com a Constituição

31 Manuel Eufrásio de Azevedo Marques. Apontamentos históricos, geográficos, biológicos, estatísticos e noticiosos da província de São Paulo. São Paulo: Martins, 1954, p. 241, vol. II.

32 Manuel Eufrásio de Azevedo Marques. op. cit., p. 167, vol. I.

33 Manuel Eufrásio de Azevedo Marques. op. cit., p. 168, vol. I.

34 Manuel Eufrásio de Azevedo Marques. op. cit., p. 167, vol. I.

35 Cf. Heloisa Bellotto. op. cit., p. 9.

36 Cf. Heloisa Bellotto. op. cit., p. 10. 
republicana de 1891, a província passaria a denominar-se estado de São Paulo ${ }^{37}$.

A presente dissertação divide-se em 3 capítulos. No primeiro, nos ocupamos em discutir a historiografia sobre São Paulo, administração colonial, urbanização e fontes do direito. Para tanto, abordamos a bibliografia mais relevante sobre os assuntos a fim de sustentar nossas interpretações posteriores.

No segundo capítulo apresentamos as fontes documentais que foram analisadas para o período estudado. Esboçamos uma discussão sobre como utilizá-las de forma quantitativa e qualitativa. Após essas ponderações, apresentamos o Banco de Dados e as variáveis que o compõe. A partir desse Banco de Dados mostramos os resultados obtidos desse a partir da análise estatística.

No terceiro capítulo discutimos os resultados do Banco de Dados frente ao problema central da pesquisa: o patrimonialismo e a concessão de terras urbanas. Para isso, realizamos a discussão em três partes: o poder local na América Portuguesa, consequências do poder local na urbanização de São Paulo e a criação de vilas no planalto serra-acima.

37 BRASIL. Constituição de 1891. Brasília: Senado Federal, 2001, art. 2. 


\section{Capítulo 1}

\section{A Construção do Objeto}

O estabelecimento de Piratininga, desde a era de 530, na borda do campo, significa uma vitória ganha sem combate sobre a mata, que reclamou alhures o esforço de várias gerações. Deste avanço procede o desenvolvimento peculiar de São Paulo. O Tietê corria perto; bastava seguir-lhe o curso para alcançar a bacia do Prata. Transpunha-se uma garganta fácil e encontrava-se o Paraíba, encaixado entre a serra do Mar e a Mantiqueira, apontando o caminho do norte. Para o sul estendiam-se vastos descampados, interrompidos por capões e até manchas de florestas, consideráveis, às vezes, mas incapazes de sustarem o movimento expansivo por sua descontinuidade.

João Capistrano de $\mathrm{Abreu}^{38}$

38 J. Capistrano de Abreu. Caminhos antigos e povoamento do Brasil. Brasília: Senado Federal, 2006, p. 107, [1 ${ }^{\mathrm{a}}$ edição, 1930]. 
Nesse capítulo iremos tratar da historiografia produzida sobre São Paulo, urbanização e terras urbanas, administração colonial e, consequentemente, fontes de direito. Demos o título de "A construção do objeto" por considerar que, antes de avançarmos nas hipóteses que norteiam o trabalho, é necessário fazer uma reflexão sobre a produção anterior sobre os temas abordados.

\section{1 - Historiografia sobre São Paulo}

Os primeiros estudos sobre São Paulo remontam à época colonial. Os trabalhos mais representativos são de Frei Gaspar da Madre de Deus e Pedro Taques de Almeida Paes Leme.

Ambos os autores pertenciam à Academias Históricas, instituições iluministas de intelectuais destacados. Íris Kantor afirma que a Academia dos Renascidos, da qual Frei Gaspar fez parte, tinha um programa historiográfico “orientado para a composição de memórias históricas, ou seja, para elaboração do que, nos termos atuais, poderíamos designar de instrumentos de pesquisa ou dissertações críticas"39.

Continua apresentando que “primeiro seriam preparadas as 'memórias históricas' em língua portuguesa para que, posteriormente, se escrevesse a 'história universal da América portuguesa' em língua latina" ${ }^{40}$.

Pedro Taques, em História da capitania de S. Vicente de 1772, logo no primeiro capítulo, afirma que o objetivo da obra é a

demonstração verídica e chronologica dos donatarios da capitania de S. Vicente, concedida a Martim Affonso de Sousa, primeiro donatario d'ella, desde o anno de 1531 até o de 1624, em que sua neta a Exma. Condeça de Vimieyro D. Marianna de Sousa da Guerra foi repellida da villa de Santos e

39 Íris Kantor. Esquecidos e renascidos: historiografia acadêmica luso-americana (1724-1759). São Paulo; Salvador: Hucitec; CEB-UFBA, 2004, p. 193.

40 Íris Kantor. op. cit., p. 193. 
S. Paulo pelo Exm. Conde de Monsanto D. Alvaro Pires de Castro ${ }^{41}$.

Para tanto, apresenta documentação que comprova a posse da capitania pela condessa de Vimieiro, como a doação a Martim Afonso, foral da capitania e provisão de Lopo de Souza.

A obra de Frei Gaspar, Memórias para a história da capitania de São Vicente, de 1797, deve ser compreendida, como apresenta Kantor, como um compêndio de informações sobre a história da capitania.

Em relação à fundação da vila de São Paulo, Frei Gaspar descreve, com base em cartas de jesuítas, "a História verdadeira da fundação da Cidade de S. Paulo, a qual não deve sua origem a Martim Afonso de Sousa"42. Rebate autores, como Charlevoix e Vaissette, que utilizaram, segundo Íris Kantor, "de notícias falsas e difusão de fábulas"43.

Em 1920 Afonso de Escragnolle Taunay publica S. Paulo nos primeiros anos e, um ano depois, S. Paulo no século XVI. Com essas obras, de acordo com Laima Mesgravis, "é que se iniciou o estudo sistemático de diversos temas fundamentais para o conhecimento de História de São Paulo"44.

Na primeira obra, Taunay propõe um “ensaio de reconstituição social”, no qual apresenta aspectos cotidianos da vida na vila, graças aos "informes e pormenores sobre a vida das primeiras gerações piratininganas" ${ }^{45}$, coletados nas Atas da Câmara.

Apresenta, de maneira geral, como "pitoresca a contraposição da sua vida quinhentista, tão rudimentar, e da existência da capital opulenta hodierna, cheia da convicção da magnitude do porvir que se antolha, e orgulhosa da progressão geométrica de sua grandeza" ${ }^{46}$.

A pobreza da vila seria compensada pela ideia do espírito de independência municipal.

41 Pedro Taques de Almeida Paes Leme. História da capitania de São Vicente. São Paulo: Melhoramentos, $195-$, p. 61.

42 Frei Gaspar da Madre de Deus. Memórias para a capitania de São Vicente, hoje chamada de São Paulo. São

Paulo: Martins, 1953, p. 126.

43 Íris Kantor. op. cit., p. 242.

44 Laima Mesgravis. Introdução. In TAUNAY, Afonso de. São Paulo nos primeiros anos e São Paulo no século XVI. São Paulo: Paz e Terra, 2003, p. 3.

45 Afonso de Taunay. op. cit., p. 20.

46 Afonso de Taunay. op. cit., p. 16. 
Taunay afirma que "já por vezes notamos a atitude independente das câmaras paulistanas quinhentistas. Ciosas de seus direitos e prerrogativas, frequentemente, no decorrer do século XVI, fizeram frente à prepotência de capitães-mores e ouvidores"47.

A segunda obra, São Paulo no século XVI, de 1921, apresenta características distintas da primeira. Ao invés de narrar o cotidiano do município, através das Atas da Câmara e cartas de jesuítas, o autor propõe escrever uma história factual de São Paulo.

Para tanto, inicia com a narração da fundação da vila, enfatizando a importância dos jesuítas. Descreve os embates iniciais com os índios e dedica boa parte da obra aos anos iniciais das bandeiras.

Em sua obra, destaca-se a contribuição da valorização da figura do bandeirante à história de São Paulo, consolidada em 1924 com o início da publicação da obra monumental História geral das bandeiras paulistas.

Nessa obra pretende "acompanhar-lhe os passos, desde os primeiros prodromos, consagraremos uma série de capitulos á exposição das condições em que nasceu e evoluiu, e ao estudo do ambiente americano-brasileiro, em que veio a actuar de modo tão enérgico, transformando por completo a geographia do continente meridional, em detrimento do dominio hespanhol"48.

Apresenta as bandeiras como "episodio culminante dos annaes brasileiros, pois a elle deve o paiz dois terços do seu territorio actual, foi no emtanto o bandeirantismo até quase os dias modernos tratado com grande descaso"49. Propõe, ao realizar tamanha obra, fazê-la "por um pendor especial do espírito a reverenciar a obra destes construtores épicos do Brasil central e meridional, que aos historiadores estrangeiros arrancaram arroubadas expressões de admiração" ${ }^{50}$.

Apesar do empenho de Taunay em construir uma identidade paulista, é com Raça de

47 Afonso de Taunay. op. cit., p. 78.

48 Afonso deTaunay. História geral das bandeiras paulistas. Typ. Ideal, 1924, p. 20, vol. I.

49 Afonso de Taunay. op. cit., p. 7, vol. I.

50 Afonso de Taunay. op. cit., p. 15, vol. I. 
gigantes, de Alfredo Ellis Jr, que a imagem do bandeirante como ícone do passado é consolidada.

Ambos, Taunay e Ellis lecionaram na recém criada Universidade de São Paulo. No entanto, Ellis foi que mais tempo ocupou a Cadeira de História da Civilização Brasileira ${ }^{51}$, criando discípulos que deram continuidade às suas pesquisas.

Propõe Alfredo Ellis Jr., em sua obra, analisar a formação racial do paulista e, posteriormente, fazer uma análise psicológica. Afirma que “dessa lucta homerica pela vida, na qual entraram desprovidos de todas as condições para vencer, a não ser o animo forte, originou-se a bellicosidade paulista, amparada pelo habito constante da refrega e por um continuo trabalhar" ${ }^{52}$.

A análise idealizada da história de São Paulo é reforçada ao escrever que "a honradez foi onde se sublinhou o caracter paulista" ${ }^{53}$ apesar da "crueldade, rudeza e selvageria" ${ }^{54}$.

Em 1929 Alcantâra Machado publica Vida e morte do bandeirante. Apesar de não criticar a construção da figura do bandeirante, adota postura diferenciada dos autores anteriores ao afirmar que "reduzir o estudo do passado à biografia dos homens ilustres e à narrativa dos feitos retumbantes seria absurdo tão desmedido como circunscrever a geografia ao estudo das montanhas"

Propõe apresentar o cotidiano dos habitantes de São Paulo, descrevendo-os através da consulta aos inventários e testamentos.

Contesta autores, como Alfredo Ellis Jr., que afirmam ter havido fortunas coloniais. Alcântara Machado rebate concluindo que "a prova direta e cabal, encontramo-la nos inventários trazidos a público, testemunhas fidedignas da modéstia dos espólios" ${ }^{56}$.

Apresenta, a partir dos inventários, uma descrição preciosa da casa paulista. Descreve "salas imensas, em cuja vastidão se encolhem e somem os móveis destinados a guarnecê-las. Nenhum

51 Maria H. Rolim Capelato, Raquel Glezer e Vera L. Amaral Ferlini. Escola uspiana de história. Estudos avançados. São Paulo, n. 8 (22), 1994, p. 357-358

52 Alfredo Ellis Jr. Raça de gigantes. São Paulo: Helios, 1926, p. 242.

53 Alfredo Ellis Jr. op. cit., p. 250.

54 Alfredo Ellis Jr. op. cit., p. 249.

55 Alcântara Machado. Vida e morte do bandeirante. São Paulo: Martins, 1943 p. 17.

56 Alcântara Machado. op. cit., p. 28. 
desses mil e um objetos de ornamentação ou utilidade que em nossos dias põem uma nota de beleza ou bem estar nas habitações mais humildes. Nenhum painel a romper a monotonia das paredes nuas" ${ }^{97}$.

Em 1956 Washington Luis publica Na capitania de São Vicente. Na introdução da obra afirma que

a história colonial paulista tem sido feita a vista de crônicas religiosas, de algumas cartas jesuíticas, dispersas e truncadas cronologicamente, a vista de conscienciosas informações da Nobiliarquia de Pedro Taques, dos verídicos Apontamentos de Azevedo Marques, das Memórias inteligentes de Frei Gaspar, da contribuição valiosa de alguns outros escritores, e de tradições, que necessitem crítica justa e imparcial, quando não se encontrem documentos que as comprovem" 58 .

Documentos publicados, como as Atas da Câmara, Registro Geral, Inventários e Testamentos e Documentos Interessantes, levaram o autor a rever as obras sobre história de São Paulo e "de novo estudando-as, e agora em farta e novas publicações e de novos e alheios estudos, mais se me fixou o meu modo de pensar sobre alguns pontos, não obstante se por vezes contrário às brilhantes e sedutoras deduções que outros conscienciosamente têm feito" ${ }^{59}$.

Apesar da nova documentação disponível, Washington Luís segue em sua obra com a narrativa tradicional. Inicia abordando as navegações portuguesas, a fundação das vilas e dedica boa parte do livro à narração das entradas ao sertão, enfatizando a descrição dos bandeirantes mais destacados.

A obra Formação histórica de São Paulo, de Richard Morse, publicada em 1954, representa uma mudança de perspectiva na historiografia paulista.

Primeiramente, trata-se de um autor norte-americano que aborda a urbanização latino-

57 Alcântara Machado. op. cit.,p. 61.

58 Washington Luís Pereira de Sousa. Na capitania de São Vicente. São Paulo: Martins, 1956 p. VII.

59 Washington Luís Pereira de Sousa. op. cit.,.p. XII. 
americana, elegendo "São Paulo por representar de maneira mais dramática o que se chamou de estádio ‘centrípeto’ do desenvolvimento urbano da América Latina" ${ }^{60}$.

Foca seu estudo no período da Independência, por representar o momento em que a cidade era uma comunidade em oposição à metrópole que se tornaria no século XX.

Devido a esse enfoque, há poucas páginas sobre o período colonial. Porém, convém destacar a interpretação de Morse sobre o povoamento do planalto, ao afirmar que esse "teve um caráter misto, urbano-rural. Como forças centrífugas atuando sobre o núcleo urbano, havia as grandes extensões de terras gratuitas, a natureza extensiva da pecuária e da agricultura praticadas, os trabalhadores índios em cada latifúndio, servindo como tropa de defesa. São Paulo tornou-se um apêndice do campo" ${ }^{\prime 1}$.

Apesar do comércio paulista, “o planalto estava longe de ser um empório comercial e a sua base econômica era essencialmente a agricultura de subsistência" ${ }^{62}$.

Acrescenta à penúria as motivações psicológicas e culturais para compreender o fenômeno das bandeiras. Conclui que "uma série de outros fatores, étnicos, culturais e psicológicos poderiam ser aduzidos, entre os quais a visão edênica, tão cuidadosamente estudada por Sérgio Buarque de Holanda e incorporada de modo persistente no lendário dos bandeirantes"63.

Não desenvolve Morse o capítulo sobre a Colônia para dedicar-se mais ao Império e República. Afirma que “o tamanho pequeno e a aparência rústica de São Paulo em todo o período colonial, longe de refletirem uma contribuição sem importância para o desenvolvimento nacional, exprimem uma multiplicidade de funções e imperativos, que canalizavam continuamente as suas energias excepcionais para a hinterlândia paulista e as regiões distantes do Brasil inteiro" ${ }^{64}$.

Em 1986, Katia M. Abud defende a tese Sangue intimorato e as nobilíssimas tradições: a contribuição de um símbolo paulista: o bandeirante, na qual propõe estudar o bandeirante como

60 Richard Morse. Formação histórica de São Paulo (de comunidade à metrópole). São Paulo: Difel, 1970, p. 19.

61 Richard Morse. op. cit., p. 30.

62 Richard Morse. op. cit., p. 33.

63 Richard Morse. op. cit., p. 34.

64 Richard Morse. op. cit., p. 38. 
base da identidade paulista.

A esse respeito conclui Abud que "mais fortes em uns, mais fracos em outros as linhas do contorno bandeirista reapareceram [no século XX] para simbolizar não só uma elite política mas também para justificar a predominância dessa elite sobre todo o Brasil, identificando o Estado à Nação"

Em 1992 Raquel Glezer apresenta a tese de livre-docência intitulada Chão de terra: um estudo sobre São Paulo colonial. Nessa obra, pretende compreender a terra urbana e suas características. Afirma que "nos estudos de urbanização há um tema inexplorado e que despertou minha atenção quando retomei projetos e leituras: a propriedade do terreno urbano, a terra urbana"

Tal estudo, juntamente com a tese de Katia Abud, realizou uma abordagem crítica sobre a história de São Paulo e, com, isso, permitiu a adoção de temas distintos dos da historiografia tradicional, marcada por trabalhos sobre bandeiras, níveis de riqueza ou pobreza e a construção de uma identidade paulista.

Seguindo essa nova perspectiva de estudos, John Monteiro publica, em 1994, Negros da terra: indios e bandeirantes nas origens de São Paulo. Apesar de retomar temática já consagrada, o autor destaca-se por tratar do tema de maneira diferente da usual.

Apresenta que o ponto de partida da pesquisa

$$
\begin{aligned}
& \text { é a simples constatação de que as frequentes incursões ao interior, em vez de } \\
& \text { abastecerem um suposto mercado de escravos índios no litoral, alimentavam } \\
& \text { uma crescente força de trabalho indígena no planalto, possibilitando a } \\
& \text { produção e o transporte de excedentes agrícolas; assim, articulava-se a região } \\
& \text { da chamada Serra-Acima a outras partes da colônia portuguesa e mesmo ao }
\end{aligned}
$$

65 Katia M. Abud. Sangue intimorato e as nobilíssimas tradições: a contribuição de um símbolo paulista: o bandeirante. São Paulo, 1986, Tese de doutorado (História Social) - Faculdade de Filosofia, Letras e Ciências Humanas, Universidade de São Paulo, p. 132-133.

66 Raquel Glezer. Chão de terra e outros estudos sobre São Paulo. São Paulo: Alameda, 2007, p. 54. 
circuito mercantil do Atlântico Meridional ${ }^{67}$.

Propõe uma abordagem mais crítica em relação à escravidão indígena, focando seu estudo nas relações dos colonos e populações nativas, superando a oposição entre paulistas e jesuítas, tradicional questão da historiografia paulista.

Em 1995 Ilana Blaj defende a tese Trama das tensões: o processo de mercantilização de São Paulo colonial (1681-1721) em que constesta a "pobreza, isolamento, autonomia, rebeldia, uma tendência maior à democracia, mas sempre uma 'nobreza guerreira', [e que] são algumas visões sobre São Paulo colonial até fins do XVII que foram tipificadas, entrecruzadas e cristalizadas" ${ }^{\text {. }}$.

A partir dessa crítica, Ilana apresenta seu objeto central de análise: "trata-se de privilegiar a vila de São Paulo entre 1681 e 1721, sua dinâmica interna, acompanhando os processos concomitantes de fixação na dispersão e de mercantilização além de discutir as tensões sociais daí decorrentes e a ação da elite, tanto a nível interno quanto em sua relação com a própria metrópole" ${ }^{\oplus 9}$.

\section{2 - Historiografia sobre Urbanização}

A história da urbanização teve como obra inaugural no Brasil o capítulo "O Semeador e o Ladrilhador", presente na segunda edição de Raizes do Brasil, de Sérgio Buarque de Holanda. Publicado em 1947, apresenta a comparação entre a estrutura urbana aplicada nas Américas espanhola e portuguesa, diferença essa que tornou-se clássica e presente nos estudos sobre cidades brasileiras.

Para o autor, a cidade da América espanhola foi estruturada em formato de grelha, com

67 John Monteiro. Negros da terra: índios e bandeirantes nas origens de São Paulo. São Paulo: Companhia das Letras, 1994, p. 8. Tradução da tese São Paulo in the Seventeenth Century: economy and society, defendida em 1985.

68 Ilana Blaj. Trama das tensões: o processo de mercantilização de São Paulo colonial (1681-1721).,São Paulo, 1995, Tese de doutorado (História Social) - Faculdade de Filosofia, Letras e Ciências Humanas, Universidade de São Paulo, p. 14. Editado em 2002.

69 Ilana Blaj. op. cit., p. 18. 
quadras regulares e praça-maior como centro administrativo definido, segundo os padrões das cidades planejadas durante o Renascimento.

Segundo Leonardo Benevolo, essas

novas cidades seguem um modelo uniforme: um tabuleiro de ruas retilíneas, que definem uma série de quarteirões iguais, quase sempre quadrados; no centro da cidade, suprimindo ou reduzindo alguns quarteirões, consegue-se uma praça, sobre a qual se debruçam os edifícios mais importantes: a igreja, o paço municipal, as casas dos mercadores e dos colonos mais ricos. ${ }^{70}$

Para a cidade luso-americana,

a rotina e não a razão abstrata foi o princípio que norteou os portugueses, nesta como em tantas outras expressões de sua atividade colonizadora. Preferiam agir por experiência sucessivas, nem sempre coordenadas umas às outras, a traçar de antemão um plano para segui-lo até o fim. Raros os estabelecimentos fundados por eles no Brasil que não tenham mudado, uma, duas ou mais vezes de sítio, e a presença da clássica vila velha ao lado de certos centros urbanos de origem colonial é persistente testemunho dessa atitude tateante e perdulária. ${ }^{71}$

Ao analisar a estrutura urbana aplicada na América portuguesa, Sérgio Buarque define que “a cidade que os portugueses construíram na América não é produto mental, não chega a contradizer o quadro da natureza, e a silhueta se enlaça na linha da paisagem. Nenhum rigor, nenhum método, nenhuma previdência, sempre esse significativo abandono que exprime a palavra 'desleixo'"72.

Recentemente, Amílcar Torrão Filho, na obra Paradigma do caos ou cidade da conversão?, de 2007, apresenta um panorama da historiografia sobre história da urbanização. Afirma que

70 Leonardo Benevolo. História da cidade. São Paulo: Perspectiva, 1993, p. 487.

71 Sérgio Buarque de Holanda. Raizes do Brasil. São Paulo: Companhia das Letras, 2003, p. 109 [2ª edição 1947].

72 Sérgio Buarque de Holanda. op. cit., p. 110. 
o "semeador e o ladrilhador" funda a interpretação da cidade colonial na América portuguesa. Dizemos que funda a interpretação e não uma interpretação específica porque todas as seis 'teses' que apresentaremos a seguir são, em sua maior ou menor grau, tributárias deste texto iniciático, e a ele se referem, mesmo quando não o citam diretamente. ${ }^{73}$

A primeira tese é a da “desordem e do desleixo", representada pelas obras de Aroldo de Azevedo e Nelson Omegna. Azevedo, em seu livro Vilas e Cidades no Brasil Colonial, de 1956, apresenta uma síntese do modelo de ocupação urbano no Brasil. Nos primeiros séculos da ocupação portuguesa, ressalta que a principal motivação para a fundação de vilas e cidades na colônia se deu por questões estratégicas. Para o autor, "no panorama urbano do Brasil seiscentista, a cidade de Salvador brilhava, sem nenhuma dúvida, não encontrando outro centro que lhe fizesse sombra" 74 , isso porque figurava como centro da administração colonial. Com isso, apresenta, mesmo que indiretamente, uma possível tentativa de compreender as diferenças entre as cidades brasileiras e as demais hispano-americanas.

Em relação à ocupação espacial, Azevedo assinala a preferência por áreas elevadas para o sítio urbano, reforçando a interpretação da necessidade defensiva desses núcleos. Os cursos d'água também foram determinantes para a ocupação, devido à necessidade desses para a sobrevivência de um aglomerado urbano. Caracteriza, portanto, que as cidades coloniais portuguesas não buscavam o planejamento urbano, mas sim a sua sobrevivência frente à situações hostis.

Nelson Omegna, em 1961, publica A cidade colonial. Nessa obra, defende, tal como Aroldo de Azevedo, a intepretação de que o povoamento colonial foi marcado pela desordem e desleixo. Afirma que "a pobreza e pequenez das vilas coloniais deram-lhe um outro papel importante: a atribuição a maior número de pessoas, distribuídas por camadas sociais mais diversas, e por mais ampla área geográfica, das tarefas de governo e do trato dos interesses públicos"75.

73 Amílcar Torrão Filho. Paradigma do caos ou cidade da conversão?. São Paulo: FAPESP; Annablume, 2007, p. 47.

74 Aroldo de Azevedo. Vilas e cidades do Brasil colonial. São Paulo: FFLC-USP, 1956, p. 29.

75 Nelson Omegna. A cidade colonial. Rio de Janeiro: J. Olympio, 1961, p. 37. 
Conclui que a predominância do meio rural frente ao urbano, marcado pela pobreza das vilas no período colonial, faz com que as cidades, "situadas no centro de largas zonas rurais, entregues ao mando e os desmandos dos potentados individualistas das fazendas ou dos engenhos, convocam as pequenas vilas as populações para os cuidados da coisa pública, incutindo-lhes lições e despertando-lhes a consciência política" ${ }^{\text {" }}$. Deve-se, portanto, a predominância do caráter rural à incapacidade do português em criar cidades, delegando essas à ação do acaso.

A "tese da ordem pragmática" é "aquela parte da historiografia que procurou rever a noção de desordem e desleixo da tese anterior, que reconhece diferenças, às vezes não tão substanciais entre as cidades portuguesas e espanholas da América, e mesmo da Ásia e da África, e que reconhece ao menos algum tipo de ordenamento urbano nestas cidades" ${ }^{\text {"77 }}$.

Segundo Torrão Filho, essa categoria é composta, principalmente, pela interpretação de Mário Chicó e Nestor Goulart Reis Filho. Ao tratar das vilas e fortificações portuguesas no Estado da Índia, Chicó afirma que a urbanização se deu seguindo os padrões da estratégia militar e aponta que o traçado muitas vezes irregular das vilas portuguesas se deu mais por adaptação ao terreno e falta de recursos, e não a um desleixo característico da ação do conquistador português.

Nestor Goulart Reis Filho, em Contribuição ao estudo da evolução urbana no Brasil, de 1968, apresenta a ideia que Portugal fundou vilas ao longo do litoral da América portuguesa, formando uma rede urbana com evidente funções defensivas e econômicas. Agiu, portanto, de forma racional, ao contrário do que define Sérgio Buarque. Em relação ao traçado urbano, Nestor Goulart apresenta que "no conjunto porém a regularidade do traçado estava, até o início do século XVIII, quase ausente do Brasil. Ainda que por muitas vezes, no começo, as ruas fossem alinhadas, havia pequena preocupação de manter as diretrizes iniciais, cuja importância ia ficando

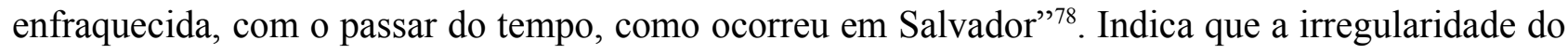

76 Nelson Omegna. op. cit., p. 38.

77 Amílcar Torrão Filho. op. cit., p. 56.

78 Nestor Goulart Reis Filho. Contribuição ao estudo da evolução urbana no Brasil. São Paulo: Pioneira, 1968, p. 131. 
traçado das vilas e cidades não está relacionada com o projeto urbano, mas sim com problemas de fiscalização e administração dos municípios.

Em obra mais recente, de 2004, Nestor Goulart mantém essa interpretação. Em São Paulo vila cidade metrópole, descreve o processo de crescimento urbano da vila, de sua fundação até aos dias atuais, enfatizando as descrições das transformações espaciais da estrutura urbana. Aponta que “a referência básica para o traçado das ruas era o conjunto dos caminhos das águas. (...) Outra referência é fornecida pelo caminho das águas das chuvas. Como bem sabem os pedreiros as casas não devem ser construídas sobre os caminhos de passagem das águas pluviais. (...) Os caminhos das águas eram deixados livres, em ruas e becos que facilitassem sua passagem". Ou seja, afirma que houve um certo planejamento na construção das vilas e cidades portuguesas, exemplificando com a vila de São Paulo, opondo-se, dessa forma, à interpretação de "desleixo" apresentada por Sérgio Buarque.

A terceira tese corresponde à interpretação da "cidade como construtora da nacionalidade". Representa essa categoria a obra de Plínio Salgado $^{79}$, em que aponta o período colonial como momento de formação da nacionalidade brasileira, em analogia ao papel que a Idade Média teve na construção da identidade das nações europeias.

Em relação à obra de Plínio Salgado, Torrão Filho conclui que,

assim, por meio das cidades, os portugueses afirmam o primado da Fé, da cristandade, acima dos interesses materiais que tinham em outros pontos do globo, onde não havia uma população vivendo em uma 'natureza edênica', sem pecados e pronta para receber os recebimentos de Cristo. Ao contrário de Sérgio Buarque, as raízes que Plínio Salgado vê em nosso passado português são urbanas, ordenadas, em sentido cósmico, e base da boa nacionalidade pois fundada na fé. ${ }^{80}$

79 Plínio Salgado. Como nasceram as cidades no Brasil?. São Paulo: Voz do Oeste, 1978.

80 Amílcar Torrão Filho. op. cit., p. 69. 
A quarta tese apresentada por Torrão Filho é a da "organicidade medieval". Para os autores dessa categoria, "parte da desqualificação da cidade portuguesa justifica-se por sua suposta origem medieval, pela preferência indiscriminada pela irregularidade das ruas, pelos becos e azinhagas, pelos terrenos altos e de topografia disforme" $"$.

O principal autor dessa interpretação é Paulo Santos. Em Formação de cidades no Brasil colonial apresenta semelhanças entre as cidades da América portuguesa com as similares medievais. As similaridades são representadas pelo absolutismo do rei em oposição ao Concelho "que já traduzia um anseio de vontade coletiva municipal [e a Igreja] como fator de aglutinação, o instinto de defesa e as corporações de ofício" ${ }^{2}$.

Segundo Torrão Filho, "Paulo Santos não busca nestas cidades iniciais uma suposta regularidade que as redimam na história do urbanismo, mas o que as torna interessantes e importantes é esta irregularidade que não é resultado do desleixo ou da improvisação, mas de uma organicidade, de uma relação do homem com a cidade, que vai além do racional, do planejamento e do controle" 83 .

A quinta interpretação corresponde à tese da "espacialidade barroca". Segundo Torrão Filho, esta "questiona a tese da desordem, negando que essa especialidade seja espontânea ou caótica, embora mantenha ainda a comparação com a cidade espanhola na América. Também se opõe à tese da organicidade medieval, negando esta suposta origem da cidade portuguesa na América" 84 .

A obra de Giovanna Del Brena representa essa interpretação. Defende que é necessária “uma leitura em chave barroca da cena urbana colonial no Brasil" ${ }^{\prime 5}$. Nas cidades luso-brasileiras, temos escolhas urbanísticas que "apesar de estas nunca terem sempre apresentadas - de acordo com o

81 Amílcar Torrão Filho. op. cit., p. 69.

82 Paulo Santos. Formação de cidades no Brasil colonial. Rio de Janeiro: EdUFRJ, 2001, p. 21.

83 Amílcar Torrão Filho. op. cit., p. 74.

84 Amílcar Torrão Filho. op. cit., p. 72.

85 Giovanna Del Brena. Medieval ou barroco? Proposta de leitura do espaço urbano colonial. Barroco. Belo Horizonte, n. 12, 1982-1983, p. 144. 
secular pragmatismo português - como soluções para problemas específicos" ${ }^{\circledR 6}$.

A sexta e última interpretação sobre a historiografia da urbanização brasileira corresponde à "tese da cidade como elemento de ordenamento civil e eclesiástico". Essa, "em sua maioria, não chega a negar totalmente a tese da desordem e do desleixo do ponto de vista urbanístico, mas revela a importância que as cidades tinham do ponto de vista administrativo e religioso" ${ }^{97}$.

Richard Morse, apresentado como principal representante dessa interpretação, afirma que, na América portuguesa a cidade é instalada por meios políticos, antecedendo às necessidades econômicas, ao contrário da Europa, em que o estatuto das cidades derivava quase sempre "da localização estratégica no cruzamento de duas ou mais rotas de comércio revitalizado"88.

Murillo Marx, em Cidade brasileira, de 1980, reitera a diferença entre as cidades portuguesas e hispano-americanas. Afirma "que o contraste entre o urbanismo tradicional do Brasil e o praticado nas três Américas é gritante" ${ }^{" 89}$. Porém, vai além da constatação das diferenças espaciais, principalmente sobre as praças resultantes das duas colonizações ibéricas. Os núcleos urbanos dos portugueses tinham como ponto central o adro da igreja, determinando o espaço com a função religiosa. Diferenciamente dos núcleos hispano-americanos, nos quais as praças centrais tinham, além da função religiosa, importante função político-administrativa.

Essa importante observação foi melhor estruturada em Nosso chão: do sagrado ao profano, publicada em 1989. De maneira geral, conclui que "a maneira como se deu e formalizou a união da Mitra com a Coroa torna-se expressa em muitas das peculiaridades da conformação urbanística de nossos aglomerados humanos e, particularmente, nas características de seus espaços públicos" ${ }^{” 0}$. Com isso, aponta para uma característica importante da organização administrativa do Império

86 Giovanna Del Brena. Projetos urbanos no Rio de Janeiro em meados do século XVIII. Lisboa iluminista e o seu tempo. Actas de colóquio, 26, 27 e 28 de outubro de 1994. Lisboa: Universidade Autónoma de Lisboa, 1994, p. 275.

87 Amílcar Torrão Filho. op. cit., p. 74.

88 Richard Morse. A evolução das cidades latino-americanas. Cadernos Cebrap. São Paulo: Brasiliense, 22, 1975, p. 11-12.

89 Murillo Marx. Cidade brasileira. São Paulo: Melhoramentos, 1980, p. 50.

90 Murillo Marx. Nosso chão: do sagrado ao profano. São Paulo: EdUSP, 1989, p. 21. 
Português, a união entre Estado e Igreja, principalmente no que diz respeito à legislação urbanístic, separação que ocorre só com o advento da República em 1889.

Maria Fernanda Bicalho, em A cidade e o Império, de 2003, difere da posição de Sérgio Buarque em relação ao suposto "desleixo" com que os portugueses trataram suas cidades coloniais. "É provavelmente unânime a concordância dos estudiosos acerca da forte presença do Estado português na aventura ultramarina. Menos consensual seria a afirmação da presença tutelar do Estado na política urbanizadora dos territórios coloniais" ${ }^{\text {"1 }}$. Dessa forma, argumenta que não houve uma falta de preocupação da Coroa portuguesa com as vilas e cidades coloniais, mas uma preocupação diferente da Coroa de Castela. Conclui a discussão afirmando que "se a Coroa espanhola forneceu às suas colônias um regulamento para a formação de cidades, a Coroa portuguesa forneceu às suas funcionários que as fizessem. Funcionários de urbanismo, como havia da fazenda, justiça ou da religião"’2.

Bicalho argumenta que "o controle a regulamentação do espaço urbano constituíam um indiscutível mecanismo de poder, ferrenhamente disputado pelos representantes dos poderes local e metropolitano"93. Essa afirmação nos mostra que, tal como assinala Murillo Marx em relação à importância do aspecto religioso na urbanização, é fundamental a preocupação com o poder político, tanto geral como local.

Em 1992, Raquel Glezer defende a tese de livre-docência denominada Chão de terra: um estudo sobre São Paulo colonial, publicada em 2007. Nessa obra, discute o processo de urbanização da vila e cidade de São Paulo através do enfoque da propriedade territorial. Para tanto, defende a ideia de separação entre terra urbana, representada pelas datas de terra da rural, pelas sesmarias.

Seguindo a interpretação da "cidade como elemento de ordenamento civil e eclesiástico", nas linhas de Murillo Marx, Raquel Glezer apresenta que, "na busca de compreender o processo que

91 Maria Fernanda B. Bicalho. A cidade e o Império. Rio de Janeiro: Civilização Brasileira, 2003, p. 174.

93 Maria Fernanda B. Bicalho. op. cit., p. 202. 
levou à diferenciação da terra urbana retomei a bibliografia [sobre organização administrativa] e legislação portuguesa"94.

Portanto, para seguirmos a diferenciação de terra urbana, objeto dessa pesquisa, torna-se necessário abordar a historiografia sobre administração colonial e local e, em seguida, uma reflexão sobre as fontes escritas do Direito, isto é, as legislações que regulavam as relações no território luso-americano.

\section{3 - Historiografia sobre Administração Colonial}

A História Administrativa do Brasil, de Max Fleiuss, foi o primeiro esforço de reunir em uma obra reflexões sobre a administração colonial. Publicada em 1923, propõe abordar a organização administrativa na Colônia, Reino Unido e Império, mas acaba por enfatizar o período posterior à Independência, principalmente o reinado de D. Pedro II.

A obra de Max Fleiuss, membro do Instituto Histórico e Geográfico Brasileiro, pode ser considerada um primeiro esforço mais especializado após obras abrangentes, como a História Geral do Brasil ${ }^{95}$. Utiliza a bibliografia disponível para a época, ou seja, estudos históricos amplos e descritivos, construídos com a intenção de formular uma História Nacional, como Varnhagen e Capistrano de Abreu, por exemplo.

Inicia o período colonial descrevendo ações dos capitães-generais e governadores, em uma clara escolha de exaltação. Ao tratar da fundação do primeiro município em terras coloniais, Fleiuss relata que

ao fundar S. Vicente, dizem os nossos historiadores, Martim Affonso demarcou, primeiro, e arruou o terreno, distribuiu-o em lotes aos sesmeiros, edificou as casas necessárias, levantou um forte, a casa da Câmara, a cadeia, 
a egreja, a alfandega; nomeou officiais para administrar a justiça e convocou os homens bons para procederem á eleição dos vereadores; installou, assim, o nosso primeiro nucleo civil de administração colonial. ${ }^{96}$

E, em relação aos poderes coloniais, concluiu que "o capitão-mór, como o governador, era realmente um representante do monarcha, com autoridade ampla e grandes privilegios, regulados pelas cartas de donataria e foraes." ${ }^{\text {97 }}$. Seguindo a linha que havia traçado para Martim Afonso, exalta a figura de Tomé de Sousa, afirmando que esse "foi o verdadeiro fundador e organizador da política lusitana nesta parte do Novo Mundo" ${ }^{98}$.

A história da administração colonial apresentada por Max Fleiuss é composta por uma série de descrições de ações de governadores, ignorando os poderes locais representados pelas câmaras municipais. Em relação à essas, dedica poucas linhas, relatando que “ás camaras de então competiam funcções muito mais amplas que ás actuaes municipalidades" ${ }^{99}$.

É interessante notar que o posicionamento do autor em relação aos municípios é diferente de João Laxe, que em 1885 escreve um histórico das câmaras municipais coloniais, defendendo a volta dos poderes amplos que essas tinham antes de $1828^{100}$.

Dedica boa parte de seu livro ao período posterior à Independência e o maior capítulo ao reinado de D. Pedro II, descrevendo a formação, contexto político e ações dos 36 gabinetes ocorridos no período. Exalta-o como o grande estadista e defende que o centenário da Independência seja um momento de resgate da figura do Imperador, desgastada e não reconhecida por uma historiografia republicana, preocupada em garantir legitimidade para o novo regime.

A História Administrativa do Brasil, de Max Fleiuss, tem como característica marcante o projeto de resgate da figura política de D. Pedro II. Devido a seu caráter abrangente e pelo fato de ser a primeira obra que aborda de forma sistemática, as questões da administração pública, 96 Max Fleiuss. História Administrativa do Brasil. São Paulo: Melhoramentos, 1922, p. 7.

97 Max Fleiuss. op. cit., p. 13.

98 Max Fleiuss. op. cit., p. 29.

99 Max Fleiuss. op. cit., p. 43.

100 João Baptista C. Laxe. Câmaras municipais (histórico). Rio de Janeiro: B. L. Garnier, 1885. 
influenciou as pesquisas posteriores na área e iniciou uma tradição de utilização da História Administrativa como veículo para exaltação de figuras políticas.

Em 1942, Caio Prado Jr. publica a Formação do Brasil Contemporâneo, com o objetivo central de buscar um sentido para a colonização e a compreensão da situação do país através de sua formação histórica. Adotando uma abordagem marxista, enfatiza as relações comerciais e suas relações com as vias de transporte e com a organização social e política.

Quanto à administração colonial, dedica um capítulo inteiro à questão. Inicia fazendo uma ressalva, afirmando que "a administração colonial nada ou muito pouco apresenta daquela uniformidade e simetria que estamos hoje acostumados a ver nas administrações contemporâneas." ${ }^{101}$. Apesar de apresentar a diferenciação entre o período em que escreve e o objeto estudado, não pondera sobre as especificidades da administração colonial. Alerta que "devemos abordar a análise da administração colonial com o espírito preparado para toda sorte de incongruências" 102 e que o fato de "centralizar o poder e concentrar as autoridades; reuni-las todas nas capitais e sedes, deixando o resto do território praticamente desgovernado e a centenas de léguas muitas vezes da autoridade mais próxima"103.

As críticas à administração colonial não se resumem às incongruências. Para Caio Prado, o problema está na estrutura do sistema político, tanto é que para sua análise da administração colonial conclui que "no sistema administrativo da colônia (...) não existiam administrações distintas e paralelas, cada uma com esfera própria de atribuições: uma geral, outra local" ${ }^{104}$. Como consequência desse sistema, somado com a estrutura econômica da colônia, Caio Prado afirma que “o primeiro traço é de esperar, e que de fato não falhará à expectativa, é a ausência de nexo moral" 105 por parte da população colonial. Isto é, a administração colonial seria marcada pela total falta de lógica e racionalidade.

101 Caio Prado Jr. Formação do Brasil Contemporâneo. São Paulo: Brasiliense, 1942, p. 300.

102 Caio Prado Jr. op. cit., p, 301.

103 Caio Prado Jr. op. cit., p. 302.

104 Caio Prado Jr. op. cit., p. 314.

105 Caio Prado Jr. op. cit., p. 341. 
A visão de Caio Prado em relação à administração colonial é negativa. O período colonial foi compreendido como a origem dos males que assolam o Brasil contemporâneo. Se a estrutura econômica colonial de exploração comercial foi a responsável pelos problemas contemporâneos, a administração, apresentada pelo autor como consequência dos interesses econômicos, foi vista como caótica, retrógrada e incongruente. O passado administrativo passou a ter uma utilização oposta à de Max Fleiuss. Ao invés da exaltação de figuras políticas, a história administrativa retratou o passado como algo ultrapassado ao legitimar uma ação de mudança das estruturas políticas do país.

Raimundo Faoro aborda a administração colonial em uma outra perspectiva. Em Os Donos do Poder, de 1958, adota uma interpretação weberiana da estrutura política brasileira, tendo como objetivo principal a compreensão do processo de formação do que classifica como estamento burocrático e o papel do patrimonialismo na formação do Estado Nacional.

Inicia a sua interpretação do processo de formação política com a origem do Estado Português e é na formação do reino ibérico que está a origem da concepção que o Estado e o patrimônio do rei se confundem. Afirma que

do patrimônio do rei - o mais vasto do reino, mais vasto que o do clero e, ainda no século XIV, três vezes maior que da nobreza - fluíam rendas para sustentar os guerreiros, os delegados monárquicos espalhados no país e o embrião dos servidores ministeriais, aglutinados na corte. Permitia, sobretudo, a dispensa de largas doações rurais, em recompensa aos serviços prestados pelos seus caudilhos, recrutados, alguns, entre aventureiros de toda a Europa. ${ }^{106}$

Em relação ao poder local, apresenta-o como uma limitação aos poderes da nobreza e uma forma de garantir o poder do rei. O município é utilizado como "arma comum à estratégia política 
da realeza"107 e recebe proteção e autonomia por parte do rei através das cartas de foral. "Temerosa do domínio autônomo das camadas que a apoiavam - o clero e a nobreza - a realeza deslocou sua base de sustentação, criando as comunas e estimulando as existentes" ${ }^{108}$.

Esse incremento do poder real em detrimento aos poderes do clero e nobreza permitiram, segundo o autor, a centralização política de Portugal e a organização de expedições marítimas, responsáveis pela constituição do Império Português. O financiamento das atividades mercantis foi garantida graças à alianças com a burguesia, principalmente com a Dinastia de Avis.

Em relação à colonização, conclui que

a expedição de Martim Afonso de Sousa e o regime das capitanias hereditárias (1534-1549) se alimentaram de outro propósito, provavelmente o de fixar populações ociosas e assegurar, com a povoação, a defesa do território. (...) A colonização foi obra do Estado, como as capitanias representaram delegação publica de poderes, sem exclusão da realeza. ${ }^{109}$

Nesse ponto, verificamos que, para ele, o Estado na figura do rei, estava presente na tarefa colonizadora, diferentemente de Max Fleiuss que exaltou Martim Afonso como o responsável pela instalação das instituições políticas na nova colônia.

A leitura do Estado patrimonialista, de concepção weberiana, fica evidente quando Faoro relata que "as vilas se criavam antes da povoação, a organização administrativa precedia ao afluxo das populações. Prática que é modelo da ação do estamento, repetida no Império e na República: a criação da realidade pela lei, pelo regulamento. A América seria um reino a moldar, na forma dos padrões ultramarinos, não um mundo a criar"110.

A presença do rei se faz presente nas colônias através de representantes. A política prevalece sobre a economia, no que Faoro nomeou de capitalismo politicamente orientado, visto que "o 107 Raimundo Faoro. op cit., p. 21.

108 Raimundo Faoro. op. cit., p. 22.

109 Raimundo Faoro. op. cit., p. 129.

110 Raimundo Faoro. op. cit., p. 143. 
comando da economia e da administração deveria, para conservar o já tradicional edifício do governo português, concentrar-se nas zelosas e ciumentas mãos, mãos ávidas de lucros e pensões, do estamento burocrático"111. Apresenta uma visão diferente da de Caio Prado, afirmando que "o sentido da colonização está claro: o povoamento como obra auxiliar da conquista" ${ }^{12}$, isto é, o sentido da colonização para Faoro tem relação direta com o Estado patrimonialista conceituado por Max Weber ${ }^{113}$.

Em relação ao poder local, o autor relativiza-o, retomando a construção do município nos primeiros séculos de Portugal como forma de garantir poderes mais amplos ao rei frente à nobreza. Conclui que "na verdade, salvo um fugaz momento do estímulo régio de um século, estímulo que não busca a autonomia mas subordinação, por meio do compromisso, o município se submete ao papel de braço administrativo da centralização monárquica" "114. A centralização teve tanta importância para ele que até eventos considerados pela historiografia como exemplos de autonomismo e rebeldia são interpretados na lógica patrimonialista de Weber. "O primeiro ímpeto do bandeirismo paulista se deveu ao estímulo do sétimo governador-geral do Brasil (1591-1602), dom Francisco de Sousa, que buscava a descoberta de pedras e metais preciosos" ${ }^{\prime 15}$.

Por fim, conclui que a "característica principal, a de maior relevância econômica e cultural, será o do predomínio, junto ao foco superior de poder, do quadro administrativo, o estamento que, de aristocrático, se burocratiza progressivamente, em um processo de acomodação e sem mudanças estruturais" ${ }^{116}$. Aponta o patrimonialismo e a centralização administrativa como justificativas para a hipertrofia do Estado e da crise que culminou com a tomada de poder por Vargas em 1930. Porém, a “Revolução de 1930” não apresenta mudanças em sua visão. “O governo - a União encarnada no

111 Raimundo Faoro. op. cit., p. 164.

112 Raimundo Faoro. op. cit., p. 134.

113 Os conceitos de patrimonialismo, estamento e burocracia estão discutidos em Max Weber. Economía y sociedad. México: FCE, 1992.

114 Raimundo Faoro. op. cit., p. 212.

115 Raimundo Faoro. op. cit., p. 181.

116 Raimundo Faoro, op. cit., p. 823. 
presidente - era senhor de todos os instrumentos de comando político" $" 117$.

Em 1956 foram publicados os primeiro volumes da Coleção História Administrativa do Brasil, coordenada por Vicente Tapajós e editada pelo Setor de Documentação do Departamento Administrativo do Serviço Público (DASP), tinha como objetivo a reflexão sobre a história administrativa e proporcionar o embasamento para as reformas iniciadas no governo Vargas. No prefácio da coleção, Vicente Tapajós proclama a necessidade de se escrever uma "história definitiva" sobre a administração brasileira visto que Varnhagen, em sua História Geral do Brasil, "não fez a História do Brasil propriamente dita, apenas apresentou os fatos, elucidou problemas, abriu luz em muitos caminhos obscuros, criou, enfim, os alicerces sobre os quais repousa - ou repousará - a verdadeira e completa História do Brasil." 118

Os textos da coleção foram escritaos por professores do Colégio Pedro II, entre os quais Hélio de Alcântara Avellar, Alfredo D'Escragnolle Taunay e João Alfredo Libânio Guedes, além do próprio Vicente Tapajós. O primeiro volume, dividido em 2 tomos, aborda as "Preliminares Europeias" e a "Administração Manuelina", o segundo "A política administrativa de D. João III", o terceiro a "União Ibérica", o quarto "Da Restauração a D. João V" e o quinto versa sobre a "Administração Pombalina".

Apesar da coleção ser escrita por vários colaboradores, podemos interpretá-la em seu conjunto, a fim de verificar quais as intenções e objetivos da obra, bem como as referências bibliográficas que utiliza.

De maneira geral, a obra pouco difere da História Administrativa de Max Fleiuss. Na Revista do Serviço Público de 1955 foi publicado um editorial sobre a necessidade de se escrever uma História Administrativa do Brasil. O editorial é esclarecedor:

uma série de reformas, no terreno da Administração Pública, verificou-se de

117 Raimundo Faoro. op. cit., p. 791.

118 Vicente Tapajós. Prefácio. In: TAPAJÓS, Vicente (org.). História Administrativa do Brasil. Rio de Janeiro: Imprensa Nacional, 1956, vol. 1, p. 16. 
$1936^{119}$ para cá, no Brasil. (...) Impunha-se, portanto, a feitura de uma "História Administrativa do Brasil". É verdade que, da República para cá tivemos vários ensaios e pequenos estudos neste particular. Mesmo sem citar outros, podemos apontar Max Fleiuss, Basílio de Magalhães e Almir de Andrade, que nos deram roteiros cronológicos da vida administrativa da nossa nacionalidade. Mas, em verdade se diga, todos estes pequenos estudos se isolam em fragmentos e fatos parciais, sem a necessária amplitude que permita conhecer as particularidades dos fenomenos que nos atingiram em quase 500 anos de existência. (...) A "História Administrativa do Brasil" será fundamental em nossa vida cultural. Nela serão fixadas as bases de outros estudos, pois as suas raizes mestras promanam da longínqua e fecunda administração de D. João III. ${ }^{120}$

O DASP assume sempre uma postura de arauto da reforma e modernização do Estado. Em 1960, afirma em editorial que "na luta da racionalização administrativa no Brasil, tem sido este Departamento o pequeno David, lutando contra o Golias da corrupção e do nepotismo, existentes no serviço público civil da União"121.

Em nosso entender, a Coleção História Administrativa do Brasil, publicada em 1956, assumiu a postura de defesa das reformas impetradas pelo DASP. Escrever a história da administração anterior à 1930, como está no projeto inicial da coleção, é uma forma de marcar a diferença entre o que fora feito antes e legitimar as reformas. A partir dessa lógica, compreendemos melhor a indicação de professores do Colégio Pedro II para pesquisa e composição da coleção; tais escritores iriam apresentar uma visão conservadora do período anterior a 1930 e com isso reforçar a visão de que, a partir de 1930, iniciam-se reformas e a modernização do Estado brasileiro.

A partir dessas considerações iniciais, podemos analisar os volumes da coleção individualmente, a fim de verificar como era a concepção de administração colonial para os autores,

119 Nesse ano foi criado o Conselho Federal do Serviço Público Civil (CFSPC) pela lei no. 284 de 1936. Em 1938 o conselho teve sua denominação alterada para Departamento Administrativo do Serviço Público (DASP). Mesmo anterior à oficialização do DASP, o ano de 1936 é considerado como o início das reformas administrativas realizadas por Vargas.

120 EDITORIAL. Revista do Serviço Público. Rio de Janeiro, vol. 66, n. 1, jan. 1955, p. 3-4.

121 EDITORIAL. Revista do Serviço Público. Rio de Janeiro, vol. 88, n. 1, jul. 1960, p. 3. 
sem perder de vista o contexto em que a obra foi publicada.

Hélio de Alcântara Avellar, no primeiro volume da coleção, aborda o que denomina de preliminares europeias, ou seja, as estruturas administrativas portuguesas que foram a base do que se implantou na colônia americana. A ideia de continuidade das instituições é representada na ênfase que dá ao municipalismo, instituição essa que fora a primeira instalação administrativa colonial. Assim, na mesma perspectiva que Max Fleiuss e Caio Prado Jr., afirma que

Martim Afonso não fundou apenas a urbis. Desde o primeiro instante, lançou os fundamentos da civitas: nomeou oficiais para administração da justiça e convocou os homens bons para a eleição dos vereadores. Transpunha-se assim para o Brasil a instituição municipal portuguesa. Aplicavam-se os dispositivos a respeito contidos nas Ordenações. Tinha início o governo autônomo das vilas e se esboçava o sistema representativo. ${ }^{122}$

\section{Contesta a visão de Caio Prado ao reforçar que}

não obstante a importância que reconhecemos do município no Brasil português, discordamos da extensão que lhe deu Caio Prado Jr a ponto de afirmar: 'O Brasil colonial forma uma unidade política somente no nome. $\mathrm{Na}$ realidade é um aglomerado de órgãos independentes, ligados entre si apenas pelo domínio comum, porém muito mais teórico do que real, da mesma metrópole'. Isso equivaleria a restringir o estudo da história administrativa no período do funcionamento das câmaras locais, praticamente. ${ }^{123}$

No segundo tomo do primeiro volume, Alfredo Taunay trata da administração manuelina. Em linhas gerais, escreve que "nas três décadas seguintes ao seu descobrimento, o Brasil ficou relegado a relativo abandono por parte de Portugal, empolgado com as possibilidades de

122 Hélio de Alcântara Avellar. Preliminares Européias. In: TAPAJÓS, Vicente (org.). História Administrativa do Brasil. Rio de Janeiro: Imprensa Nacional, 1956, vol. 1, p. 28.

123 Hélio de Alcântara Avellar. op. cit., p. 29. 
enriquecimento que o Extremo Oriente proporcionava” ${ }^{124}$.

Porém o sonho português de manutenção de um vasto e rico Império não durou muito. Segundo Taunay, "para esse malogro, que deve ser considerado inevitável, dois fatores concorreram preponderantemente: a escassa população de Portugal e a má organização imprimida à conquista" ${ }^{25}$. Aponta a questão da administração colonial como fundamental para a manutenção e prosperidade de uma colônia.

O segundo volume, de autoria de Vicente Tapajós, trata da política administrativa de D. João III, momento em que se inicia a colonização do que hoje é o Brasil, por motivação de defesa do território frente a ataques de nações estrangeiras: "vê-se que a missão de Martim Afonso era, antes de tudo, colonizadora. Não lhe cabia apenas verificar a grandeza da terra e tomar posse dela, mas 'aproveitar e granjear' no melhor modo possível"126. A postura sobre a fundação do primeiro município em terras americanas é claramente marcada pela defesa de território, o que difere das interpretações de Max Fleiuss, Caio Prado e Raimundo Faoro.

Para Tapajós, a concessão de terras e forais foram fundamentais para a estruturação da colônia. Tanto que afirma: "para concluir, poderíamos usar a expressão lapidar de Max Fleiuss: 'a terra dividida em senhorios, dentro do senhorio do Estado - eis o esboço geral do sistema administrativo na primeira fase de nossa História',"127.

Mesmo abordando os poderes municipais, o faz de maneira descritiva e sem muitos detalhes. Foca sua análise nas figuras dos governadores-gerais, enfatizando não suas características pessoais, tal como Fleiuss fez para D. Pedro II, mas ressaltando suas habilidades administrativas. Em relação à Tomé de Sousa, afirma que "não há dúvida que foi habilíssima solução do administrador que lutava com a falta de homens e de meios. Propôs ainda, sempre na luta pela diminuição das

\footnotetext{
124 Alfredo D'Escragnolle Taunay. A administração manuelina. In: TAPAJÓS, Vicente (org.). História Administrativa do Brasil. Rio de Janeiro: Imprensa Nacional, 1956, vol. 1, p. 269.

125 Alfredo D'Escragnolle Taunay. op. cit., p. 273.

126 Vicente Tapajós. A política administrativa de D. João III. In: TAPAJÓS, Vicente (org. ). História Administrativa do Brasil. Rio de Janeiro: Imprensa Nacional, 1956, vol. 2, p. 24.

127 Vicente Tapajós. op. cit., p. 49.
} 
despesas, de pagamento difícil, que cargos fossem suprimidos ou dados em acumulação a um só personagem" 128 . Nesse trecho fica evidente a relação de Tomé de Sousa, apresentado como “administrador" e não como governador-geral, com a política de reforma do Estado idealizada pelo DASP. Mesmo propondo mostrar o passado anterior à Vargas como arcaico, figuras de destaque podem também aparecer como símbolos de mudança, indicando uma relação direta entre Getúlio e os "ilustres" da História Brasileira.

No terceiro volume, João Libânio Guedes aborda o período da União Ibérica. Inicia fazendo uma ressalva em relação ao período, defendendo que "o período da União Ibérica tem sido, na verdade, menosprezado sobretudo pelos que se inspiram em obras portuguesas eivadas de exagerado nacionalismo. Convém evitar esse desvirtuamento, que só prejudica a análise objetiva dos sucessos históricos"129. Afirma, portanto, que durante a união das coroas ibéricas, a autonomia de Portugal foi respeitada com o intuito de evitar revoltas e conflitos autonomistas.

Em relação à colônia portuguesa, João Alfredo resume que “a União Ibérica, para os colonos, foi, na verdade, um desafogo, pois ampliou as possibilidades de comércio. O monopólio português fora, em parte, rompido. Agora, o comércio se estendia à vasta rede mercante da Espanha"130. O estímulo à descoberta de minas de metais preciosos foi também marcante, a ponto de assinalar que "bem significativa foi a administração de D. Francisco de Sousa, que trazia por mercê o título de Marquês das Minas, se as descobrisse"131.

A busca por metais preciosos e a inexistência formal da linha do Tratado de Tordesilhas levou à expansão territorial da colônia portuguesa. Levou também à uma política de descentralização, com o intuito de "favorecer o seu desenvolvimento econômico e garantir maior flexibilidade de ação dos administradores" ${ }^{132}$, que teve como consequência a divisão da colônia em

128 Vicente Tapajós. op. cit., p. 107.

129 João Alfredo Libânio Guedes. União Ibérica. In: TAPAJÓS, Vicente (org.). História Administrativa do Brasil. Rio de Janeiro: Imprensa Nacional, 1956, vol. 3, p. 14.

130 João Alfredo Libânio Guedes. op. cit., p. 47.

131 João Alfredo Libânio Guedes. op. cit., p. 59.

132 João Alfredo Libânio Guedes. op. cit., p. 69. 
Estado do Brasil e do Maranhão, o que permitiu a ocupação lusitana da região amazônica.

Ele apresenta um balanço positivo em relação ao período da União Ibérica. Apesar da ocupação de extensas áreas por holandeses e franceses, a política de descentralização permitiu, em conjunto com a expansão para o oeste, o dilatamento da colônia portuguesa. Aponta o fim da União Ibérica e a Restauração de 1640 como motivada por descontentamentos por parte dos portugueses em relação a aumentos de impostos e redução da autonomia devido às guerras da Espanha contra Holanda, Inglaterra e França.

João Alfredo Libânio Guedes descreve um panorama do período focado na administração colonial. Ignora, porém, as instituições políticas e foca sua análise na descrição dos atos administrativos de reis e governadores. A própria estrutura de sua obra é significativa, seus capítulos sempre têm a mesma estrutura: a administração durante o reinado de ...

Para o quarto volume, João Alfredo aborda o período da Restauração a D. João V, o que inclui a consolidação do absolutismo e a reconquista das terras ocupadas pelos holandeses no Nordeste açucareiro. Aponta, em relação à administração colonial, que "após a restauração, com a secessão do reino de Portugal da União Ibérica, toda a máquina administrativa da monarquia portuguesa foi colocada a serviço imediato da política separatista e da sua consolidação" "133, ressaltando a importância da administração colonial para a retomada da autonomia política de Portugal.

Apesar da nova dinastia reinante em Portugal ser nacional, D. João manteve a política colonial iniciada por Filipe II. "A descentralização favoreceu a organização das duas forças de pressão [contra o Nordeste holandês]: a do norte e a do sul. E ambas agiram, a seu tempo, com a devida e necessária precisão" 134 .

A descentralização administrativa, a criação do Conselho Ultramarino em 1642 baseado no

133 João Alfredo Libânio Guedes. Da Restauração a D. João V. In: TAPAJÓS, Vicente (org.). História Administrativa do Brasil. Rio de Janeiro: Imprensa Nacional, 195-, vol. 4, p. 15.

134 João Alfredo Libânio Guedes. op. cit., p. 21. 
modelo espanhol indicam, segundo João Alfredo, uma centralização crescente que culmina com o Absolutismo no século XVIII. O crescimento do poder real contrasta com a dependência econômica e política de Portugal em relação à Inglaterra. Foi nesse período que a nação lusitana, para protegerse da ameaça espanhola teve de aceitar as condições inglesas, o que para João Alfredo foi extremamente negativo, pois "livrou-se Portugal da Espanha, mas caiu sob o guante de pior opressão: o imperialismo britânico que, como todos os imperialismos, esgota as energias vitais do povo economicamente escravizado" 135 .

Concluindo a obra sobre o período posterior à Restauração, João Alfredo tece algumas críticas à administração lusitana. Afirma que "não se salientou o reinado de D. João V por nenhuma medida administrativa de relevo"136 e que "tudo isso evidencia, mais uma vez, a ausência de uma planificação administrativa, que era, aliás, o defeito maior da administração colonial"137. Conclui apresentando críticas ao absolutismo, afirmando que marca "o reinado de D. João V o apogeu do absolutismo, mas do absolutismo na sua feição mais bronca e medíocre, eivado de exagerada beatice e sem nenhum vislumbre de espírito progressista" ${ }^{138}$.

No balanço sobre a colônia, escreve que "a administração primava pela rotina. Os únicos órgãos da administração que funcionavam com evidente vitalidade eram os do fisco da Fazenda Real. A única preocupação administrativa era cobrar impostos, exigir tributos, confiscar, enfim, sugar o máximo que podia das forças econômicas da colônia" ${ }^{139}$, levando à conclusão de que “virtualmente o Brasil não teve administração, embora uma ou outra vez houvesse alguma iniciativa administrativa parcial, digna de louvor" ${ }^{140}$.

Essas conclusões indicam um pensamento mais próximo à realidade dos autores do que em relação ao período estudado. Quando João Alfredo afirma não ter havido administração no Brasil,

135 João Alfredo Libânio Guedes. op. cit., p. 86.

136 João Alfredo Libânio Guedes. op. cit., p. 133.

137 João Alfredo Libânio Guedes. op. cit., p. 135.

138 João Alfredo Libânio Guedes. op. cit., p. 139.

139 João Alfredo Libânio Guedes. op. cit., p. 141.

140 João Alfredo Libânio Guedes. op. cit., p. 142. 
mesmo que virtualmente, está se referindo àquela implantada pelo DASP, cujas características são a racionalização do trabalho, a eficiência e a modernização do Estado. Mesmo com o intuito de escrever uma História Administrativa do Brasil para legitimar as reformas iniciadas pelo Estado Novo, os termos e a visão de Estado concebidas pelo DASP se tornam presentes no discurso dos historiadores, em algumas conclusões pontuais ou na identificação de figuras administrativas que entraram na tradição histórica como grandes estadistas.

O último volume da coleção trata da administração pombalina. Nessa obra, Hélio de Alcântara Avellar apresenta a figura de Pombal como o "homem-época", identificando-o como herói e baseando quase todo o estudo da administração do período nas ações dele no governo português.

Em relação às medidas de Sebastião José de Carvalho e Melo, Hélio Avelar conclui que, com as reformas administrativas, "o gabinete Pombal, sem dúvida, abalara a nação. 'Terremoto nas instituições', classificaram seu ministro epônimo. O mais importante de tudo, talvez, tenha sido despertar a comunidade lusíada para o novo espírito do setecentismo, forçando mentalidades retrógradas a aceitarem o reformismo da época" ${ }^{141}$. Nessa passagem, fica evidente a visão do autor da figura de Pombal como grande homem, cujas reformas foram essenciais para Portugal, contrariando os opositores ou "mentalidades retrógradas".

O discurso de reforma progressista em relação a Pombal é o mesmo utilizado por Getúlio Vargas e posteriormente pelo DASP para justificar suas reformas administrativas ${ }^{142}$.

As reformas daspianas eram concebidas como modernizadoras frente a um Estado arcaico e oligárquico. Hélio Avellar conclui de forma a quase deixar claro a analogia entre o DASP e Pombal, representado como herói ou "homem-causa". Durante o gabinete pombalino,

141 Hélio de Alcântara Avellar. A administração pombalina. In: TAPAJÓS, Vicente (org.). História Administrativa do Brasil. Rio de Janeiro: Imprensa Nacional, 195-, vol. 5, p. 61.

$142 \mathrm{Na}$ Revista do Serviço Público, o editorial afirma que "a reforma administrativa que está sendo processada no país, de 1930 para cá, é, por certo, o traço mais característico da obra governamental de Getúlio Vargas”. EDITORIAL.

Revista do Serviço Público. Rio de Janeiro, vol. 2, n. 1, abr. 1944, p. 145. 
a crescente racionalização das funções e fins do organismo estatal implicara, no triunfo das leis gerais e codificações sobre o direito costumeiro e foraleiro, na plena estruturação de um governo central, surgindo, afinal, com a concentração de poder pelo monarca, apoiado numa estrutura estamental que substituía o ministerialismo de feição gótica, o estado barroco, assim classificado por Spengler, em substituição aos estado remanescente do feudalismo germânico. Nesse estado barroco, imperante na Europa até a Revolução de 1789, e em Portugal, ainda mais longamente, chegando à Revolução de 1820, aliam-se a burguesia comercial e o estamento burocrático. ${ }^{143}$

Notamos, portanto, que grande parte da escrita da História Administrativa foi concebida em relação direta com o momento político que a produziu. Escrever sobre política de governantes no passado é também uma forma de refletir ações no presente. Max Fleiuss utilizou a história administrativa para resgatar a figura de D. Pedro II, enquanto que Caio Prado Júnior a utilizou para apresentar o passado como algo arcaico e justificar uma alteração política e econômica. A coleção do DASP seguiu por linha semelhante: a crítica do passado serviu para legitimar as reformas em andamento no presente. Em Raimundo Faoro, a relação se dá com o período em que escreveu, principalmente na $2^{\mathrm{a}}$ edição em 1975, marcado pelo autoritarismo dos governos militares. Para ele, a compreensão da formação do estamento burocrático será única possibilidade de conseguir-se uma real mudança do quadro político vigente.

Essas quatro obras, incluindo a coleção em cinco volumes, são a referência básica para a compreensão da história administrativa do Brasil, principalmente para o período colonial. A retomada sistemática das obras, muitas vezes citadas em trechos e raramente lidas na íntegra, possibilitam uma reflexão crítica em relação à produção historiográfica do assunto. Com a bibliografia básica discutida, podemos abordar agora estudos mais recentes, marcados por trabalhos acadêmicos, com abordagens mais pontuais e que elucidam melhor a administração colonial 
portuguesa na América.

Em 1969, Charles Boxer publica The portuguese seaborne empire (1415-1825), obra pioneira ao abordar o Império Português como uma unidade e apresentar suas relações dentro de um contexto global. Enfatiza que as relações comerciais e religiosas foram fundamentais para a constituição de um Império que englobava, em certo período, uma extensa área desde o Brasil até as Molucas.

Esse Império, além de considerável extensão territorial, impressiona devido à sua longa duração. Mesmo muito fragilizado, Portugal possuía, ainda no século XX, áreas remanescentes da expansão colonial, tais como Angola, Moçambique, Guiné, Goa, Timor e Macau.

Ele considera que o que assegurou a estabilidade para o Império Português foi justamente a capacidade de adaptação das estruturas administrativas às realidades locais. Para tanto, afirma que “entre as instituições características do Império português, e que ajudaram a manter unidas suas diversas colônias, havia o Senado da Câmara e as irmandades de caridade laicas, das quais a mais importante foi a Santa Casa de Misericórdia"144. Inclui, dessa forma, à estruturação da administração colonial, o poder local, representado pelas câmaras municipais, e as instituições religiosas, essas intimamente relacionadas com a administração local.

A abordagem de Boxer sobre o poder local possibilita uma melhor reflexão sobre a estrutura administrativa do Império português. Ao incluir o poder local como peça fundamental para a organização do Império marítimo, conclui que foi essa plasticidade das instituições, capazes de uma incrível adaptação às realidades locais, o que garantiu a excepcional duração do Império.

Contraria estudos como a História Administrativa do Brasil, por exemplo, que determina que a estruturação político-administrativa foi fruto meramente de decisões centralizadas e que ignoraram poderes mais locais.

A obra de Boxer destaca-se justamente por incluir fatores que até então não eram 
considerados na compreensão da estrutura do Império português: poder local e missionação. Essa última foi apontada como principal fator para a manutenção do Império até o Estado Novo português, mesmo para colônias economicamente deficitárias. Conclui que,

quando a crença de que era um povo escolhido por Deus para a expansão da fé foi reforçado pela popularização da lenda de Ourique e pelas correntes sebastianistas e messiâncias posteriores, o resultado foi um nacionalismo de durabilidade e firmeza excepcionais. Esse nacionalismo exaltado ajuda a explicar por que os portugueses conseguiram manter uma parte tão grande de seu precário império marítimo por tanto tempo, e por que se mostram tão relutantes em renunciar a qualquer parcela dele hoje em dia [1967], tanto em relação às colônias economicamente viáveis (Angola, Moçambique) como às outras (Goa, Guiné). ${ }^{145}$

Stuart Schwarz publica em 1973 o livro Sovereignty and Society in Colonial Brazil, no qual procura a compreensão das especificidades contemporâneas através do estudo da estruturação da burocracia colonial. Tem como foco de pesquisa a atuação dos magistrados enviados de Portugal para a Bahia e as suas relações com as elites políticas e econômicas locais.

Uma análise apressada poderia levar a impressão que os magistrados formados na metrópole poderia representar um esforço de centralização e consequente enfraquecimento das elites locais. Porém, refuta essa ideia ao afirmar que

os sóbrios magistrados, com seus graus universitários, que desembarcavam no cais de Salvador em junho de 1609 entravam no mundo colonial, no universo baseado em padrões tradicionais portugueses embora esses tenham sofrido transformações para que se acomodassem e, mesmo, superassem as peculiaridades da sociedade e da economia em formação. ${ }^{146}$

145 Charles Boxer. op. cit., p. 389.

146 Stuart Schwarz. Burocracia e sociedade no Brasil colonial. São Paulo: Perspectiva, 1979, p. 137, [tradução de Sovereignty and Society in Colonial Brazil, de 1973]. 
Esse "mundo novo", uma sociedade em formação, oferecia uma grande oportunidade para os magistrados, a entrada na elite local da colônia. "Os juízes do Tribunal Superior da Bahia estavam a procura dos benefícios disponíveis na colônia brasileira" ${ }^{147}$ e para isso, o envolvimento mais próximo com a elite local era de extremo interesse. Tal envolvimento não seria tão estranho, visto que "o mais surpreendente aspecto do governo do Brasil foi a interpenetração das duas formas supostamente hostis de organização humana: a burocracia e as relações pessoais de parentesco" 148 .

Tal interpenetração foi nomeada por Schwarz como o "abrasileiramento da burocracia", isto é, a capacidade da elite colonial de incorporar os elementos vindos da metrópole para que esses mantenham a estrutura favorável à esse grupo. Conclui que

a sociedade colonial demonstrava uma incrível habilidade para abrasileirar os burocratas - ou até a burocracia - isto é, integrá-los dentro dos sistemas existentes de poder e apadrinhamento. Os atrativos oferecidos pelos grupos e indivíduos da colônia e os desejos dos magistrados davam início ao processo de interpenetração. ${ }^{149}$

A incorporação dos magistrados podia se dar de duas formas, através da entrada desses em irmandades laicas, como a Santa Casa de Misericórdia, ou através dos casamentos com filhas de membros da elite local.

A participação em irmandades conferia status e diferenciação social em uma sociedade fortemente influenciada por valores religiosos. Porém, foi através dos casamentos que a incorporação dos magistrados foi mais efetiva. "O casamento servia de laço principal entre famílias e era o método mais eficiente de incorporar magistrados na sociedade local de forma permanente. As atrações para conseguir um desembargador para a família eram muitas." ${ }^{150}$, pois o casamento "Ihes daria a oportunidade de adquirir riqueza e propriedades que estivessem de acordo com a 
posição social a que tanto aspiravam"151.

Dessa forma, Stuart Schwarz conclui que a compreensão das estruturas administrativas colonial não deve resumir-se a uma simples visão dos poderes locais. Esses devem ser relacionados com os poderes centrais e, principalmente, ter como foco de atenção não a descrição das estruturas políticas, mas a compreensão de suas relações.

Seguindo a proposta de aprofundar os estudos sobre as relações dos poderes locais, mais notadamente nas câmaras, é publicado em 1983 o artigo Aspectos estamentais da estrutura social no Brasil colônia, de Laima Mesgravis.

Nesse artigo, a autora propõe uma mudança de foco nas pesquisas realizadas no período, focadas nas relações escravistas. segundo Mesgravis, "a indiscutível predominância das relações escravistas de produção na sociedade colonial encobriu outros aspectos esquecidos ou mal interpretados das diferenças que separavam as camadas dominantes das subordinadas" ${ }^{152}$.

Propõe, dessa forma, o estudo da composição das câmaras municipais, tendo como ponto central a expressão homem bom, que representaria uma diferenciação entre os homens brancos que poderiam exercer o poder político local e os que não poderiam, expressando uma diferenciação entre os europeus na colônia.

Dessa forma, "para ser 'homem bom' era preciso 'viver a lei da nobreza', 'tratar-se nobremente' o que, pelos costumes e pelas Ordenações, significava possuir cavalos de montaria, pajens ou criados, com todo estilo de vida que isto implicava" ${ }^{153}$. Isto é, não se exigia uma nobreza real, mas pretendida. Essa consideração é extremamente válida para compreender o porquê da valorização do ócio e da ostentação em todos os níveis sociais da colônia.

Com esse artigo, Laima Mesgravis contribui para a melhor compreensão da lógica de funcionamento do poder local nas câmaras municipais. Não ignora a importância das relações

151 Idem. op. cit., p. 271.

152 Laima Mesgravis. Os aspectos estamentais da estrutura social no Brasil colônia. Estudos Econômicos. São Paulo: IPE-USP, vol. 13. 1983, p. 799.

153 Laima Mesgravis. op. cit., p. 801. 
escravistas, fundamentais para a estruturação da sociedade colonial, mas contribui para a reflexão da visão de mundo do colonizador, principalmente no que se refere à conceituação de nobreza pretendida.

Seguindo o esforço de melhor compreender as estruturas administrativas do Império português, não podemos ignorar a obra organizada por Graça Salgado em 1985, Fiscais e meirinhos.

Nela, apresenta-se uma descrição detalhada das diversas funções administrativas, desde o plano central até o local, enfatizando as alterações ocorridas ao longo das décadas. Para tanto, utiliza-se das atribuições descritas nas Ordenações do Reino.

Como o interesse primeiro da obra é organizar e sistematizar a administração do Império, não houve uma maior problematização sobre suas estruturas. Para a apresentação da obra, o histórico da evolução administrativa portuguesa focou-se mais em uma construção tradicional da história, enfatizando os feitos dos reis e altos cargos do Império, não diferenciando muito das obras de Raimundo Faoro e da coleção História Administrativa do Brasil.

Em 1993, Nuno Gonçalo Monteiro publica o artigo Os concelhos e as comunidades na coleção História de Portugal, organizada por António Manuel Hespanha. Nesse texto, Monteiro apresenta uma síntese da historiografia sobre o poder local em Portugal, afirmando que

no decurso da última década, o tema do poder municipal foi, inquestionavelmente, um daqueles em que de forma mais acentuada se fez sentir a mutação das perspectivas historiográficas anteriormente prevalecentes. A herança do municipalismo romântico, consubstanciada, antes de mais, na obra de Alexandre Herculano, legara à posterioridade essa imagem idealizada (e raras vezes questionada) dos projectados municípios e da sua antevisão medieval, ao mesmo tempo que construíra o seu contraponto negativo. ${ }^{154}$

154 Nuno Gonçalo Monteiro. Os concelhos e as comunidades. In: HESPANHA, António M. (org.). História de Portugal. Lisboa: Estampa, 1994, p. 303. 
Contraria, portanto, a visão estabelecida de que houve uma efetiva centralização da monarquia portuguesa mas também não defende a visão que denomina de "romântica" que defende uma autonomia dos municípios portugueses. Apresenta, dessa forma, a visão de que interpretações gerais sobre os municípios não permitem uma melhor compreensão sobre sua dinâmica e que somente a análise de seu funcionamento e relações entre os grupos sociais é que podem contribuir à questão.

Monteiro, para compreender as relações entre os grupos dos poderes locais utiliza-se dos conceitos de Max Weber para cargos honorários e patrimonialismo na burocracia administrativa. Afirma que,

subjacente à actuação da coroa parece estar um modelo que se aproxima singularmente do que Max Weber (1944) definiu como a administração dos honoratiores. Supunha-se que os membros das famílias localmente mais prestigiadas e antigas dispunham de uma autoridade natural, ou seja, sedimentada pelo tempo, que mais facilmente seria acatada pelos de baixo. Pensava-se também que os mais nobres e ricos seriam igualmente os que davam maiores garantias de isenção (desinteresse) e independência no desempenho dos seus ofícios, no sentido de poderem viver para eles sem deles viverem. ${ }^{155}$

Essa disputa por cargos municipais como forma de agregar vantagens foi mais presente nos concelhos mais importantes. Em relação à comparação entre câmaras importantes e mais locais, conclui que,

em primeiro lugar, era, no mínimo duvidoso que a participação nas pequenas câmaras acrescentasse prestígio social (status), sobretudo a quem já o tinha: uma grande parte dos juristas considerava, por exemplo, que só o 
desempenho de ofícios nos senados de "cidades e vilas notáveis" conferia nobreza, não ocorrendo o mesmo nas pequenas câmaras, "rústicas". 156

No que se refere a um esforço de centralização administrativa, Monteiro afirma que, a partir da segunda metade do século XVIII, há o início de uma preocupação em restringir os poderes das câmaras mais destacadas. Tal esforço, marcado por decisões do poder central, não representa, como é fácil compreender, uma real efetivação de tais interesses. O que o autor quer ilustrar é o início de um processo de centralização, que foi marcado por embates nem sempre favoráveis aos esforços centralizadores.

Em 1994 é publicada As vésperas do Leviathan, de Antonio Manuel Hespanha, que propõe uma revisão historiográfica sobre a centralização da monarquia portuguesa. Afirma que a imagem de uma centralização precoce foi fruto de uma historiografia mais preocupada com um história institucional, em que a centralização é apresentada como uma das características principais da monarquia portuguesa e fator importante para sua empresa marítima. Dessa forma, a centralização, segundo Hespanha, foi aceita sem que houvesse uma problematização maior sobre o assunto.

Com esse intuito, propõe uma revisão sobre o tema e, para isso, utiliza-se de conceitos políticos de Max Weber e como fonte documental baseia-se no Livro das Avalliações de todos os officios do Reyno de Portugal, de 1640.

Tendo como base documental uma descrição de todos os ofícios do reino, inicia uma descrição de todas as atividades político-administrativas. Inicia com os oficiais locais e parte, paulatinamente para os ofícios palatinos, mais centrais.

Após apresentar os ofícios, pondera-os para discutir a questão da centralização. Conclui que

traçado este panorama dos grandes ramos do aparelho políticoadministrativo, na periferia e no centro, importa fazer um balanço final, em que se avalie a importância relativa desses ramos, se visualize o peso que

156 Nuno Gonçalo Monteiro. op. cit., p. 326. 
este aparelho tem em relação à população do reino (notando as eventuais assimetrias regionais) e se determine o peso de cada uma das principais categorias de oficiais no conjunto. Por volta de 1640, existem em Portugal cerca de 11700 oficiais da administração periférica, a que haverá que somar cerca de 500 outros da administração palatina. ${ }^{157}$

Dessa forma, a administração portuguesa não é vista como centralizada, devido a maior quantidade de oficiais da administração periférica em relação aos do poder central. Além do mais, enfatiza a autonomia que a legislação delegava aos poderes locais.

O autor apresenta a administração portuguesa como uma "constelação de poderes" e com uma "burocracia decerebrada". A manutenção do Império estaria mais no equilíbrio dos poderes do que na capacidade de gestão do rei. Porém, nem mesmo nesse equilíbrio encontramos um projeto formalizado, pois

este equilíbrio nada tem a ver com um projecto pensado, com uma estratégia consciente, com as construções teórico-dogmáticas dos pensadores do poder e da sociedade. Antes resulta, preteritencionalmente, da acção dos homens e dos mecanismos objectivos da prática do poder. ${ }^{158}$

A interpretação da questão da centralização por António Hespanha teve como principal contribuição colocar a questão no foco das discussões historiográficas. A visão de "constelação de poderes" e o questionamento em relação à centralização administrativa não foi aceita de forma unânime. Há críticas em relação à interpretação, entre as quais podemos citar Laura de Mello e Souza em $O$ Sol e a sombra, em que ela aponta que foi dada uma evidente importância aos ofícios locais em detrimento aos centrais. E mesmo a escolha de iniciar a descrição dos poderes de Portugal pelos poderes locais, ou seja, partindo do específico para assim chegar ao geral, já denota um interesse em valorizar os poderes periféricos.

157 António Manuel Hespanha. As vésperas do Leviathan. Coimbra: Almedina, 1994, p. 259.

158 António Manuel Hespanha. op. cit., p. 526. 
Seguindo a interpretação iniciada por Hespanha, destaca-se o artigo de Maria Fernanda Bicalho, As câmaras municipais no Império Português: o exemplo do Rio de Janeiro, de 1998. Nesse, a autora detém-se em elementos comuns às câmaras no Império, tais como a defesa da costa e a administração da vida econômica.

Essas atribuições, compreensíveis em um Império de dimensões globais, representam para a autora um espaço de ampla autonomia. Afirma que "a Câmara do Rio de Janeiro, além de "lançar tributos sobre si', gozou, durante todo o século XVII, de uma autonomia impensável para quem se detém no estudo de suas funções na centúria seguinte" ${ }^{159}$.

Em relação à centralização, conclui que "não obstante, a partir de finais do século XVII e início do XVIII, o exacerbado poder político e econômico das Câmaras Municipais Ultramarinas foi sendo progressivamente cerceado pela Metrópole"160.

E, para a compreensão do papel das câmaras dentro do contexto de centralização do Império, destaca que os títulos e honras concedidos aos municípios "podem ser analisados como elemento instituidor de uma 'economia moral do dom', de acordo com a qual aqueles beneficiados passariam a estar ligados ao monarca através de uma rede baseada em relações assimétricas de troca de favores e serviços" ${ }^{\prime 161}$.

Defende, portanto, que a unidade do Império estava relacionada à uma economia de trocas simbólicas. Tal imagem não corresponde, por exemplo, às interpretações de Nuno Gonçalo Monteiro e de Laima Mesgravis, em que há uma maior elucidação de como se operavam os valores de distinção social na sociedade portuguesa.

Em 2005, Rodrigo Ricupero defende a tese de doutoramento intitulada Honras e mercês: poder e patrimônio nos primórdios do Brasil, em que apresenta uma interpretação sobre o processo de colonização ocorrido na América Portuguesa, adotando uma abordagem que difere da

159 Maria Fernanda Bicalho. As Câmaras Municipais no Império Português: o caso do Rio de Janeiro. Revista Brasileira de História, vol. 18, n. 36, 1998, p. 258.

160 Maria Fernanda Bicalho. op. cit., p. 259.

161 Maria Fernanda Bicalho. op. cit., p. 262. 
historiografia sobre administração colonial.

Ao considerar o início da colonização no Brasil, diverge da posição adotada, principalmente por autores mais tradicionais ${ }^{162}$, ao afirmar que a empresa colonial não denotou fragilidade da atuação do rei, mas sim uma estratégia de controle e gestão das novas conquistas. Afirma que,

no processo de colonização do Brasil, a Coroa utilizou-se da iniciativa particular e nela se apoiou, buscando, porém, sempre seu controle. Se, na perspectiva do Estado contemporâneo, essa situação pode ser vista como fragilidade, à época, no processo de formação do Estado, tal política constituiu hábil recurso: a Coroa utilizava recursos humanos, e financeiros particulares para viabilizar seus projetos, sem que lhe coubesse nenhum ônus, cedendo, em troca desse apoio, terras, cargos, rendas e títulos nobiliárquicos. ${ }^{163}$

Essa condição, que segundo Ricupero foi fundamental para a construção do aparato de exploração colonial, foi adotada por alguns séculos. Logo que a colonização portuguesa estabeleceu-se e começou a operar, a postura do Império Português foi outra, pois

esta situação - de maior liberalidade - foi-se alterando ao longo da segunda metade do XVI e início do XVII, quando uma série de decisões da Coroa, particularmente no que toca à implementação do 'exclusivo' comercial e às restrições crescentes à escravização dos índios, com o incentivo paralelo ao tráfico de escravos africanos, acabou por permitir a consolidação da exploração colonial. ${ }^{164}$

O autor apresenta de forma clara o processo de construção da colônia portuguesa em terras americanas, que, se não for vista em seu conjunto, levando em consideração suas conjunturas, pode

162 Autores como Max Fleiuss e grupo ligado ao DASP, como Vicente Tapajós, Hélio de Alcântara Avellar e Alfredo Taunay.

163 Rodrigo M. Ricupero. A formação da elite colonial. São Paulo: Alameda, 2009, p. 13.

164 Rodrigo M. Ricupero. op. cit., p. 24-25. 
levar a interpretações equivocadas.

Para o estabelecimento da empresa colonial usa recursos de colonos, que teriam como retribuição honras e mercês. Tais indicadores de distinção social não podem ser compreendidos segundo a lógica capitalista, pois os mesmos não garantem, necessariamente uma maior acumulação de capital que gerasse riqueza. Nem podem, como foi feito por António Manuel Hespanha e Fernanda Bicalho, indicar o que foi denominado "economia do dom".

Para tal questão, Ricupero utiliza-se do conceito de patrimonialismo cunhado por Max Weber e adotado na história administrativa do Brasil inicialmente por Raimundo Faoro e por Stuart Schwarz. Porém, não segue a interpretação de Faoro sobre a questão da centralização administrativa operada pelo rei, mas percorre os caminhos abertos por Schwarz, na compreensão da formação de uma elite local na Bahia seiscentista.

Dessa forma, o modelo patrimonialista da colonização pode ser verificado na forma em que se deu a participação ativa dos colonos na colonização, pois

as promessas régias de honras e mercês feitas pelos monarcas caíam em solo fértil, os vassalos das partes do Brasil, nascidos no Reino ou na colônia, ávidos pelas recompensas, procuravam de todas as formas fazerem jus a elas, assumindo os mais variados encargos do processo de colonização. ${ }^{165}$

Com essas considerações feitas, ele defende a ideia que a história dos funcionários coloniais deve ser mais aprofundada, visto que tal conjunto "continua extremamente mal conhecido, tanto em seus aspectos formais (provimentos, instruções, emulamentos etc) como em sua origem social ou em suas relações com a sociedade" ${ }^{166}$.

Discutindo com a obra de Stuart Schwarz, afirma que 
o casamento dos funcionários régios com as filhas dos grupos dominantes coloniais não era, contudo, a única forma de intervenção. Na verdade, para o período inicial da colonização, pode-se dizer que grande parte dos membros do governo da conquista procuraram se inserir nas atividades produtivas e, inclusive, comerciais, formando grandes patrimônios fundiários e possuindo considerável escravaria. ${ }^{167}$

E na conclusão do trabalho, Rodrigo Ricupero considera que

na trajetória desta pesquisa, pode-se dizer que nosso ponto de partida foi a busca da gênese da elite colonial e que nosso ponto de chegada foi a montagem do Antigo Sistema Colonial. A existência de uma elite colonial residente e engajada no processo de colonização, todavia, fez com que a exploração que se estruturou nas partes do Brasil acabasse tomando feições próprias, diferindo do que se implantou nas colônias inglesas, francesas e holandesas. ${ }^{168}$

\section{4 - Historiografia sobre Poder Local}

Em 1920, Afonso Taunay publica a obra São Paulo nos primeiros anos, em que propõe realizar um "ensaio de reconstituição social" ao abordar aspectos do cotidiano político e econômico da vila de São Paulo durante o século XVI. Tal empresa, considerada pelo autor como "o mais pitoresco terreno e até hoje absolutamente virgem" "169, somente foi possível pela transcrição e publicação das Atas da Câmara da vila e cidade de São Paulo, realizada na gestão de Washington Luís frente à Prefeitura dessa cidade.

Para a organização do poder local, representado pelas câmaras municipais, Taunay diz que “constituía o Código Filipino o livro básico por onde se regia a sociedade paulistana quinhentista" 170 . Em relação à composição da câmara "era em obediência às suas determinações que 
a edilidade da vila de Piratininga compreendia um juiz ordinário, dois vereadores e um procurador do concelho, assistidos de almotacel e alcaide" ${ }^{171}$.

O cargo na Câmara era revestido de prestígio e privilégios, ele considera que, mesmo no século XVI, “já era sobremodo honroso e vantajoso ter de suportar o 'peso da república' como se dizia em estilo de cronista"172.

Segue descrevendo os cargos concelhios, baseando-se no texto das Ordenações Filipinas. Para os juízes ordinários, Taunay afirma que "competia-lhe superintender a polícia da vila, a ele subordinando-se o alcaide e os 'seus homens"'173, além de garantir a justiça e a paz no âmbito local. Tais atribuições eram, "pois, altamente prestigiosas e prestigiadas as funções de juiz ordinário" 174 .

Para os vereadores,

pertencia ter cargos de todo o regimento da terra. (...) Fizessem sessão às quartas e sábados, multados em cem réis os remissos ausentes, procurassem ser os informadores dos juízes ordinários, cuidassem do patrimônio municipal, tomassem contas aos procuradores e tesoureiros do Concelho, controlassem empreitadas e avenças por jornais, tratassem de garantir $o$ suprimento de carne e pão, pusessem em praça as rendas do Concelho e lhes fiscalizasse a arrecadação, superintendessem as obras dos caminhos; entradas e saídas; cuidassem dos aforamentos e fizessem concessões, zelassem pelo arquivo e benfeitorias públicas, provessem quanto às posturas e taxas, "aos oficiais mecânicos, jornaleiros, mancebos, moças de soldada, louça e demais coisas que se comprassem e vendessem, segundo a disposição da terra e qualidade do tempo". ${ }^{175}$

O procurador do concelho era

o advogado natural da edilidade, acompanhava-lhes os feitos e por seu intermédio a ela vinham ter as queixas e reclamações populares; 'requererá

171 Afonso de Taunay. op. cit., p. 32.

172 Afonso de Taunay. op. cit., p. 33.

173 Afonso de Taunay. op. cit., p. 34.

174 Afonso de Taunay. op. cit., p. 34.

175 Afonso de Taunay. op. cit., p. 34. 
bem, lhe recomendava a Ordenação, todos os adúbios e consertos que cumprirem às casas, fontes, pontes, chafarizes, paços, calçadas, caminhos e todos os outros bens do Concelho, e assim procurará todos seus feitos em tal maneira que não percam nem danifiquem por sua falta. ${ }^{176}$

Aos almotacéis, "fiscais da época, tocava examinar as questões relativas aos problemas diários da existência sobre 'os carniceiros, padeiras, regateiras, almocreves, alfaiates, sapateiros e todos os outros oficiais', para que 'houvesse mantimentos em abastança, guardando-se as vereações e posturas do Concelho"177.

A eleição dos almotacéis ocorria mensalmente e "cabia aos juízes do ano transato almotaçarem no primeiro mês do novo período, no segundo os vereadores mais antigos, no terceiro um vereador e o procurador. Depois serviam os escolhidos pela Câmara dentre os homens bons" ${ }^{178}$.

O processo eleitoral dos oficiais da câmara, juiz ordinário, vereadores e procurador, seguia às disposições reguladas pelas Ordenações do Reino. O processo, seguido das descrições dos rituais praticados pode ser consultado na obra de Afonso de Taunay, São Paulo nos primeiros anos e nas próprias Ordenações ${ }^{179}$. Ressaltamos que, não obstante à repetição da descrição do processo eleitoral na historiografia sobre poder local, não encontramos estudos mais aprofundados sobre quem eram os eleitos e a quais grupos pertenciam.

Em relação à atuação dos oficiais da câmara, Taunay conclui que "já por várias vezes notamos a atitude independente das câmaras paulistanas quinhentistas. Ciosas de seus direitos e prerrogativas, frequentemente, no decorrer do século XVI, fizeram frente à prepotência de capitãesmores e ouvidores" 180 . Apresenta que a justificativa para tal postura "o perigo possível, ante a apreensão da escrava, do amotinamento geral dos índios, então muito exaltados" ${ }^{181}$.

Caio Prado Jr, em Formação do Brasil contemporâneo, de 1942, desenvolve uma

176 Afonso de Taunay. op. cit., p. 34.

177 Afonso de Taunay. op. cit., p. 35.

178 Afonso de Taunay. op. cit., p. 35.

179 Para o texto legal sobre o processo eleitoral, consultar Ordenações Filipinas, liv. I, tít. LXVII.

180 Afonso de Taunay. São Paulo nos primeiros anos e São Paulo no século XVI. São Paulo: Paz e Terra, 2003, p. 78.

181 Afonso de Taunay. op. cit., p. 79. 
interpretação sobre o poder local enfatizando seu caráter desorganizado e confuso. Para o autor, o órgão administrativo

mais importante é o Senado da Câmara que tem sua sede nas vilas ou cidades, e estende sua jurisdição sobre o termo respectivo. Há de se estranhar que falando da administração geral das capitanias, comece pelas Câmaras, que são órgãos típicos da administração local. Mas aqui, mais uma vez, devemos pôr de lado nossas concepções atuais. No sistema administrativo da colônia, já o assinalei, não existiam administrações distintas e paralelas, cada uma com esfera própria de atribuições: uma geral, outra local. A administração é uma só e ver-se-á, pelo desenvolvimento do assunto, que são tanto de ordem geral como local. Elas funcionam efetivamente como órgãos inferiores de administração geral das capitanias. ${ }^{182}$

Conclui Caio Prado que é "sempre difícil precisar o que é da competência privativa da Câmara. Em todos os seus negócios vemos a intervenção de outras autoridades, sobrepondo-se a ela ou correndo-lhe parelhas (...). O governador também se imiscui nos assuntos municipais"183.

A visão de autonomia das câmaras foi desenvolvida por Edmundo Zenha, que na obra $O$ município no Brasil, de 1948, apresenta o município como elemento tradicionalmente democrático na estrutura político-administrativa do período colonial.

Para Zenha, "a vila era a maneira mais fácil do português compreender a colonização, o que denunciou a tendência popular de que sempre esteve imbuído o povo que nos colonizou" ${ }^{184}$. Justifica essa postura apresentando que "não se criam municípios no Brasil para a realização de obras públicas. Os povos, quando os pedem, querem policiar a terra, implantar nela um organismo distribuidor de justiça, porque a del-rei era distante, demorada e cara"185. Tal isolamento em relação ao poder central pode ser considerado, segundo ele, como um elemento para justificar uma maior autonomia do poder do município.

182 Caio Prado Jr. Formação do Brasil contemporâneo. São Paulo: Brasiliense, 1945, p. 314.

183 Caio Prado Jr. op. cit., p. 317.

184 Edmundo Zenha. O município no Brasil. São Paulo: I.P.E., 1948, p. 23.

185 Edmundo Zenha. op. cit., p. 31. 
No tocante à atuação dos camaristas, o autor afirma que "um sem número destas funções não eram remuneradas o que não impedia, entanto, que se formasse o nódulo burocrático sempre entravante e sempre dispendioso"186. E conclui que "mais popular, pois, e democrática, não podia ser a instituição municipal no Brasil-Colônia""187.

Edmundo Zenha nos faz reflexões importantes sobre o papel dos oficiais da câmara. "O sistema vigente oferecia vantagens - permitia-lhes, aos colonos, trabalhar naquilo que fossem hábeis e, quando se achassem regularmente seguros de suas economias, deixavam o ofício e igualavam-se com os demais. Antônio Alves, por exemplo, desiste do ofício de seleiro para 'gozar das outras liberdades dos homens-nobres', declara. E o deixa porque já se considera com suficiente para fazê-lo" ${ }^{188}$. Se tal situação ocorre com homens que enriquecem, é plausível considerar que o sentimento de distinção conferido aos oficiais dos concelhos fossem por eles interpretados como equiparados às leis de nobreza.

Essa proeminência social dos camaristas fez com que "o Senado da Câmara passasse a ser um resumo das famílias dominantes e o seu mais autorizado porta-voz. E foi sustentado pela família colonial que o município tornou-se no Brasil tão prestigioso, às vezes arrogante, outras revolucionário" 189 .

O caráter democrático e, consequentemente, autônomo, apresentado por ele, reforça a ideia de que o municipalismo foi importante fator na construção da estrutura político-administrativa colonial. Cita que “a expulsão dos jesuítas em 1640 de São Paulo mostra a que ponto de desenvolvimento havia chegado o municipalismo naquele período. O povo tem ampla interferência no movimento e a instituição age com admirável precisão" ${ }^{190}$.

O relevante papel que as câmaras tiveram na organização do Império Português é ressaltada na obra O Império maritimo português, de 1969. Boxer destaca o papel social que oferecia os

186 Edmundo Zenha. op. cit., p. 67.

187 Edmundo Zenha. op. cit., p. 78.

188 Edmundo Zenha. op. cit., p. 94-95.

189 Edmundo Zenha. op. cit., p. 132.

190 Edmundo Zenha. op. cit., p. 162. 
cargos públicos aos oficiais através da máxima: “'Quem não está na Câmara está na Misericórdia', dizia o provérbio alentejano, e isso também valia para as duas instituições no ultramar" ${ }^{191}$.

Boxer relativiza o papel dos camaristas, ao contrário da postura adotada por Edmundo Zenha. Para o primeiro, “devemos reconhecer que, apesar dos concelhos coloniais em geral se constituírem de indivíduos conscienciosos, que levavam a sério seus deveres - como uma leitura cuidadosa dos arquivos pode comprovar - eles eram, inevitavelmente, instâncias de nepotismo, corrupção e desvio de fundos da municipalidade" 192 .

Raimundo Faoro, que em 1975, publica a segunda edição de Os Donos do Poder, apresenta uma concepção patrimonialista do processo de formação de Portugal.

Em relação aos municípios, afirma que foram esses "arma comum à estratégia política da realeza na Europa, recebendo especial estímulo, na mesma medida em que se ensoberbeciam os potentados rurais" 193 , visto que, "temerosa do domínio autônomo das camadas que a apoiavam - o clero e a nobreza - a realeza deslocou sua base de sustentação, criando comunas e estimulando as existentes, no incremento da realidade capaz de lhe proporcionar suporte político, fiscal e militar" ${ }^{\prime 194 .}$

\section{5 - Estado Atual da Questão sobre Fontes do Direito Português}

Para compreendermos a estrutura administrativa do Império Português, é necessário abordar a questão do Direito Português e seus usos nas colônias. Não obstante a importância do assunto, optamos por realizar uma apresentação do assunto e não uma análise sistemática.

Não encontramos na historiografia brasileira estudos sistemáticos sobre a história do Direito

191 Charles Boxer. op. cit., p. 299.

192 Charles Boxer. op. cit., p. 297.

193 Raimundo Faoro. Os Donos do Poder. São Paulo: Globo, 2003, p. 21.

194 Raimundo Faoro. op. cit., p. 22. 
para o período colonial. Como exemplo, podemos apontar o ensaio História do direito brasileiro, de César Trípoli, de 1936, e artigo de Ignacio Poveda, denominado Ordenações do reino de Portugal, de 1994.

O estudo de História do Direito no Brasil não se deu de forma contínua, apesar do estabelecimento de lições de História do Direito Civil, Romano e Português com a criação dos Cursos Jurídicos em 1827.

De acordo com Luiz Carlos de Azevedo, a história do direito

como disciplina integrante do curso jurídico já se encontra consolidada: na verdade, desde 1772, quando da reforma dos Estatutos da Universidade de Coimbra e a conseqüente instituição das lições de História do Direito Civil, Romano e Português, desde 1827, quando da criação dos cursos jurídicos no Brasil, ao participar, naturalmente, do programa das disciplinas que compunham o currículo; de modo mais específico, desde 1891 quando da Reforma do Ensino Jurídico e a adoção da cadeira de História do Direito Nacional; a partir de 1895, com o nome de História do Direito especialmente do Direito Nacional; e, finalmente, desde $1990^{195}$, quando passou a ser novamente lecionado no curso de graduação. ${ }^{196}$

Portanto, a retomada apenas em 1990 das disciplinas História do Direito e do Pensamento Jurídico I e II, atuais História do Direito I e II, contribuem para explicar a pequena quantidade de trabalhos sobre o tema. No banco de dados Dedalus ${ }^{197}$, consultando dissertações e teses de doutoramento sobre história do direito luso-brasileiro, excetuando produções ligadas à temática do Direito Romano, encontramos poucos títulos.

Diante da escassez de trabalhos sistemáticos sobre História do Direito no Brasil, optamos por

195 Sessão de 30 de maio de 1989, da Comissão de Graduação, pelo presidente prof. Antonio Junqueira de Azevedo e ofício datado de 4 de julho desse mesmo ano, endereçado pelo então Diretor da Faculdade de Direito, prof. Dalmo de Abreu Dallari, à Secretaria da Universidade de São Paulo. (ofício ATC/155/FD/04/07/1989)

196 Luiz Carlos de Azevedo. História do direito, ciência e disciplina. Revista da Faculdade de Direito da Universidade de São Paulo. São Paulo, v. 92, jan/dez, 1997, p. 47.

197 Banco de dados sobre as bibliotecas da Universidade de São Paulo. 
apresentar um estado atual da questão e não uma discussão historiográfica.

Em 1976, Luiz Carlos de Azevedo defende a dissertação intitulada Origem e introdução da apelação no direito luso-brasileiro, orientada pelo Prof. Dr. Moacyr Lobo da Costa. Graziela F. Buscarin Lima, sob orientação do Prof. Dr. Ignacio M. Poveda Velasco, defende, em 2002, a dissertação intitulada Evolução histórica da propriedade territorial no Brasil. Em 2004, Maria Cristina da Silva Carmignani, defende a tese de doutoramento, sob orientação do Prof. Dr. Luiz Carlos de Azevedo, intitulada $O$ direito judiciário na história: a experiência romana e lusobrasileira. Em 2005, Ângelo Rigon Filho defende a dissertação Evolução histórica da filiação no direito brasileiro, orientada pelo Prof. Dr. Ignacio M. Poveda Velasco. No mesmo ano, José Rubens de Moraes, sob orientação do Prof. Dr. Roque Komatsu, defende a dissertação de mestrado intitulada Evolução histórica da execução civil no direito lusitano.

Observando um padrão na produção acadêmica sobre o tema, encontramos, no período anterior ao restabelecimento das disciplinas de História do Direito, apenas um título, de 1976. Após 1990, encontramos quatro títulos, sendo três sob orientação do Prof. Ignacio M. Poveda Velasco, titular da área de História do Direito do Departamento de Direito Civil da Faculdade de Direito da Universidade de São Paulo.

Apesar da recente produção sobre História do Direito na Universidade de São Paulo, não encontramos pesquisas sistemáticas focadas nas características das fontes de direito lusas. Verificamos pesquisas focadas em temas, tais como direito de filiação, execução processual civil, direito de propriedade e relação entre direito e atuação social.

Tal situação denota uma área recente, em que não há uma identidade clara em sua atuação. As pesquisas da área encaram a História do Direito não como disciplina autônoma, mas como ferramenta complementar para o estudo das demais áreas jurídicas.

Para a reflexão da implementação do Direito Português nos domínios do Império, devemos iniciar refletindo sobre a formação do Direito em Portugal, para assim podermos analisar como essa 
instituição foi adotada nas colônias.

De acordo com César Trípoli ${ }^{198}$, o Direito no Império Português pode ser divido em três esferas: o Direito comum português, isto é, as leis gerais do Império, representadas pelas Ordenações do Reino e pelas fontes de Direito subsidiário; o Direito colonial português, representado pelos decretos régios, alvarás expedidos pela administração colonial e, posteriormente a 1642, pelo Conselho Ultramarino, e, o Direito local, aspecto esse mais relevante para o presente estudo, que se refere aos atos dos governadores e câmaras municipais, esfera essa em que os costumes e tradições apresentam-se mais influentes.

\section{Direito Português}

As leis gerais do Império foram organizadas em três Ordenações: Afonsinas, Manuelinas e Filipinas, além de uma compilação de leis posteriores, denominada Leis Extravagantes. O contexto de criação dos códigos, suas características e qual o papel dos usos e costumes na sua formação são os elementos que nortearam a presente apresentação.

As Ordenações Afonsinas foram finalizadas em 1446, durante o reinado de D. João I, primeiro monarca da nova Dinastia de Avis. Segundo José Domingues, esse reinado

marca, antes de mais, o termo da primeira dinastia do reino de Portugal, dinastia afonsina, e o princípio de uma outra, a dinastia de Avis. Esta mudança de linhagem real resultou da grave crise de sucessão a que a morte de el-rei D. Fernando tinha votado o país. Com o falecimento deste soberano, a 22 de outubro de 1383, sem qualquer descendência masculina, a legítima sucessora da coroa portuguesa passaria a ser a sua filha, infanta D. Beatriz, casada com o monarca de Castela, D. João. Aliada a uma sucessão legítima a infanta contava ainda com o juramento de fidelidade prestado à data do seu casamento pela grande maioria da nobreza portuguesa. Mas o senão deste

198 Cesar Trípoli. História do direito brasileiro (ensaio). São Paulo: Revista dos Tribunais, 1936, vol. 1, p. 54. 
sucedimento era, sem dúvida, o da perda da independência do reino para Castela. Esta eminência da perda da autonomia levantou um partido contestário que acabou por apoiar o ascenso de D. João, coevo mestre da Ordem de Avis e irmão do falecido monarca, rei de Portugal. ${ }^{199}$

Em tal contexto, a criação de uma legislação portuguesa reforçaria o sentimento nacionalista. Vale apontar que, antes das Ordenações Afonsinas, eram utilizados vários códigos, tanto o Romano, o Canônico, como as Leis de Siete Partidas ${ }^{200}$, legislação essa vigente em Castela. Essa interpretação, apontada por José Domingues, é corroborada pela análise de Candido Mendes de Almeida, quando afirma que

a independência de Portugal dos Reinos visinhos de Leão e de Castella ainda não reputava completa, se a Legislação desses Paizes não fosse inteiramente abandonada, proscrita; organisando-se um Codigo Nacional, puramente Portuguez, o ideal dos Juristas patriotas ou revolucionarios. ${ }^{201}$

As Ordenações Afonsinas são divididas em 5 livros, cada um com uma temática específica. De acordo com Ignacio Poveda, essa divisão "parece seguir a estrutura das Decretrais de Gregório $I X$, que tiveram servido de modelo"'202, denotando uma evidente influência que o Direito Canônico exerceu no início das codificações portuguesas.

O Livro I refere-se à administração real e municipal, apontando a organização das instituições e as atribuições de cada cargo. O Livro II refere-se às relações entre a Coroa e a Igreja, questão essa extremamente complexa, visto que não havia separação entre nação, religião e atuação papal. Contexto que faz com que o livro seja confuso em sua redação, com itens muitas vezes

199 José Domingues. Ordenações Afonsinas. Coimbra: Almedina, 2009, p. 58.

200 Las siete partidas del sabio Rey don Alonso el nono: nuevamente glosadas por el Licenciado Gregorio López del Consejo Real de Indias de su Magestad. Madrid: Boletin Oficial del Estado, 1974, 3 vol.

201 Cândido Mendes de Almeida. Os Códigos Portuguezes - Affonsino, Manoelino, Sebastianico e Philippino. Ordenações Filipinas. Rio de Janeiro: Inst. Philomathico, 1870, p. XIX.

202 Ignacio M. Poveda Velasco. Ordenações do Reino. Revista da Faculdade de Direito da Universidade de São Paulo. São Paulo, v. 89, jan/dez, 1994, p. 18. 
contraditórios, denotando que não havia legitimação clara para o Estado abordar questões espirituais, levando Marcelo Caetano concluir que o citado livro é "muito heterogêneo, dificilmente se podendo encontrar nexo lógico entre as matérias nele contidas" ${ }^{203}$. Apesar de procurar com as Ordenações demonstrar autonomia frente à Castela, de acordo com José Domingues,

como filho obediente aos mandamentos da Santa Madre Igreja, rei católico e fiel cristão, o monarca estabelece por lei e manda guardar os privilégios e liberdades que, pelos papas e reis antecessores, tinham sido outorgados à Igreja. $^{204}$

O livro III refere-se à ordem judiciária e da regulamentação dos termos do processo. O livro IV, por sua vez, é dedicado ao direito substantivo e ao direito sucessório. E o livro V, segundo José Domingues, “é, de todos, o que menos problemas apresenta, quanto ao seu conteúdo. Os seus títulos versam matéria criminal, substantiva e processual, fazendo jus à tradição das compilações legislativas medievais que deixam sempre o crimen para o final”205.

Em 1521, o rei D. Manuel I promulga as Ordenações Manuelinas, em substituição às Afonsinas. A compilação de um novo código deu-se pela necessidade de incorporar elementos que até então não faziam parte da preocupação jurídica portuguesa, tais como as legislações extravagantes de seu reinado e do anterior, além da mudança de status da administração e economia de Portugal, passando de um reino peninsular para um Império marítimo.

As Ordenações Manuelinas tiveram uma divulgação maior do que a anterior, devido ao fato das novas ordenações serem impressas. Acompanhando as possibilidades permitidas pelo desenvolvimento tecnológico, o rei promulgou que "dentro de 3 meses os concelhos adquirissem as Novas Ordenações" ${ }^{206}$.

203 Marcelo Caetano. História do direito português (sec. XII-XVI), seguida de subsídios para a história das fontes de direito em Portugal do séc. XVI. Lisboa / São Paulo: Verbo, 2000, p. 539.

204 José Domingues. op. cit., p. 313.

205 José Domingues. op. cit., p. 491.

206 Ignacio M. Poveda Velasco. op. cit., p. 22. 
Tal situação de maior presença da legislação geral nos conselhos leva John Gilissen afirmar que, no século XVI, “a lei escrita suplanta o costume oral; e este mesmo é objecto de uma redução sistemática a escrito. $\mathrm{O}$ processo escrito suplanta o processo oral; a prova escrita é preferida à prova testemunhal"'207.

Porém, a interpretação da substituição do costume pela lei presumindo que há uma oposição entre as duas esferas, nos fornece uma visão parcial da questão. Devemos levar em consideração que há uma relação de contribuição entre costume e lei escrita, que um elemento contribui para o desenvolvimento do outro. Dessa forma, como afirma Marcelo Caetano,

\begin{abstract}
o mero uso corrente dos costumes e sua prática generalizada, não chegam para criar o Direito: é preciso que quem detém o Poder no grupo social imponha a sua obrigatoriedade mediante a aplicação de sanções por considerar a regra indispensável para que reine a justiça ou exista segurança. ${ }^{208}$
\end{abstract}

Ou seja, o costume precisa ser sancionado pelo poder para tornar-se lei, mas a lei não reina soberana, acima das relações sociais. Há esforços de mudanças das leis, de adequá-las às novas demandas da sociedade, ponto esse que denota a evidente influência dos costumes dessa sociedade na formulação do corpus jurídico.

Apesar da mudança em relação à divulgação, as Ordenações Manuelinas não apresentam mudanças substanciais, ocorrendo atualizações de artigos motivadas por alterações e novas demandas administrativas. Há, segundo Ignacio Poveda, alterações no estilo redacional, alterando o estilo compilatório, característico das Ordenações Afonsinas, para um estilo mais decretório ${ }^{209}$. Não há, contudo, alteração na estrutura das Ordenações, mantendo-se a organização em 5 livros e a divisão dos livros em temas, tais como a legislação anterior.

207 John Gilissen. Introdução histórica ao direito. $5^{\mathrm{a}}$ ed. Lisboa: Calouste Gulbenkian, 2008, p. 248. 
Em 1603, o rei Filipe I de Portugal promulga um novo código, denominado Ordenações Filipinas. A nova compilação não "se trata de obra inovadora. No fundo, a preocupação principal foi reunir, num mesmo texto, as Ordenações Manuelinas, a Coleção de Duarte Nunes do Leão e as leis posteriores" ${ }^{210}$. Seguindo a mesma tendência verificada com as Ordenações anteriores, as Filipinas representam um esforço de atualização das normas de acordo com as mudanças sociais. Tal situação torna-se necessária devido à estrutura geral das Ordenações e do pensamento jurídico português na época. As leis gerais são produto da compilação de costumes e não correspondem, grosso modo, à uma formulação racional da estrutura do Estado. Essa situação é a principal diferença entre Ordenações do Reino e as legislações racionalistas do século XVIII e as liberais do século XX.

Com a nova compilação, Filipe I não altera a estrutura das Ordenações, visto que como governante da Coroa de Castela que incorporou Portugal por meio de uma questão sucessória em 1580, evita desgastes maiores com a nobreza lusitana. É interessante notar que, conforme apontamos anteriormente, a compilação das Ordenações Afonsinas foi resultado de um processo de autonomia jurídica portuguesa diante da utilização das Leis das Siete Partidas, legislação de Castela, como direito subsidiário em Portugal.

Dessa forma, não iria Filipe I indispor-se com a nobreza portuguesa e seus magistrados impondo sua legislação, visto que prometera respeitar as instituições de Portugal e garantir autonomia em sua administração ${ }^{211}$.

\section{Fontes do direito subsidiário}

Para uma melhor compreensão das fontes do Direito, é necessário abordar a problemática do

210 Ignacio M. Poveda Velasco. op. cit., p. 24.

211 Para o período denominado de União Ibérica, ver Eduardo D'Oliveira França. Portugal na época da restauração. São Paulo: Hucitec, 1997. 
direito subsidiário. O período após as Ordenações Afonsinas, em que o direito escrito prevalece sobre as tradições e costumes, é marcado por um rápido crescimento do número de leis, alvarás e decretos régios, levando a um confronto entre diversos sistemas jurídicos. Segundo Mário Reis Marques, "no período do direito consuetudinário, dada a natureza deste direito, os juízes não se dão conta da existência de lacunas. O costume consubstancia todo o direito. A noção de lacuna é quase intangível ${ }^{212}$.

Fontes de direito, anteriores à criação do direito pátrio escrito, representado pelas Ordenações, comuns à tradição jurídica portuguesa eram o Direito Justinianeu, Código Canônico e legislações estrangeiras. As esferas de atuação de cada código não são bem definidas e suas utilizações diante das omissões da lei escrita precisam ser problematizadas a fim de compreendermos a dimensão da justiça na Época Moderna.

Para as Ordenações Afonsinas, no caso de ausência de resposta das fontes imediatas, recorrer-se-ia então para o direito subsidiário. Segundo o título VIII do livro II, “(...) quando o caso, de que se trauta, nom for determinado per Ley do Regno, mandamos que seja julgado, e findo pelas Leyx Imperiaaes, e pelos Santos Canones" ${ }^{213}$. Portanto, as Ordenações remetem, pois, em um primeiro momento, para os direitos romano e canônico.

Para o caso de conflito entre as leis imperais e os Santos Cânones,

e acontecendo, que acerca de tal caso as Leyx Imperiaaes sejam contrairas aos Canones, mandamos que assy nas cousas temporaes, como espirituaes, se guardem os Canones, se o caso tal for, que guardando as Leyx Imperiaaes, traga pecado; (...) e no caso temporal, que a guarda das Leyx Imperiaaes nom traga peccado, ellas devem seer guardadas nom embargante que os Canones sejam em contraira disposiçom. ${ }^{214}$

Diante desse trecho, Marques conclui que o "critério do pecado é assim um critério 
intransponível. A transgressão da moral religiosa ou das leis divinas está vedada ao julgador. Este deve 'obediencia ao Padre Eterno, e aa Santa Igreja'. É esta obediência que justifica teoricamente o recurso ao direito canônico"’215.

Para os casos omissos, ou seja, que não há relatos nem no direito romano nem no canônico,

há então que recorrer à Glosa de Acúrsio $^{216} \mathrm{e}$, sendo esta omissa, à opinião de Bártolo, ainda que os 'outros Doutores' defendam posições antinómicas. A preferência atribuída a Bártolo é justificada expressamente: a) por ser a prática seguida nos reinados de D. João I e de D. Duarte; b) por existir uma presunção generalizada da superior racionalidade da opinio do caput scholae dos comentadores; c) e, finalmente, por existir a convicção de que os textos de Bártolo são um útil pólo de certificação do direito, um obstáculo às divergências jurisprudencionais. ${ }^{217}$

A preferência pelos comentários de Bártolo pode ser verificada no próprio texto das Ordenações:

E se for o caso, de que se truta em pratica nom fosse determinado per Ley do Regno, ou estillo, ou costume suso dito ou Leyx Imperiaaes, ou Santos Canones, entam mandamos que se guarde as grosas d'Acursio encorporadas nas ditas Leys. E quando pelas ditas grosas o caso nom for determinado, mandamos, que se guarde a opiniom de Bartholo, nõ embargante, que os outros Doutores diguam o contrairo. ${ }^{218}$

E, em último caso, quando não se encontrar solução nos comentários de Bártolo e das

215 Mário Reis Marques. op. cit., p. 78.

216 De acordo com Gomes da Silva, "por glosa, entendia-se a simples explicação gramatical, de caráter exegético, de palavras ou frases que suscitassem escolhos na sua interpretação; frente a textos [de tradição jurídica romana] que se acham escritos num latim que não é a língua dos tempos medievais, a primeira dificuldade está no compreender o sentido literal desses textos”. Nuno Gonçalo Gomes da Silva. História do direito português: fontes de direito.

Lisboa: Calouste Gulbenkian, 2006, p. 216. Para maiores informações sobre as glosas de Acúrsio e comentários de Bártolo, ver Nuno Gonçalo Gomes da Silva. op. cit., p. 228-9 e p. 244-6.

217 Mário Reis Marques. op. cit., p. 79.

218 Ordenações Afonsinas, liv. II, tít. VIII, item 2. 
demais fontes acima mencionadas, "em ambas as situações o caso deveria ser remetido à corte para que o monarca decida. A norma a observar no caso pendente é posteriormente estendida por analogia a todos os outros casos análogos supervinientes" ${ }^{219}$. Criando-se, dessa forma, uma outra fonte do direito subsidiário, composto da jurisprudência de casos resolvidos pelo rei.

Em relação as Ordenações Manuelinas, Braga da Cruz afirma, em relação ao direito subsidiário que

as Ordenações Manuelinas, na sua primeira versão, impressa de 1512 a 1514, mantêm-se ainda muito próximas das Ordenações Afonsinas no que respeita ao direito subsidiário. Reportamo-nos ao tit. $3^{\circ}$ do livro $\mathrm{II}^{220}$. Para além de reproduzirem a mesma epígrafe ('Quando a ley contradiz aa decretal qual dellas se deve guardar'), ainda se conserva a distinção entre problemas jurídicos de ordem temporal (neste caso recorre-se ao direito romano ou, em matéria que envolva pecado, ao direito canónico). ${ }^{221}$

Conforme notamos na epígrafe do título V do livro II, “como se julgaram os casos que nom forem determinados por Nossas Ordenaçoens" a questão do conflito de jurisidições entre temporal e espiritual perde sua posição de centralidade. Cai, segundo Reis Marques, “a anterior distinção entre problemas de ordem temporal e problemas de ordem espiritual, como critério para a aplicação do direito romano ou do direito canônico, para ser tudo reconduzido ao critério do pecado"222. De acordo com as Ordenações Manuelinas,

quando o caso de que trauta nom for determinado por Ley, Estylo, ou Custume do Reyno, Mandamos que seja julgado, sendo materia que tragua peccado, por os Santos Canones; e sendo materia que nom traga peccado,

219 Mário Reis Marques. op. cit., p. 79.

220 De acordo com a versão das Ordenações Manuelinas, disponível no site http://www.ci.uc.pt/ihti/proj/manuelinas, acesso em 25/04/2010, o título referente ao direito subsidiário é o tít. V e não o III.

221 G. Braga da Cruz. O direito subsidiário na história do direito português. In: Obras esparsas. Coimbra: Universidade de Coimbra, 1981, vol. II, p. 308.

222 Mário Reis Marques. op. cit., p. 80. 
Mandamos que seja julguado polas Leys Imperiaes, posto que os Santos Canones determinem o contrairo...223

Outra alteração das Ordenações Manuelinas em relação às Afonsinas diz respeito à justificativa de utilização do Direito Romano como fonte subsidiária. Passam de referência para a $a$ justiça, tal como ocorreu durante o período dos comentadores, para uma utilização baseada na qualidade de seu texto. Ao título V do livro II das Ordenações Manuelinas, afirma que as "Leys Imperiaes Mandamos soomente guardar pola boa razam que sam fundadas"224. Sublinha-se, portanto, "a ideia de que a obediência ao direito romano assenta na razão natural ou justa razão em que é fundado e não num vínculo ao Império ('iurisdictio Imperii')’225.

Ainda em relação às alterações entre as referidas Ordenações, Reis Marques conclui que

quer Acúrsio, quer Bártolo passam a ser tutelados pela 'comum opiniam dos Doutores'. Este critério doutrinal, extraído dum jogo interpretativo democrático, originado no meio aristocrático dos juristas, passa a prevalecer sobre a exegese da Glosa e sobre o pensamento do mais importante representante da Escola dos Comentadores. ${ }^{226}$

Na compilação das Ordenações Filipinas, em 1603, não verificamos grandes alterações. Em relação ao direito subsidiário, contudo, Reis Marques apresenta uma mudança substantiva,

a passagem do título em causa do Livro II das Ordenações para o Livro III (tít. LXIV), destinado ao direito processual. O facto explica-se pela tomada de consciência do legislador, que se vislumbra já na renovada epígrafe do tít. V do Livro II das Ordenações Manuelinas, de que o problema das lacunas transcende a questão dum conflito de jurisdição entre o poder temporal e o

223 Ordenações Manuelinas, liv. II, tít. V.

224 Ordenações Manuelinas, liv. II, tít. V. 
poder eclesiástico. ${ }^{227}$

Sobre a problemática do direito subsidiário, Reis Marques conclui que "para a nova mentalidade jurídica, o preenchimento das lacunas é uma questão técnico-jurídica intimamente ligada ao acto de julgar"228. Isto é, o direito subsidiário nos informa, também sobre o processo de prevalência do poder temporal sobre o secular, indica uma maior autonomização do pensamento jurídico a partir do século XVII, em que há a liberação dos comentadores medievais e uma maior reflexão sobre a filosofia do direito.

\section{Direito Português em aplicação nas áreas coloniais}

A historiografia sobre o direito lusitano é basicamente influenciada pela produção portuguesa. Podemos citar as obras de António Manuel Hespanha ${ }^{229}$, Marcelo Caetano ${ }^{230}$ e Nuno Espinosa Gomes da Silva ${ }^{231}$, como exemplo de reflexões preocupadas com o estudo do direito em Portugal. A preocupação principal dessas obras reside na reflexão sobre a questão jurídica na área continental de Portugal, omitindo, dessa forma, a região das Conquistas.

Em função dessa situação, a pouca produção brasileira sobre o direito ${ }^{232}$ trata as fontes portuguesas como se fossem presentes e atuantes em todas as áreas do Império da mesma forma. Tal modelo ignora as consequências do estabelecimento da empresa colonial e suas especificidades, dando a impressão de que, na organização político-jurídica, o processo de colonização não foi importante para a formação do Brasil.

Discordamos dessa interpretação, pois consideramos que a colonização foi processo

227 Mário Reis Marques. op. cit., p. 83.

228 Mário Reis Marques. op. cit., p. 83.

229 António M. Hespanha. As vésperas do Leviathan. Coimbra: Almedina, 1994.

230 Marcelo Caetano. História do direito português (sec. XII-XVI), seguida de subsídios para a história das fontes de direito em Portugal do séc. XVI. Lisboa / São Paulo: Verbo, 2000.

231 Nuno Espinosa Gomes da Silva. op. cit..

232 Podemos citar o artigo de Ignacio Poveda. As Ordenações do Reino. Revista da Faculdade de Direito da Universidade de São Paulo. São Paulo, v. 89, jan/dez, 1994, p. 11-67. 
marcante das estruturas gerais da colônia em formação. Segundo Florestan Fernandes,

os portugueses transplantaram, para cá, a ordem social que tinha vigência em Portugal na época dos Descobrimentos e da Conquista. O que quer dizer que ocorreu uma formidável tentativa deliberada de preservação e de adaptação de todo um corpo de instituições e de padrões organizatórios-chaves, com vistas à criação de um 'novo Portugal'(expressão empregada pelo padre Cardim com referência a São Vicente) que deveria emergir das condições sociais de vida de uma colônia de exploração. ${ }^{233}$

Seguindo a interpretação de que a colonização foi um processo de adaptação das estruturas originárias de Portugal para uma nova realidade, não podemos ignorar que a aplicação do direito comum português nas colônias passou por uma intermediação.

Em obra de 1936, César Trípoli, ao escrever o ensaio sobre a evolução do direito no Brasil, afirma que "era impossível aplicar no Brasil as Ordenações do Reino, de modo integral; era impossível transplantar ás terras inexploradas e sem limites, do Brasil do século XVI, as leis e instituições de Portugal." ${ }^{234}$

E, para tanto, define o termo "direito colonial português" como leis de organização política, administrativa e militar da colônia, direito esse baseado nos "usos e costumes, que tivessem sido importados de Portugal pelos colonos, quer por estes adotados, adquiridos dos índios." ${ }^{235}$.

Compartilhamos dessa interpretação, pois a mesma contempla as relações estabelecidas na colônia e, ao contrário da historiografia portuguesa, que estabelece as relações político-jurídica na dicotomia poder central e poder local. Oposição essa definida por António Hespanha e M. Cristina Santos como elemento para questionar a centralização do Império ao afirmarem que "o modelo de um poder absoluto, isto é, não dividido no plano externo cede perante a uma multiplicidade de

233 Florestan Fernandes. Circuito fechado, quatro ensaios sobre o 'poder institucional'. São Paulo: Hucitec, 1977, p. 31-32.

234 César Trípoli. História do direito português (ensaio). Rio de Janeiro, vol. I (época colonial), 1936, p. 47.

235 César Trípoli. op. cit., p. 51. 
sistemas práticos, onde o poder da coroa portuguesa convive com os poderes locais" ${ }^{236}$.

Essa multiplicidade de sistemas práticos, em um primeiro momento, pode dar a impressão de que há uma ampla autonomia no Império, situação essa que poderia ser intensificada nas intermediações do direito colonial português. Porém, para o caso de estabelecimento da administração colonial no Brasil, Rodrigo Ricupero afirma que, apesar dos poderes locais e informais, o poder da Coroa estava presente, mesmo nas etapas iniciais da colonização.

Segundo Ricupero,

podemos pensar a administração colonial, ou seja, a estrutura burocrática que ia dos governadores-gerais aos funcionários subalternos da justiça e da fazenda espalhados pelas diversas capitanias, como o núcleo formal do governo da conquista. Este, por sua vez, abrangeria também outras esferas formais, por exemplo, os membros das câmaras municipais, ou informais, os responsáveis pelas tarefas bélicas que surgiam a todo momento, feitas, porém, sob o controle com mandato da própria administração colonial. ${ }^{237}$

Continuando a evolução das estruturas administrativas,

a constituição do Governo-Geral acarretou duas conseqüências importantes. A primeira foi a alteração da forma descentralizada vigente nos primeiros anos da colonização, e a segunda, em parte decorrente da primeira, um substancial desenvolvimento da administração colonial, que ganhou maior complexidade com o surgimento de diversos órgãos e cargos. ${ }^{238}$

Para o período anterior ao Governo Geral, "as cartas de doação e os forais das capitanias constituem, como é sabido, a principal fonte para o conhecimento do regime jurídico do Brasil no

236 António M. Hespanha e M. Cristina Santos. Os poderes num império oceânico. In MATTOSO, José (org.). História de Portugal. Lisboa: Estampa. 199-, p. 404.

237 Rodrigo Ricupero. A formação da elite colonial. São Paulo: Alameda, 2009, p. 139.

238 Rodrigo Ricupero. op. cit., p. 138. 
período anterior"239. De acordo com António Vasconcelos de Saldanha, "outro dos pontos de registro obrigatório de legislação foram os livros ou tombos das Câmaras das Capitanias. Capítulos, provisões, alvarás, doações, instruções, autos, de tudo convêm um pouco esses valiosíssimos repositórios" ${ }^{240}$.

Marcos Carneiro de Mendonça, em prefácio da obra Raizes da formação administrativa do Brasil, em que apresenta a transcrição de documentos coloniais, em relação ao Regimento de Tomé de Sousa, afirma que

na ordem da importância atribuída, pelo consenso geral dos historiadores, e a primeira Constituição Brasileira. O seu exame, em confronto com os forais das Capitanias a ele anteriores e as Ordenações, Provisões e Alvarás portugueses vigentes no Brasil àquela época mostra que, se nele há fonte de conhecimento das condições gerais e econômicas do meio brasileiro e das preocupações e interesses da Coroa por suas grandes e pouco conhecidas processões de além-mar, não há originalidade nas medidas adotadas. ${ }^{241}$

\section{Direito português em aplicação local}

Nos municípios, a justiça e outras funções a ela ligadas eram atribuições dos oficiais da Câmara. Esses eram compostos, para esses casos, de juízes ordinários "não letrados, eleitos pelos povos de acordo com processo previsto nas Ordenações e não remunerados"242. Em oposição a esses, havia os juízes de fora, letrados e de nomeação régia. Segundo António M. Hespanha, os juízes de fora e os corregedores, por representarem um esforço de centralização, são considerados

239 M. Paulo Merêa. A solução tradicional da colonização portuguesa no Brasil. In: História da Colonização Portuguesa no Brasil. Edição Monumental Comemorativa do Primeiro Centenário da Independência do Brasil. Porto: Litografia Nacional, tomo II, 1921, p. 174.

240 António Vasconcelos de Saldanha. As capitanias. O regime senhorial na Expansão Ultramarina Portuguesa. Funchal: CEHA, 1992, p. 39.

241 Marcos Carneiro de Mendonça. Raízes da formação administrativa do Brasil. tomo I, Rio de Janeiro: IHGB, 1972 , p. 31.

242 António M. Hespanha. História de Portugal moderno: político e institucional. Universidade Aberta: Lisboa, 1995. p. 164. 
"os pivots periféricos da administração real”"243.

Os juízes ordinários, mais presentes nos municípios ${ }^{244}$, para além das funções de administração da justiça,

tinham atribuições no domínio da manutenção da $\operatorname{ordem}^{245}$, da defesa da jurisdição real ${ }^{246}$, da contensão dos abusos dos poderosos ${ }^{247}$, da polícia (das estalagens $^{248}$, das batidas aos $\operatorname{lobos}^{249}$ ); para além de deverem assistir os vereadores e almotacés ${ }^{250}$ no exercício da sua jurisdição especial em casos de injúrias a almotacés. ${ }^{251}$.

Nuno Espinosa Gomes da Silva, ao tratar do período anterior às Ordenações Afonsinas e posterior à fundação de Portugal, denomina-o de "período de direito consuetudinário e foraleiro". Tal denominação se dá pelo fato do direito predominante ser estabelecido pelos forais de fundação das vilas e cidades. Segundo Gomes da Silva,

a autoridade do costume, neste período, é abertamente reconhecida pelo poder central. $\mathrm{Na}$ concessão de forais é frequente o remeter-se para o costume da terra, para o forum, mos, ou usus terrae, e numa doação de Sancho I, em 1191, diz-se expressamente - 'Qum consuetudine, que pro lege suscipitur' frase muito comum nos documentos do tempo. ${ }^{252}$

Apesar do aparente particularismo, no que se refere ao respeito do costume da terra, o autor

243 António M. Hespanha. op. cit., p. 163.

244 Nuno Gonçalo Monteiro afirma que, em meados do séc. XVII, apenas $8 \%$ dos concelhos contavam com juízes de fora e, durante a segunda metade do séc. XVIII, o número, embora tenha crescido, nunca ultrapassou os $20 \%$ dos concelhos em Portugal continental. Nuno Gonçalo Monteiro. As comunidades territoriais. In: MATTOSO, José (coord.). História de Portugal. Lisboa: Estampa, 1994, vol. V, p. 310.

245 Ordenações Filipinas, liv. I, item 63, n 3ss, 13 a 15 e 39ss.

246 Idem, liv. I, item 68, n. 16.

247 Idem, liv. I, item 68, n. 17.

248 Idem, liv. I, item 68, n. 20.

249 Idem, liv. I, item 68, n. 21.

250 Idem, liv. I, item 58, n. 23ss.

251 António M. Hespanha, op. cit., p. 163.

252 Nuno Espinosa Gomes da Silva. op. cit., p. 167. 
conclui que por "trás da diversidade dos costumes locais, os forais apresentam um fundo comum, uma relativa unidade" 253 .

Em relação ao conteúdo dos forais, "se examinarmos os, aliás, pouco numerosos foros e costumes municipais que chegaram até nós ${ }^{254}$, verificaremos que, de um modo geral, são pequenos códigos que se propõe abarcar a vida local, quer de carácter jurídico-político, quer privado." 255 .

O período posterior às Ordenações Afonsinas, é denominado por Gomes da Silva de "Período de Influência do Direito Comum", isto é, momento esse que há o início de um processo de centralização jurídica, em que o rei concentra uma maior atuação jurídica. Passa de árbitro entre as várias fontes do direito para o papel de rei legislador, ou seja, aquele que escreve as leis.

Apesar do esforço de centralização,

no tempo de D. Afonso III e D. Dinis são, ainda, numerosas as concessões de foral. Posteriormente, todavia, começam a rarear. Agora, os povos, para solução de dificuldades, fazem os seus agravos em Cortes, e o monarca, em resposta, toma providências destinadas a actuar nos casos apresentados, providências essas que, muitas vezes, vão modificar o conteúdo de préexistentes forais. De qualquer modo, no âmbito local, são, ainda, os forais a principal fonte de direito. ${ }^{256}$

Nas primeiras décadas do século XVI, o rei inicia reformas nos forais,

por um lado, com o correr dos tempos, tinham sido promulgadas muitas leis gerais que haviam revogado grande parte do conteúdo dos velhos forais. Por outro lado, a parte dos forais, não revogada, estava, em absoluto, desactualizada, já porque, no respeitante a prestações e isenções tributárias, se tornava difícil a sua aplicação, em virtude de datarem de há alguns séculos

253 Nuno Espinosa Gomes da Silva. op. cit., p. 169.

254 Os foros e costumes municipais portugueses podem consultar-se na Collecção de Livros Inéditos de História Portuguesa, tomos IV e V e no Portugaliae Monumenta Historica, Leges et Consuetudines, vol. I e II. Acesso em http://www.irib.org.br/portugaliae/index.asp, disponível em 25/04/2010.

255 Nuno Espinosa Gomes da Silva. op. cit., p. 170.

256 Nuno Espinosa Gomes da Silva. op. cit., p. 273-274. 
e se concretizarem em pesos, medidas e moedas fora de uso, já porque as constantes depreciações da moeda, e a legislação de expediente criada para actualizar o valor das prestações, gerava explicável confusão. ${ }^{257}$

Com a reforma dos forais, a justiça local passa a ser regulada pelas Ordenações do Reino. Há, contudo, uma limitação de atuação, visto que os forais eram considerados cartas de privilégios concedidas às vilas e cidades.

A atuação da justiça, na esfera local, passa a ser estabelecida pelas Posturas da Câmara, conjunto de regras que organizavam a vida quotidiana, as relações econômicas e aspectos religiosos. As Posturas eram decididas, por sua vez, nos concelhos e registradas nas Atas da Câmara dos respectivos municípios.

António M. Hespanha, ao tratar da atuação dos oficiais municipais afirma que os mesmos “tinham uma área autónoma de competência prevista na lei e garantida pelo direito contra a usurpação" ${ }^{258}$.

Mesmo observando as Ordenações Filipinas, verificamos que competia aos oficiais ter o

carrego de todo o regimento da terra [...], porque a terra e os moradores dela possam bem viver" 259 e especificando depois que "proverão as posturas, vereações e costumes antigos da cidade, ou villa; e as que virem são boas, segundo o tempo, façam as guardar, e as outras emendar. E façam de novo as que cumprir ao prol e bom regimento da terra. ${ }^{260}$

Verificamos que, para o período entre os séculos XII e XVI, em que o rei concedia forais aos municípios portugueses, isto é, cartas de privilégios que asseguravam plena autonomia ${ }^{261}$.

257 Nuno Espinosa Gomes da Silva. op. cit., p. 344.

258 António M. Hespanha. História de Portugal moderno: político institucional. Lisboa: Universidade Aberta, 1995, p. 163.

259 Ordenações Filipinas, liv. I, tít. LXVI.

260 Idem, liv. I, tít. LXVI, item 28.

261 Os forais de D. Afonso III acham-se publicados no Portugaliae Monumenta Historica, Leges et Consuetudines, vol. I e II. Os posteriores e, bem assim, as modificações introduzidas nos existentes, encontram-se, ainda, na sua quase totalidade inéditos. Para a discussão sobre os forais velhos, ver Antonio Henrique de Oliveira Marques. Guia do 
Após o reinado de D. Dinis I, conforme apresentamos anteriormente, as cartas de foral praticamente desapareceram. A partir de 1446, os direitos dos concelhos passam a ser regulados pelas Ordenações Afonsinas.

Essa mudança, além de demonstrar um esforço de padronização dos direitos dos municípios portugueses, ilustra um esforço, por parte do monarca, em restringir os privilégios locais. Os direitos concedidos pelas cartas de foral não foram anulados, mas surgiram várias propostas de reforma dos mesmos. Gomes da Silva aponta que "a Carta Régia de 15 de dezembro de 1481, ordenara que, de Janeiro a Outubro de 1483, fossem remetidos todos os forais do Reino; os que não fossem, deixariam de ter validade" ${ }^{262}$. E, em 1520 , terminou a obra de reforma dos forais e

estes forais reformados por D. Manuel, chamados de forais novos ${ }^{263}$ ou manuelinos, e que deixaram de conter normas respeitantes à administração, ao direito e processo civil e penal - matérias essas, agora versadas na legislação geral - passam, assim, a regular, apenas residualmente, os encargos e prestações devidos pelos concelhos ao rei ou aos senhores. ${ }^{264}$

O rei, que passa a assumir o papel de legislador com a criação das Ordenações do Reino, assegura para si o controle de alterar as leis visando garantir o bem comum. Segundo o texto do Livro III das Ordenações Afonsinas, "o Rey he Ley animada sobre a terra, e pode fazer Ley, e reuogala, quando viir que cumpre de se assi fazer"265.

Dessa forma, os usos e costumes locais continuam a ser respeitados pela administração real. Porém, essa autonomia é relativizada pela ação do rei através da defesa do bem comum.

Para os municípios na América Portuguesa, a situação apresenta outros fatores, pois são para Edmundo Zenha como "humildes vilas brasileiras, lamparinas de civilização que o português

estudante de história medieval. Cosmos: Lisboa, 1964, p. 177.

262 Nuno Espinosa Gomes da Silva. op. cit., p. 345.

263 Os forais anteriores são denominados velhos e os poucos concedidos posteriormente a esta reforma são chamados novíssimos.

264 Nuno Espinosa Gomes da Silva. op. cit., p. 346-347.

265 Ordenações Afonsinas, liv. III, tít. LX, item I. 
acendia pela costa imensa" 266 , pelo fato de serem as vilas e cidades a mais estável e perene estrutura administrativa na colônia, que perpassa os períodos das Capitanias, Governo-Geral, Vice-Reinado, e, mesmo com limitações de atribuições ${ }^{267}$, ultrapassa a Independência.

As vilas, em meio a um território desconhecido e a desbravar, levam-nos a considerar a estrutura administrativa, a fidelidade às instituições portuguesas e, mais notadamente, à figura do rei, como uma garantia que o colono tinha de afirmar-se como português, representante da civilização cristã, em oposição à visão de barbárie das sociedades indígenas.

Tal sentimento de pertencimento à sociedade europeia pode ser observado nas Memórias para a História da Capitania de S. Vicente, publicado em 1797. Frei Gaspar da Madre de Deus, nascido na vila de S. Vicente em 1715, compartilha a interpretação de que a fidelidade ao rei é fundamental para o colono. Afirma que,

S. Paulo, desde a sua fundação até hoje, nunca reconheceu outro Soberano senão dos Senhores Reis de Portugal, os quais, não obstante ser sujeita a Donatário a Capitania de S. Vicente, sempre tiveram o Supremo Domínio nela: por isso os seus moradores nunca observaram leis diversas das gerais para toda a Monarquia que deu El-Rei D. João III. Além disso, davam obediência aos Donatários e também aos Capitães-mores e Ouvidores nomeados por eles ou por quem tinha jurisdição para isso. Estes Capitãesmores e Ouvidores registravam as suas Patentes e tomavam posse na Câmara da Vila Capital da Capitania e nada mais era necessário para serem obedecidos na de S. Paulo e nas mais Povoações de Serra acima, que se foram fundando. ${ }^{268}$

266 Edmundo Zenha. O municipio no Brasil. São Paulo: I.P.E., 1948, p. 25.

267 Limitações político-administrativas definidas pelo Ato Adicional de 1828 que regula as atribuições que competem aos municípios, segundo Edmundo Zenha, essas mudanças transformam os municípios em "corporações meramente administrativas". Lei de 1 de Outubro de 1828 “dá nova forma ás Camaras municipaes, marca suas attribuições”. Para o texto do Ato Adicional, conferir BRASIL. Colleção das Leis do Imperio do Brazil: 1828. parte primeira. Rio de Janeiro: Typographia Nacional, 1878.

268 Frei Gaspar da Madre de Deus. Memórias para a História da Capitania de S. Vicente, hoje chamada de S. Paulo. São Paulo: Comissão do IV Centenário da cidade de São Paulo, 1954, p. 136-137. 


\section{Capítulo 2}

\section{Fontes e Bancos de Dados}

L'historie d'aujourd'hui se trouve obligué à renoncer à la naïveté méthodologique et à réfléchir aux conditions d'etablissement de son savoir. L'ordinateur lui em donne le loisir, en le libérant de ce qui occupait jusqu'ici l'essentiel de son temps, la collecte des données sur ses fiches. Mais il le contraint, em revanche, à un travail préable sur l'organisation des séries de données et sur leur signification par rapport à ce qu'il cherche. Comme toutes les sciences sociales, mais peut-être avec un peu de retard, l'histoire d'aujord'hui passe de l'implicite à l'explicite. Le codage des données suppose leur définition; leur définition implique un certain nombre de choix et d'hypothèses d'autant plus consciences qu'il faut les penser em fonction de la logique d'un programme. Ansi tombe définitivement le masque d'une objectiveté historique qui se trouverait cachée dans les 'faits' et découverte em même temps qu'eux; l'histoire ne peut plus échapper à la conscience qu'il a contruit ses 'faits', et que l'objectivité de sa recherche tient non seulement à l'emploi de procédures correctes dans l'élaboration et le traitement de ces 'faits', mais à leur pertinence par rapport aux hypothèses de sa recherche.

L'histoire sérielle n'est donc pas seulement, ni surtout, une transformation du matériau historique. C'est un révolution de la conscience historiographique.

François Furet ${ }^{269}$

269 François Furet. L'histoire quantitative et la construction du fait historique. Annales. Économies, Sociétés, Civilisations. Paris, 1971, v. 26, n. 1, p. 70-71. 
Nesse capítulo iremos abordar as fontes e o Banco de Dados. Para tanto, trataremos das fontes consultadas, como as Atas da Câmara de São Paulo, Cartas de Datas de Terra, Registro Geral da Câmara de São Paulo e trabalhos genealógicos, tais como a Nobiliarquia paulistana de Pedro Taques de Almeida Paes Leme e a Genealogista paulistana de Luiz Gonzaga da Silva Leme. Após essas reflexões, iremos construir um panorama da discussão sobre história quantitativa, seus métodos e suas características. E, a partir dessas informações, estabeleceremos as problemáticas que guiaram a elaboração do Banco de Dados.

Por fim, apresentamos os resultados obtidos através da análise quantitativa do Banco de Dados, por meio do aplicativo SPSS.

\section{1 - Fontes}

\section{Atas da Câmara de São Paulo}

As Atas da Câmara correspondem ao registro das sessões dos oficiais. Nelas são escritos os assuntos discutidos, as decisões e posturas referentes à administração municipal.

Para o município de São Paulo, encontramos as Atas desde os primeiros anos de existência da vila, o que, segundo Afonso d'Escragnolle Taunay, nos permite um panorama rico e detalhado sobre a vida cotidiana da vila piratiningana ${ }^{270}$.

Obstante a instalação da vila de São Paulo ter ocorrido em 1560, não encontra-se o registro dos primeiros anos, pois o primeiro volume das Atas encontra-se extraviado. De acordo com Manuel Alves de Souza, responsável pela transcrição das atas, conforme veremos adiante, “os cadernos de actas desses dois annos [1560 e 1561] não se encontram hoje [1914] no Archivo 
Municipal, e não se sabe a data do seu desapparecimento",271.

Continua Souza ao declarar que "desappareceram também todas as actas dos annos de 1565 a 1571 , as de 1574 , as de 1596 a 1599 e (...) dos annos de 1577 e 1596 existe apenas uma de cada anno" 272 .

Taunay, em São Paulo nos primeiros anos, afirma que, em relação ao primeiro caderno das Atas, referentes aos dois primeiros anos da vida municipal, "leu-o Azevedo Marques e Cândido Mendes de Almeida também o percorreu antes de 1880. Não há quarenta anos, ainda, foi subtraído o tão precioso livro... após uma permanência de mais de três séculos no arquivo paulistano" 273 .

Em relação à grafia, Taunay afirma que

à primeira vista nem parecem as Atas da Câmara de São Paulo quinhentistas, escritas não em português e sim em idioma lusitaniforme, áspero e grosseiro, em que a grafia extravagante das palavras se une à confusão dos conceitos, às ambigüidades da frase, à ausência de pontuação senão, freqüentemente, de termos indispensáveis à oração $0^{274}$.

Manuel Alves de Souza, responsável pela tarefa de transcrição dos documentos quinhentistas municipais, relata que os mesmos são "de leitura difficil, não só devido ao estado em que se acham, estragados pela traça, como também á calligraphia daquella época e á ortographia dos escrivães da Camara, que escreviam como bem entendiam, graphando na mesma linha, de maneiras diversas" ${ }^{275}$.

As Atas da Câmara de São Paulo foram transcritas e publicadas pela Prefeitura de São Paulo a partir de 1914. No dia 14 de janeiro do mesmo ano, a Câmara Municipal lavrou o contrato com Manuel Alves de Souza ${ }^{276}$ para a "decifração" e publicação das Atas de 1555 a 1826.

271 Actas da Camara de São Paulo. São Paulo: Duprat \& Ca., 1914, vol. I, p. 4.

272 Idem, p. 4.

273 Afonso de Taunay. op. cit., p. 21.

274 Afonso de Taunay. op. cit., p. 21.

275 Actas da Camara de S.to André da Borda do Campo. São Paulo: Duprat \& Ca., 1914, p. 3.

276 Relatório de 1914 apresentado à Câmara Municipal de S. Paulo pelo prefeito Washington Luiz Pereira de Sousa. 
$\mathrm{Na}$ Introdução das Atas, presente no primeiro volume publicado dessas, Manuel Alves de Souza declara que "os 26 primeiros volumes foram decifrados pelo snr. Francisco Escobar, de accordo com um contracto então celebrado com a Presidencia da Camara, e os 27 restantes serão decifrados por mim" 277 .

Na publicação das Atas, a documentação transcrita é procedida de uma relação dos oficiais que, eleitos anualmente, compunham a Câmara. Compõe também a edição uma lista de abreviaturas empregadas pelos escrivães da câmara ${ }^{278}$.

Para o período abarcado para essa pesquisa, entre a instalação do município em 1560 e o governo do Morgado de Mateus e restauração da capitania de São Paulo em 1765, encontramos 15 volumes da edição publicada das Atas. Cada volume encadernado, corresponde, grosso modo, a 500 páginas. Dessa forma, com objetivo de levantar o volume da documentação publicada por período, calculamos a quantidade de anos por edição. Conforme podemos visualizar na tabela 1, quanto menor o número de anos por edição, maior a freqüência de atas publicadas. Consequentemente, quanto maior o número de anos por edição, menor a frequência de atas publicadas.

\begin{tabular}{l|l|l}
\hline \multicolumn{3}{c}{ Tabela 1 - Volume de Atas da Câmara na edição transcrita } \\
\hline Volume & Período & Anos / Edição \\
\hline 1 & $1560-1595$ & 36 \\
2 & $1596-1622$ & 27 \\
3 & $1623-1628$ & 6 \\
4 & $1629-1639$ & 11 \\
5 & $1640-1652$ & 13 \\
6 & $1653-1678$ & 26 \\
7 & $1679-1700$ & 32 \\
8 & $1701-1719$ & 19 \\
9 & $1720-1729$ & 10 \\
10 & $1730-1736$ & 7 \\
\hline
\end{tabular}

São Paulo: Casa Vanorden, 1916, p. 95.

277 Actas da Camara e S.to André da Borda do Campo. p. 3.

278 Cf. Idem, p. 4. 


\begin{tabular}{l|l|l}
11 & $\left|\begin{array}{l}1734-1743 \\
1744-1748 \\
13 \\
14 \\
15\end{array}\right| \begin{array}{l}1749-1755 \\
1756-1764 \\
1765-1770\end{array}$
\end{tabular}

Fonte: Atas da Câmara de São Paulo. São Paulo: Duprat \& C ${ }^{\mathrm{a}}$, 1914-1917, vol. I-XV.

Observamos que, entre os anos de 1653 e 1700, há uma queda significativa de sessões da Câmara publicadas. Porém, tais conclusões não são seguras. Ao realizarmos observações baseadas em edições transcritas, ignoramos fatores importantes, como estado de conservação da documentação original, seu grau de legibilidade e, consequentemente, as dificuldades de transcrição.

Portanto, decidimos verificar a documentação camarária manuscrita. As Atas da Câmara encontram-se sob guarda do Arquivo Histórico Municipal Washington Luís (AHMWL), subordinado à Prefeitura de São Paulo.

Diante da impossibilidade da consulta da documentação original manuscrita, devido à fragilidade e o risco de seu manuseio, optamos por utilizar a edição microfilmada. Entre os anos de 1978 e 1981, o Departamento do Patrimônio Histórico da Secretaria Municipal da Cultura de São Paulo realizou a microfilmagem da documentação sobre administração municipal custodiada no Arquivo.

Não localizamos, contudo, o primeiro rolo de microfilmes (DPH1), correspondente ao período entre 1562 e 1606, no acervo da instituição. Conseguimos as informações referentes à quantidade de folhas por período consultando o Guia Documental do AHMWL ${ }^{279}$ e a Revista do Arquivo Municipal, $n^{\circ} .191^{280}$, correspondente ao catálogo de documentação manuscrita.

279 Arquivo Municipal Washington Luís. Guia do Arquivo Histórico Municipal Washington Luis. São Paulo: DPH, 2007.

280 Revista do Arquivo Municipal. São Paulo: DPH, v. 191, 1992. 
Tabela 2 - Atas da Câmara de São Paulo (1560-1765)

\begin{tabular}{|c|c|c|c|c|}
\hline volume & microfilme & período & folhas & folhas/ano \\
\hline 1 & DPH 1 & $1555-1587$ & & 33 \\
\hline 2 & DPH 1 & $1562-1577$ & & 16 \\
\hline 3 & DPH 1 & $1578-1580$ & & 3 \\
\hline 4 & DPH 1 & $1583-1585$ & & 3 \\
\hline 5 & DPH 1 & $1585-1587$ & & 3 \\
\hline 6 & DPH 1 & $1588-1621$ & & 34 \\
\hline 7 & DPH 1 & $1590-1595$ & & 6 \\
\hline 8 & DPH 1 & $1596-1601$ & & 6 \\
\hline 9 & DPH 1 & $1601-1606$ & & 6 \\
\hline 10 & DPH 2 & $1606-1607$ & 36 & 18.0 \\
\hline 11 & DPH 2 & $1607-1620$ & 150 & 10,7 \\
\hline 12 & DPH 2 & $1622-1625$ & 133 & 33,2 \\
\hline 13 & DPH 2 & $1625-1628$ & 110 & 27,5 \\
\hline 14 & DPH 2 & $1628-1632$ & 96 & 19,2 \\
\hline 15 & DPH 2 & $1632-1634$ & 94 & 31,3 \\
\hline 16 & DPH 3 & $1634-1635$ & 47 & 23,5 \\
\hline 17 & DPH 3 & $1635-1637$ & 98 & 32,6 \\
\hline 18 & DPH 3 & $1637-1639$ & 142 & 47,3 \\
\hline 19 & DPH 3 & $1639-1642$ & 136 & 34 \\
\hline 20 & DPH 3 & $1642-1644$ & 50 & 16,6 \\
\hline 21 & DPH 4 & $1644-1648$ & 88 & 17,6 \\
\hline 22 & DPH 4 & $1648-1651$ & 89 & 22,2 \\
\hline 23 & DPH 4 & $1651-1656$ & 128 & 21,3 \\
\hline $23 a$ & DPH 4 & $1656-1660$ & 118 & 23,6 \\
\hline $23 b$ & DPH 4 & $1660-1664$ & 117 & 23,4 \\
\hline $24 a$ & DPH 4 & $1664-1669$ & 99 & 16,5 \\
\hline $24 b$ & DPH 5 & $1666-1669$ & 96 & 24 \\
\hline 24 & DPH 5 & $1669-1675$ & 139 & 19,8 \\
\hline 25 & DPH 5 & $1675-1682$ & 160 & 20 \\
\hline 26 & DPH 5 & $1682-1690$ & 112 & 12,4 \\
\hline 26 & DPH 6 & $1690-1701$ & 108 & 9 \\
\hline 27 & DPH 6 & $1701-1708$ & 118 & 14,7 \\
\hline 27 & DPH 6 & $1708-1715$ & 119 & 14,8 \\
\hline
\end{tabular}




\begin{tabular}{l|l|l|l|l}
28 & DPH 6 & $1715-1721$ & 137 & 19,5 \\
28 & DPH 7 & $1721-1723$ & 148 & 49,3 \\
29 & DPH 7 & $1723-1726$ & 147 & 36,7 \\
30 & DPH 7 & $1726-1729$ & 150 & 37,5 \\
31 & DPH 7 & $1729-1732$ & 145 & 36,2 \\
32 & DPH 7 & $1732-1736$ & 145 & 36,2 \\
33 & DPH 8 \\
34 & DPH 8 \\
35 & DPH 8 \\
36 & DPH 9 \\
36 & DPH 9 \\
37 & DPH 9 \\
38 & DPH 9 \\
39 & DPH 9 \\
39 & DPH 10 \\
40 & DPH 10 \\
40
\end{tabular}

Fonte: Atas da Câmara de São Paulo. Microfilmes DPH 2 a DPH 10, custodiados no AHMWL.

Verificamos na tabela 2, que o período em que há menor quantidade de documentação refere-se ao período de 1642 a 1721, em que a quantidade de folhas do documento por ano não ultrapassa o limite de 25. Nos períodos anterior e posterior, a relação apresenta-se mais elevada, indicando uma quantidade maior de documentação produzida e, consequentemente, um maior número de sessões camarárias.

Observando o grau de conservação da documentação, vemos que somente para o período entre 1729 e 1745 encontramos alguma dificuldade na leitura do texto. Para o período entre 1736 e 1744, especificamente, a leitura apresenta-se muito difícil.

De maneira geral, cruzando os dados referentes à quantidade de documentação manuscrita e seu grau de legibilidade, observamos que não há um comprometimento substancial do volume 
documental que influenciou no processo de transcrição.

O período que apresenta maiores dificuldades de leitura (devido à conservação e grafia) não corresponde ao período que apontamos como momento de baixa produção documental.

Cruzando, por sua vez, esses dados com informações coletadas na historiografia sobre São Paulo, verificamos que o período corresponde, grosso modo, ao período apontado por Sérgio Buarque de Holanda ${ }^{281}$ como marcado pela fundação de vilas no sertão e pelo esvaziamento demográfico de São Paulo em decorrência da migração à zona mineradora, assuntos que serão desenvolvidos mais adiante, no capítulo 3.3.

\section{Registro Geral da Câmara}

O Registro Geral da Câmara é composto pela documentação diversa produzida e recebida por essa instituição. A documentação publicada é composta por 22 volumes para o período de 1583 a 1766, dentro do período desse estudo.

Enquanto que nas Atas encontramos o registro das sessões da Câmara, no Registro Geral verificamos cartas endereçadas e recebidas pelos oficiais, cópias de cartas e alvarás reais e registros sobre atividades cotidianas da câmara.

O Registro Geral foi transcrito e publicado no período entre 1917 e 1919, pelo Departamento de Cultura da Prefeitura de São Paulo.

A documentação manuscrita, assim como as Atas da Câmara, encontra-se custodiada no Arquivo Histórico Municipal Washington Luís. O acesso aos originais, assim como no caso referente às Atas, foi-nos dificultado.

Ao procurarmos a documentação microfilmada, somente localizamos dois rolos, que representam metade do documentação para o período do estudo. O acervo do Registro Geral

281 Sérgio Buarque de Holanda. Movimentos da população em São Paulo em meados do século XVIII [sic]. Revista do $I E B, \mathrm{n}^{\circ} .1,1966$. 
encontra-se armazenado com os demais documentos do Arquivo, junto não somente com o acervo permanente ${ }^{282}$, mas também junto com sessões recentes da Câmara Municipal de São Paulo, dados de emplacamento de ruas referentes ao século XX e informações sobre investigações de comissões parlmentares de inquérito da instituição.

A tabela 3 demonstra o esforço em estabelecer padrões de frequência e sua relação com a legibilidade do documento, tal como fizemos com as Atas anteriormente. Porém, a amostra documental, limitada a 50\%, não nos permite maiores conclusões, conforme verificamos abaixo.

\section{Tabela 3 - Registro Geral da Câmara de São Paulo (1583-1765)}

\begin{tabular}{|c|c|c|c|}
\hline volume & microfilme & período & folhas \\
\hline 1 & & 1583-1595 & \\
\hline 2 & & 1600-1609 & \\
\hline 3 & & 1616-1618 & \\
\hline 4 & DPH 44 & $1620-1623$ & 71 \\
\hline 5 & DPH 44 & $1623-1625$ & 38 \\
\hline 6 & DPH 44 & 1635 & 42 \\
\hline 7 & DPH 44 & 1636-1639 & 112 \\
\hline 8 & DPH 44 & $1640-1645$ & 44 \\
\hline 9 & DPH 1 & $1646-1653$ & 93 \\
\hline 10 & DPH 1 & $1653-1661$ & 140 \\
\hline 11 & DPH 1 & $1655-1656$ & 176 \\
\hline 12 & DPH 1 & $1675-1688$ & 174 \\
\hline 13 & DPH 1 & $1708-1716$ & 134 \\
\hline 14 & DPH 1 & $1717-1721$ & 137 \\
\hline 15 & & $1722-1733$ & \\
\hline 16 & & $1733-1753$ & \\
\hline 17 & & $1740-1742$ & \\
\hline 18 & & $1742-1743$ & \\
\hline 19 & & $1743-1746$ & \\
\hline 20 & & $1746-1747$ & \\
\hline
\end{tabular}


Enquanto que nas Atas temos o registro das sessões da Câmara e, consequentemente, a frequência de reuniões, no Registro Geral temos uma situação distinta. Nesse, temos o registro da documentação diversa da vida municipal de São Paulo. Dessa forma, uma análise quantitativa não nos fornece dados relevantes, visto que a documentação avulsa registrada varia muito, não podendo ser observado um padrão de frequência.

\section{Cartas de Datas de Terra}

As Cartas de Datas de Terra correspondem à publicação de todo assunto referente à questão da terra dentro do termo do município, independente de ser a terra urbana ou rural. Foram organizados, para o período de 1560 a 1765, quatro volumes, publicados pela Secretaria Municipal da Cultura da Prefeitura de São Paulo.

O esforço da publicação das Cartas de Datas difere do empregado nas edições das Atas e do Registro Geral. São, na verdade, uma compilação de documentos que "misturavam-se com os mais variados assuntos, pelo que eram dificilmente compulsadas" 283 .

Dessa forma, não há documentação manuscrita ou microfilmada sobre as datas de terra no Arquivo Histórico Municipal. O que pudemos verificar, cruzando as Cartas de Datas de Terra, com as Atas da Câmara e o Registro Geral, é que toda a documentação transcrita sobre terras foi organizada e publicada.

Na publicação das Cartas de Datas de Terra, obstante o título, não encontramos somente cartas de concessão de propriedades fundiárias. Encontramos também documentação sobre 
demarcação do termo e rossio do município, discussões sobre limites da vila de São Paulo com a vila de Parnaíba e as discussões sobre as terras dos índios.

A documentação selecionada foi organizada cronologicamente, mantendo-se, no final do documento, a referência de origem, seja das Atas quanto do Registro Geral. Contém também índice toponímico e onomástico, o que facilita a consulta.

De maneira geral, as Cartas de Datas de Terra são registros de concessões de propriedades da Câmara a moradores do município. Nela consta o nome do requerente, a justificativa para o pedido, a localização aproximada da propriedade e a dimensão em braças.

\section{Nobiliarquia Paulistana de Pedro Taques}

A Nobiliarquia paulistana, de Pedro Taques de Almeida Paes Leme, pode ser considerada o primeiro esforço em escrever uma memória das famílias na América Portuguesa e foi escrita entre os anos de 1742 e 1777, data da morte do autor, conforme nos indica Azevedo Marques ${ }^{284}$.

Afonso d'Escragnolle Taunay, no Prefácio da edição de 1953 da Nobiliarquia, relata que

dispersaram-se os seus volumes manuscritos: da enorme Nobiliarquia, dos seus cem títulos salvou-se um terço, graças ao fato de existirem cópias em Portugal e graças aos cuidados de João Pereira Ramos de Azeredo Coutinho, do conselheiro Diogo de Toledo Lara e Ordonhes e afinal do visconde de S. Leopoldo, cujo filho ofereceu ao Instituto Histórico e Geográfico Brasileiro o manuscrito do genealogista $^{285}$.

Em obra de 1923, intitulada Pedro Taques e o seu tempo, Taunay relata a vida do autor, dedicando os últimos capítulos à narrativa das publicações da Nobiliarquia. De acordo com Taunay,

284 Manuel Eufrásio de Azevedo Marques. Apontamentos históricos, geográficos, biológicos, estatísticos e noticiosos da província de São Paulo. São Paulo: Martins, 1954, vol. II, p. 253.

285 Afonso de E. Taunay. Prefácio. In PAES LEME, Pedro Taques de Almeida. Nobiliarquia paulistana. São Paulo:

Comissão do IV Centenário, 1953, p. 35. 
“fez a fundação do Instituto Histórico e Geográfico de São Paulo, em 1895, com que logo se pensasse na oportunidade da reedição da Nobiliarquia Paulistana, o que não se levou a efeito, contudo" ${ }^{286}$.

Com a proximidade do bicentenário de nascimento de Pedro Taques, em 1914, o Instituto Histórico e Geográfico de São Paulo realiza homenagens ao autor setecentista. Em sessão ordinária de 20 de julho de 1914,

o dr. Escragnolle Taunay subindo á tribuna leu um substancioso trabalho sobre a vida do ilustre autor da 'Nobiliarchia Paulistana' em o qual, atravez de documentos até hoje ineditos e pelo illustrado orador pacientemente rebuscados, acompanha-o em seu doloroso peregrinar pela vida. Ao terminar o orador, que durante hora e meia teve preza a attenção do auditorio recebeu destes os mais calorosos $\operatorname{applausos}^{287}$.

Ao descrever o conteúdo da Nobiliarquia, Taunay afirma que

o estudo acurado dos troncos decorrentes dos primeiros povoadores de São Paulo, levou-o ao estabelecimento de noventa e sete títulos genealógicos, quiçá, maior número ainda, pois, nos vinte e quatro impressos, referencias se lêem a setenta e três ineditos, sendo, portanto, muito provável que na parte desconhecida da obra haja alusões a novos capítulos ${ }^{288}$.

Apresenta, ainda, complementando a descrição do "doloroso peregrinar pela vida", que, "para realizar tão formidável obra, no bárbaro Brasil setecentista, onde as comunicações eram increditavelmente difíceis, precisou o seu autor fazer um dispêndio de energia absolutamente $\operatorname{pasmoso"} 289$.

286 Afonso de E. Taunay. Pedro Taques e o seu tempo. São Paulo: Diario Official, 1923, p. 223.

$28713^{a}$. Sessão ordinária em 20 de julho de 1914. Revista do IHGSP. São Paulo, 1914, vol. 19, p. 1189.

288 Afonso de E. Taunay. op. cit., p. 226.

289 Afonso de E. Taunay. op. cit., p. 226. 
Relata Taunay que,

ainda adolescente, aos 16 anos, já cogitava do assunto capital de sua vida inteira; data de 1742 o título dos Buenos, de 1748, o dos Arrudas Botelhos e Sampaios; jamais se descurou, um só dia, da faina de avolumar materiais, o cabedal de suas notas e apontamentos, por mais longe que o levassem o desejo de enriquecer ou a defesa dos interesses familiares às solidões de Goiás e às do Mato Grosso $0^{290}$.

O período fecundo de trabalho de Pedro Taques se deu em 1763, quando de volta de Portugal, fixara a vida em São Paulo, onde exerceu o cargo de tesoureiro da Bula de Cruzada. Pôde, então, continuar sua obra e, para tanto, "mandaram-lhe então os prepostos informações e cópias de documentos, e ele próprio entreteve enorme correspondência com mil e um interrogados, realizou viagens, a feição dos iter dos antigos historiadores por toda parte onde supunha encontrar papéis velhos e documentos"291.

Conforme apontamos, não chegou até nós a Nobiliarquia completa, apenas fragmentos. Esses somente foram preservados pelo fato de "Fernandes Pinheiro, visconde de S. Leopoldo, que com ele em Lisboa se encontrara, sobremaneira se interessara também pela Nobiliarquia; chegou a copiar-lhe páginas e páginas, a pedido do patrício e amigo Diogo Ordonhes, ouvidor de Cuiabá e deputado à Assembléia Constituinte" ${ }^{292}$.

Com a morte de Ordonhes,

passaram os 59 cadernos da cópia da Nobiliarquia para o poder do irmão, o Marechal Arouche, que bem lhes aquilatava o valor. Desaparecido por sua vez este, em junho de 1834, pôs-se S. Leopoldo a campo para salvar tão precioso espólio dos perigos que o ameaçavam. Pediu encarecidamente à filha do Marechal, que por, por algum tempo, e para os mandar copiar, lhe confiasse os manuscritos ${ }^{293}$.

290 Afonso de E. Taunay. op. cit., p. 226. 
Decidiu D. Maria Benedita de Toledo Arouche doar os manuscritos ao visconde de S. Leopoldo, que teve-os em mãos durante alguns anos; por sua morte, em 1847, tocaram ao filho Dr. José Feliciano Fernandes Pinheiro, e este, “bem inspirado quanto possível, ofereceu-os ao Instituto Histórico e Geográfico Brasileiro, em 1855. No seu tomo XXXII, ano de 1869, encetou a Revista do Instituto a impressão do códice, terminada no tomo XXXV"294.

Essa primeira publicação, apesar de contribuir substancialmente para a divulgação da citada obra, não teve grande repercussão. Deve-se, principalmente, ao "modo pelo qual se levou a efeito tal publicação, prejudicando a obra. Realizada em 10 fragmentos esparsos em quatro tomos e sete fascículos, tornou-se incômodo quanto possível o manuseamento do grande trabalho de Pedro Taques" 295 .

Em 1895, “ao fundar o Instituto Histórico e Geográfico de São Paulo, empenhou-se Antônio de Toledo Piza, ardorosamente, para que a nova companhia tratasse, quanto antes, da re-impressão da Nobiliarquia, para tanto, solicitando a necessaria permissão do Instituto Brasileiro" ${ }^{296}$. Obstante a permissão ter sido concedida, o projeto não seguiu adiante e a publicação não foi realizada.

Em 1870, o Instituto Histórico e Geográfico Brasileiro publica uma edição da Nobiliarquia $^{297}$, presentes nos 4 tomos de sua Revista, em uma separata. Mas, somente em 1953 realizou-se uma publicação efetiva da obra em 3 tomos $^{298}$, com prefácio de Afonso de Taunay, por conta das Comemorações do IV Centenário de São Paulo. E, em 1980, a editora Itatiaia, em coedição com a editora da Universidade de São Paulo, promoveu a reedição da obra ${ }^{299}$ de Pedro Taques, sendo essa a edição mais atual da obra.

294 Afonso de E. Taunay. op. cit., p. 231.

295 Afonso de E. Taunay. op. cit., p. 231.

296 Afonso de E. Taunay. op. cit., p. 233-234.

297 Pedro Taques de Almeida Paes Leme. Nobiliarchia paulistana: genelogia das principaes familias de S. Paulo. s. L: s. n., 1870.

298 Pedro Taques de Almeida Paes Leme. Nobiliarquia paulistana: histórica e genealógica. São Paulo: Comissão do IV Centenário da Cidade, 1953.

299 Pedro Taques de Almeida Paes Leme. Nobiliarquia paulistana histórica e genealógica. Belo Horizonte: Itatiaia/EdUSP, 1980. 
Em relação à repercussão da obra, destacam-se as críticas elaboradas por Sílvio Romero. Em História da litteratura brazileira, de 1888, no capítulo referente aos "historiadores", aborda as obras de Pedro Taques.

Afirma Romero que "Pedro Taques de Almeida Paes Leme innaugurou entre nós as nobiliarchias e memorias de familia" ${ }^{300}$. E ressalta a sua importância para o pensamento histórico colonial ao questionar

o que era antes d'elle a historia nacional? A enumeração dos reis da metropole e dos governadores da colonia, a biographia dos missionarios, a chronica das ordens monasticas. Era uma historia exterior, decorativa e insignificante na sua pretenciosidade espectaculosa. Passava-se na rua, ao ar livre, é certo; porém mettida n'um palanque ou n'um coreto; não era no chão das praças no meio da onda $\operatorname{popular}^{301}$.

Em relação à elaboração da pesquisa, o autor enumera os principais distintivos da obra de Pedro Taques:

a vasta leitura, a erudição pratica, o conhecimento positivo dos documentos historicos. Elle não teve a mania de copiar dos antecessores, molestia commum aos historiadores brazileiros antigos e modernos. Taques manuseou os archivos e carthorios; era da familia dos benedictinos europeos ${ }^{302}$.

No entanto, Romero afirma que "Pedro Taques tinha em alta escala o sentimento provinciano; antes de tudo era paulista" 303 e que seu "espirito bairrista" ignora "a acção collectiva de outras populações do paíz. Bem myope será quem nos quatro seculos de nossa historia não descortinar o rastro deixado por bahianos, paulistas, pernambucanos, rio-grandenses do sul,

300 Silvio Romero. Historia da litteratura brazileira. Rio de Janeiro: B. L. Garnier, 1888, vol. I, p. 545.

301 Silvio Romero. op. cit., p. 546.

302 Silvio Romero. op. cit., p. 550.

303 Silvio Romero. op. cit., p. 553. 
mineiros, etc" ${ }^{304}$.

Taunay, por sua vez, minimiza essas críticas, justificando que "dominado aliás pelas idéias de casta e sentindo-se um pouco parente de todos os seus biographados, dava Pedro Taques expansão a fortissimo, visceral sentimento aristocrático de preconceitos de familia, senão de classe" ${ }^{305}$.

E, em relação às críticas referentes à idealizações sobre as origens de famílias, Taunay defende Taques alegando "quão modestas são as origens pelo linhagista attribuidas ás velhas familias paulistas"306, não demonstrando, como genealogistas mais fantasiosos, relações das famílias analisadas com reis, santos e herois.

Ao relativizar críticas de exageros cometidos por Pedro Taques, Taunay aponta para outra direção, quando justifica que

onde nos parece que Pedro Taques se deixa arrastar pelas tendencias ao exaggero é ao descrever os bens dos antigos 'potentados' paulistas. Dá-lhes situações e opulencia que não condizem com a antiga pobreza do planalto piratiningano, a penúria pelos inventarios revelada: pois S. Paulo tornou-se rico da segunda metade do seculo XIX em deante ${ }^{307}$.

\section{Genealogia Paulistana de Luís Gonzaga da Silva Leme}

A Genealogia Paulistana, de Luís Gonzaga da Silva Leme, publicada em 1903, representa o principal estudo genealógico sobre famílias de São Paulo.

Afonso de E. Taunay, em artigo Silva Leme e o povoamento do Brasil central pelos paulistas, de 1940, publicado na Revista do Instituto Histórico e Geográfico de São Paulo, aborda o trabalho do genealogista, destacando

304 Silvio Romero. op. cit., p. 553.

305 Afonso de E. Taunay. op. cit., p. 254.

306 Afonso de E. Taunay. op. cit., p. 270.

307 Afonso de E. Taunay. op. cit., p. 273. 
o penoso labor! Só quem conhece as intimidades arquivais do nosso acervo está em condições de avaliar o que deve ter custado a recomposição de tantos e tantos velhos liames genealógicos. Mal tratadíssimos, truncados, desbaratados, semidevorados pelos insetos viviam os nossos papéis de filiação e de registro civil amontoados a esmo, nos desvãos dos cartórios e dos pomposamente chamados “arquivos" $"$.

Em comparação à obra de Pedro Taques, que teve três quatros perdidos, Taunay conclui que “com infatigável persistência e singular argúcia conseguiu Silva Leme recompor as linhagens referentes a numerosos capítulos da Genealogia Paulistana" ${ }^{309}$. E, dessa forma, a sua obra, "além de toda a reverência pela probidade dos informes, merece caloroso aplauso graças à valia documental que representa" ${ }^{\prime 310}$.

Sobre o esforço de reconstituição das famílias paulistas, Taunay nos relata que "a única satisfação que à singeleza modéstia permitiu foi assinalar aos seus leitores as descobertas que das filiações fizera contentando-se em pospor as simples letras q.d (que descobrimos)"311.

Luís Gonzaga da Silva Leme,

nascido a 3 de agosto de 1852, em Bragança, fez os estudos de humanidades no Seminário Episcopal de São Paulo, matriculando-se na Faculdade de Direito paulista, em 1872. Aí se bacharelou em 1876. Mas pouco pendor sentia pelas letras jurídicas. Assim resolveu estudar engenharia e se foi para os Estados Unidos a cursar as aulas do Instituto Politécnico de Troy, no estado de Nova York. Aí, em junho de 1880 , recebeu o grau de engenheiro civil ${ }^{312}$.

Retornando ao Brasil, torna-se membro do Instituto Histórico e Geográfico de São Paulo,

308 Afonso de E. Taunay. Silva Leme e o povoamento do Brasil central pelos paulistas. Revista do Instituto Histórico e Geográfico de São Paulo. São Paulo, v. 38, 1940, p. 145.

309 Afonso de E. Taunay. op. cit., p. 146.

310 Afonso de E. Taunay. op. cit., p. 146.

311 Afonso de E. Taunay. op. cit., p. 146.

312 Afonso de E. Taunay. op. cit., p. 150. 
segundo Ata da 15 a Sessão Ordinária em 20 de outubro de $1899^{313}$. Desde então "empregara todos os lazeres em acumular material para a sua futura Genealogia Paulistana. De 1891 em diante, pôde, notavelmente, aumentar o seu acervo documental. Homem de larga fortuna, conseguiu afinal, de 1898 em diante, entregar-se de corpo e alma à confecção de sua obra. Começou a imprimi-la em $1905^{\prime 314}$.

Taunay, ao relatar suas experiências com Silva Leme, aponta que "depois de publicada a sua Genealogia Paulistana, prosseguiu os seus estudos promovendo a extensão de seus capítulos, por meio de suplementos" 315 .

Após o artigo de Afonso Taunay em que descreve a vida de Silva Leme, partimos para a análise da obra e, para tanto, utilizamos a Introdução da Genealogia Paulistana.

$\mathrm{Na}$ introdução, nomeada de "Ao leitor", ele expõe ao público seus objetivos, a descrição do plano geral da obra e os agradecimentos aos que nela colaboraram.

Logo a princípio, aponta que o presente trabalho

não foi elle inspirado na vaidade de ostentar os brazões de armas que provam a nobreza de nossos antepassados, e sim na necessidade que temos de guardar as tradições de familia e satisfazer a curiosidade justificada, que nos leva a perguntar de onde viemos á que nacionalidades embora remotamente nos filiamos pelos laços de sangue, e quaes os feitos que ennobreceram aos nossos antepassados, gravando seus nomes na historia de nossa pátria ${ }^{316}$.

E compara a sua obra com a anterior do gênero, a Nobiliarquia Paulistana, de Pedro Taques. Para tanto, afirma que "n'este trabalho não nos limitamos a descrever somente as familias que teem sua nobreza firmada em brazões; mas incluirmos, como fez Pedro Taques, muitas outras que, oriundas de troncos humildes, meros povoadores, se tornaram nobres pelos seus feitos e cooperação 313 Cf. Acta da $15^{\text {a }}$. Sessão Ordinária em 20 de outubro de 1899. Revista do Instituto Histórico e Geográfico de São Paulo. São Paulo, v. 4, 1898-1899, p. 539.

314 Afonso de E. Taunay. op. cit., p. 150-151.

315 Afonso de E. Taunay. op. cit., p. 151.

316 Luís Gonzaga da Silva Leme. Ao leitor. Genealogia Paulistana. São Paulo: Duprat \& Comp., 1903, p. III. 
no engrandecimento de nossa terra" ${ }^{317}$.

Retomando a comparação de sua obra com a do autor setecentista, Silva Leme escreve que

examinando os documentos dos archivos, tivemos occasião de verificar que Pedro Taques foi consciencioso na confecção de sua Nobiliarchia Paulistana; alguns erros e discrepancias que encontramos em sua obra, são effeitos de informações errôneas por elle colhidas, na impossibilidade de consultar pessoalmente alguns desses archivos: estes mesmos erros provavelmente encontrareis n'este trabalho ${ }^{318}$.

Por fim, apresenta que "escrevemos, além da introducção, 52 títulos de familias diversas que vieram na maior parte nos principios da povoação de S. Vicente e S. Paulo, e poucas no fim do século $16^{\circ}$ e principio do $17^{\circ}$, as quaes vão distribuidas em 8 volumes de 550 paginas cada um" 319 .

Dessa forma, apresenta o objetivo central de sua obra, ao afirmar que

tivemos em mira despertar os brios das gerações de hoje para que continuem seguindo a senda trilhada pelos seus antepassados, na practica d'esses actos de heroismo e de abnegação pela causa publica, e assim consigam legar a seus filhos um nome glorioso; e, para que esta nobreza perpetue- $\mathrm{se}^{320}$.

Ao sugerir aos leitores que "colloquem diante d'elles [seus filhos] os vultos venerandos de seus avós para que sirvam de modelos a serem imitados [e assim] firmarão a nobreza de suas familias"321, o autor nos revela o esforço em perpetuar a preponderância das famílias paulistas.

Tal sentimento se dá, segundo Raquel Glezer, pois, no início do século XX,

o estado de São Paulo passou a ser considerado o herdeiro dos elementos qualificados do bandeirismo: espírito de iniciativa, valentia e arrojo. Da mesma

317 Luís Gonzaga da Silva Leme. op. cit., p. III.

318 Luís Gonzaga da Silva Leme. op. cit., p. IV.

319 Luís Gonzaga da Silva Leme. op. cit., p. IV.

320 Luís Gonzaga da Silva Leme. op. cit., p. III.

321 Luís Gonzaga da Silva Leme. op. cit., p. IV. 
maneira que o bandeirante desbravara os sertões brasileiros, conquistando-os para Portugal e criando o Brasil geograficamente, o paulista, isto é, o estado de São Paulo, melhor dizendo, a oligarquia paulista, construía o progresso do Brasiß22.

E, dentro desse contexto, o esforço de Silva Leme em construir uma memória das famílias tradicionais permite, pois, a conexão entre o paulista do passado, através da figura idealizada do bandeirante construída pela historiografia do início do século $\mathrm{XX}$, com o paulista do presente, legitimando suas ações e justificando seu papel de destaque na política nacional.

\section{2 - Banco de Dados}

\section{Metodologia}

A elaboração de um Banco de Dados exige que pensemos sobre quais métodos devemos utilizar nessa tarefa. $\mathrm{O}$ trabalho quantitativo com fontes qualitativas, exigem, necessariamente, que façamos escolhas. Em relação à essa abordagem, Pierre Chaunu afirma que

a História esforça-se por dar a conhecer o passado. Mas que escolha exerce na duração à medida que a massa de documentos legados pelo passado cresce e que é preciso, forçosamente, escolher? As escolhas mais perigosas são as escolhas implícitas. A grande aquisição da História, no decorrer dos últimos oitenta anos, situa-se ao nível de uma escolha cada vez mais consciente. Ao nível, portanto, daquilo a que se chama a problemática ${ }^{323}$.

Dessa forma, o trabalho estatístico com fontes descritivas e não numéricas, nos leva a fazer escolhas. Devemos converter as informações contidas em documentos textuais para variáveis que 
possam ser contabilizadas e, consequentemente, ponderadas suas ocorrências. Em tais ações, somos obrigados e abdicar algumas informações qualitativas para que possamos quantificar padrões de ocorrência. Tais perdas, inevitáveis, são necessárias para que possamos analisar um fenômeno social em seu aspecto mais amplo.

\section{Panorama da História quantitativa}

Para poder problematizar a história quantitativa, devemos retomar às origens da História Econômica. Segundo Pierre Chaunu, a economia política surgida na Inglaterra, no último quartel do século XVIII e das primeiras décadas do XIX, decorre da Revolução Industrial e de suas consequências ${ }^{324}$.

A Ciência Econômica é, segundo Chaunu, "a primeira constituída com o aparelho matemático, sem a qual já não há, desde (...) o século XVII, qualquer conhecimento científico" ${ }^{325}$.

Na década de 1890, há o aparecimento tímido de capítulos de história econômica nas histórias nacionais. Essa preocupação decorre da disputa econômica e imperialista durante o período, apesar de, como afirma Chaunu, "esse capítulo [de história econômica] ter sido lançado no final e que quatro quintos do discurso foram consagrados ao Estado" ${ }^{\$ 26}$.

Com a crise de 1929, a História Econômica se destaca, por assumir papel de "uma tentativa de resposta, sem dissimulações, aos angustiantes problemas de uma época"327. Tal situação reflete na intensa produção sobre crise mundial, "uma bibliografia enorme, várias dezenas de livros em quarenta anos" ${ }^{\prime 328}$, conclui Chaunu.

A afirmação de que a história econômica moderna nasceu na década de 30 do século XX é reforçada com a criação, em 1929, por Marc Bloch e Lucien Febvre, da Revista dos Annales, com 
um título revelador, Annales d'histoire économique et sociale ${ }^{329}$.

A História Econômica, entre 1945 e 1960, esforçou-se em incorporar, sob o impulso de Ernest Labrousse e Fernand Braudel, a Geo-História ${ }^{330}$. Utiliza-se, portanto, uma nova temporalidade, marcada por longos intervalos de tempo.

Para as décadas de 1950 e 1970, há um predomínio de trabalhos estabelecidos por economistas. Essa forma de História quantitativa é, segundo Chaunu, a história do crescimento econômico $^{331}$. Tem destaque as produções da New Economic History e o predomínio de estudos históricos econômicos, que, no seu limite, chegou a estudos de Econometria, deixando de ser História para torna-se predominantemente Economia. De acordo com Chaunu, a principal limitação dessa corrente deve-se ao fato "da Nova História Econômica quantitativa sair mais dificilmente do que a dinâmica conjuntural e a História geográfica dos anos 30 e 50 do setor econômico estreitamente delimitado" ${ }^{332}$.

François Furet, em relação à New Economic History, afirma que "la vraie histoire quantitative résullerait ainsi, dans la logique de cette conception, d'une double réduction de l'histoire: réduction, au moins provisoire, de son champ à l'économie, et réduction du système descriptif et interprétatif à celui qui a été élabore par la science sociale la plus rigoureusement constituée d'aujord'hui: l'économie politique"333.

A partir da década de 1960, com a história serial, a História quantitativa pretendeu "alcançar, na sua totalidade, uma estrutura de civilização"334. Para tanto, estabeleceu diálogo com a Sociologia, Antropologia e Psicologia e abordou temáticas culturais, políticas e psicológicas.

No entanto, essa aproximação ocorreu com um certo atraso. A década de 1960, marcada por

329 Para um contexto sobre os Annales, ver Peter Burke. A Escola dos Annales (1929-1989): a revolução francesa da historiografia. São Paulo: EdUNESP, 1997.

330 Para a discussão sobre a expressão, ver Pierre Chaunu. L'histoire geographique. Revue de l'anseignement supérieu. 1960, n. 44-45, pp. 66-77.

331 Pierre Chaunu. op. cit., p. 80.

332 Pierre Chaunu. op. cit., p. 91.

333 François Furet. L'histoire quantitative et la construction du fait historique. Annales. Économies, Sociétés, Civilisations, 1971, vol. 26, n. 1, p. 64.

334 Pierre Chaunu. op. cit., p. 98. 
crises e mudanças comportamentais, exigia uma mudança no campo de estudo da História.

Entre os slogans escritos nas paredes da Sorbonne, em 1968, destaca-se a frase "On ne tombe pas amoureux d'um taux de croissance"335. A partir dessa crise, notamos uma dedicação maior da História quantitativa com temáticas sociais. Estudos sobre a vida, o amor, morte, palavras e gestos, se destacam no período. Pierre Chaunu conclui que, dessa forma,

a História regressa ao psicológico, mas ao psicológico social, ela associa-se livremente a todas as ciências do homem, sem se deixar absorver; ela utiliza os meios que a Estatística, a Eletrônica e as máquinas lhe oferecem, sem renunciar ao espírito de finesse, sem renunciar ao estudo do belo texto, do grande texto. ${ }^{336}$

Bernard Lepetit, em artigo publicado em 1989, apresenta um contexto diverso do apresentado por Chaunu e Furet. No final da década de 1980, “l'histoire quantitative n'est plus à la mode" 337 .

Essa mudança, ocorrida no espaço de uma geração, foi marcada pela preponderância de temáticas sociais e pelo abandono das fontes e métodos quantitativos. Segundo Lepetit, "l'histoiren ne se contente pas de définir ses problèmes, il contruit ses objets, choisit sa démarche, sélectionne et élabore ses indicateurs - le paradigme de l'indice vaut aussi por l'histoire quantitative -, invente les sources que son questionnement suppose" ${ }^{338}$.

Conclui seu panorama atual da história quantitativa afirmando que "l'usage des modèles quantitatifs suggère que la pertinence du discours peut s'apprécier à plusieur niveaux" ${ }^{\prime 33}$ e que "mais il semble déjà qu'un usage plus delié des outils quantitatifs éviterait à l'histoire d'avoir à

335 Para um contexto do movimento estudantil de 1968 na França, ver Olgária Mattos. Revolução estudantil dos anos 60. In NAKANO, Y., REGO, J. e FURQUIM, L. (org.). Em busca do novo. O Brasil e o desenvolvimento na obra de Bresser-Pereira. Rio de Janeiro: EdFGV, 2004, pp. 297-311.

336 Pierre Chaunu. op. cit., p. 101-102.

337 Bernard Lepetit. L'histoire quantitative: deux ou trois choses que je sais d'elle. Histoire \& mesure, 1989, vol. 4, n. 3, p. 191.

338 Bernard Lepetit. op. cit., p. 195.

339 Bernard Lepetit. op. cit., p. 198. 
choisir entre le positivisme et al rhetorique" ${ }^{\$ 40}$.

\section{Fontes qualitativas usadas de forma quantitativa}

As mudanças ocorridas a partir da década de 1960 alteraram a abordagem da história quantitativa. A história econômica, segundo Pierre Chaunu, à época, "menos do que um objeto, é principalmente um estado de espírito, um conjunto de métodos, uma abordagem" ${ }^{341}$. Requer, dessa forma, uma problematização permanente das fontes e métodos utilizados pelos historiadores.

A princípio, François Furet aponta uma importante questão sobre a utilização de fontes de forma quantitativa. Afirma que "l'histoire sérielle, à coup sûr, apporte des procédures précises pour mesurer le changement, mais dans quelle mesure permet-elle de penser les mutations??342.

Continua ponderando que

la mutation historique décisive peut n'être inscrite dans ancune série endogène à un système donné, mais résulter soit d'une innovation dont aucune comptabilité antérieure n'a laissé de trace, soit d'un facteur exogène qui vient bouleverser l'équilibre pluri-séculaire du système. ${ }^{343}$

Dessa forma, "dans la mesure où l'histoire quantitative suppose l'existence et l'elaboration de longues séries de donnés homogènes et comparables, le premièr problème qui se pose en termes nouveaux est celui des sources ${ }^{{ }^{344}}$.

A ideia de preservação e estabilidade, muitas vezes alegadas à história quantitativa é questionada por Furet. Para o autor, essa é uma leitura superficial das fontes históricas, que ignora suas possibilidades implícitas. Afirma ainda que, 
les donnés de l'histoire quantitative ne renvoient pas à un insaisissable découpage externe du 'fait', mais à des critères de cohérence interne: le fait n'est plus l'événement sélectioné parce qu'il scande les temps foits d'une histoire dont le 'sens' a été préalablement défini, mais un phénomène choisi et éventuellement construit en fonction de son caractère répétitif, donc comparable à travers une unité-temps ${ }^{345}$.

Portanto, "se précise la première tâche de l'histoire sérielle, l’impératif de son développment: c'est la constituiton du matériau d'analyse" ${ }^{346}$. A utilização crítica dessas fontes torna-se imprecindível, o que possibilita que "dans sources déjà exploitées dans le passé peuvent être réutilisées à d'autres fins, si elles sont investies par le chercheur d'une signification nouvelle" 347 .

A utilização de métodos quantitativos permite, dessa forma, uma importante renovação historiográfica. Temas já explorados pela historiografia podem ser novamente utilizados, com problemáticas e métodos distintos, contribuindo com novas perspectivas de pesquisa.

No entanto, essas novas abordagens quantitativas requerem cuidado. Furet defende que "le meniement de sources sérielles oblige donc l'historiens à réfléchir soigneusement à l'incidence que peuvent avoir les conditions d'organisation de ces sources sur leur utilisation quantitative" ${ }^{348}$.

Para a pesquisa dessa dissertação, utilizaremos fontes qualitativas, no caso documentação administrativa e registros de cartas de datas de terra, de forma quantitativa. Para essa abordagem,

il faut qu'il en détermine une signification univoque, par rapport à la question qu'il pose; mais aussi qu'il puisse les réorganiser en séries, c'est-à-dire en unités chronologiques comparables, au prix d'un travail de standardisation évidemment 
plus complex encore que dans le cas précédent. ${ }^{349}$

Por isso, "l'historien d'ajourd'hui se trouve obligé à renonver à la naïveté méthodologique et à réfléchir aux conditions d'établissement de son savoir" ${ }^{350}$. Conclui Furet que "l'histoire sérielle décrit au contraire des continuités sur le mode du discontinu: c'est une histoire-problème(s), au lieu d'être une histoire-récit”,351.

\section{Problemáticas para o Banco de Dados}

Com o objetivo de compreender as relações entre poder local e a concessão de terra urbana no município de São Paulo colonial, estabelecemos, a princípio, seis eixos de problemas que estruturam o Banco de Dados.

Dessa forma, o Banco de Dados deve responder à principal questão da presente dissertação, que é compreender as relações entre poder local e concessão de terras. Isto é, devemos, através do cruzamento entre a listagem de membros do poder municipal com a de requerentes de terras, verificar se há relação direta ou não.

A segunda problemática é compreender as relações familiares nas concessões de terra. Para tanto, verificar-se-á qual o vínculo familiar do requerente com o membro do poder local, quando houver e se é possível verificar padrões de ocorrência em esses casos. Também é objetivo ponderar as relações de gênero nas concessões, quantificando os requerentes masculinos e femininos, assinalando períodos de maior ocorrência de casos.

A terceira problemática se refere à busca por padrões de argumentações nas solicitações de terra. Essa questão é fundamental para qualificar melhor as características das datas, visto que 
Taunay $^{352}$, ao afirmar que a terra urbana destina-se a quem precisa e, portanto, aos mais desprovidos, utiliza-se justamente das argumentações colhidas nas Cartas de Datas de terra.

A quarta problemática se refere à importância da função do escrivão. Conforme apresentamos anteriormente no capítulo 1.3, não havia exigência para que os membros da administração local fossem letrados, exceto o escrivão. Com isso, temos esse como o único representante da cultura letrada na administração do município, principalmente nas primeiras décadas da colonização. A questão é a qual ponto a escrita pode ser considerada como um fator de distinção social e, consequentemente, motivo para solicitação de terras urbanas.

A quinta problemática, em parte consequência da primeira, diz respeito à relação entre concessões de terra e ocupação de cargos honorários na câmara municipal. Conforme Hespanha ${ }^{353}$ apontou, os cargos de juiz ordinário, vereador e procurador do concelho, ao contrário dos demais, não eram remunerados, sendo honorários. Propomos verificar até que ponto as terras do concelho foram utilizadas como forma de retribuição por serviços prestados à municipalidade.

A sexta problemática refere-se à busca por padrões na ocupação geográfica do município com as datas de terra. Propomos verificar quais áreas estão sendo ocupadas em certos períodos e buscar eixos de urbanização, através da descrição de localização das terras doadas presentes nas Cartas de Datas de Terra.

A sétima e última problemática diz respeito à dimensão das propriedades doadas pela câmara. Procuramos, nesse momento, verificar em quais áreas foram concedidas maiores extensões de terra e se o rossio foi, conforme a historiografia aponta ${ }^{354}$, destinado à pequenas propriedades. Consequentemente, visamos incluir nesse questionamento a relação entre a dimensão da propriedade e o vínculo com cargos da câmara do requerente e, em especial, a relação entre extensão de terra e cargos honorários.

352 Afonso de E. Taunay. São Paulo nos primeiros anos e São Paulo no século XVI. São Paulo: Paz e Terra, 2003, p. 106.

353 Antonio M. Hespanha. As vésperas do Leviathan. Coimbra: Almedina, 1994, p. 164.

354 Ver Afonso de Taunay. São Paulo nos século XVI e São Paulo nos primeiros anos. São Paulo: Paz e Terra, 2003 e Raquel Glezer. Chão de terra e outros ensaios sobre São Paulo. São Paulo: Alameda, 2007. 
No entanto, antes de iniciarmos a proposta de Banco de Dados, devemos apontar alguns problemas e limitações das questões acima propostas. Tal postura foi fundamental para que pudéssemos construir um Banco de Dados mais claro e objetivo, bem como poupar tempo com questões que não nos levaria a conclusões relevantes.

A princípio, devemos considerar, conforme apresentado, que a documentação sobre administração municipal de São Paulo, apesar de extensa, contém inúmeras falhas, bem como as Cartas de Data de Terra. Dessa forma, não podemos considerar as informações levantadas como absolutamente fidedignas e sim como indicativas de padrões de ocorrência. Adiante, iremos problematizar melhor a questão das séries documentais, bem como a opção por uma duração mais longa, a fim de minimizar as falhas nos documentos.

A segunda ponderação refere-se à característica da documentação consultada. Tanto as Atas da Câmara quanto as Cartas de Datas de Terra são documentos oficiais, e que, portanto, contemplam as ocupações legais de terra. Não temos, dessa forma, registros de ocupações de terra fora dos registros municipais. Sabemos, que há, no século XVII, inúmeras solicitações de legalização de ocupações em terras indígenas, principalmente na aldeia de São Miguel, alegando que a proprietária a ocupara há muito tempo e que tinha a posse de fato. Tal situação de populações dispersas e sem uma regulamentação oficial é frequente na colonização da capitania de São Vicente e depois da de São Paulo, a ponto de, a partir de 1765, o morgado de Mateus iniciar uma política de povoamento da capitania reunindo a população dispersa e organizando municípios ${ }^{355}$.

A terceira ponderação, em parte consequência da segunda, refere-se à limitação de verificar padrões de áreas de ocupação, tal como havíamos proposto na sexta problemática. Verificar somente as ocupações registradas não nos permite traçar um panorama convincente das áreas de urbanização, visto que não temos como quantificar e ponderar as ocupações não oficiais.

Além disso, nem todas os registros de datas de terra contêm informações referentes à 
localização das mesmas. E, nas que há, as descrições são muito limitadas e, vezes citam descrições muito específicas e baseadas em elementos não fixos, tais como muros, árvores e propriedades de pessoas conhecidas na época.

Dessa forma, avaliando os problemas das questões anteriormente levantas, optamos por desconsiderar a sexta problemática, devido à impossibilidade de verificar informações relevantes sobre a questão.

\section{Construção do Banco de Dados}

Antes de apresentarmos o Banco de Dados propriamente dito, devemos nos deter nas duas listagens confeccionadas com o intuito de abastecer o mesmo. A primeira listagem foi elaborada a partir da Lista de Composição do Poder Municipal em São Paulo (1560-1765), presente no Anexo A, em que relacionamos, a cada ano, os ocupantes dos cargos de juiz ordinário, vereadores, procurador, escrivão, almotacel, alcaide, capitão-mor e capitão dos índios.

Foi também elaborada a listagem das Cartas de Datas de Terra (1560-1765), presente no Anexo B, em que organizamos as solicitações de terras de acordo com as problemáticas apresentadas. Para tanto, definimos as seguintes categorias a serem observadas na documentação: data da carta, nome do requerente, argumentação da solicitação, localização da propriedade, dimensão da mesma em braças quadradas e observação, em que é definido se haverá pagamento de foro e qual será o valor do tributo.

Com essas duas listagens, elaboramos a Tabela de Resultados obtida através do cruzamento das Cartas de Datas de Terra com a Composição do Poder Municipal em São Paulo. Nessa tabela, presente no Anexo C, assinalamos os nomes dos requerentes das concessões e seu vínculo com a administração local, bem como a data em que ocuparam tais cargos.

Para os nomes que não encontramos vínculo direto buscamos vínculos familiares dos 
requerentes com os membros da Câmara. Para tanto, utilizamos as principais obras genealógicas para a cidade de São Paulo, a Nobiliarquia paulistana, de Pedro Taques e a Genealogia paulistana, de Silva Leme. Devido a complexidade das relações familiares de São Paulo colonial, não buscamos traçar relações familiares amplas e sim relações simples de primeiro grau, como filhos, pais, primos, genros, sobrinhos e cônjuges.

Definida a Tabela de Cruzamento acima apresentada, podemos apresentar o Banco de Dados (Anexo D), objetivo central dessa dissertação. Conforme Furet e Chaunu apontaram acima, o uso da informática permite que a sistematização de dados e seu tratamento estatístico ocorra de forma mais rápida e eficiente. Para tanto, para a construção de nosso Banco de Dados utilizamos o aplicativo Statistical Package for the Social Sciences (SPSS).

Para a elaboração do Banco de Dados pautamo-nos nas problemáticas anteriormente apresentadas com o intuito de guiar-nos nessa etapa. Definimos, portanto, quinze variáveis, as quais apresentamos abaixo.

A primeira variável corresponde ao ano da concessão da terra. Optamos por registrar apenas o ano e não os dias e meses por trata-se de um período amplo a ser analisado. E, dessa forma, podemos, apenas com o ano, verificar uma distribuição das concessões de terra no período de 205 anos a ser contemplado pela presente pesquisa.

A segunda variável diz respeito ao nome do requerente da terra. Tal dado é fundamental para que possamos cruzar os nomes dos solicitantes com o dos membros da administração local.

A terceira variável corresponde ao gênero do solicitante, se esse é do grupo masculino ou feminino.

Na quarta variável é apresentado o vínculo do requerente com o poder local. Para tanto, utilizamos os valores Sim, vínculo direito, Sim, vínculo indireto e Não, aparentemente. Esse último foi apresentado dessa forma, visto que não podemos afirmar categoricamente que não há vínculo algum com o poder local. Pode ocorrer nessa negação uma falha de documentação, o que torna o 
valor negativo como algo não muito confiável.

A quinta variável corresponde ao período de concessão da terra. Se essa ocorreu antes do vínculo, depois do vínculo ou antes e depois do vínculo. Tal variável nos permite melhor qualificar a relação entre concessões de terra e ocupação de cargos municipais, pois possibilita ver se a concepção de retribuição por serviços prestados à municipalidade foi aplicada nesses casos.

A sexta variável diz respeito ao cargo que o requerente ocupou na administração municipal. Utilizamos categorias, a fim de facilitar a análise, dentre as quais: governo (procurador, vereador e escrivão), justiça (juiz ordinário), defesa (alcaide) e nenhum. As seguintes categorias, concebidas com finalidades operacionais, podem ser combinadas entre si, como no caso do requerente ter ocupado diferentes cargos na administração local.

$\mathrm{Na}$ sétima variável ponderamos a importância do representante da cultura letrada na administração local colonial. Para tanto, assinalamos se o requerente assumiu, em algum momento, o cargo de escrivão da Câmara.

A oitava variável diz respeito se o requerente que ocupou cargos na Câmara pertencia à categoria dos cargos honorários, ou seja, que não recebiam remuneração pelas tarefas elaboradas. Essa variável é de extrema importância para responder à quinta problemática.

A nona variável refere-se à localização da propriedade doada. Conforme apontamos acima, a problemática referente à distribuição espacial das concessões foi parcialmente abandonada, mas optamos por manter essa variável pois a mesma nos permite definir quais terras foram concedidas em terras de índios ou fora do termo do município.

$\mathrm{Na}$ décima variável é registrada a dimensão da propriedade concedida medida em braças quadradas. Quando não temos o dado referente, definimos a ausência não como zero, pois esse valor não é uma ausência e sim com o missing value (999), que corresponde a valor perdido.

Para a décima primeira variável, que corresponde à análise das dimensões das propriedades concedidas, definimos algumas categorias. Dessa forma, pudemos verificar as relações entre terra e 
poder político em um sentido mais amplo, buscando categorias políticas privilegiadas no processo de concessão de terra urbana.

Para essa finalidade, definimos quatro categorias referentes à dimensão das propriedades, baseadas em braças quadradas: a primeira, entre 1 e 25 braças, correspondendo à pequenas propriedades; a segunda, entre 26 e 100 braças, correspondendo às médias propriedades; a terceira, entre 101 e 500 braças, correspondendo às grandes propriedades e, por fim, a última, para terras com mais de 501 braças, para propriedades muito grande, se pensarmos em relação à maioria das terras doadas.

A décima segunda variável corresponde à relação de parentesco do requerente com o membro do poder local. Tal situação ocorre quando o vínculo com o poder local é indireto. Nos demais casos, utilizamos o missing value, pois indica que a situação é inexistente.

Na décima terceira variável são definidos os padrões de argumentações para solicitação de terra. Optamos por agrupar as motivações em grandes categorias para que possamos verificar padrões de ocorrência. Definimos, para tanto, os seguintes padrões: recompensa, necessidade, regularização, casamento com órfã, guerra, morador antigo, casamento com "nobreza da terra, serviço de S. Magestade, serviço de Deus, licença para moinho, licença para minas, costume, aumento da cidade, correição do ouvidor geral, ocupar terras devolutas e serviço do povo.

A décima quarta variável corresponde ao valor do tributo pago à câmara pela concessão de terra. O foro, pode ser anual, pago somente no ato do aforamento, ou não cobrado, tornado a data isenta. Ponderamos o valor em réis e para as ausências de dados, utilizamos 999 como missing value.

$\mathrm{Na}$ décima quinta variável, calculamos o valor pago do tributo por braça quadrada. Cálculo esse que permite, mesmo que de maneira geral, verificar o preço médio dos tributos pagos pelas propriedades doadas ao longo do período analisado.

A décima sexta e última variável corresponde às observações, que têm intuito mais de 
apontar informações qualitativas importantes constantes na requisição de terras do que permitir uma análise quantitativa de seus elementos.

\section{3 - Resultados Obtidos}

\section{Introdução}

Nessa parte do capítulo, iremos apresentar os resultados obtidos a partir do Banco de Dados proposto. Pretendemos, com as análises quantitativas e o cruzamento de fontes, responder às problemáticas levantadas no capítulo 2.2 .

A partir dos gráficos e tabelas desenvolvidos, propomos uma discussão que possa colaborar na compreensão sobre a relação entre poder político local e a distribuição de terras urbanas no termo do município de S. Paulo

\section{$1^{\mathrm{a}}$ Problemática}

A primeira problemática traçada diz respeito à questão-chave dessa pesquisa. Trata-se da relação entre poder municipal e concessão de terras pela Câmara.

\begin{tabular}{l|l|l}
\hline \multicolumn{3}{c}{ Tabela 4 - Vínculo com a Câmara Municipal } \\
\hline & Frequência & Porcentagem \\
\hline Sim, Direito & 125 & $51,44 \%$ \\
Sim, Indireto & 41 & $16,87 \%$ \\
Não, Aparente & 77 & $31,69 \%$ \\
\hline Total & 243 & $100,0 \%$ \\
\hline
\end{tabular}

Verificamos que $51,44 \%$ das concessões registradas nas Cartas de Datas de Terra correspondem a requerentes que possuíam vínculo direito com a Câmara Municipal. Dessa forma, 
pouco mais da metade das terras foram concedidas a quem ocupou cargos políticos na edilidade.

Apesar de representar mais da metade das concessões, tais dados não nos permitem definir um contexto mais amplo. Devemos notar que $16,87 \%$ das datas foram concedidas a uma categoria, definida por nós, como vínculo indireto. Esses são os parentes de membros da administração municipal, categoria que iremos desenvolver melhor adiante.

Dessa forma, obtemos $68,31 \%$ das concessões como relacionadas, seja direta ou indiretamente, com o poder político local. Vale ressaltar, contudo, que os $31,69 \%$ dos casos que foram marcados como sem vínculo, definido por nós como vínculo aparentemente negativo, visto que são as ocorrências nas quais não encontramos relação de parentesco aparentes, o que não quer dizer que não são necessariamente os casos em que não há vínculo.

Com esse panorama, podemos afirmar que a proposta inicialmente levantada, de que a concessão de terras se deu, principalmente, a membros do poder municipal, pode ser considerada válida. Cabe, agora, caracterizar melhor essa relação, que será explicitada nas problemáticas seguintes.

\section{$2^{\text {a }}$ Problemática}

Conforme apresentamos no item anterior, $16,87 \%$ das terras foram concedidas a parentes dos membros da administração municipal. Cabe analisar quais eram esses vínculos familiares e quais as consequências dessas relações na compreensão do poder local em São Paulo colonial.

Tabela 5 - Relações de Parentesco com oficiais da Câmara

\begin{tabular}{l|l|l|l}
\hline & Frequência & Porcentagem & Porcentagem Válida \\
\hline Genro & 10 & $4,1 \%$ & $24,4 \%$ \\
Sogro & 3 & $1,2 \%$ & $7,3 \%$ \\
Esposa & 3 & $1,2 \%$ & $7,3 \%$ \\
Cunhado & 2 & $0,8 \%$ & $4,9 \%$ \\
\hline
\end{tabular}




\begin{tabular}{l|l|l|l}
\hline Casou com viuva & 2 & $0,8 \%$ & $4,9 \%$ \\
Filha do genro & 1 & $0,4 \%$ & $2,4 \%$ \\
Genro e Irmão & 1 & $0,4 \%$ & $2,4 \%$ \\
Filho & 11 & $4,5 \%$ & $26,8 \%$ \\
Irmão & 6 & $2,5 \%$ & $14,6 \%$ \\
Pai & 1 & $0,4 \%$ & $2,4 \%$ \\
Sobrinho & 1 & $0,4 \%$ & $2,4 \%$ \\
\hline Total Válido & 41 & $16,9 \%$ & \\
\hline Missing & 202 & $83,3 \%$ & \\
\hline Total & 243 & $100,0 \%$ & \\
\hline
\end{tabular}

Verificamos, na tabela 5 , que $26,8 \%$ das concessões com vínculo indireto se deram para os filhos do ocupante do cargo municipal. Segue a categoria de genro como segunda, com $24,4 \%$ e a terceira correspondendo a $14,6 \%$ para os irmãos.

De maneira geral, notamos que há uma distribuição proporcional entre parentes de sangue, como filho, irmão, pai e sobrinho e parentes por casamento, como sogro, genro, esposa, cunhado, marido de viúva e filha de genro.

As relações de sangue são facilmente compreensíveis se levarmos em conta a ideia de preservação de um grupo familiar e do fortalecimento de uma elite política local. Porém, o que nos chamou atenção foi que $24,4 \%$ dos casos com vínculo indireto serem de requerentes que, casaramse com filhas dessa elite política, sendo seus genros. Tal situação nos leva a pensar como se dava a visão em relação aos cargos, da administração e da sociedade para esses grupos. A utilização dos cargos para obter vantagens, materiais e imateriais, foi estabelecida por Max Weber ${ }^{356}$ como uma interpretação patrimonialista da sociedade e acreditamos que essa possa ser aplicada no contexto de São Paulo colonial.

O uso da propriedade municipal, doando-a para genros, pode ser considerada, como limite da concepção patrimonialista, pois utilizaram-se do cargo a fim de fornecer uma espécie de dote 
para o casamento da filha; concessão que permite que a filha tenha, através de seu marido, uma propriedade e, dessa forma, uma vida mais tranquila.

As relações familiares nos levaram a ponderar as relações de gênero para as concessões de terra. Afonso de Taunay $^{357}$ afirma em 1921 que as datas de terras destinavam-se também às mulheres.

\begin{tabular}{l|l|l}
\hline \multicolumn{3}{c}{ Tabela 6 - Concessões por Gênero } \\
\hline & Frequência & Porcentagem \\
\hline Masculino & 232 & $94,47 \%$ \\
Feminino & 11 & $4,53 \%$ \\
\hline Total & 243 & $100,00 \%$ \\
\hline
\end{tabular}

No entanto, conforme verificamos na tabela 6 , apenas $4,53 \%$ das concessões foram requeridas por mulheres. Tal situação nos levou a analisar esses 11 casos de forma qualitativa.

Verificando as Cartas de Datas de Terra, notamos que os poucos casos de mulheres solicitando terras se deu pelo fato dessas não terem parentes homens para solicitar. Muitas são viuvas e sozinhas e utilizam o prestígio do marido falecido para requerer as propriedades.

Maria Affonso ${ }^{358}$, ao requerer terras em 1583, apresenta-se como viuva de Marcos Fernandes. Outro caso que aponta na mesma direção é o de Isabel Rodrigues ${ }^{359}$, que solicita terras em 1598, com o argumento de que precisa agasalhar seus filhos e que seu marido Antonio Rodrigues encontra-se ausente.

O contexto de $94,47 \%$ das solicitações terem sido requeridas por homens é reflexo da sociedade patriarcal, em que a posse de uma propriedade era de extrema importância política e social e deveria ser masculina.

357 Afonso de Taunay. São Paulo nos primeiros anos e São Paulo no século XVI. São Paulo: Paz e Terra, 2003, p. 111. 358 Carta IV. Cartas de datas de terra. São Paulo: Departamento de Cultura, 1937, vol. I. 


\section{$3^{\text {a }}$ Problemática}

Após apresentada a relação entre poder local, parentesco e concessões de terra, realizamos a análise das argumentações dessas solicitações.

Afonso de Taunay, em São Paulo nos primeiros anos, de 1921, afirma que o pedido de terras em São Paulo colonial era pautado pela pobreza, pela necessidade decorrente da falta de recursos e pela necessidade de povoamento da terra ${ }^{360}$. Em estudo mais recente, Raquel Glezer afirma que, para a data de terra, "o pedido baseava-se na necessidade, na pobreza, no morar na vila, na troca de serviços com a Câmara etc" ${ }^{361}$.

\section{Tabela 7 - Padrões de Argumentação nas Solicitações de Terra}

\begin{tabular}{|c|c|c|c|}
\hline & Frequência & Porcentagem & Porcentagem Válida \\
\hline Guerra & 2 & $0,8 \%$ & $0,9 \%$ \\
\hline Recompensa & 33 & $13,6 \%$ & $15,2 \%$ \\
\hline Regularização & 31 & $12,8 \%$ & $14,3 \%$ \\
\hline Casamento com órfã & 3 & $1,2 \%$ & $1,4 \%$ \\
\hline "Nobreza da terra" & 14 & $5,8 \%$ & $6,5 \%$ \\
\hline Casamento com "nobreza da terra" & 9 & $3,7 \%$ & $4,1 \%$ \\
\hline Necessidade & 67 & $27,6 \%$ & $30,9 \%$ \\
\hline Morador Antigo & 17 & $7,0 \%$ & $7,8 \%$ \\
\hline Serviço de S. Majestade & 3 & $1,2 \%$ & $1,4 \%$ \\
\hline Serviço de Deus & 4 & $1,6 \%$ & $1,8 \%$ \\
\hline Licença para moinho & 4 & $1,6 \%$ & $1,8 \%$ \\
\hline Licença para minas & 1 & $0,4 \%$ & $0,5 \%$ \\
\hline Correição do ouvidor geral & 8 & $3,3 \%$ & $3,7 \%$ \\
\hline Costume & 3 & $1,2 \%$ & $1,4 \%$ \\
\hline Ocupar terras devolutas & 11 & $4,5 \%$ & $5,1 \%$ \\
\hline Aumento da cidade & 4 & $1,6 \%$ & $1,8 \%$ \\
\hline Provisão & 1 & $0,4 \%$ & $0,5 \%$ \\
\hline Serviço do povo & 2 & $0,8 \%$ & $0,9 \%$ \\
\hline
\end{tabular}

360 Afonso de Taunay. op. cit., p. 108.

361 Raquel Glezer. op. cit., p. 58. 


\begin{tabular}{l|l|l|l}
\hline Total Válido & 217 & $89,3 \%$ & $100,0 \%$ \\
\hline Missing & 26 & $10,7 \%$ & \\
\hline Total & 243 & $100,0 \%$ & \\
\hline
\end{tabular}

No entanto, ao verificar de forma quantitativa, os padrões de argumentação notamos que $30,9 \%$ das solicitações apontavam necessidade como argumento. 15,2\% apontavam recompensa como motivo para o pedido, seguindo de 14,3\% que alegavam regularização das propriedades já ocupadas.

O aparecimento das categorias recompensa, serviço de S. Magestade e serviço de Deus, reforçam a interpretação do uso patrimonialista das terras municipais.

É importante problematizar melhor o que é apontado como necessidade nas argumentações. Uma leitura rápida pode nos levar à ideia de que necessidade, tal como usamos o termo atualmente, refere-se à pobreza. Porém, lendo de forma qualitativa as cartas de datas de terra, notamos que necessidade é termo empregado em diversas concepções e, muitas vezes foi solicitada mais terras simplesmente por precisar de mais espaço, em decorrência de crescimento do número de cabeças de gado, por exemplo.

Vemos, portanto, que necessidade diz respeito ao precisar de terras no sentido mais evidente do termo. Não cabe fazer a associação de necessidade com carência e pobreza.

Voltando à tabela, vemos que para 6,5\% das concessões, utilizou-se como argumentação o fato do requerente ser da "nobreza da terra" e 4,1\% ter casado com a referida categoria. Esses casos, embora não tenham importância quantitativa, nos fornecem uma importante noção, se pensarmos de forma qualitativa. O termo "nobreza da terra", tal como definiu M. Beatriz Nizza da Silva $^{362}$, diz respeito a uma categoria social auto-definida, pautada pela tradição, no sentido de afirmar-se como uma elite local. Tal interpretação é reforçada com os 7,8\% das argumentações pautarem-se na antiguidade das familias. 
A porcentagem de 5,1\% das argumentações, referindo-se a ocupar terras devolutas, deve-se ao fato da legislação sobre propriedades municipais exigir que a posse de terras seja efetivada pela ocupação, sob o risco do requerente perder a propriedade ${ }^{363}$.

\section{$4^{\text {a }}$ Problemática}

A quarta problemática refere-se à ponderação da influência da cultura letrada na sociedade de S. Paulo colonial.

\begin{tabular}{l|l|l}
\hline \multicolumn{3}{c}{ Tabela 8 - Terras concedidas aos escrivães } \\
\hline & Frequência & Porcentagem \\
\hline Sim & 233 & $95,9 \%$ \\
Não & 10 & $41,0 \%$ \\
\hline Total & 243 & $100,0 \%$ \\
\hline
\end{tabular}

Analisando a tabela 8 , verificamos que somente $4,1 \%$ das concessões foram efetuadas aos escrivães da Câmara. A grande maioria dos responsáveis pelo registro das sessões municipais não foi contemplada com a distribuição de terras.

Isso nos faz pensar que a lógica de que quem detém a escrita possui certo poder tem sentido para sociedades em que a elite dirigente detém a capacidade de leitura ${ }^{364}$. Na sociedade lusoamericana pré-pombalina ${ }^{365}$, em que a maioria da população não era letrada, incluindo os administradores locais das vilas, não era o conhecimento formal que definia seus papéis na sociedade.

363 Afonso de Taunay. op. cit, p. 110.

364 Elite dirigente local letrada, tal como ocorreu nas cidades hispano-americanas. Cf. Ángel Rama. A cidade e as letras. São Paulo: Brasiliense, 1985, p. 41-53.

365 Usamos o ano de 1772, que marca a Reforma nos Estatutos Pombalinos como referencial pois a mesma introduz, nos Cursos Jurídicos da Universidade de Coimbra, a exigência do estudo das Ordenações do Reino. Inicia-se, a partir desse momento, o predomínio do direito escrito sobre a tradição oral. É de Pombal a instauração de juízes de fora, que são magistrados letrados e externos à comunidade local. Para maiores detalhes ver Estatutos da Universidade de Coimbra (1772). Coimbra: Universidade de Coimbra, 1972, livro II. 
A sociedade colonial, profundamente pautada pelas categorias sociais, influenciou sobremaneira a estruturação das câmaras municipais.

\section{$5^{\text {a }}$ Problemática}

Em continuidade às problemáticas referentes às relações entre poder político e as concessões de terras do termo de São Paulo, torna-se imprescindível que ponderemos sobre os cargos honorários.

Conforme discutimos anteriormente, os cargos honorários eram aqueles que baseavam-se na honra, no servir à republica. Não eram, portanto, remunerados, como ocorria com os demais.

\section{Tabela 9 - Concessões de terra feitas para ocupantes de cargos honorários}

\begin{tabular}{l|l|l|l}
\hline & Frequência & Porcentagem & Porcentagem Válida \\
\hline Sim & 156 & $64,2 \%$ & $96,3 \%$ \\
Não & 6 & $2,5 \%$ & $37,0 \%$ \\
\hline Total Válido & 162 & $66,7 \%$ & $100,0 \%$ \\
\hline Missing & 81 & $33,3 \%$ & \\
\hline Total & 243 & & \\
\hline
\end{tabular}

Juízes ordinários, vereadores e procurados do concelho pertenciam a essa categoria definida por Hespanha ${ }^{366}$. Os titulares dos cargos honorários apareceram com 96,3\% das concessões de terras com requerentes com vínculo, direto ou indireto, com o poder municipal.

Tais dados reforçam a interpretação levantada pelo autor citado, de que os oficiais honorários, apesar de não serem oficialmente remunerados, recebiam, em troca de seus serviços, vantagens materiais e distinções sociais.

Essa situação, de uso da propriedade municipal como sendo dos membros da administração 
local, reforça a interpretação patrimonialista dos cargos.

Dessa forma, podemos afirmar que a concessão de terras pela Câmara de São Paulo, apesar da aparência documental, não era destinada a pobres e com intuito único de povoamento, tal como descreve Taunay.

As concessões eram, conforme podemos verificar a partir dos dados apresentados, destinadas ao grupo de destaque, relacionado à elite política local. O uso do patrimônio municipal como forma de recompensar os serviços prestados reforça a interpretação historiográfica que a concentração fundiária e a relação íntima entre propriedade e poder não é algo recente no Brasil, mas remonta aos primórdios do processo de colonização.

\section{6 ${ }^{\mathrm{a}}$ Problemática}

A problemática da localização espacial das propriedades doadas, como afirmamos, não poderia nos dar, a princípio, informações muito relevantes.

\begin{tabular}{l|l|l}
\hline \multicolumn{3}{c}{ Tabela 10 - Localização das concessões de terra } \\
\hline Aldeia de S. Miguel & Frequência & Porcentagem \\
Aldeia de N. Senhora da Conceição & 17 & $7,0 \%$ \\
Aldeia de Barueri & 3 & $1,2 \%$ \\
Rossio de São Paulo & 5 & $2,1 \%$ \\
Limites com vila de Parnaíba & 192 & $79,0 \%$ \\
Carapicuíba & 1 & $0,4 \%$ \\
"Terras de Índios” & 1 & $0,4 \%$ \\
\hline Total & 24 & $9,9 \%$ \\
\hline & 243 & $100,0 \%$ \\
\hline
\end{tabular}

Verificamos que $79,0 \%$ das concessões ocorreram na área do rossio do município, seguidas das ocupações de "terras de índios", principalmente das terras da aldeia de S. Miguel e Barueri.

Contudo, conforme indica Raquel Glezer, o rossio do município de São Paulo somente fora 
definido e demarcado em $1769^{367}$, o que torna impossível definir realmente se as terras referidas eram no rossio ou não. A questão torna-se ainda mais complexa se lembrarmos que cabia à Câmara conceder terras a moradores dentro de seu rossio. Com isso, para que os pedidos de terra se enquadrassem na legislação vigente, os pedidos deveriam ser, necessariamente, de terras situadas dentro do rossio, mesmo que tal informação fosse meramente formal, visto que a extensão espacial dessa área era desconhecida à época.

Diante dessa situação, procuramos analisar os dados referentes à localização em uma outra perspectiva. Procuramos, dessa forma, cruzá-los com os dados referentes aos cargos honorários.

A partir desses dados, verificamos no gráfico 1 que $100 \%$ das propriedades foram concedidas a ocupantes de cargos honorários em terras fora do rossio, principalmente nas terras da aldeias de S. Miguel, de N. Senhora da Conceição e de Barueri.

As datas de terras fora do núcleo urbano são caracterizadas por possuírem, em média, uma dimensão espacial maior do que as próximas do núcleo urbano.

Por volta de 1660, a Câmara de São Paulo passou a invocar a seu favor uma provisão de Diogo Luís de Oliveira, governador-geral de 1627 a 1635, a qual concedia autorização de se repartirem entre os moradores as terras dos índios, desde que esses não fossem prejudicados ${ }^{368}$, conforme Bomtempi. Tal postura intensificou, segundo ele, a ocupação das terras da aldeia de S. Miguel. A posse de moradores, há muito instalados, não correspondia ao título de propriedade, visto que não cabia à Câmara a jurisdição das terras da aldeia.

367 Raquel Glezer. op. cit., p. 111.

368 Cf. Sylvio Bomtempi. O bairro de São Miguel Paulista. São Paulo: DPH, 1970, p. 64. 

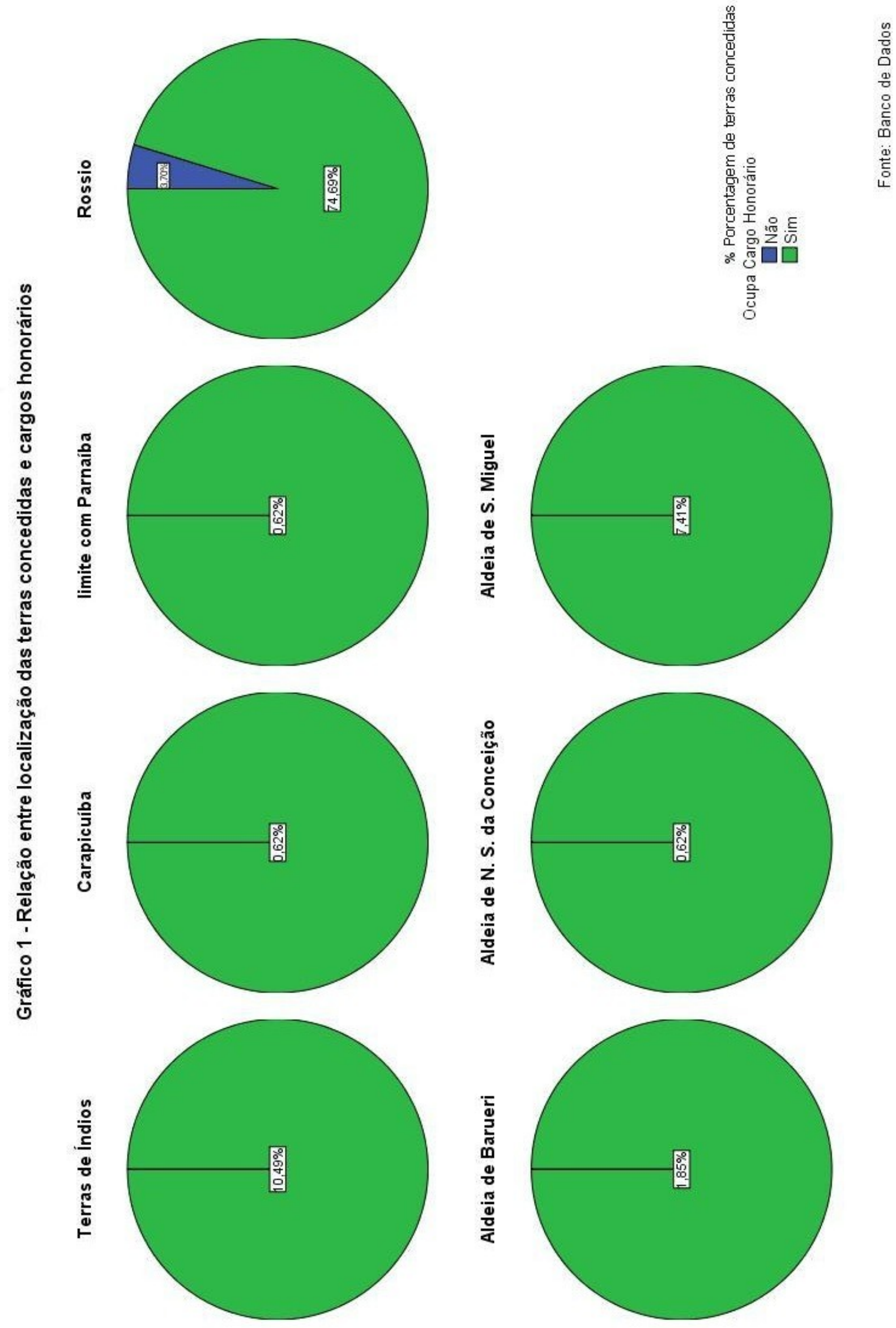

홍오

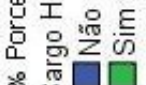

॰ 늄 $\square \square$ 莺
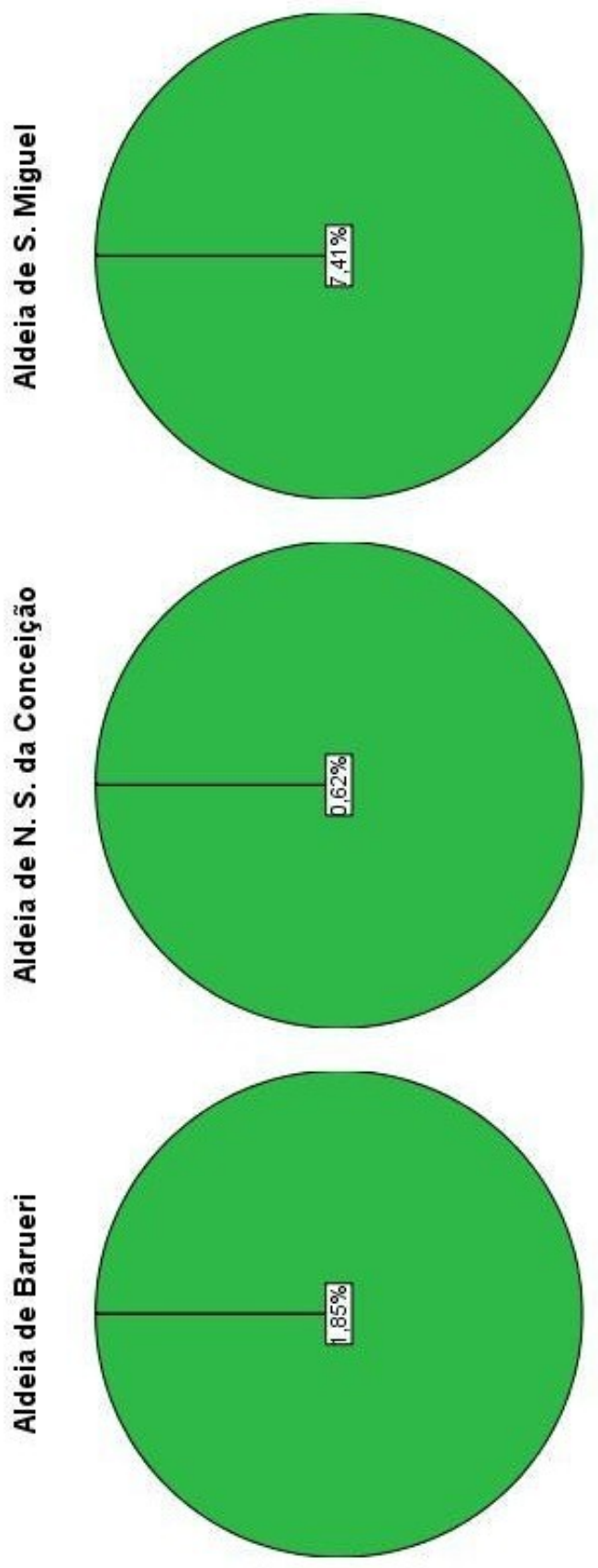
Em 1679, o ouvidor-geral João da Rocha Pitta, em diligências de correição na Capitania de São Paulo, determinou, diante das constantes invasões das terras indígenas de São Miguel, que caberia à Câmara de São Paulo administrar o aldeamento. Com isso, as terras da aldeia de São Miguel tornaram-se oficialmente patrimônio da vila de São Paulo, podendo, dessa forma, a edilidade conceder títulos de propriedade na região ${ }^{369}$.

As propriedades maiores e mais afastadas da área urbana eram, na sua maioria, destinadas à atividades econômicas agrárias mais do que no povoamento com casas para moradia. A legitimação legal das propriedades ocupadas em terras indígenas, através da correição do ouvidor ${ }^{370}$, garantiu uma expansão considerável da propriedade fundiária do município.

Nessa expansão foi contemplado exclusivamente o grupo de destaque na Câmara Municipal, tais como juízes ordinários, vereadores e procuradores do Concelho e seus familiares. Panorama esse que definiu claramente a concentração fundiária como situação intimamente relacionada a grupos políticos locais.

\section{$7^{\text {a }}$ Problemática}

A sétima e última problemática corresponde às relações entre dimensão das propriedades doadas e poder político local. Para tanto, definimos quatro categorias descritivas para dimensão, conforme já apresentamos.

Dividimos essa problemática em 3 eixos de análise. O primeiro corresponde à relação entre a localização e a extensão das propriedades concedidas.

Analisando o gráfico 2, notamos que somente encontramos pequenas propriedades nas áreas atribuídas ao rossio do município, sendo que essa categoria corresponde à metade das terras 
concedidas nessa área. Para as propriedades consideradas médias, localizamos a totalidade de terras doadas na região de Carapicuíba e pouco menos da metade das terras do rossio. As propriedades definidas como grande correspondem à totalidade nas terras doadas na aldeia de N. Senhora da Conceição, à maioria da aldeia de São Miguel e à mais da metade em terras descritas genericamente como "terras de índios". As propriedades com mais de 500 braças quadradas, definidas como muito grandes, foram encontradas em menos de $1 / 4$ das ditas "terras de índios" e na totalidade das terras doadas na aldeia de Barueri.

Diante desse panorama, verificamos que a concessão de datas de terras no rossio correspondeu, tal como apresentou a historiografia, à propriedades pequenas e médias, raramente ultrapassando 100 braças quadradas.

As maiores propriedades foram concedidas em "terras de índios", notadamente nas aldeias de S. Miguel, N. Senhora da Conceição e Barueri. Tal situação ocorreu no último quartel do século XVIII pelo fato das terras indígenas terem sido incorporadas ao patrimônio do município em 1679, e essa incorporação, de 6 léguas quadradas, que correspondia a extensão do termo do município, propiciar uma substancial expansão das concessões de grande extensão ${ }^{371}$. 


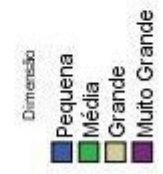
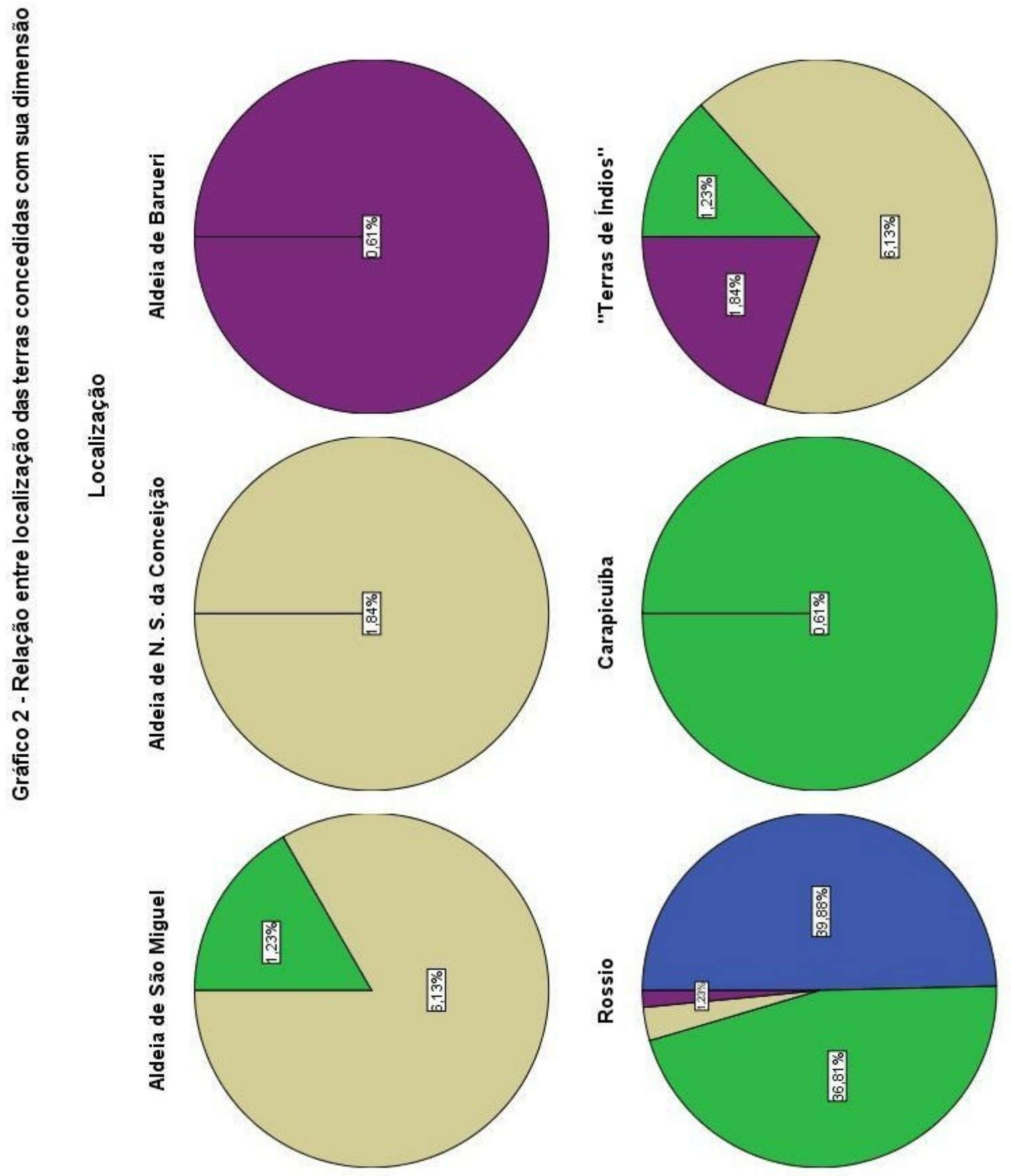


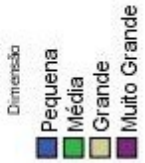
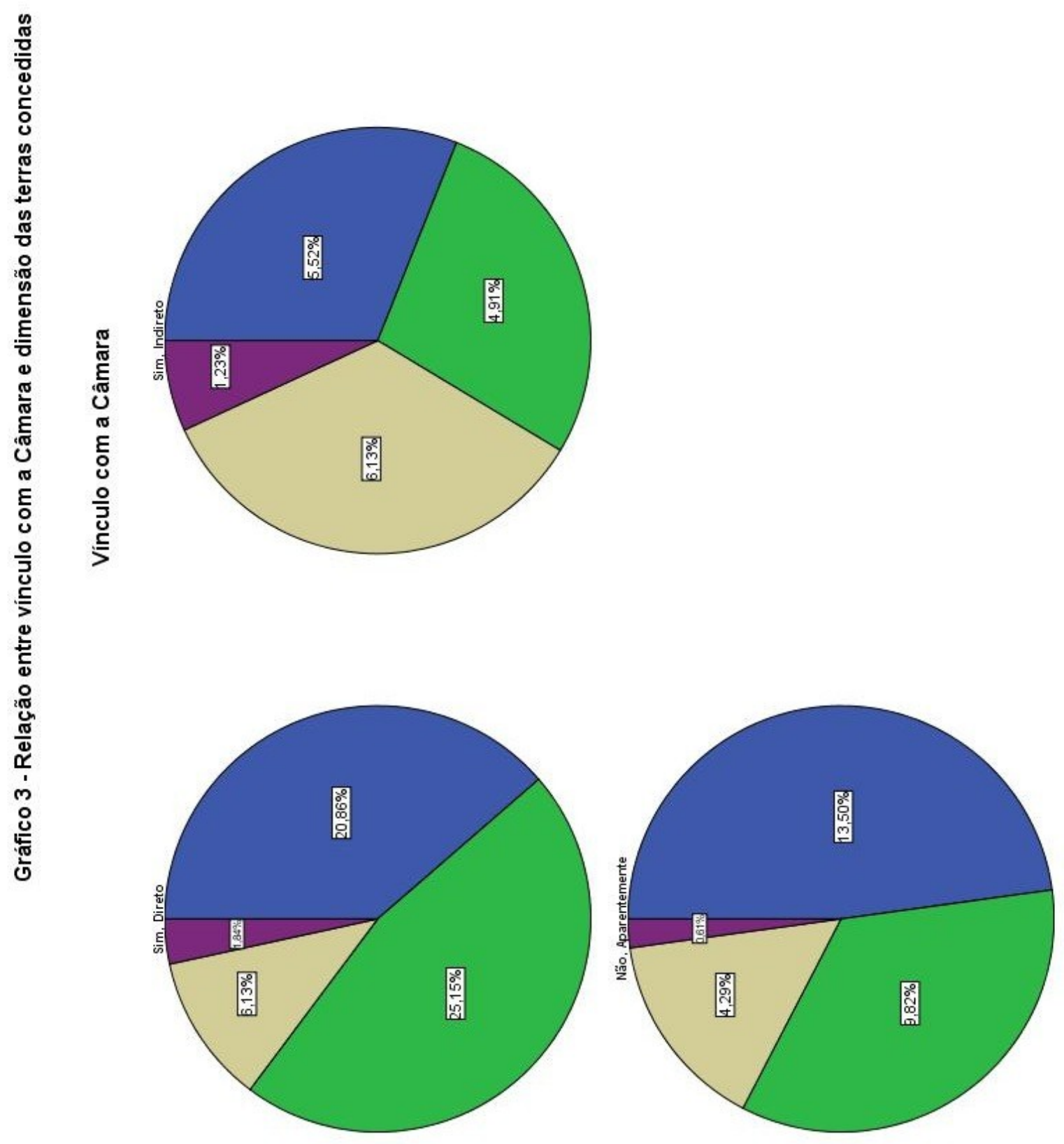


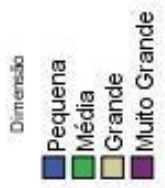
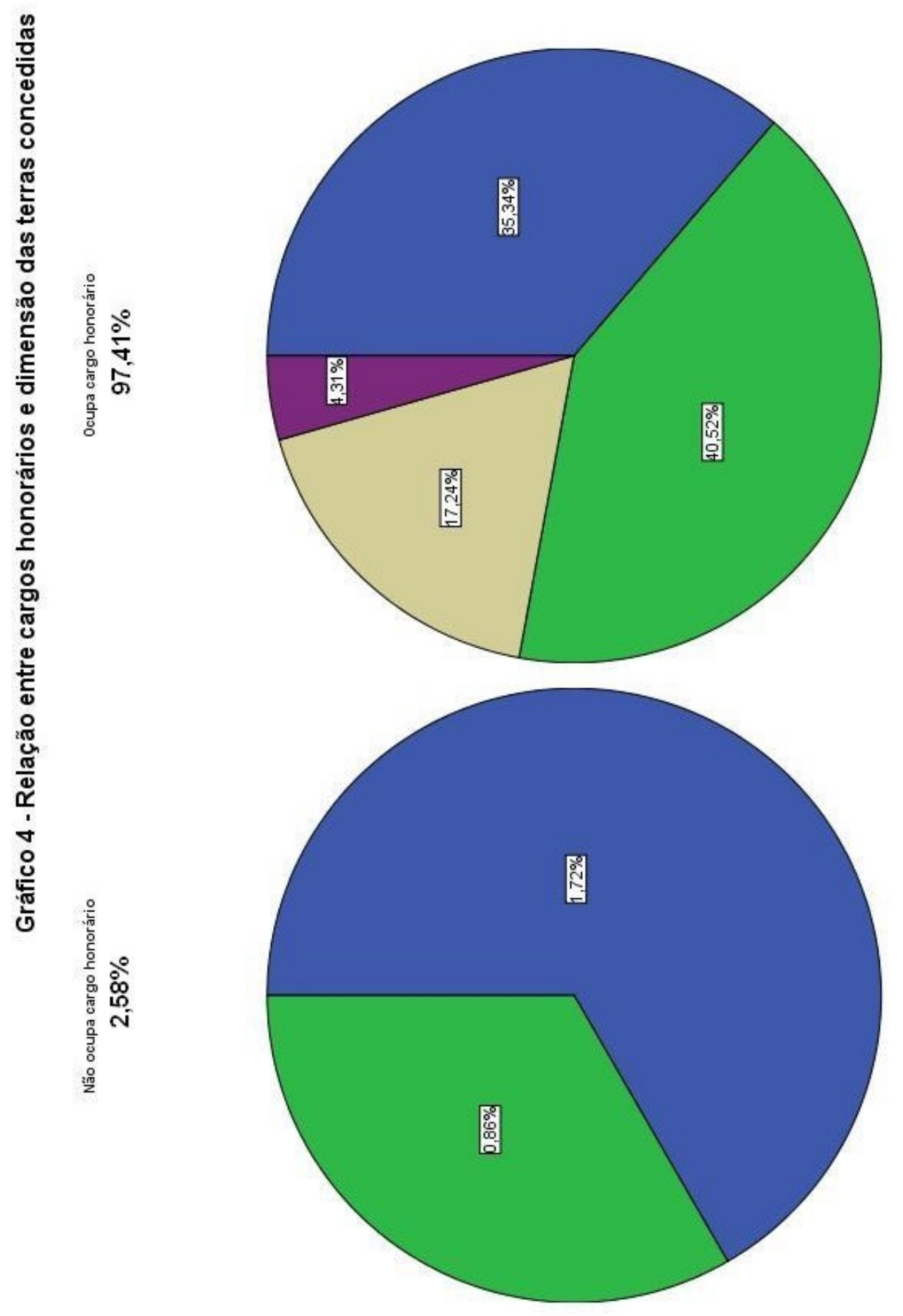
O segundo eixo corresponde à verificação da relação entre dimensão da propriedade e vínculo ocupado na câmara municipal.

Analisando o gráfico 3, notamos que as menores propriedades, pequenas e médias, concentram-se em indivíduos que não possuíam, aparentemente, vínculos com poder local. As maiores propriedades correspondem, dessa forma, à indivíduos com vínculos diretos e indiretos.

Porém, conforme já apontamos, devemos analisar as relações políticas e sociais de acordo com as categorias de sua época. Para tanto, definimos, como terceiro eixo, a análise da relação entre dimensão de terra concedida e cargo honorário na administração local.

Para o gráfico 4, notamos que para os cargos não honorários, como porteiro, escrivão e almotacel, por exemplo, a maioria das concessões de datas de terras corresponde à pequenas propriedades, seguidas pelas médias. Somente encontramos casos de propriedades grandes e muito grandes para concessões a membros de cargos honorários.

Tal panorama reforça a interpretação que os oficiais da câmara conceberam o patrimônio da Câmara como se fosse sua propriedade. Dessa forma, servir à câmara permitia que se usasse do seu patrimônio como forma de recompensa por serviços prestados ao bem comum. 


\section{Capítulo 3}

\section{Patrimonialismo e Poder Local}

No sul, porém, e particularmente nos lugares à volta de Piratininga, vencidas as escabrosidades da serra, a paisagem vai ganhar outro colorido. Não há aqui a coesão externa, a aparência de equilíbrio, oferecida pelos núcleos surgidos no litoral nordestino, nas terras do massapé gordo, onde, bem ou mal, se exprime a riqueza na sólida habitação do dono de engenho. Aquela sociedade meio aluvial constituída no planalto vicentino irá manter-se ainda por dois séculos ou mais em situação instável e imatura, que deixa espaço ao maior intercurso com a gente nativa. Sua vocação está no caminho, que convida ao movimento, não na grande lavoura, que cria indivíduos sedentários.

Sérgio Buarque de Holanda ${ }^{372}$ 
Nesse capítulo iremos abordar a questão do poder local no espaço colonial português na América, as características do traçado urbano da vila de São Paulo e como a estruturação das câmaras no planalto influenciou a fundação de novas vilas.

Essas discussão foram possíveis a partir dos resultados obtidos com a quantificação dos dados referentes à concessão de terras urbanas na vila de São Paulo.

\section{1 - O poder local no espaço colonial português na América: o caso de São Paulo}

\section{A Câmara Municipal}

O sistema administrativo por câmaras municipais foi implantado logo no início do processo de colonização portuguesa, sendo São Vicente o primeiro município, fundado em 1532.

Nas palavras de Edmundo Zenha, “a vila era a maneira mais fácil do português compreender a colonização" ${ }^{\text {373 }}$ e nada mais fácil do estender às novas terras a base da organização administrativa portuguesa.

Charles Boxer afirma que a Câmara Municipal era composta, no período colonial,

de dois a seis vereadores, conforme o tamanho e a importância do local, dois juízes ordinários (magistrados ou juízes de paz sem formação em direito) e o procurador. Todos tinham direito a voto nas reuniões do conselho e eram conhecidos coletivamente como oficiais da câmara. O escrivão, embora inicialmente não tivesse direito de voto, muitas vezes se incluía entre os oficiais. ${ }^{374}$

A Câmara municipal era composta também de funcionários subalternos da municipalidade e, por não serem os oficiais da câmara, não tinham direito a voto. Boxer apresenta esses como sendo 
os almotacéis, ou inspetores de mercados; os juízes de órfãos, que cuidavam dos interesses dos órfãos e das viúvas; os alferes, ou porta-bandeira, cujo cargo podia acumular-se com o de escrivão; o porteiro, que muitas vezes trabalhava como arquivista; o carcereiro; e , nas cidades grandes, o vedor de obras ou fiscal das obras públicas. ${ }^{375}$

Devido a essa separação em categorias, Boxer, defende que "os vereadores e juízes ordinários, a princípio não faziam parte do pessoal assalariado, mas gozavam de privilégios consideráveis durante seus mandatos" ${ }^{376}$.

Essa diferenciação se deu pela origem dos cargos administrativos dos municípios portugueses. Edmundo Zenha afirma, que, nos primeiros séculos dos municípios, os membros da governança eram escolhidos entre os homens-bons, que consistiam em uma "corporação de pessoas gradas que se destacavam na comunidade já pela riqueza, já pela experiência ou força intelectual, já pelo exercício anterior de algum cargo municipal" 377.

Com a publicação das Ordenações Afonsinas, em 1446, surge, pela primeira vez, o termo vereador $^{378}$, substituindo os homens-bons em inúmeras funções. Segundo Zenha, essa era a forma de participação indireta do povo nas questões do concelho, uma vez que, "pela maneira anterior, com os homens-bons, o povo tomava parte direta na administração e nas reuniões de mor importância para a vida local”379380.

O processo eleitoral, que consistia na escolha dos membros da instituição por meio de eleição direita, também foi estabelecido pelas legislações gerais do reino ${ }^{381}$. Não iremos, contudo,

375 Charles Boxer. op. cit., p. 387.

376 Charles Boxer. op. cit., p. 287.

377 Edmundo Zenha. op. cit., p. 16.

378 Ordenações Afonsinas, liv. I, tít. XXVII.

379 Edmundo Zenha. op. cit., p. 18.

380 Para uma discussão sobre os efeitos das Ordenações Afonsinas nos municípios, ver Max Fleiuss. História Administrativa do Brasil. São Paulo: Melhoramentos, 1922, p. 33 e João Martins de Carvalho Mourão. Os municípios. Revista do Instituto Histórico e Geográfico Brasileiro, tomo de 1914, parte III.

381 Para a descrição do processo eleitoral das câmaras, ver Ordenações Manuelinas, liv. I , tít. XLV e Ordenações Filipinas, liv. I, tít. LXVII. 
descrever as minúcias do processo eleitoral, visto que o tema já foi explorado pela historiografia ${ }^{382}$. O que podemos ressaltar em relação ao processo é que foi apontado pela historiografia como sendo o fator principal de democracia local, visto que os moradores da vila exerciam seu governo através de representantes eleitos e não impostos por nomeações externas ${ }^{383}$.

Assim, Brasil Bandecchi apresenta "as Câmaras municipais, oriundas do voto local, como representantes legítimas das forças sociais atuantes e os mais respeitáveis órgãos de opinião pública" ${ }^{384}$.

O município no mundo colonial pode ser considerado como o alicerce do processo de ocupação da América Portuguesa. Tal importância se expressa na célebre frase de Charles Boxer, que afirma "que a câmara e a misericórdia podem ser descritas, com algum exagero, como os pilares gêmeos da sociedade colonial do Maranhão até Macau"385. Edmundo Zenha, por sua vez, ressalta que "não se criam municípios no Brasil para a realização de obras públicas. Os povos, quando os pedem, querem policiar a terra, implantar nela um organismo distribuidor de justiça porque a del-rei era distante, demorada e cara" ${ }^{386}$.

Devido a sua importância no processo de colonização, principalmente no seu início, quando as instituições governamentais metropolitanas no mundo colonial não haviam se estabelecido, não é de se espantar que as câmaras tivessem papel político de destaque.

Segundo Laima Mesgravis, para o exercício do poder nas câmaras "era preciso ser 'homem bom', 'um dos principais da terra', 'andar na governança', 'viver à lei da nobreza', 'tratar-se nobremente', 'ser limpo de sangue' e 'não padecer de acidentes de mecanismo"'387.

Todavia, não encontramos, ainda mais no início da colonização na capitania vicentina,

382 Para uma descrição do processo eleitoral, ver Afonso d'E. Taunay. São Paulo nos primeiros anos e São Paulo no século XVI. São Paulo: Paz e Terra, 2003, p. 36-40 e Manoel Rodrigues Ferreira. A evolução do sistema eleitoral brasileiro. Brasília: Senado Federal, 2001, p. 45-49.

383 Autores como Edmundo Zenha e Brasl Bandecchi.

384 Brasil Bandecchi. O município no Brasil e sua função política. São Paulo: s.n., 1964, p. 497.

385 Charles Boxer. op. cit.,p. 286.

386 Edmundo Zenha. op. cit., p. 31.

387 Laima Mesgravis. Os aspectos estamentais da estrutura social no Brasil colônia. Estudos Econômicos. São Paulo: IPE-USP, 1983, vol. 13 (número especial), p. 799. 
pessoas que se enquadrassem nessas categorias restritas para ocupar cargos municipais. A necessidade de ocupar e de organizar a administração local forçou a relativização da observação a essas regras. Não que tenham sido questionadas, mas foram ignoradas devido à impossibilidade prática de cumpri-las.

Edmundo Zenha aponta que “os descendentes dos primeiros colonos já surgiam nobilitados pela ascendência uma vez que o título de povoador tornou-se quase um privilégio e ser oriundo dele implicava não poucas vantagens" ${ }^{388}$.

Nas palavras de Zenha, “o Senado da Câmara passou a ser resumo das famílias dominantes, e o seu mais autorizado porta-voz. E foi sustentado pela família colonial que o município tornou-se no Brasil tão prestigioso, às vezes arrogante, outras revolucionário"389.

As Câmaras no Império português, por vezes, recebiam títulos de Senado. Charles Boxer relata que

\begin{abstract}
Goa recebeu os privilégios de Lisboa; Macau, os de Évora; Bahia, Rio de Janeiro, Luanda e muitas outras, os do Porto. Não se sabe ao certo porque os privilégios da cidade do Porto eram os mais procurados, visto que a referência à primeira edição impressa dos Privilégios dos cidadãos da cidade do Porto (1611) mostra que eram idênticos e copiados textualmente dos de Lisboa. ${ }^{390}$
\end{abstract}

Edmundo Zenha descreve que "tais privilégios foram concedidos a São Luís do Maranhão, São Sebastião, Salvador, Belém e São Paulo" ${ }^{391}$. Em relação a São Paulo, Brasil Bandecchi informa que o título de Senado fora concedido em 1730, sendo esses iguais aos privilégios do Porto ${ }^{392}$.

Maria Fernanda Bicalho, por sua vez, pondera mais detalhadamente sobre o referido título às câmaras. Ressalta que,

388 Edmundo Zenha. op. cit., p. 95.

389 Edmundo Zenha. op. cit., p. 132.

390 Charles Boxer. op. cit., p. 291-292.

391 Edmundo Zenha. op. cit., p. 101.

392 Cf. Brasil Bandecchi. op. cit., p. 31. 
uma primeira observação a se fazer acerca desses privilégios é o fato de serem concedidos aos cidadãos e não a todos os habitantes das cidades contempladas. Por cidadãos entendia-se aqueles que por eleição desempenhavam ou tinham desempenhado cargos administrativos nas câmaras municipais - vereadores, procuradores, juízes locais, almotacéis etc -, bem como seus descendentes. Entre as prerrogativas a que tinham direito estavam as distinções de não serem metidos a tormentos por quaisquer malefícios que tivessem cometido, salvo nos modos em que eram os fidalgos do reino; de não poderem ser presos por nenhum crime, somente como eram e deviam ser os mesmos fidalgos, e de lhes ser permitido portar quaisquer tipo de armas. ${ }^{393}$

A importância das câmaras municipais no mundo colonial se deu, principalmente, pelo fato de terem área de delimitação espacial, o seu termo, não submetida a nenhum senhorio, mesmo donatarial, apenas ao rei. De acordo com Raimundo Faoro,

o município, arma comum à estratégia política da realeza na Europa, mereceu especial estímulo, na mesma medida em que se enobreciam os potentados rurais. Os concelhos, conservados tenuemente pela tradição, no início desvinculados de carta de foral, pouco representavam, no curso dos dois primeiros séculos da monarquia portuguesa. Temerosa do domínio autônomo das camadas que a apoiavam - o clero e a nobreza - a realeza deslocou sua base de sustentação, criando as comunas e estimulando as existentes, no incremento da realidade capaz de lhe proporcionar suporte político, fiscal e militar. ${ }^{394}$

De acordo com António Vasconcelos de Saldanha, "o estabelecimento do termo implicava, não apenas a mera delimitação geográfica e jurisdicional da vila, mas uma real concessão de terras transferida para a directa tutela da mesma" ${ }^{395}$.

Com isso, "tal como os donatários distribuíam determinada porção de solos aos colonos,

393 Maria Fernanda B. Bicalho. A cidade e o império. Rio de Janeiro: Civilização Brasileira, 2003, p. $322-323$. 394 Raimundo Faoro. Os donos do poder. Porto Alegre: Globo, 1958, p. 21-22.

395 António Vasconcelos de Saldanha. As capitanias. O regime senhorial na expansão ultramarina portuguesa.

Funchal: CEHA, 1992, p. 211. 
com o fim primacial do seu aproveitamento, faziam-no também àquelas [as câmaras] em benefício das utilidades e interesses das comunidades sob o preciso nome de sesmarias" ${ }^{\prime 396}$.

Edmundo Zenha, em relação às terras municipais, afirma que

ampliando seus quintais, os moradores apossavam-se paulatinamente das terras roceiras. Cada nova demarcação verificava a diminuição da área comum e, nos termos lavrados a respeito, o concelho tinha sempre a inteligência de respeitar semelhantes esbrulhos evitando demandas que lhe seriam caríssimas uma vez que os reús eram inúmeros. ${ }^{397}$

Contudo, conforme podemos observar no capítulo anterior, a utilização das terras municipais pela Câmara no caso da vila de São Paulo não correspondeu, contudo, à distribuição com intuito de povoar a terra. Nem mesmo, como aponta Saldanha, para a construção de casas, hortas ou simplesmente "para comer" 398.

Vimos a utilização das terras municipais como forma de recompensar moradores por serviços prestados à Câmara, tendo seus ocupantes administrado as terras como se fossem seu próprio patrimônio.

Tal situação não pode ser considerada apenas como formas de abuso ou excessos cometidos por alguns oficiais da Câmara. Vale retomar a discussão ocorrida em 5 de março de 1633 sobre acusações de ocupação de campos reguengos.

Esses campos são, nas palavras de Francisco de Souza e Sampaio "aquelles bens da Coroa adquiridos até o tempo do Senhor D. Pedro I, o quoaes gozão de certos privilegios, e liberdades, não só communs aos outros bens posteriormente adquiridos, chamados bens da Coroa, mas proprios e particulares ${ }^{399}$.

396 António Vasconcelos de Saldanha. op. cit., p. 211.

397 Edmundo Zenha. op. cit., p. 49-50.

398 António Vasconcelos de Saldanha. op. cit., p. 211-2.

399 Francisco Coelho de Souza e Sampaio. Prellecções de direito pátrio público e particular. Coimbra: Real Imprensa da Universidade, 1793, p. 62, $2^{\mathrm{a}}$ parte. 
E, conforme aponta Zenha, "o concelho tinha competência sobre uma determinada área que se chamava o termo. Este território sobre o qual se exercia a jurisdição municipal devia ter seis léguas, pelo menos, de uma vila a outra" ${ }^{4_{00}}$. Dessa forma, não competia à Câmara conceder terras fora de sua jurisdição, ainda mais se forem em propriedades pertencentes à Coroa.

$\mathrm{Na}$ sessão acima citada, foi "eformado que algûas pesoas se querião aposar dos campos realengos" ${ }^{401}$. Diante dessas denúncias, os oficiais da Câmara "mandarão que nenhûa pesoa de qualquer calidade e condisão que seja tome posesões dos ditos campos nem alugem a houtrem nem secular nem eclesiastiquo com pena de seis mil rs pera obras do conselho e a bula da cruzada" "402.

Observamos, portanto, que as terras que não pertenciam aos domínios da Câmara eram respeitadas, principalmente as terras reguengas. A concessão sistemática e ininterrupta de propriedades municipais no rossio e no termo do município exige que ponderemos melhor sobre essa questão. E, para tanto, devemos refletir sobre as relações de poder no contexto local da América Portuguesa.

\section{O patrimonialismo na administração local}

No ensaio A sociedade escravista no Brasil, de 1976, Florestan Fernandes apresenta as linhas gerais da evolução da estratificação social no Brasil, ressaltando a produção escravista. Aponta que

o esquema básico da sociedade estamental e de castas do período colonial repousa numa construção muito simples. Os portugueses transplantaram, para cá, a ordem social que tinha vigência em Portugal na época dos Descobrimentos e da Conquista. $\mathrm{O}$ que quer dizer que ocorreu uma formidável tentativa deliberada de preservação e de adaptação de todo um corpo de instituições e de padrões

400 Edmundo Zenha. op. cit., p. 45.

401 Atas da câmara da vila de São Paulo. São Paulo: Duprat \& Ca ., 1914, vol. XIV, p. 158.

402 Idem, p. 159. 
organizatórios-chaves, com vistas à criação de um 'novo Portugal' (expressão empregada pelo padre Cardim com referência a S. Vicente) que deveria emergir das condições sociais de uma colônia de exploração $0^{403}$.

Essa transferência da ordem estamental existente em Portugal foi permitida graças à relação patrimonial da sociedade portuguesa ${ }^{404}$. Contudo, antes de tratar da aplicação de ações patrimonialistas na colônia, devemos retomar à discussão de alguns conceitos.

Para Max Weber, a dominação tradicional ocorre "quando sua legitimidade repousa na crença na santidade de ordens e poderes senhoriais tradicionais ('existentes desde sempre')" ${ }^{405}$. E “determina-se o senhor (ou os vários senhores) em virtude de regras tradicionais. A ele se obedece em virtude da dignidade pessoal que lhe atribui a tradição" ${ }^{406}$.

Já a dominação patrimonial é “originalmente orientada pela tradição e se exerce em virtude da dignidade pessoal que lhe atribui a tradição" ${ }^{407}$.

Raymundo Faoro, em Os donos do poder, aplica a interpretação patrimonialista na formação de Portugal e, consequentemente, na evolução do Brasil. Afirma que as novas conquistas do reino formaram

o patrimônio do rei - o mais vasto do reino, mais vasto que o do clero e, ainda no século XIV, três vezes maior que da nobreza - [de onde] fluíam rendas para sustentar os guerreiros, os delegados monárquicos espalhados no país e o embrião dos servidores ministeriais, aglutinados na corte. Permitia, sobretudo, a dispensa de largas doações rurais em recompensa aos serviços prestados pelos seus caudilhos, recrutados, alguns, entre aventureiros de toda Europa. ${ }^{408}$

Segundo Rodrigo Ricupero, foi Florestan Fernandes o autor que melhor soube adaptar o

403 Florestan Fernandes. A sociedade escravista no Brasil. Circuito fechado., p. 31-32.

404 Florestan Fernandes. op. cit., p. 34.

405 Max Weber. Economia e sociedade. Brasília: EdUnB, São Paulo: Imprensa Oficial, 2000, vol. I, p. 148.

406 Max Weber. op. cit., p. 148.

407 Max Weber. op. cit., p. 152.

408 Raimundo Faoro. Os donos do poder. Porto Alegre: Globo, 1958, p. 19. 
conceito weberiano à história do Brasil, dedicando um tópico de seu ensaio às funções do patrimonialismo nas relações da Coroa com os vassalos no processo de colonização ${ }^{409}$.

Nas palavras de Florestan Fernandes,

uma Coroa pobre, mas ambiciosa em seus empreendimentos, procura apoio nos vassalos, vinculando-os aos seus objetivos e enquadrando-os às malhas das estruturas de poder e à burocracia do Estado patrimonial. Esse aspecto é deveras importante. Sem essa associação não haveria nem Império colonial português nem economia de plantação no Brasil. Por isso, o 'colonizador' ou o 'colono' é sempre um vassalo, um agente da Coroa e arca, por sua conta e risco, embora com alguns privilégios e vantagens e, por vezes, com algum suporte oficial, com a construção do Império na Colônia ${ }^{410}$.

A dominação patrimonial, tal como foi aplicada por Faoro e Fernandes foi definida no capítulo "Sociologia da Dominação", da Economia e sociedade. Nesse, Weber define dominação como sendo

uma situação de fato, em que uma vontade manifesta ('mandado') do 'dominador' ou dos 'dominados', e de fato as influencia de tal modo que estas ações, num grau socialmente relevante, se realizam como se os dominados tivessem feito do próprio conteúdo do mandado a máxima de suas ações ('obediência'). ${ }^{411}$

Com isso, "toda dominação manifesta-se e funciona como administração. Toda administração precisa, de alguma forma, da dominação, pois, para dirigi-la, é mister que certos poderes de mando se encontrem nas mãos de alguém" ${ }^{412}$.

Max Weber apresenta que

409 Rodrigo Ricupero. A formação da elite colonial. São Paulo: Alameda, 2009, p. 49.

410 Florestan Fernandes. op. cit., p. 34.

411 Max Weber. Economia e sociedade. Brasília: EdUnB, São Paulo: Imprensa Oficial, 1999, vol. II, p. 191.

412 Max Weber. op. cit., p. 193. 
as funções administrativas são simplesmente assumidas num sistema de turno ou conferidas mediante sorteio ou eleição direta, para curtos períodos de exercício, sendo reservadas aos membros da associação todas as decisões materiais, ou pelo menos as importantes, e deixadas com os funcionários somente a preparação e a execução das decisões e a chamada 'administração dos assuntos correntes', de acordo com as disposições da assembleia dos membros..$^{413}$

Em relação aos ocupantes da administração local, "quanto menos tempo disponível têm aqueles que exercem um trabalho profissional, tanto mais tende, numa situação de diferenciação social, a administração diretamente democrática a transformar-se numa dominação dos honoratiores" ${ }^{414}$. Os honoratiores são os vizinhos que se destacam por fortuna, educação qualificada e modo de viver e sua autoridade baseia-se, sobretudo, na honra ${ }^{415}$.

Seguindo a interpretação estabelecida por Weber, podemos concluir que, tal como apontaram Faoro e Florestan, a concepção patrimonialista, presente na Coroa portuguesa desde suas origens, pode ser estendida para o poder local.

Inserido nesse contexto, pautado no poder fundamental da tradição e na crença na inviolabilidade do "eterno ontem"416, o poder local, principalmente nas ações de seus oficiais, reproduziu tal comportamento dentro de área de sua jurisdição.

Podemos verificar a concepção patrimonialista dos edis da Câmara Municipal de São Paulo em relação às terras do termo do município, propriedade da Câmara. Concebido originalmente como forma de garantir liberdades dos moradores frente à pressões dos senhores feudais e donatariais e garantir uma posição de aliado do rei $^{417}$, passou a ser utilizada como mecanismo de auto-promoção dos oficiais da Câmara, principalmente para os que ocupavam cargos de destaque.

Essa prática, conforme pudemos verificar no capítulo anterior, teve predominância de ocorrências com oficiais que ocuparam os cargos honorários, isto é, os que não eram remunerados e 413 Max Weber. op. cit., p. 193.

414 Max Weber. op. cit., p. 194.

415 Max Weber. op. cit., p. 236.

416 Max Weber. op. cit., p. 235.

417 Cf. Raimundo Faoro. op. cit., p. 21-22. 
cuja atuação era baseada na honra que os ocupantes possuíam. Conforme António M. Hespanha, esses cargos

são desempenhados por titulares eventuais (e não de carreira) escolhidos pelas populações e, em princípio, não remunerados. O interesse do desempenho dos cargos estaria então no prestígio que lhes era inerente. Mas também, num plano menos imaterial, nas possibilidades de, usando da situação de preeminência social e política que eles garantiam, obter vantagens econômicas diversas. ${ }^{418}$

Isso porque, segundo Max Weber,

ao cargo patrimonial falta, sobretudo, a distinção burocrática entre a esfera 'privada' e a 'oficial'. Pois também a administração política é tratada como assunto puramente pessoal do senhor [ou de grupo, como as câmaras], e a propriedade e o exercício de seu poder político, como parte integrante de seu patrimônio pessoal, aproveitável em forma de tributos e emolumentos, ou inclusive, do uso da propriedade da instituição em proveito do grupo que cargos nela ocupa ${ }^{419}$.

Portanto, "os funcionários patrimoniais encontram originalmente seu sustento material típico, como todo membro da comunidade doméstica, na mesa do senhor, vindo das reservas deste" ${ }^{320}$.

No entanto, para continuar essa reflexão, é necessário que verifiquemos como os oficiais da Câmara de São Paulo atuavam e como se viam na sociedade colonial.

Laima Mesgravis afirma que, para ser "homem-bom" na colônia, mesmo que humilde, tem de basear-se na "afirmação dos valores aristocráticos do ócio e da ostentação e a condenação dos burgueses como o trabalho e o comércio"421.

418 António M. Hespanha. As vésperas do Leviathan. Coimbra: Almedina, 1994, p. 164.

419 Max Weber. op. cit., p. 253.

420 Max Weber. op. cit., p. 255.

421 Laima Mesgravis. op. cit., p. 801. 
Acrescente-se ainda a essa descrição, conforme apontamos na tabela 7 do capítulo 3.3, os padrões de argumentação na solicitação de terras. Justificativas baseadas em pertencer à "nobreza da terra" ou casar-se com membro dela reforçam essa nobilitação pretendida.

Maria Beatriz Nizza da Silva afirma ser

um dos temas preferidos da historiografia do Brasil colonial a relação entre riqueza e poder, convencionando-se chamar 'nobreza da terra' aqueles que, por oposição ao grupo mercantil, assentavam-se nas sesmarias recebidas, destinadas a engenhos ou fazendas de criatório, e no número de escravos possuídos os esteios de seu prestígio social. ${ }^{422}$

No entanto, consideramos o termo "nobreza da terra" limitado, pois, ao invés de expressar uma distinção social no âmbito local, pode levar a considerar separações aristocráticas. Raphael Bluteau define, no Vocabulario portuguez e latino, do séc. XVIII, nobre "aquelle que por sangue, ou por alvarà do Principe se differencia em honras, \& estimação, dos plebeos, \& mecanicos" ${ }^{423}$.

Mais do que apontar a sociedade colonial como um meio social altamente hierarquizado e pautado por relações de diferenciação social, pretendemos ressaltar que essa diferenciação era desejada por muitos. Contudo, a grande maioria não poderia requerer os direitos de nobreza, que devido à falta de recursos em empreender tarefa dispendiosa e demorada, quer por não ter argumentos válidos. Esses, embora tivessem destaque econômico e político na sociedade local, passaram a "viver nobremente", em uma evidente pretensão de nobreza.

Aliados a esses habitantes destacados, havia os descendentes dos primeiros povoadores. Verificamos no capítulo anterior que o vínculo com as mais antigas famílias era argumento utilizado na solicitação de terras. Em 1598, por exemplo, Pedro Nunes, Manuel Fernandes e Fernão Marques solicitam terras e argumentam que são "filhos de moradores e conquistadores antigos" 424 . Passando 422 M. Beatriz Nizza da Silva. Ser nobre na colônia. São Paulo: EdUNESP, 2005, p. 131.

423 Raphael Bluteau. Nobre. In: Vocabulário portuguez, e latino, aulico, anatomico, architectonico, bellico, botanico... et alii. Coimbra: Collegio das Artes da Companhia de Jesus, 1712, p. 730.

424 Carta L, LI e LII. Cartas de datas de terra de São Paulo. São Paulo: Departamento de Cultura, 1937, vol. I. 
algumas décadas, em 1640, Sebastião Fernandes Preto retoma a mesma argumentação, afirmando que "elle era filho e neto de povoadores e conquistadores desta villa" ${ }^{425}$. Mais uma vez, a ideia de descender dos conquistadores, termo esse que reveste a ocupação inicial de heroísmo e, portanto, nobilita seus executores, também foram base para a nobreza pretendida.

A obra genealógica de Pedro Taques é emblemática de tal forma de pretensão. Ao escrever Nobiliarquia Nobiliarquia paulistana, esforça-se em reforçar os elementos enobrecedores dos paulistas mais ilustres, construindo, dessa forma, uma narrativa nobilitadora.

Pretensão que pode ser verificada nas palavras de Afonso de Taunay, que ao defender os cronistas antigos, frei Gaspar da Madre de Deus e Pedro Taques, de críticas que os acusavam de escrever com "mania nobiliárquica" e sob o "prurido da vaidade", afirma que

irritam-se os críticos com a designação de 'nobre' atribuída a estes àquelas famílias, esquecendo-se, porém, de que, para os antigos povoadores, 'nobre' e 'fidalgo' não eram exatamente a mesma coisa. Enfurece-os o atributo 'princesa brasílica' referente às matriarcas paulistas, mulheres de João Ramalho e Antônio Rodrigues, filhas de vulgares caciques, alegam. ${ }^{426}$

Corroborando a defesa de Taunay, sabemos que havia em Portugal um rigoroso controle de acesso à aristocracia e, inclusive punições para quem ostentasse símbolos de distinção sem ter o direito. Nas Ordenações Filipinas, o título XCII do livro V intitula-se "Dos que tomão insignias de armas, e dom, ou appelidos, que lhes não pertencem”, sendo que os que usam título de nobreza sem direito e indevidamente "pagarão cem cruzados, ametade para que os accusar, e a outra metade para a nossa Camera" ${ }^{427}$.

Encontramos argumento favorável à interpretação de nobreza pretendida em um registro das Atas da Câmara de São Paulo de 22 de outubro de 1639. Tal passagem foi descrita por Taunay em 425 Carta LXXXIII. op. cit., vol. II.

426 Afonso d'E. Taunay. São Paulo nos primeiros anos e São Paulo no século XVI. São Paulo: Paz e Terra, 2003 , p. 386. 427 Ordenações Filipinas, liv. V, tít. XCII, item 6. 
sua História seiscentista da villa de São Paulo, porém, apontado por Edmundo Zenha como busca do colono pela distinção social ${ }^{428}$.

Taunay relata que em 22 de outubro de 1639 ,

perante s. Mercês compareceu o velho Antonio Alves, juiz dos selleiros. Declarou 'ser hu omen velho, e ter bens bastantes pera sustentar-se sem uzar do dito officio'. Assim, delle desistia, 'pera guozar das outras liberdades dos omes nobres', pois 'dele não queria uzar em tempo algu'. Assim, passou o 'mequaniquo' á categoria de 'omen nobre', podendo servir os cargos da Republica, sem infringir as leis de S. Majestade. ${ }^{429}$

Com isso, defendemos que a compreensão do poder local na colônia, principalmente no que se refere às câmaras municipais, passa pela abordagem das formas de poder e de sua aplicação. A interpretação patrimonialista dos cargos administrativos, junto com sua concepção honorífica e, portanto, de distinção social, permitem um melhor esboço sobre a questão.

\section{2 - Consequências do poder local na urbanização de São Paulo}

A vila de São Paulo foi instalada em uma colina tabular de nível intermediário, com altitude média variando entre 745 e 750 metros, delimitada pelo córrego Anhangabaú e rio Tamanduateí, afluente esquerdo do rio Tietêt ${ }^{430}$.

A escolha desse sítio se deu pela proximidade com o colégio jesuítico, fundado em 1554 e que garantiria estabilidade ao povoado. Nas palavras de Frei Gaspar da Madre de Deus, aos jesuítas, "não lhes agradando a povoação de Santo André, nem a aldeia de Piratininga, escolheram um local eminente, entre os Rios Tamandoatei e o ribeiro Anhangabau, três léguas afastado da dita

428 Edmundo Zenha. op. cit., p. 94-95.

429 Afonso d'E. Taunay. História seiscentista da villa de São Paulo. São Paulo: Ideal, 1926, vol. IV, p. 325.

430 Aziz Ab'Sáber. Geomorfologia do sítio urbano de São Paulo. São Paulo: Ateliê, 2007, p. 107. 
povoação"431.

Em 1560 o governador geral Mem de Sá extinguiu a vila de Santo André e transferiu seu pelourinho para a frente do Colégio dos Jesuítas ${ }^{432}$. Essa mudança foi justificada por Frei Gaspar devido ao prestígio dos inacianos, seja com o governador, seja com os índios, que eram atraídos para o empreendimento.

Contudo, devemos procurar compreender melhor o contexto do período inicial da ocupação do planalto. Afonso de Taunay apresenta as primeiras décadas da vila de São Paulo como marcadas por constantes ameaças decorrentes de ataques de grupos indígenas hostis aos portugueses. E relata que,

quando os índios começaram a fazer correrias nos arredores da cidade, vários moradores do campo pediram terras no recinto protegido, que era exíguo. Assim sucedeu a João de Sant'Anna, em 1592, candidato a 'cinco braças craveiras com o quintal necessário, por ser muito necessário recolher-se os moradores à Vila por respeito de estar em guerra ${ }^{433}$.

Longe de concluir a questão, podemos inferir que o contexto de conflitos no planalto influenciou a transferência do município para o sítio em que se encontra São Paulo. Foi transposta uma vila situada nas bordas do campo, tal como ocorria com Santo André, em uma região plana e, portanto, mais vulnerável a ataques, para um núcleo em uma posição mais estratégica.

O sítio urbano inicial de São Paulo permitiu o controle de vasta área de campos, correspondentes aos terraços fluviais das bacias do Tamanduateí e Tietêt ${ }^{434}$.

O núcleo urbano inicial da vila de São Paulo foi instalado em uma acrópole, sendo que essa topografia influenciou fortemente o processo de urbanização.

431 Frei Gaspar da Madre de Deus. Memórias para a história da capitania de São Vicente. São Paulo: Comissão do IV Centenário, 1954, p. 123.

432 Frei Gaspar da Madre de Deus. op. cit., p. 125.

433 Afonso de Taunay. São Paulo nos primeiros anos e São Paulo no século XVI. São Paulo: Paz e Terra, 2003, p. 107108.

434 Aziz Ab'Sáber. op. cit., p. 137. 


\section{Mapa 1 - Topografia da área central de São Paulo}
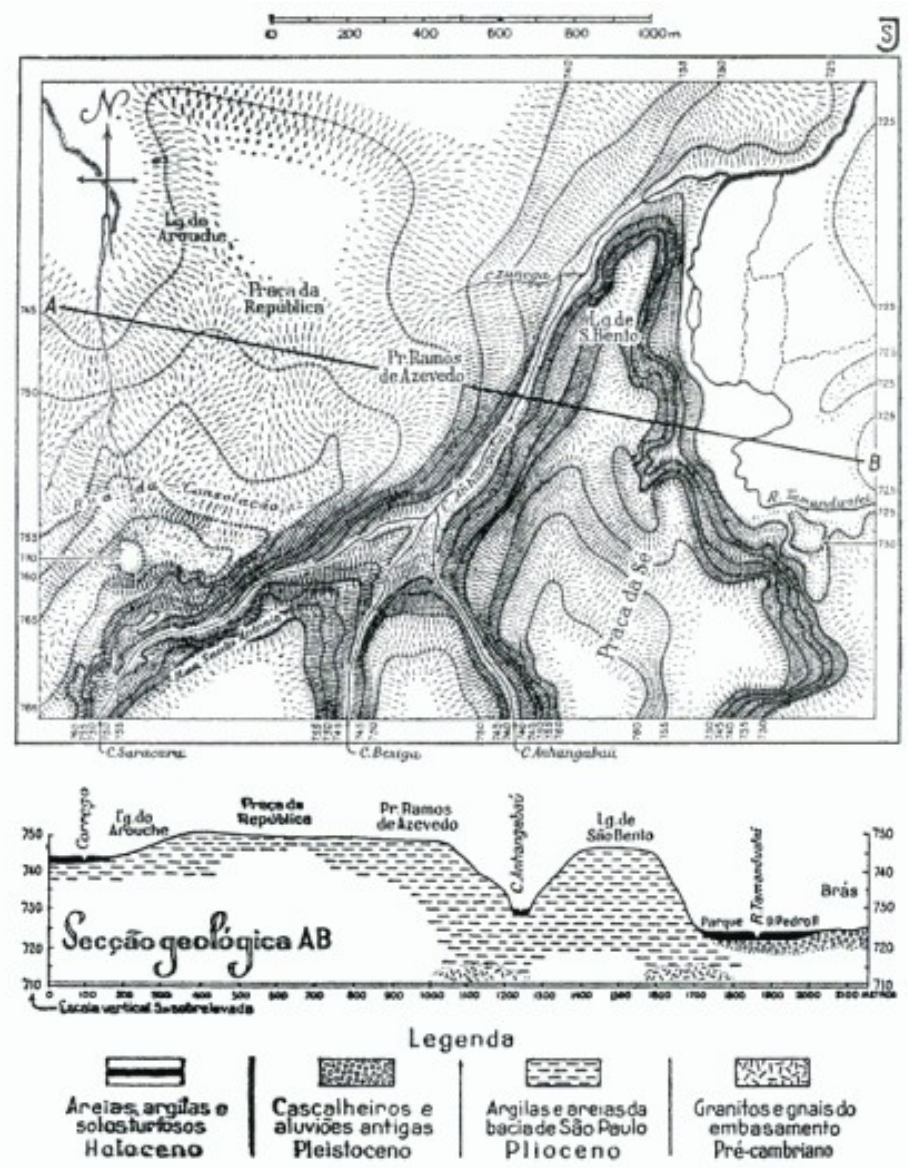

Fonte: Aziz Ab'Sáber. Geomorfologia do sítio urbano de São Paulo. São Paulo: Ateliê, 2007, p. 172. 


\section{Rossio e Terras de Índios}

Ao invés de condicionar o traçado irregular das ruas apenas como consequência da topografia do sítio, iremos refletir melhor sobre os espaços na vila de São Paulo.

Conforme definimos no capítulo 1.1, as câmaras dos municípios detinham uma área que compreendia seu patrimônio nomeada de rossio, para concessões e ocupação de moradores.

Nestor Goulart Reis afirma que "o rossio era uma parcela do termo demarcada junto aos núcleos urbanos, utilizada para atender ao crescimento das formações urbanas, para pastagens de animais de uso dos moradores e para o recolhimento de lenha por parte das pessoas de condição mais humilde" ${ }^{435}$.

Murillo Marx, por sua vez, define rossio como patrimônio do município e “mantinha-se como área de proveito comum nem sempre respeitada e com abusos que parecem crescer, pela leitura dos documentos, à medida que cresciam e se adensavam os aglomerados. Ia sendo transformada em novas datas e novas ruas, e, dessa forma, atendendo à necessidade de chão, privada e coletiva" ${ }^{436}$.

A reflexão dos dois autores permite conceber o rossio como uma reserva de terras para o crescimento do núcleo urbano, quer por meio de concessões e aforamentos quer pela construção de novos arruamentos para servir às novas propriedades.

Portanto, o estudo das utilizações do rossio e suas consequências são fundamentais para a reflexão sobre o traçado urbano das vilas colonias. Mais do que apenas influenciadas pela topografia, as câmaras das vilas concederam propriedades e, subsequentemente, acessos a essas, sem obedecer a uma planificação moderna. As concessões seguem tanto as necessidades políticas de conceder terras, como as econômicas de expandir propriedades e as geopolíticas quando de ataques

435 Nestor Goulart Reis Filho. Contribuição ao estudo da evolução urbana no Brasil. São Paulo: Pioneira, 1968, p. 112.

436 Murillo Marx. Nosso chão: do sagrado ao profano. São Paulo: EdUSP, 1989, p. 76. 
de índios.

Estabelecidos esses parâmetros, devemos, a partir desses, definir melhor o rossio e ponderar sobre suas principais características.

Apesar do rossio ser patrimônio do município desde sua origem e a Câmara ter doado e aforado terras durante séculos, até 1769 não havia demarcação precisa desse patrimônio. Somente em 30 de julho desse ano é que se localiza o "registro de huma ordem que o Illmo e Exmo Snr Gnal desta Capitania escreveo a este Camera a Serca de se medir mea Legoa de terra para Cada Lado para Rocio desta Cidade, fazendo pião nesta mesma Cidade como abaix Se decala \&a." ${ }^{437}$.

A demarcação foi realizada, conforme indica Raquel Glezer, por João da Silva Machado, escrivão da Câmara; Domingos de Cubas, alcaide e Antonio de Silva Lopes, arruador e medidor do Concelho ${ }^{438}$.

A área de rossio demarcada corresponde

... para a parte da Capella e Bairro de Nossa Senhora da Penha se meio mea Legoa... athe o alto da Chacra do defunto Manoel Luiz Costa em huma chapadinha ao pe do mato escuro em que Se fez um Sinal para Se asentar padrão e para a parte da Capella de Nossa Senhora da Lus e Bairro de Santa Anna Se medio outra mea Legoa... adiante da ponte grande do Ryo thiete no aterro que vay para Santa Anna adonde Se por Sinal para tambem Se aSentar padram e para a parte do ancieto e Aldea dos pinheiros Se medio outra mea Legoa... no alto da emcruzilhada desendo para o Citio de Margaride de Oliveira adonde ficou e Se aSentou Sinal para Se aSentar o padram e para a parte do Caminho da villa de Santos Se medio outra mea Legoa... athe o Citio de Joze da Silva Brito Junto ao Corrigo chamado o pi ranga adonde da mesma forma ficou hum Sinal para Se aSentar padram; e todo o Roçio assim declarado foy medido... ${ }^{439}$

Temos, portanto, a área delimitada do rossio, que foi oficialmente demarcada em fins do

437 Carta XXI. Cartas de datas de terra de São Paulo. São Paulo: Departamento de Cultura, 1937, vol. V. 438 Raquel Glezer. Chão de terra e outros estudos sobre São Paulo. São Paulo: Alameda, 2007, p. 97.

439 Carta XXII. Cartas de datas de terra de São Paulo. São Paulo: Departamento de Cultura, 1937, vol. V. 
século XVIII. No entanto, a Câmara doava, desde o início, terras patrimoniais, tanto dentro da delimitação de meia légua quanto fora.

Observamos que a denominação "Marco" referindo-se ao marco de meia légua decorrente da delimitação do rossio permaneceu por muitos anos na região do Brás e Belenzinho ${ }^{440}$.

Verificamos, no entanto, que inúmeras concessões da Câmara ocorreram fora da área da meia légua. O exemplo mais evidente é da solicitação de Pantalião Pedroso Baião, de 1688. Apresenta-se como morador na vila de São Paulo e solicita terras "no termo desta villa donde chamão orCangá onde teve Diogo de Orbos hum Sitio comeSando dahy correndo pello Ryo Jhequabucu aRiba athe o Ribejro que Serve a aguada a Simão Lopes Fernandes" ${ }^{441}$.

Isso ocorreu, provavelmente, em decorrência da ausência de um referencial mais seguro, como o estabelecido em 1769. Taunay nos conta que, nos últimos anos do século XVI "pediram os vereadores que o raio de concessão fosse 'de cinco tiros de besta, ao derredor da vila'" ${ }^{442}$.

Dessa forma, ficamos impossibilitados de traçar uma área determinada em que ocorreram as concessões e aforamentos por parte da Câmara Municipal. Todavia, podemos estabelecer regiões em que houve, prioritariamente as concessões, verificando como essas ações influenciaram o ordenamento urbano de São Paulo.

Vemos na tabela 10 do capítulo anterior que 79\% das concessões entre 1560 e 1765 ocorreram no rossio da vila, 7\%, ou seja, 17 casos, ocorreram nas terras da aldeia de São Miguel, enquanto que as aldeias de Barueri e de N. Senhora da Conceição, contabilizaram 2,1\% e 1,2\%, respectivamente. A denominação genérica "terras de índios", que pode contemplar qualquer aldeamento, foi apontada em $9,9 \%$ das datas de terra.

A ocupação das terras indígenas foi fenômeno de longa data. Sylvio Bomtempi afirma, em relação às terras da aldeia de São Miguel, que aquelas “eram muito procuradas e para a sua direção

440 Margarida Maria de Andrade. Bairros do além-Tamanduateí: o imigrante e a fábrica no Brás, Mooca e Belenzinho. São Paulo, 1991. Tese de doutorado (Geografia Humana) - Faculdade de Filosofia, Letras e Ciências Humanas, Universidade de São Paulo, p. 27-29.

441 Carta XXIX. Cartas de datas de terra de São Paulo. São Paulo: Departamento de Cultura, 1937, vol.III. 442 Afonso Taunay. op. cit., p. 106. 
voltaram-se muitos colonos, atraídos em 1612 pelo prosperar de Geraldo Correia Sardinha, então empenhado na exploração das minas de ouro descobertas nas proximidades do ribeirão Maquirobu, atual Baquirivu" ${ }^{443}$.

As terras dos índios não pertenciam à Câmara e estando fora de sua jurisdição não poderia ela conceder terras. A Câmara, nas palavras de Bomtempi,

limitou-se ao silêncio, forma tácita de cumplicidade. Sabiam os camaristas da intangibilidade da sesmaria e além disso não podiam ignorar que não a abrangia o foral da vila. Deste modo, efetuou-se a fixação dos primeiros brancos nas terras por via do apossamento puro e simples, sem título ou outras quaisquer formalidades, deste modo que logo se transformaram partes das sesmarias dos índios em roças e pastos. $^{444}$

A situação da posse das terras indígenas por colonos levou a que "por volta de 1660 a Câmara passasse a invocar uma provisão de Diogo Luís de Oliveira, governador-geral de 1627 a 1635, pela qual concedia autorização de se repartirem pelos moradores as terras dos índios, desde que estes não fossem prejudicados" ${ }^{445}$.

A provisão acima, mais do que permitir a ocupação das terras dos índios, permitiu a regularização de uma situação de facto, possibilitando, a partir disso, uma intensificação da ocupação da área.

No entanto, a mais importante ação que desencadeou a plena ocupação da aldeia de São Miguel por colonos se deu em 8 de maio de 1679, quando o desembargador e ouvidor-geral João da Rocha Pitta

deixou alguma determinação para emenda do que reputava contrário à justiça e aos diplomas legais então em vigência. Tomou conhecimento da grave questão da

443 Sylvio Bomtempi. O bairro de São Miguel Paulista. São Paulo: DPH, 1970, p. 49.

444 Sylvio Bomtempi. op. cit., p. 50.

445 Sylvio Bomtempi. op. cit., p. 64. 
invasão das terras dos índios e dos direitos que a Câmara vinha firmando sobre elas. E neste passo deixou, em capítulos de correição, disposições que viriam causar a intensificação do povoamento de São Miguel. Reconheceu o direito da Câmara de estender o seu poder a São Miguel, o que já vinha sendo feito por atos de força. Agora os oficiais da Câmara incluíam no rol de sua competência o poder de dar às terras dos índios a destinação que bem entendessem, sem embargo de terem sido doadas aos índios, então, há um século, com finalidades expressas e minuciosamente definidas. ${ }^{446}$

Com isso, temos um panorama, já no início do século XVII, de duas regiões que concentravam a ocupação de terras municipais. Temos o núcleo inicial da vila, em acrópole, com urbanização marcada pela construção de casas, em parte decorrente das fugas de moradores do campo por conta dos ataques indígenas do final do século XVI e início do XVII. A outra região foi ocupada a partir das terras da aldeia de São Miguel, o que permitiu uma expansão de São Paulo para o leste. Encerrados os conflitos, pode a vila expandir-se pelos outrora perigosos campos. O aumento significativo da propriedade da Câmara, com a incorporação das sesmarias de 6 léguas pertencentes aos índios ${ }^{447}$, possibilitou uma maior distribuição de terras, evitando conflitos em decorrência da dificuldade de acesso a ela. Esse tema será desenvolvido adiante. Iremos, agora, fazer uma reflexão sobre o traçado das ruas em São Paulo.

\section{Traçado das ruas}

A discussão sobre o traçado pode ser dividida em duas grandes categorias. A primeira defende que a urbanização da colônia não seguiu padrões racionais, enquanto que para a segunda houve racionalidade no ordenamento urbano.

446 Sylvio Bomtempi. op. cit., p. 66-67.

447 Em 1580, os índios de Pinheiros e de Ururai, depois denominada aldeia de S. Miguel, receberam "sesmaria de 6 léguas em quadra começando onde se acabam as terras que se deram a João Ramalho e Antonio Macedo onde eram onde chamam Jaguapore...ba”. Carta III. Carta de datas de terra de São Paulo. São Paulo: Departamento de Cultura, 1937, vol. I. 
A primeira categoria, cujos principais autores são Afonso de Taunay e Sérgio Buarque de Holanda, advoga que as vilas e cidades coloniais foram obra do acaso, sem que houvesse preocupação com a organização espacial.

Taunay afirma que "não é certamente também a uma vila do século XVI que se deverá recorrer para encontrar bons exemplos a respeito de normas arquitetônicas e de preceitos de urbanismo, sobretudo no mundo lusitano, no Brasil e na situação em que se achava São Paulo"448. Relativiza "o desconhecimento completo da estética e do conforto" 449 defendendo que "se nas maiores cidades do globo ignoravam-se as mais elementares regras de higiene, se a sua rede de ruas formava a mais emaranhada trama de escuras vielas e sombrios becos, que esperar do plano sobre a qual se alinhavam as escassas habitações de Piratininga?"450.

Não obstante a defesa acima citada, o autor não nega a irregularidade do traçado e ausência de quaisquer preocupações com a organização urbana. Sérgio Buarque de Holanda, contudo, ao comparar as cidades portuguesas e castelhanas, compromete seriamente os argumentos de Taunay,

Ao tratar da cidade castelhana, Sérgio Buarque ressalta que "o próprio traçado dos centros urbanos na América Espanhola denuncia o esforço determinado de vencer e retificar a fantasia caprichosa da paisagem agreste: é um ato definido da vontade humana. As ruas não se deixam modelar pela sinuosidade e pelas asperezas do solo; impõem-lhes antes o acento voluntário da linha reta" ${ }^{451}$.

Em oposição, na cidade portuguesa, "a rotina e não a razão abstrata foi o princípio que norteou os portugueses, nesta como em tantas outras expressões de sua atividade colonizadora. Preferiam agir por experiências sucessivas, nem sempre coordenadas umas às outras, a traçar de antemão um plano para segui-lo até o fim" ${ }^{452}$.

Conclui que "a cidade que os portugueses construíram na América não é produto mental,

448 Afonso de Taunay. op. cit., p. 112.

449 Afonso de Taunay. op. cit., p. 112.

450 Afonso de Taunay. op. cit., p. 112.

451 Sérgio Buarque de Holanda. Raízes do Brasil. São Paulo: Companhia das Letras, 2003, p. 96.

452 Sérgio Buarque de Holanda. op. cit., p. 109. 
não chegar a contradizer o quadro da natureza, e sua silhueta se enlaça na linha da paisagem. Nenhum rigor, nenhum método, nenhuma previdência, sempre esse significativo abandono que exprime a palavra 'desleixo'" 453 .

Nestor Goulart Reis Filho, representante da segunda categoria estabelecida por Amílcar Torrão Filho, afirma que houve padrões de racionalidade e regularidade na organização urbana na colônia. Afirma que "a época do descobrimento do Brasil, as tendências geometrizantes estavam sendo adotadas em quase todas as experiências urbanísticas europeias e seria por seus princípios que se orientaria o urbanismo colonial posto em prática com a expansão europeia" ${ }^{454}$.

Mesmo em sítios com topografia menos favorável, como nas vilas em acrópole, Nestor Goulart defende que houve racionalidade no traçado urbano. Para esses

núcleos menos, mais antigos, [que] instalavam-se em sua maior parte, em sítios acidentados, no topo de colinas. Seus traçados apresentavam, então, no conjunto, características de acentuada irregularidade. As ruas adaptaram-se às condições topográficas mais favoráveis, e tendiam a se organizar como ligações entre os pontos de maior importância na vila desses núcleos, sem intenção de ordenamento geométrico. ${ }^{455}$

Em publicação de 2004, Nestor Goulart desenvolve o conceito de racionalidade e aplica-o para a vila de São Paulo em seus primeiros séculos. Procura uma regularidade no traçado urbano e, para tanto, referencia-se nos muros que protegiam o núcleo de ataques indígenas.

Segundo o autor, "os muros da vila deveriam necessariamente correr pela parte interna desses cursos d'água ou deixar que nos pontos mais baixos ficassem as portas e sob essas deixassem passar as enxurradas" 456 . E, a partir da definição desses muros “é possível compreender os limites da vila e identificar as casas e ruas que de início acompanhavam o seu limitado tecido urbano" 457 .

453 Sérgio Buarque de Holanda. op. cit., p. 110.

454 Nestor Goulart Reis Filho. op. cit., p. 128.

455 Nestor Goulart Reis Filho. op. cit., p. 130.

456 Nestor Goulart Reis Filho. São Paulo vila cidade metrópole. São Paulo: Via das Artes, 2004, p. 22.

457 Nestor Goulart Reis Filho. op. cit., p. 27. 
Nestor Goulart visualiza no traçado inicial de São Paulo dois padrões: um irregular e outro mais regular. O primeiro corresponde aos primeiros arruamentos, ainda dentro dos muros primitivos. O segundo, seria o das ruas abertas após a demolição dessas estruturas. Afirma que

quando observamos as plantas mais antigas de São Paulo, de 1760/80, de 1800 e de 1810, podemos constatar que a partir do núcleo inicial, que havia sido cercado pelos muros, saem diversas ruas retas (rua do quartel, da esperança, de S. Gonçalo, Quintino Bocaiúva, direita, São Bento, das flores e tabatinguera) em mais em uma direção. Essa mudança de orientação não pode passar sem registro. No começo do século XVII - portanto em tempos de D. Francisco e de D. Luís - essas décadas seguintes, foi deixado de lado a informalidade dos primeiros tempos, estabelecendo-se um pouco de disciplina urbanística. Dentro de suas limitações, eram novos tempos. ${ }^{458}$

Murillo Marx, por sua vez, aborda o traçado urbano das cidades coloniais seguindo outra lógica, que ultrapassa a discussão sobre regularidade e irregularidade. Apresenta que "a maneira como se deu e formalizou a união da Mitra com a Coroa torna-se expressa em muitas das peculiaridades da conformação urbanística de nossos aglomerados urbanos e, particularmente, nas características de seus espaços públicos" ${ }^{459}$.

Dessa forma, é importante ressaltar que, segundo o autor citado, a união entre Igreja e Estado e a influência social e política dessa, foi fundamental na organização espacial das cidades coloniais. Tal interpretação nos leva a compreender a ausência de grandes vazios no tecido urbano. As praças, ao contrário da América espanhola, devem sua existência, sobretudo, aos adros das igrejas $^{460}$.

Esse espaço localizado em frente às igrejas visava conferir destaque à construção e foi estabelecido por legislação eclesiástica. Assim, compreende-se "serem os adros suas únicas praças,

458 Nestor Goulart Reis Filho. op. cit., p. 40.

459 Murillo Marx. Nosso chão: do sagrado ao profano. São Paulo: EdUSP, 1989, p. 21.

460 Murillo Marx. Cidade brasileira. São Paulo: Melhoramentos, 1980, p. 50. 
ou melhor, largos, ou alargamento de suas ruas" ${ }^{\prime 461}$.

Define Murillo Marx que "durante todo o período colonial, as áreas coletivas estavam direta ou indiretamente submetidas também às normas do direito canônico"462. Em decorrência dessa situação, os espaços públicos estavam intimamente ligados à religião, influenciando as relações de sociabilidade. Com isso, compreendemos a quantidade de igrejas, as ruas que eram o trajeto das

procissões e que ligavam os diversos templos. É válida a sua observação que "os jardins eram raros na cidade colonial brasileira. Resumiam-se a parcelas das grandes propriedades religiosas e dos quintais das residências" ${ }^{63}$. E que "o jardim público aparece entre nós, como reflexo do Iluminismo e da expansão dos maiores centros urbanos, no fim do período colonial"464.

\section{Ordenamento político}

A interpretação de Marx sobre as influências religiosas no ordenamento urbano de São Paulo possibilitou lançar nova luz à questão. Tal apontamento nos permite levantar a questão em um caminho próximo, mas seguindo uma abordagem diferente.

Buscamos verificar se o poder político, tal como caracterizamos no capítulo 3.1, influenciou o traçado urbano e a utilização espacial da vila e cidade de São Paulo. Reiteramos que a posição de destaque das construções religiosas, seus adros e caminhos foram fundamentais para a estruturação urbana. Queremos, contudo, contribuir para a discussão ao tratar principalmente dos terrenos com usos não religiosos, que eram usados como moradia e comércio, por exemplo.

A concepção clássica de rossio, elaborada por Taunay, define que "as concessões de chãos [eram feitas] facilmente, como era natural num lugar onde tanta terra havia e tão pouca gente" ${ }^{\$ 65}$ é somada à ideia de Nestor Goulart de uso comum e de aproveitamento por pessoas de condições

461 Murillo Marx. Nosso chão: do sagrado ao profano. São Paulo: EdUSP, 1989, p. 112.

462 Murillo Marx. op. cit., p. 199.

463 Murillo Marx. Cidade brasileira. São Paulo: Melhoramentos, 1980, p. 57.

464 Murillo Marx. op. cit., p. 68.

465 Afonso de Taunay. op. cit., p. 108. 
mais humildes ${ }^{466}$.

No entanto, ao analisar sistematicamente as concessões de terra pela municipalidade e cruzando esses dados com os nomes de oficiais da Câmara e seus parentes verificamos uma situação distinta. Conforme abordamos no capítulo 3.1, as terras do rossio, patrimônio da Câmara, foram consideradas como patrimônio dos membros dessa e foram repartidas entre os oficiais e seus familiares.

Logo, não havia, ao contrário do que a historiografia aponta, acesso facilitado às terras urbanas nem fixação de pessoas humildes no núcleo da vila pelo menos, pela documentação. O que vemos é uma concepção patrimonialista da função camarária, o que seria, em grande parte, responsável pela concentração das propriedades nas mãos de um pequeno grupo político.

Não estamos afirmando que havia restrição absoluta ao acesso à terra e que quem não pertencesse à elite política ou fosse vinculado à ela não teria onde lavrar ou habitar. Estamos tratando de título de propriedade, isto é, do reconhecimento de uma autoridade, nesse caso o da Câmara Municipal que o proprietário possui a terra. O que quer dizer que havia a posse, embora essa não tivesse nenhuma segurança jurídica e somente poderia ocorrer em áreas mais afastadas do núcleo urbano, longe dos interesses de quem detinha o mecanismo oficial de concessão de propriedades.

Esses apossamentos, devido à sua característica intrínseca, não foram documentados por não haver registros desses. Encontramos referências a esses casos quando da ocupação de terras indígenas na aldeia de São Miguel e de casos de "regularização" de terras, isto é, de pessoas que, com vínculo direto ou indireto com o poder local, podiam oficializar a propriedade de suas terras até então apossadas.

Esse é o caso da solicitação de 1728 de Antonio Siqueira, o moço, que argumenta que "elle estaa de poSse há des annos de Canto e SinCoenta braÇas de terra na paragem chamada Tambem 
destricto do bairro de Sam Miguel"467. Em 1686, Izabel Pompeia requere a propriedade de terras à Câmara. Para tanto, alega que é

moradora no termo e limite da villa de Parnaiba da Senhora Sant'Anna que por essas licenças e doações que com esta offerece há cincoenta e tantos annos que o pae della supplicante Manuel de Goés Raposo esta de posse das ditas terras e por esta razão prefere ella supplicante que ninguem para as aforar pois tem feito casas e bemfeitorias de paga dízimos pelo que pede a vossas mercês lhe façam mercê aforar as terras que consta por estas datas e licenças. ${ }^{468}$

Diante do panorama de relações entre poder político e concessão de terra, propomos iniciar uma discussão sobre suas consequências para a formatação espacial do núcleo urbano de São Paulo.

Inicialmente, para buscar analisar a espacialidade do núcleo, devemos recorrer às representações de mapas. Porém, os mapas de São Paulo são extremamente raros e datam principalmente do século XIX. Assim, o primeiro registro das ruas da cidade são creditados a Rufino Felizardo e Costa, na "Planta da Cidade de S. Paulo" de $1810^{469}$.

Nestor Goulart, no entanto, apresenta uma planta, denominada "Planta da Restauração". Afirma que "o traçado geral pode corresponder aos tempos do Morgado de Mateus - ou mesmo ser anterior - pois ali não encontramos sinais da Rua Nova de S. Bento, hoje Florêncio de Abreu, da Rua Nova de S. João, hoje Líbero Badaró, e da Rua de São João, abertas respectivamente em 1782, 1786/87 e 1786/88"470. Conclui que "devemos acreditar que o traçado geral da 'Planta da Restauração' - como preferimos chamá-la - deve corresponder ao período 1765/1780״ "471.

No entanto, Nestor Goulart aponta que "a planta recebeu acréscimos posteriores em mais de

467 Carta LXIV. Carta de datas de terra de São Paulo. São Paulo: Departamento de Cultura, 1937, vol. IV. 468 Carta LXXXIII. Carta de datas de terra de São Paulo. São Paulo: Departamento de Cultura, 1937, vol. III. 469 Nestor Goulart Reis Filho. op. cit., p. 85. 470 Nestor Goulart Reis Filho. op. cit., p. 68. 471 Nestor Goulart Reis Filho. op. cit., p. 68. 


\section{Mapa 2 - Planta da Restauração (1765)}

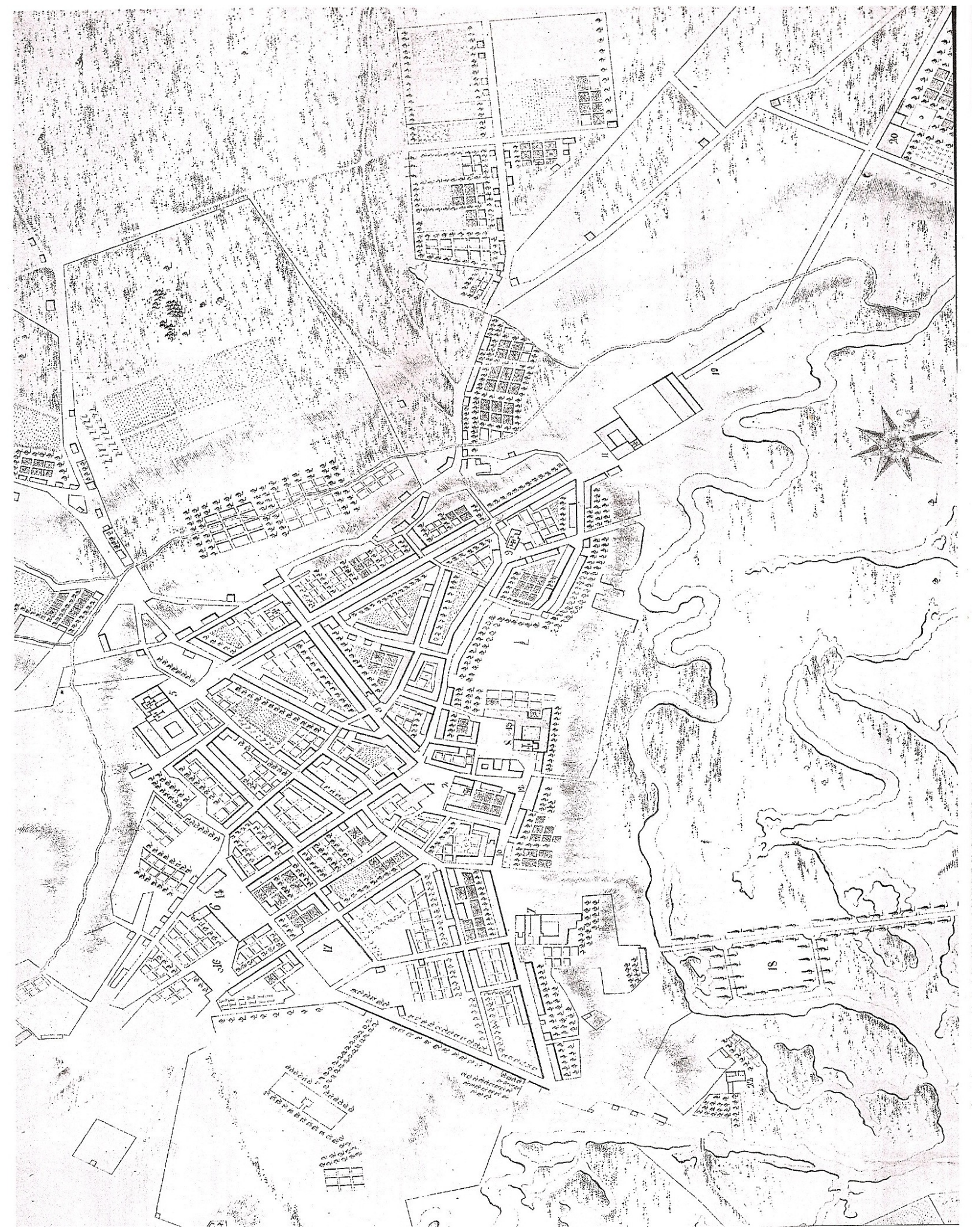

Fonte: Nestor Goulart Reis Filho. São Paulo vila cidade metrópole. São Paulo: Via das Artes, 2004, p. 66. 
um momento (inclusive depois de 1822), o que torna sua leitura mais difícil”472.

A partir dessa planta e levando em consideração a imprecisão de sua data e subsequentes alterações, optamos por não analisá-la em seus detalhes. Levar em conta pequenas informações desse documento poderia levar-nos certamente a conclusões equivocadas.

Procuramos observar nesse desenho uma configuração mais geral do traçado das ruas, bem como do aproveitamento dos lotes urbanos. Observando a planta, notamos que o núcleo concentrase, principalmente, no sítio urbano inicial, na colina delimitada pelo rio Tamanduateí e o ribeirão Anhangabaú.

Observamos a quantidade de templos religiosos, com seus respectivos adros. Notamos também que as aberturas dentro do tecido urbano correspondem aos largos em frente às igrejas, como aponta Murillo Marx.

As ruas seguem um ordenamento visual não muito evidente à primeira vista, pois segue a lógica de ligação de templos. Caminhos para demais localidades, como para a aldeia de Pinheiros, para a igreja da Penha ou o caminho para Santos, determinam também alguns dos arruamentos.

A relação entre poder político local e concessão de terras ajuda-nos a compreender a estrutura do lote urbano. Se houvesse distribuição de terras a quem necessitasse, os lotes tenderiam a ser mais compactos ou a área urbana um pouco maior.

As ruas eram delimitadas pelas construções, que ocupavam majoritariamente a testada do terreno. As áreas internas do lote eram ocupadas por quintais e pomares ${ }^{473}$.

A ausência de jardins ou outras áreas de sociabilidade é perceptível. Excetuando-se a convivência religiosa nos adros e através das procissões, não havia espaço de encontro no tecido urbano.

Em uma sociedade em que não havia delimitação das esferas pública e privada em consequência da concepção patrimonialista dos cargos púbicos, tal como aponta Max Weber, 
encontramos o aproveitamento máximo do espaço. Esse aproveitamento se deu pela apropriação e cercamento das propriedades, procurando conceder ao máximo as áreas do rossio a particulares.

Do aproveitamento máximo do terreno foram poupados somente os adros da igreja devido ao respeito às normas eclesiásticas.

O adensamento da vila, com aproveitamento máximo das áreas do sítio urbano, pode ser um reflexo da concepção patrimonialista da distribuição das terras no rossio. A concessão de terras se deu mais por fatores políticos do que pela necessidade de produção e de ocupação das terras. O possuir terras urbanas tornou-se a efetivação da distinção social propiciada pelo pertencimento ao grupo que ocupava cargos na Câmara Municipal.

\section{3 - A criação de vilas no planalto serra-acima}

\section{Introdução}

Edmundo Zenha indica que o modelo de poder local aplicado nas colônias através das câmaras municipais foi uma extensão do praticado em Portugal.

Contudo, devemos problematizar melhor o conceito de vila, pensando-o como estrutura administrativa. Muitas vezes, considera-se a data de ocupação de um sítio como sua fundação e a “elevação à vila" como uma etapa posterior.

Azevedo Marques, por exemplo, ao tratar da vila de Parnaíba, escreve que "fundada pelo paulista capitão André Fernandes, que aí edificou uma capela à invocação de Santa Ana pelos anos de 1580 e seguintes, e que para esse lugar atraiu a seus pais Manuel Fernandes Ramos, natural de Portugal e D. Suzana Dias, natural de São Paulo, filha de Lopo Dias e de Beatriz Dias" ${ }^{474}$.

Vemos no trecho acima que é privilegiado, pela narrativa tradicional, o momento de fixação

474 Manuel Eufrásio de Azevedo Marques. Apontamentos históricos, geográficos, biológicos, estatísticos e noticiosos da província de São Paulo. São Paulo: Martins, 1954, vol. II, p. 146. 
dos portugueses e descendentes em uma nova área e não o estabelecimento da vila, isto é, quando o povoado se torna uma estrutura político-administrativa.

Não iremos analisar o povoamento do planalto em sua dimensão demográfica. Além de fugir do escopo de nossa pesquisa, tal tarefa seria praticamente inviável. Maria Luiza Marcílio, ao analisar as fontes demográficas coloniais, afirma que "os nossos conhecimentos sobre a realidade demográfica do Brasil, durante os dois primeiros séculos - XVI e XVII -, são quase nulos”475.

Como o objetivo desse capítulo é analisar a relação do poder local com a criação de vilas, devemos focar nosso estudo na criação de núcleos administrativos, isto é, no estabelecimento de novos municípios no planalto.

Iremos, portanto, tratar da relação dos oficiais da Câmara da vila, e depois cidade, de São Paulo, com a criação de novos municípios e, para tanto, descreveremos, brevemente, o processo de formação desses novos núcleos.

A vila de Mogi, segundo Azevedo Marques, foi fundada por Braz Cubas a partir de

uma fazenda de cultura por achar-se o terreno compreendido em uma grande sesmaria que obteve em 1560, a qual começava embaixo da serra, em território pertencente ao município de Santos. De então em diante foram-se aí aglomerando moradores emigrados da vila de São Paulo, entre eles Braz Cardoso, natural de Portugal, e sua mulher Francisca da Costa, de São Paulo, aos quais se deve principalmente o incremento da população, que foi elevada à vila a 3 de setembro de 1611, pelo capitão-mor Gaspar Couqueiro.

A seguinte certidão, extraída do maço $4^{\circ}$ de Próprios Nacionais existentes no cartório da Tesouraria da Fazenda, confirma a primeira parte do que acabamos de dizer.

'Certifico eu Manoel Rodrigues de Alvarenga, tabellião do publico n'esta villa de Sant'Anna das Cruzes de Mogy-mirim, em como é verdade que no cartorio d'esta villa está o foral e a fundação d'ella, e que foi fundada por uma provisão do Sr. Luiz de Sousa seu governandor, e o capitão-mor Gaspar Couqueiro levantou pelourinho, aos tres dias do mez de Setembro de 1611, havendo dez annos que na

475 Maria Luíza Marcílio. São Paulo: povoamento e população. São Paulo: Pioneira, 1974, p. 59. 
dita terra estavam moradores, e no dia, mez e anno que se lhe levantou the assignalou por limite a paragem chamada Embiacica, que é uma legua que fica na fazenda dos reverendos padres de Nossa Senhora do Carmo, aqual foi de Lopo Dias, e da banda do mar outra tanta terra e do Parahyba outra tanta, e para o sertão outro tanto, o qual termo foi dado com o consentimento das camaras das villas de S. Paulo, Santos e S. Vicente; e o dito capitão-mor logo no dito dia constituio officiais e justiças para reger e governar a villa. E por ser mandado passei a presente pelos officiais da Camara aos tres dias de Outubro de 1672 Manoel Rodrigues de Alvarenga. ${ }^{476}$

A vila de Parnaíba

começou por arraial do município da vila de São Paulo de Piratininga, fundada pelo paulista capitão André Fernandes, que aí edificou uma capela à invocação de Santa Ana pelos anos de 1580 e seguintes, e que para esse lugar atraiu a seus pais Manuel Fernandes Ramos, natural de Portugal e D. Suzana Dias, como se vê do livro $3^{\circ}$ de sesmarias existente no cartório da Tesouraria de Fazenda de São Paulo, onde consta que a 26 de dezembro de 1610 fizera petição Melchior da Costa, já casado com a viúva de Manuel Fernandes Ramos, e obtivera do capitão-mor Gaspar Couqueiro uma sesmaria.

(...)

A povoação foi criada vila por provisão do conde de Monsanto, então donatário da Capitania de São Vicente, datada de 14 de novembro de $1625.4^{477}$

Taubaté “deve a sua fundação ao capitão Jacques Félix, que em 1636 com o propósito desta fundação, para ali passou-se com sua família e grande número de índios mansos e que concedeu as primeiras sesmarias. Foi criada vila por provisão de 5 de dezembro de 1650 sendo capitão-mor Dionísio da Costa, loco-tenente do donatário da Capitania de Itanhaém”478.

Azevedo Marques descreve que Jacareí "foi fundada em 1652 por Antonio Afonso e seus filhos Francisco Afonso, Bartholomeu Afonso, Estevão Afonso e Antonio Afonso, que de São 
Paulo, com suas familias e agregados, foram establecer-se junto ao rio referido [Parnaíba]. Foi elevada à vila em 1653 pelo donatário D. Diogo de Faro e Souza"479.

Jundiaí

teve origem pelos anos de 1615, por emigração que para aí fizeram Rafael de Oliveira e a viúva Petronilha Rodrigues Antunes, naturais de São Paulo, os quais, com suas respectivas famílias, tendo ficado criminosos, para fugirem à perseguição da justiça, internaram-se pelos sertões, assentando vivenda no lugar em que está hoje a povoação e edificando logo depois uma capela sob a invocação da Senhora do Desterro.

Foi criada vila pelo capitão-mor Manuel de Quevedo Vasconcelos, como locotenente e procurador do então donatário da Capitania de São Vicente, conde de Monsanto, a 14 de dezembro de 1655 , e elevada à cidade por lei provincial de 28 de março de $1865 .^{480}$

Para a vila de Itu, Azevedo Marques descreve que

esta povoação, fundada e, território outrora pertencente ao município de Parnaíba, pelo capitão Domingos Fernandes e seu genro Cristóvão Diniz, que ali erigiram uma capela em honra da Senhora da Candelária, pelos anos de 1610, foi criada capela curada em 1644, elevada à freguesia em 1653 e à vila pelo capitão-mor Gonçalo Couraça de Mesquita a 18 de abril de 1657. (...)

Este capitão Domingos Fernandes foi filho de Manuel Fernandes, natural de Portugal e de Suzana Dias, natural de São Paulo, filha de Lopo Dias, de Portugal, e de Beatriz Dias, filha de João Ramalho. ${ }^{481}$

Para a vila de Guaratinguetá,

de diversos documentos antigos, consta que fôra seu fundador o capitão Domingos

479 Manuel Eufrásio de Azevedo Marques. op. cit., vol. II, p. 8. 
Leme, paulista notável e possante, que para ali emigrou com sua familia e aderentes na primeira metade do século XVII, provavelmente já em busca de minas de ouro.

Segundo o genealogista Pedro Taques, foi elevada à vila a 13 de fevereiro de 1657, pelo capitão-mor Dionísio da Costa, loco-tenente do donatário da Capitania. ${ }^{482}$

Azevedo Marques, ao descrever os primeiros anos da vila de Sorocaba, inicia o relato em 1600 , quando

o governador-geral D. Francisco de Sousa (que faleceu em São Paulo em 1611) intentou fundar ali uma povoação e que chegou mesmo a estabelecê-la pelos anos decorridos de 1600 a 1610, com o fim de dar desenvolvimento à exploração das minas; mas sobrevindo-lhe a morte, não progrediu a referida povoação, antes decaiu rapidamente até extinguir-se; essa povoação chamou-se Itapeboçu.

Em 1654, o paulista Baltazar Fernandes e seus genros André de Zunega e Bartolomeu de Zunega (espanhóis) emigraram de Parnaíba, onde residiam, e estabelecendo-se com suas famílias na distância de três léguas do morro de Biraçoiaba, fundaram ali uma capela dedicada à Senhora da Ponte; data desta época a fundação da hoje cidade de Sorocaba.

A elevação da povoação à categoria de vila pelo governador geral Salvador Corrêa de Sá e Benevides, consta da seguinte provisão:

'Porquanto, D. Francisco de Sousa, meu antecessor, governador geral que foi d'esta repartição, mandou levantar pelourinho na dita villa de Nossa Senhora da Ponte de Sorocaba, e por me constar que o capitão Balthazar Fernandes, morador antigo d'estas Capitanias, se foi para aquelle districto com outros muitos moradores, e trataram de mudar o dito pelourinho para outro sitio mais acommodado, dentro do mesmo limite, d'onde tem sua povoação e numero de mais de 30 casaes, que, conforme as doações dos donatarios d'esta Capitania, lhes concedem o poderem formar villas, deixando-lhe de terreno de uma a outras de quatro léguas; e porque todas estas cousas concorram n'esta nova povoação, e assim m'o haverem representado, por esta petição, os moradores d'aquella povoação, que, mandando pelo ouvidor d'esta Capitania fazer informações jurídicas, constou de todo o referido; e porque entre as mais cousas que me

482 Manuel Eufrásio de Azevedo Marques. op. cit., vol. I, p. 306-307. 
pediram foi licença para elegerem officies da Camara na via costumada; hei por bem, em conformidade dos foraes, se faça a dita eleição com parecer de pessoas graves; pelo que hei por bem nomear os juizes: o dito Balthazar Fernandes e Paschoal Leite Paes, e para vereadores: André de Zunega, Claudio Furquim (estava um claro), e para procurador, Domingos Garcia, e para escrivão da Camara, Francisco Sanches, que servirão este ano de 1661, e nos tempos costumados farão as eleições pela via ordinária. Com que tudo assim ordeno por serviço de Sua Magestade, augmento das terras dos donatarios e conveniencias dos moradores; e outrossim mando que esta minha provisão se registre no livro da Camara que há de servir. Em firmeza do que lhe mandei passar a presente, sob meu signal e sêllo de minhas armas, a qual se cumprirá tão pontualmente como n'ella se contém, sem duvida nem interpretação alguma. Dada e passada n'esta villa de S. Paulo, aos tres dias do mez de Março de 1661, e se registrará onde pertencer. Thomé Veiga a fez por mandado do dito Sr. Salvador Corrêa de Sá e Benevides'.483

A última vila fundada antes de 1765, ano que limita a nossa pesquisa, foi Pindamonhangaba. Essa, segundo Azevedo Marques,

foi fundada pelo padre João de Farias Fialho, que nela edificou igreja e a dotou com patrimônio pelos fins do século XVII.

Foi elevada à vila ilegalmente pelo desembargador João Saraiva de Carvalho, mas confirmada dois ou três anos depois por provisão de 10 de julho de 1705.

Pedro Taques diz que também foram fundadores desta vila o alcaide-mor Braz Esteves Leme, seu irmão Antonio Bicudo Leme, seu filho Manuel da Costa Leme e dos genros João Corrêa de Magalhães e Pedro da Fonseca Magalhães, por isso que foram eles que alcançaram do rei D. João $\mathrm{V}$ aprovação do ato ilegal do ouvidor Saraiva, apesar da oposição que faziam os moradores de Taubaté. ${ }^{484}$

Ao observarmos a descrição do processo de povoamento do planalto e a fundação das nove vilas serra-acima, notamos algumas semelhanças no processo.

483 Manuel Eufrásio de Azevedo Marques. op. cit., vol. II, p. 273-274.

484 Manuel Eufrásio de Azevedo Marques. op. cit., vol. II, p. 169. 
Mapa 3 - Vilas fundadas no planalto (1560-1765)
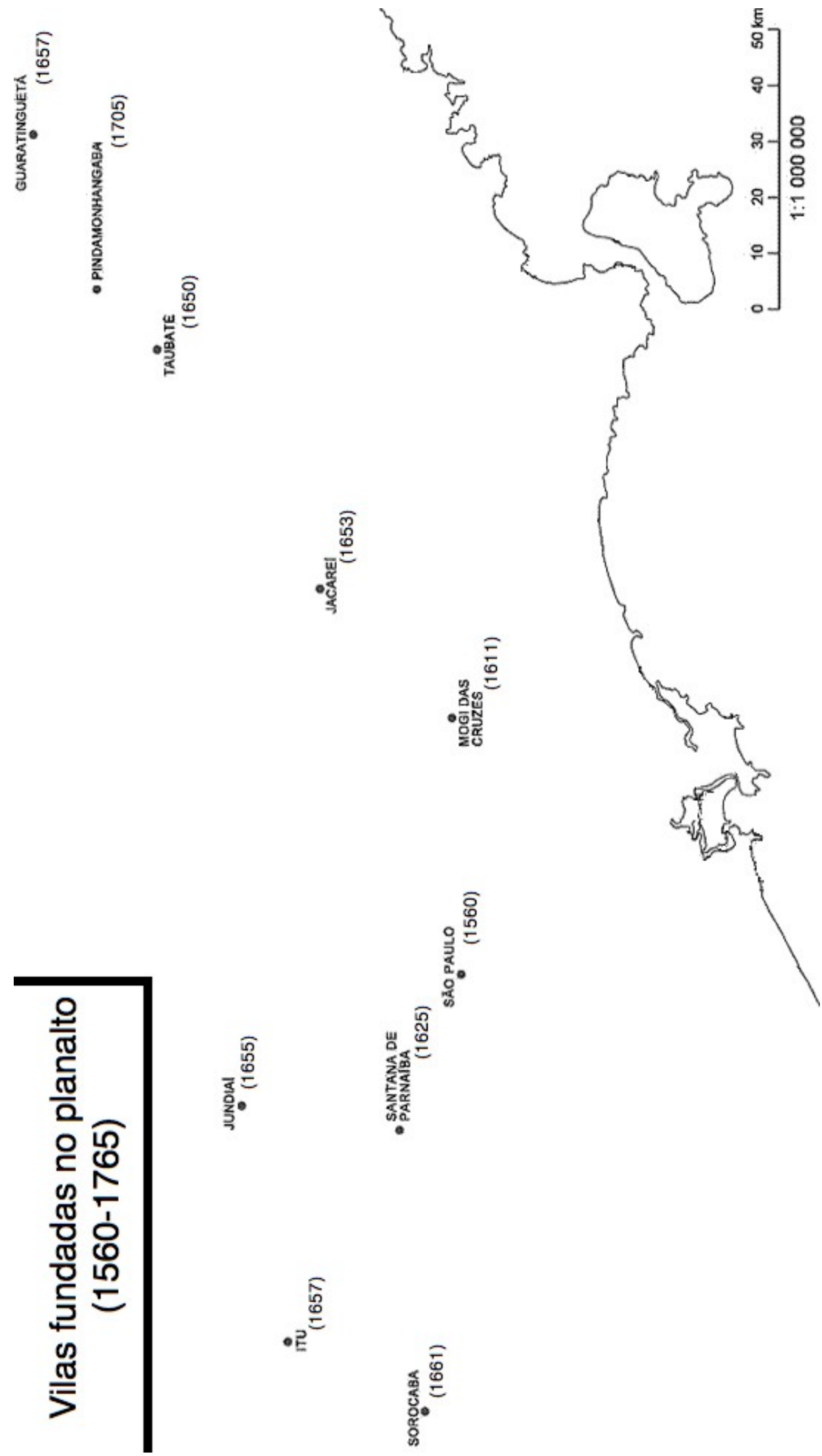

Fonte: Instituto Geográfico e Cartográfico de São Paulo e Azevedo Marques.op. cit. 
As vilas foram, em sua maioria, fundadas a partir do município de São Paulo. Excetuam-se as vilas de Itu e Sorocaba, fundadas a partir de Parnaíba, e de Pindamonhangaba, surgida de Taubaté. Dessa forma, podemos traçar um esquema para a fundação de vilas no planalto.

Observamos ainda que quase todas as vilas foram fundadas no século XVII e somente uma no início do século XVIII. Tal situação somente foi possível graças ao fim dos conflitos com os grupos indígenas, que marcaram as primeiras décadas de ocupação portuguesa no planalto.

Com o fim desses conflitos, notamos uma expansão da ocupação, primeiramente com a fundação de Mogi a leste, em 1611, e de Parnaíba a oeste, em 1625, funcionando como cabeça-deponte para a ocupação do sertão.

Antes de iniciar uma reflexão sobre as consequências do poder local na vila de São Paulo e as relações com a criação de vilas no planalto, devemos problematizar melhor o processo de ocupação do planalto.

A historiografia sobre povoamento do planalto de São Paulo pode ser classificada em quatro categorias explicativas. A primeira corresponde à interpretação de que o povoamento foi consequência do meio em que a vila fora instalada. A segunda, que teve uma maior repercussão nos estudos paulistas, corresponde à influência das bandeiras e entradas no processo de fixação do homem no planalto. A terceira, inaugurada por Sérgio Buarque de Holanda, destaca a referência da cultura portuguesa frente ao sertão e sua implicações. A quarta e última defende que o povoamento deve ser compreendido levando em consideração a lógica político-administrativa local e regional.

O estudo do povoamento do planalto teve como obra inicial os Capítulos de história colonial de João Capistrano de Abreu, de 1928. Nessa obra, o autor dedica o capítulo IX ao "Sertão", abordando o povoamento da colônia e, para tanto, inicia descrevendo o processo pioneiro de fixação do europeu no planalto piratiningano. Afirma que "o estabelecimento de Piratininga, desde a era de 530, na borda do campo, significa uma victoria ganha sem combate sobre a matta, que reclamou alhures o esforço de varias gerações. D'este avanço procede o desenvolvimento 
peculiar de São Paulo" 485 .

A ocupação foi, sobremaneira, influenciada pelas condições físicas do planalto. Capistrano justifica que "sob aquella latitude, naquella altitude, fôra possível uma lavoura semi-europea, de alguns, sinão todos os cereaes e fructos da península. Ao contrario o meio agiu como evaporador: os paulistas lançaram-se a bandeirantes ${ }^{4} 486$.

Separa, portanto, a ação dos bandeiristas das fundações das vilas próximas a São Paulo. Aponta que "antes da grande dispersão provocada pelos descobertos auríferos, a população agrupava-se nas margens do Tietê e nas do Parahiba. Na ribeira do Tietê, Mogy das Crurzes, Parnahiba, Itú, Sorocaba; na do Parahiba, Jacarehy, Taubaté, Guaratinguetá precederam os descobertos ${ }^{\prime 487}$.

Na obra Caminhos antigos e povoamento do Brasil, de 1930, Capistrano de Abreu conclui que "a situação geográfica de Piratininga impelia-a para o sertão, para os dois rios de cuja bacia se avizinha, o Tietê e o Paraíba do Sul, teatros prováveis das primeiras bandeiras, que tornaram logo famoso e temido o nome paulista" ${ }^{488}$. Sendo assim, ao tempo em que os conquistadores se batiam contra os índios de Paraguaçu e Ilhéus, prosperava à volta de São Paulo grande número de vilas: Moji das Cruzes, Parnaíba, Taubaté, Guaratinguetá, Itu, Jundiaí, Sorocaba, são todas anteriores a 1680, anteriores ao grande êxodo que assinalou o último quartel do século XVII" ${ }^{\$ 49}$.

Com isso, as vilas assumiram papel de relevo na época das bandeiras mas não tiveram suas origens relacionadas a elas, que lhes foram posteriores. Como indica Capistrano, "as vilas do Paraíba do Sul apontavam para as próximas Minas Gerais, como Parnaíba e Itu apontavam para Mato Grosso, como Jundiaí apontava para Goiás, e Sorocaba para os campos de pinheiros em que já

485 João Capistrano de Abreu. Capítulos de história colonial. Rio de Janeiro: Sociedade Capistrano de Abreu, 1928, p. 139.

486 Idem, p. 140.

487 Idem, p. 152.

488 João Capistrano de Abreu. Caminhos antigos e povoamento do Brasil. Belo Horizonte / São Paulo: Itatiaia, EdUSP, 1989, p. 44.

489 Idem, p. 45. 
surgia Curitiba"490.

Em 1942, Caio Prado Jr. publica a Formação do Brasil contemporâneo. Nessa obra, aborda a questão do povoamento da colônia e dedica importante parte ao "povoamento interior". De maneira geral, o autor apresenta que a distribuição demográfica "pelo território da colônia é, como logo se vê, grandemente irregular. Núcleos apenas, alguns bastante densos, mas separados uns dos outros por largos vácuos de povoamento ralo, se não inexistente" ${ }^{\text {491 }}$.

Isso se dá pela influência do meio no povoamento da colônia, influenciando sobremaneira as atividades econômicas. Nos primeiros séculos de colonização, anteriores às descobertas das minas, afora a fixação no litoral, Caio Prado apresenta "a modestíssima ocupação do bordo oriental do planalto meridional em São Paulo e no Paraná. Não me refiro aqui à penetração das bandeiras e entradas, que embora devassassem uma área interior, extensa, não são povoadoras e não passam de expedições. Não interessam diretamente à história do povoamento" ${ }^{492}$.

Dessa forma, Caio Prado destaca uma importante questão: a diferença entre desbravamento, ação nômade e instável e povoamento, fixação de população e desenvolvimento de atividade econômica.

Caio Prado Jr., em A cidade de São Paulo. Geografia e história, de 1983, retoma a discussão sobre a influência do meio na ocupação do planalto. Afirma que o planalto "apresenta ao povoador condições naturais muito mais favoráveis. Constituído de terras altas e saudáveis, de um clima temperado e por isso muito mais ao gosto de colonos europeus, oferecia atrativos consideráveis" ${ }^{493}$.

O povoamento de São Paulo foi, dessa forma, fortemente influenciado pela rede hidrográfica do planalto. "Partindo de São Paulo, o povoamento do planalto começa por seguir duas direções, ambas pelo Tietê: uma rio acima, outra rio abaixo. É seguindo estas linhas que os colonos se vão estabelecendo e formando as primeiras povoações e vilas" ${ }^{494}$.

490 Idem, p. 45.

491 Caio Prado Jr. Formação do Brasil contemporâneo: colônia. São Paulo: Brasiliense, 2007, p. 36.

492 Idem, p. 71.

493 Caio Prado Jr. A cidade de São Paulo. Geografia e história. São Paulo: Brasiliense, 1983, p. 9.

494 Idem, p. 21. 
O Tietê assume importante papel nessa rede de comunicações. Segundo Caio Prado,

antes do fim do século XVI encontramos no seu curso vário aldeamentos: Guarulhos, Itaquaquecetuba, São Miguel; a povoação, logo vila de Mogi das Cruzes; e passando para o Vale do Paraíba, São José dos Campos. Este setor da capitania torna-se logo a sua região mais povoada. No século XVII ele se povoa densamente, concentrando-se no vale do rio a grande maioria das populações e vilas da Capitania: além da citada São José, e para não lembrar senão as vilas, mais Jacareí, Taubaté, Pindamonhangaba, Guaratinguetá, Lorena $^{495}$.

A segunda interpretação, de que o povoamento no planalto fora influenciado pelas bandeiras, tem como principais autores Afonso Taunay, Ernani Silva Bruno, Washington Luís e, em uma perspectiva mais renovada, John Monteiro.

Afonso de Taunay, na obra monumental História geral das bandeiras paulistas, escrita entre 1924 e 1929, conclui, em relação ao povoamento do planalto, que "ha dous fócos iniciaes de irradiação paulista: São Vicente e São Paulo de Piratininga. Esta gera tres outros: Taubaté, Itu e Sorocaba. Destes tres centros partem as migrações colonizadoras que senhoreiam todo o Brasil central e meridional" ${ }^{\prime 496}$.

Assume a importância das bandeiras em todo o processo de desbravamento e fixação no sertão, indistintamente. Para Taunay, “os grandes fócos, porém, de expansão, conquista e povoamento são os da serra acima. Nelles é que se inicia aquele 'espantoso ondular das bandeiras', de que fala um historiador contemporâneo",497.

Washington Luís, em Na capitania de São Vicente, de 1956, adota postura próxima à de Taunay. Afirma que a transferência do pelourinho de Santo André para São Paulo se deu pela 
superioridade do sítio urbano dos jesuítas somado à preeminência religiosa da ordem.

Diferentemente de Taunay, Washington Luís não aborda o povoamento do planalto, dedicando grande parte de sua obra à narração dos feitos de grandes sertanistas. Enfoca seu papel como desbravadores ao afirmar que, “essas bandeiras, na faina insaciável do escravo e do ouro, mas trilhando, descobrindo, cruzando, revelando novos territórios em todas as direções, partiram durante largos anos ${ }^{\natural 998}$.

Ernani Silva Bruno, em Esboço da história do povoamento de S. Paulo, de 1967, apresenta uma posição mais crítica em relação à ação dos bandeiristas no povoamento do planalto, conciliando as ideias de Capistrano de Abreu e de Afonso de Taunay. Conclui que "se o bandeirismo ou sertanismo não foi um movimento povoador - no sentido de ocupação imediata de novas áreas territoriais - a verdade é que traçou caminhos e devassou terras que seriam mais tarde povoadas" ${ }^{499}$.

John Monteiro, em Negros da terra: índios e bandeirantes nas origens de São Paulo, de 1994, retorna a importância das bandeiras no processo de ocupação do planalto. Afirma que o movimento de desbravamento do sertão

acarretou a fundação na região de novas vilas por pioneiros paulistas, sendo que nos anos 1640-50 foram instalados pelourinhos em Taubaté, Guaratinguetá e Jacareí. Ao mesmo tempo, aventureiros da vila de Parnaíba trilhavam os sertões para o Oeste e Sul, chegando a estabelecer as vilas de Itu, Sorocaba e Curitiba. A noroeste, colonos de São Paulo fundaram a vila de Jundiaí ${ }^{500}$.

Difere dos autores clássicos dessa abordagem ao definir que o bandeirismo esteve profundamente influenciado por motivações econômicas. Aponta que "o desenvolvimento de cada

498 Washington Luís Pereira de Sousa. Na capitania de São Vicente. São Paulo: Martins, 1956, p. 179.

499 Ernani Silva Bruno. Esboço da história do povoamento de S. Paulo. In: São Paulo. Terra e povo. Porto Alegre: Globo, 1967, p. 6.

500 John M. Monteiro. Negros da terra: índios e bandeirantes nas origens de S. Paulo. São Paulo: Companhia das Letras, 1994, p. 81. 
uma dessas vilas refletia as novas orientações da busca pela mão de obra indígena" ${ }^{501}$.

No entanto, John Monteiro aproxima-se à terceira interpretação por nós proposta ao afirmar que "uma solução para contornar o problema da distribuição de terras era alcançada parcialmente

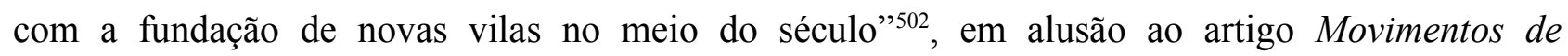
população... de Sérgio Buarque de Holanda, do qual iremos tratar adiante.

A terceira interpretação diz respeito à relação entre cultura e povoamento do planalto e teve Raízes do Brasil, de Sérgio Buarque como obra mais representativa. Nessa, ao tratar de forma comparativa as cidades castelhanas e portuguesas nas Américas, reforça a importância da cultura e mentalidades no esforço colonizador. Essa característica pode ser observada quando o autor apresenta que a colônia portuguesa "é simples lugar de passagem, para o governo como para os súditos" ${ }^{\prime 503}$.

Esse modelo mental, de explorar a terra sem nela cultivar fez com que "os portugueses criassem todas as dificuldades às entradas terra a dentro, receosos de que com isso se despovoasse a marinha" 504.

Em artigo de 1966, intitulado Movimentos da população em São Paulo no século XVIII (sic), Sérgio Buarque aborda a problemática do povoamento do planalto paulista. Dessa forma, procura compreender o fenômeno demográfico levando em conta fatores endógenos, como regime agrário, pestes, mortalidades, fomes gerais, não arrolamento de habitantes, sem contudo fechar uma causa específica.

Em relação à fundação de novas vilas, Sérgio Buarque descreve que "para organizar-se, entretanto, o aglomerado espontâneo em entidade municipal, era mister que atendesse a requisitos complicados, morosos e nem sempre coerentes..." ${ }^{, 505}$.

501 Idem, p. 81.

502 Idem, p. 107.

503 Sérgio Buarque de Holanda. Raízes do Brasil. Rio de Janeiro: José Olympio, 1948, p. 136.

504 Idem, p. 138.

505 Sérgio Buarque de Holanda. "Movimentos da população em São Paulo no século XVIII (sic)" Revista do IEB. São Paulo, 1966, p. 93. 
A quarta e última interpretação refere-se à relação entre povoamento do planalto e questões político-administrativas. Essa relação se dá por conta da diferenciação entre povoado e vila. A diferença reside no reconhecimento oficial e dotação de estrutura, tais como obrigações, privilégios e processo eleitoral, que competia somente às câmaras municipais.

A obra de Edmundo Zenha O município no Brasil, de 1948, inicia, de forma mais sistemática, a abordagem político-administrativa da ocupação do planalto. Afirma que "não se criam municípios no Brasil para a realização de obras públicas. Os povos, quando os pedem, querem policiar a terra, implantar nela um organismo de justiça, porque a del-rei era distante, demorada e cara" ${ }^{506}$. E que

é no município que as famílias daquele tipo [de destaque] encontram realização de sua tendência absorvente de empolgar, crescer, aumentar o prestígio. (...) E levam para ele [o município] não só suas afinidades como também seus antagonismos e ódios. Daí ter sido o município a única fórmula capaz de conseguir, no período colonial, apresentar realmente uma síntese da sociedade a que servia ${ }^{507}$.

Heloisa L. Bellotto, em Autoridade e conflito no Brasil colonial, de 1970, foi quem melhor soube relacionar o povoamento do planalto com as ações político-administrativas. Focando seu trabalho nos atos do Morgado de Mateus frente à capitania de São Paulo, aborda sua atuação nas questões de povoamento e desenvolvimento econômico regional. Afirma que "entre as atividades desenvolvidas pelo Morgado de Mateus frente à Capitania de S. Paulo, merecem destaque suas preocupações com a implantação de povoados. Sabia o quanto a fixação da população seria útil para o desenvolvimento social e econômico da capitania" ${ }^{508}$.

Dessa forma, quando o Morgado de Mateus inicia seu governo, havia no planalto dez vilas 506 Edmundo Zenha. O municipio no Brasil (1532-1700). São Paulo: I.P.E, 1948, p. 31. 507 Idem, p. 133.

508 Heloisa L. Bellotto. Autoridade e conflito no Brasil colonial. O governo do Morgado de Mateus. São Paulo: Alameda, 2007, p. 147. 
instaladas, incluindo São Paulo. Heloisa Bellotto, diversamente dos autores clássicos, não relaciona essas vilas ao fenômeno das bandeiras e consequências do meio. Defende que

o aparecimento de povoados sem ligação a um povoamento sistemático seria como 'tradição' paulista. Se os bandeirantes dá-se a alcunha de 'plantadores de cidades' seria de se esperar que, ao findar o seu ciclo, as linhas de rumo por eles traçadas tivessem permanecido significativamente povoadas. Entretanto, assim não ocorreu. A razão estaria em que, no caso de São Paulo, as atividades econômicas não tinham caráter sedentário ${ }^{509}$.

Relaciona, portanto, as observações de Sérgio Buarque de Holanda sobre os movimentos de população anteriores a 1765 com a diferenciação entre povoado e vilas constituídas.

Brasil Badecchi, em obra posterior, desenvolve as ideias iniciadas por Edmundo Zenha. Em O município no Brasil e sua função política, de 1972, defende que "relegado quase sempre para um segundo plano, o município não aparece com o devido destaque na História do Brasil. Não lhe negam justiça, mas não o proclamam no justo contorno que sua importância exige" ${ }^{510}$. Isso porque “tinham as Câmaras quase três séculos de tradição político-administrativa e não só administrativa como se depreende da simples leitura das leis" ${ }^{511}$.

Dessa forma, a partir da análise historiográfica sobre o povoamento do planalto, observamos a necessidade de considerarmos a questão político-administrativa. Estamos tratando, ao analisar as vilas do planalto, da criação de municípios reconhecidos pela Coroa e não simples aglomerações de populações. Devemos, portanto, compreender seu processo de criação e consolidação em um plano político e não observando seu "papel histórico" em eventos de maior destaque historiográfico, como as expedições ao sertão.

509 Idem, p. 147.

510 Brasil Bandecchi. O município no Brasil e sua função política. Separata de Revista de História, vol. XL, São Paulo, 1972, p. 11.

511 Idem, p. 13. 


\section{A questão do povoamento do planalto}

A partir dos elementos destacados por Sérgio Buarque acerca do povoamento do planalto, propomos estabelecer uma nova problemática sobre o tema. Conforme apontamos no capítulo anterior, observamos que a concessão de terras no rossio do município estava intimamente relacionada com a questão política. Dessa forma, a terra pertencente à Câmara municipal foi considerada pelos oficiais desta como patrimônio seu, repartindo-as entre os membros do poder local e seus familiares.

Propomos, portanto, ponderar esse aspecto de influência política na concessão de terras para compreender o povoamento do planalto paulista e a fundação de novas vilas.

Assim, para Sérgio Buarque, ao tratar das motivações que levaram os moradores a abandonarem São Paulo e fundarem novas vilas, estaria a ideia de "contrabalancear a exaustão das terras nas redondezas dos antigos núcleos, em particular da própria vila de São Paulo" ${ }^{512}$. Relata também que "quando a Câmara da vila de S. Paulo, chamada a opinar sobre a conveniência de erigir-se pelourinho em Mogi, corrobora uma afirmativa do capitão Gaspar Conqueiro, o qual, para justificar a medida, alegava haver na dita vila de São Paulo 'muyta gente e estarem apertados e não terem donde lavrarem ${ }^{m 513}$.

Portanto, podemos levantar a questão de que a fundação de novas vilas no planalto esteve condicionada à falta de terras. Porém, essa falta não se deu pelo esgotamento do solo ou por demais características naturais do sítio em que São Paulo se desenvolvera.

Ao contrário, vimos no capítulo anterior a estreita relação entre poder político e concessão de terras. Dessa forma, não seria impossível ponderar que a falta de terras estaria relacionada com dificuldade de acesso à mesma, visto que essas estariam sob o controle de um determinado grupo político. 
Acrescenta-se à hipótese a possibilidade dos fundadores das novas vilas serem pertencentes a grupos políticos que não conseguiram obter destaque na vila de origem e, consequentemente, optaram por fundar um novo núcleo municipal no qual pertenceriam à elite política, controlando os cargos da administração local.

Vale ressaltar que não estamos tratando de movimentos populacionais e sim da fundação de novos municípios. Poderiam esses moradores, se a questão fosse somente a escassez de solo cultivável, fundar freguesias, dependentes do núcleo de origem. Ao contrário, esses moradores optaram em constituir uma nova estrutura político-administrativa e ocupar cargos de destaque nelas.

Madalena Marques Dias, na dissertação A formação das elites numa vila colonial paulista: Mogi das Cruzes (1608-1646), aborda a questão da formação de novos núcleos administrativos. Afirma que fundar uma vila representava a "possibilidade de criação de uma estrutura própria" 514 e possibilitava ao morador do novo município "uma ascensão social verdadeira pois, com a institucionalização de suas novas condições - sesmeiros - poderiam concorrer aos cargos públicos criados, e ascender na escala social do 'bem viver"' 515 . E conclui que "poderiam, finalmente, entrar para o rol dos 'homens bons', o que sempre fora obstado a muito deles" 516.

Destacamos a passagem em que Madalena M. Dias aponta para o anseio de ser oficial da Câmara, representado pela expressão tradicional homem bom e o fato de tais cargos serem obstados a muito deles, ou seja, aponta que havia grupos políticos concorrendo ao controle político em um mesmo município.

Em uma perspectiva semelhante, Shirley dos Santos, ao abordar a fundação de Itu, conclui que

outras vilas também surgiam com rapidez em São Paulo seiscentista, passando por

514 Madalena Marques Dias. A formação das elites numa vila colonial: Mogi das Cruzes (1608-1646). São Paulo, 2001. Dissertação de mestrado. (História Econômica) - Faculdade de Filosofia, Letras e Ciências Humanas, Universidade de São Paulo, p. 67.

515 Madalena Marques Dias. op. cit., p. 67.

516 Madalena Marques Dias. op. cit., p. 67. 
uma trajetória similar à de Itu: do sertão, transformaram-se em povoados, sendo elevadas à categoria de freguesias e, depois, de vilas. Essa proliferação estava diretamente relacionada à exclusão da maioria das famílias paulistas do acesso aos mecanismos do poder político na vila de São Paulo. As famílias Pires e Camargo alternavam-se no controle da Câmara Municipal a partir de 1655, resultando na migração de várias famílias para o interior, cuja estratégia de garantia da posse era a ereção de vilas no solo recebido. ${ }^{517}$

Apesar dessas importantes constatações, Madalena M. Dias utiliza, para justificar a formação de novas vilas, o modelo de dispersão demográfica sugerido por Sérgio Buarque. Afirma que à concentração de propriedades "somava-se um regime predatório de utilização do solo baseado na queimada insistente do mesmo, e aí se perfilam três fatores de dispersão demográfica que levaram os colonos a procurarem novas terras numa direção apontada como ideal pelo governador" ${ }^{\prime 518}$.

Assim, a partir das afirmações apresentamos a proposta de compreender a fundação de vilas baseada em uma situação política. Para tanto, é necessário que relacionemos as concessões de terra em São Paulo com a fundação de vilas para verificar se há relações.

Apresentamos abaixo um gráfico que representa a distribuição de terras urbanas entre 1560 e 1765. Como a finalidade é verificar a distribuição em um período mais abrangente, organizamos as datas de terras em séries de decenais.

Observando o gráfico 5, podemos notar que a concessão de terras não seguiu uma tendência de crescimento, acompanhando o povoamento e desenvolvimento econômico do núcleo de São Paulo. Percebemos, contudo, que a concessão apresenta picos seguidos de quedas abruptas. Portanto, para podermos refletir melhor sobre essas tendências, devemos cruzá-las com os eventos internos da vida do município e também das novas vilas fundadas no planalto.

517 Shirley dos Santos. Vila de Itu: a cristandade na boca do sertão (1732-1776). São Paulo, 2004. Dissertação de mestrado (História Social) - Faculdade de Filosofia, Letras e Ciências Humanas, Universidade de São Paulo, p. 4445.

518 Madalena Marques Dias. op. cit., p. 48. 
Gráfico 5 - Distribuição de Terras por Decênio

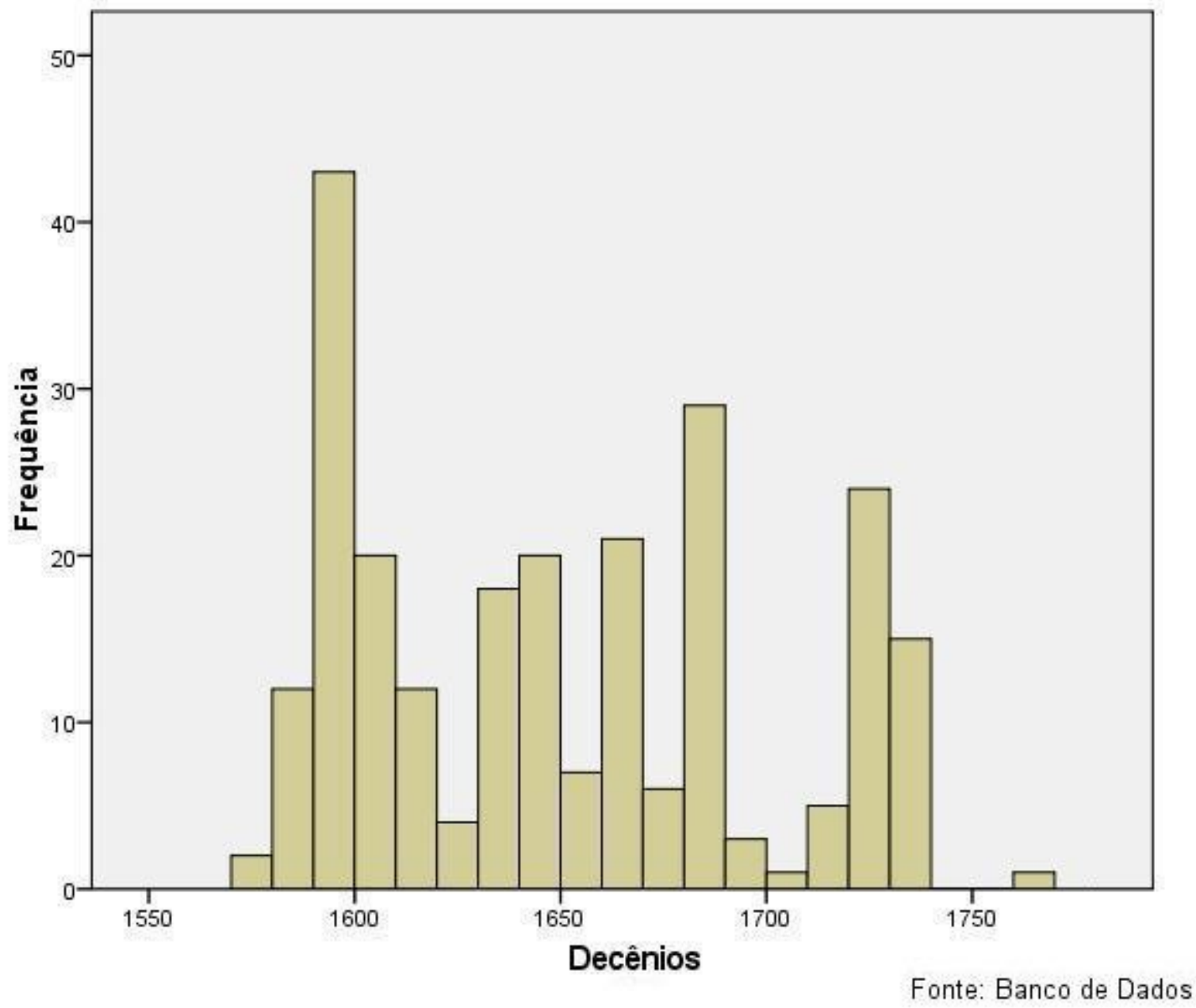


Conforme descrevemos anteriormente, as vilas fundadas a partir de São Paulo foram seis, concentradas na primeira metade do século XVII e início da segunda metade do XVII. As vilas foram: Mogi, em 1611; Parnaíba, em 1625; Taubaté, em 1650; Jacareí, em 1653; Jundiaí, em 1655 e Guaratinguetá, em 1657. Vale ressaltar que as vilas de Itu e Sorocaba, fundadas em 1657 e 1661, respectivamente, foram originadas de Parnaíba e Pindamonhangaba, de 1705, surgiu a partir de disputas locais em Taubaté.

Retomando a análise do gráfico, observamos que a fundação de novas vilas é antecedida por uma queda das concessões de terra. E, após a criação de um novo núcleo, com termo e rossio próprios para conceder a propriedade a novos moradores, notamos que há uma retomada de concessões na vila de São Paulo.

Os anos entre 1653 e 1660, que concentram a fundação de três vilas, corresponde ao período de conflito entre as famílias Pires e Camargos em torno da disputa pelo controle político na vila de São Paulo. A contenda, descrita por Azevedo Marques, foi iniciada por conflitos nas eleições municipais de 1653. A esse episódio seguiram vários eventos que marcaram profundamente o cotidiano político da vila, até que, em 1655, através de um alvará e provisão régia que concedeu perdão às famílias, a hostilidade entre os grupos serenou ${ }^{519}$.

Apesar da ausência de documentação sobre os conflitos nas Atas da Câmara, podemos afirmar que, dadas as dimensões das disputas, o elemento político assumiu grande importância na vila local de São Paulo à época.

Outro evento da história de São Paulo que deve ser retomado é a correição do ouvidor-geral João da Rocha Pitta sobre as terras de índios da aldeia de S. Miguel. Conforme nos aponta Sylvio Bomtempi, o ouvidor concede à Câmara de São Paulo a área de seis léguas que fôra concedida em 1580 aos índios da referida aldeia ${ }^{520}$.

Com o aumento significativo da área de propriedade da Câmara, notamos um pico de 
concessões de terra. No entanto, esse evento não alterou o panorama de propriedades em São Paulo, pois nesse período, grande parte das datas de terra oficializadas em S. Miguel foram descritas como regularização de posses na área, muitas havia várias décadas.

Esse é o caso da carta de Balthazar da Costa Veiga, que solicita a regularização de sua propriedade "na paragem chamada o Angra pertencente aos indios de S. Miguel”, alegando "o juízo do doutor João da Rocha Pitta cuja sentença offerece ao supplicante" ${ }^{\text {521 }}$.

Retomando mais uma vez o gráfico, podemos observar que após a fundação das novas vilas, há uma retomada das concessões de terra, como se houvesse alívio de uma pressão. A essa pressão e seu consequente alívio, podemos pensá-los a partir das reflexões sobre safety-valve tecidas por Sérgio Buarque.

Esse conceito, formulado nos Estados Unidos, é, segundo Sérgio Buarque a ideia “de que o Oeste norte-americano, área largamente desocupada que se abria além da fronteira do povoamento regular, devia agir ao modo de uma válvula de segurança para resguardar o Leste atlântico do risco de perturbações internas que sem ela pareciam inevitáveis" ${ }^{522}$.

Dessa forma, continua o autor que

a sua maneira, a função que vinham tendo no século XVII os espaços livres e utilizáveis ainda existentes ao redor do velho núcleo piratiningano, de assegurar a sobrevivência do tipo de sociedade ali formada desde os inícios da colonização, assemelhava-se, rigorosamente, à espécie de safety valve que há cem anos inflamara a imaginação anglo-saxônica no norte do continente. Se diferença houvesse, estaria nisso, que aqueles espaços livres, em vez de tingidos de cores tão idílicas, deveriam parecer, em geral, uma realidade descolorida e chã, mais refrigério do que esperança. ${ }^{523}$

Dessa forma, procurarmos utilizar o conceito estabelecido por Sérgio Buarque e cotejá-lo

521 Carta XLV. Cartas de datas de terra. São Paulo: Departamento de Cultura, 1937, vol. III.

522 Sérgio Buarque de Holanda. "Movimentos da população em São Paulo no século XVIII (sic)" Revista do IEB. São

Paulo, 1966, p. 104.

523 Sérgio Buarque de Holanda. op. cit., p. 105. 
com a questão política do uso das terras da Câmara. Portanto, verificamos que as terras disponíveis no rossio e termo de São Paulo dificilmente poderiam ser concebidas como válvula de escape, visto que essas estavam sujeitas ao controle dos oficiais da Câmara, responsáveis em grande parte pela concentração das terras do município nas mãos dos que pertenciam ao grupo que estava no poder ou à famílias próximas.

Pretendemos, no entanto, aplicar o modelo de safety valve em uma área mais ampla. Não iremos pensar nas terras ao redor da vila, dentro de sua área de influência administrativa. Mas iremos pensá-lo levando em consideração as fundações de novas vilas no sertão.

Conforme abordamos anteriormente, a análise da distribuição de terras em São Paulo sofre variações quando surgem novos municípios no planalto. Seria como se, com a fundação de vilas, dotadas de estrutura político-administrativa próprias, aliviasse a pressão local em São Paulo.

A partir dessas observações, podemos, portanto, estender a expressão de Sérgio Buarque de safety valve para o povoamento do planalto, mais especificamente para a criação de novas vilas. Essas novas estruturas poderiam contemplar grupos políticos que não pertenciam ao comando da vila de São Paulo. E, não podendo superá-lo na vila de origem, procura fundar uma nova estrutura, em que seria o grupo dominante.

O que notamos é que esse movimento de criar novos municípios tem uma evidente relação com a manutenção de um equilíbrio político e não por conta de pressões demográficas. O safety valve no planalto seria responsável por manter a paz entre os grupos políticos, preservando o equilíbrio político e social. Evitando, portanto, conflitos como os ocorridos entre as famílias Pires e Camargo, que marcaram profundamente a história política de São Paulo.

A favor dessa interpretação, temos o conflito entre as câmaras de Parnaíba e São Paulo. Afonso Taunay apresenta essa situação como protesto da Câmara paulistana devido a fundação da nova vila parnaibana, ao escrever que "com a fundação de Parnahyba ficaram os paulistas furiosos. Não admittiam que se lhes desmembrasse o sertão. Um sertão tão pequeno, que ia sómente até o 
coração da America do Sul" ${ }^{24}$.

No entanto, obstante a expressão literária de Taunay, o problema não estava em se fundar uma nova vila. Mogi havia sido fundada antes de Parnaíba, sem que houvesse objeção da Câmara paulistana. O problema, na realidade, residia na disputa de patrimônio entre as duas câmaras. A nova vila, fundada em 1625, situava-se a oito léguas de São Paulo. Dessa forma, o termo, patrimônio da vila que era definido por um raio de seis léguas, estaria sobreposto ao de São Paulo.

Taunay relata que "estava Parnahyba a 8 leguas de São Paulo e elle ouvidor [Álvaro Luiz do Valle], levara o territorio paulistano até Barueri, a seis leguas de S. Paulo. Dahi em deante seria Parnahyba" ${ }^{225}$. Optou, portanto, o ouvidor, em preservar o termo de seis léguas da vila de São Paulo, devido a sua antiguidade e reduzir a leste o termo de Parnaíba, que ficaria com duas léguas.

Apesar da aparente solução, a disputa não se encerrou. Logo após a decisão do ouvidor, a Câmara de Parnaíba procurou recorrer da decisão.

Após várias demarcações e contestações, ressaltamos a sessão de 7 de julho de 1730, registrada nas Atas da Câmara de São Paulo. Nessa,

foi mandado ao procurador do comçelho que fizeçe hua petiçam ao Doutor ouvidor geral para efeito de mandar noteficar os officiais da camara da villa de Paranahyba comsignandoçelhe tempo em que elles manden procurador para assistir a mediçam dos lemites em que ahy duvida a cuja mediçam hade asistir e ser feita pello dito Doutor Ouvidor geral a vista desta e aquela camara. ${ }^{526}$

Assim, vemos que a disputa pelo termo entre São Paulo e Parnaíba avançou até o ano de 1730. Não iremos, contudo, esmiuçar essa questão. Pretendemos somente explicitar que essa disputa, ao contrário do apontado por Taunay, não diz respeito à restrição por parte de São Paulo de fundar-se novas vilas, e sim da proteção ao patrimônio da Câmara em contestação.

524 Afonso de E. Taunay. História seiscentista da vila de São Paulo. São Paulo: Ideal, 1926, p. 277, vol. I. 
Outro argumento que corrobora a favor do conceito de válvula de segurança aplicado à fundação de vilas é o conflito entre grupos pelo controle político da administração muncipal. Aponta Taunay que "nas actas seiscentistas da Camara de S. Paulo numersas são as flagrantes demonstrações de quanto reinava na politica municipal o espirito de bellicosidade que tanto era o caracteristico dos cidadãos de Piratininga naquella centuria essencialmente bandeirante" ${ }^{927}$. Continua sua apresentação do cotidiano político de São Paulo afirmando que "frequentes foram e por diversas causas as questões entre vereadores ou entre estes e os magistrados, que afinal vieram a tomar uma feição generalisadora terminada tão longo quanto sangrento conflito chamado dos Pires e Camargos" ${ }^{528}$.

Em meio ao conflito, ocorre o assassinato de Pedro Taques por Fernão de Camargo, o que potencializa ainda mais o conflito. Taunay descreve que

o terrivel dissidio dos Pires e Camargos que quasi anniquilou S. Paulo trouxe grandes beneficios a Parnahyba. Assassinado Pedro Taques e dominado os Camargos a villa piratiningana, para Parnahyba transferiu seu irmão Guilherme Pompeu de Almeida potentado em arcos, e pae do famoso créso parnahybano padre dr. Guilherme Pompeu de Almeida. A Pompeu acompanharam numerosos vultos notaveis de seu partido. ${ }^{529}$

Dessa forma, vemos que, no caso de Parnaíba, a relação política foi fundamental para a estruturação do poder no novo município. O conflito entre Pires e Camargos foi, em parte, abrandado quando da transferência do grupo político perdedor para uma outra vila.

Assim, procurou-se preservar o equilíbrio político do planalto. Quando um grupo político começa a destacar-se em São Paulo e encontra obstáculos em exercício de mandatos políticos, a solução escolhida passa a ser fundar uma nova estrutura político-administrativa. Evitava-se, 
portanto, que conflitos sangrentos se repetissem na vila piratiningana, além de possibilitar uma fixação mais efetiva do europeu em meio ao sertão americano.

\section{Conclusão}

A estruturação do modelo de safety-valve permitiu, dentro do possível, a preservação da ordem e estabilidade política e social no planalto. E tal equilíbrio só foi garantido pelas características patrimonialistas da administração municipal de São Paulo.

Podemos afirmar, a partir das observações feitas, que o patrimonialismo não foi um fenômeno isolado na vila de São Paulo. Ao limitar o acesso à terra urbana, a Câmara paulistana criou condição para que grupos políticos emergentes criassem novos municípios.

Com essas novas vilas, a estrutura patrimonialista é reproduzida e o previne-se conflitos políticos pelo controle da administração municipal.

Tal panorama foi alterado em 1765, quando teve o início o governo de D. Luis Antonio de Souza Botelho Mourão, o Morgado de Mateus, na capitania de São Paulo. O governador empreendeu reformas na capitania visando garantir sua defesa e desenvolvimento econômico. De acordo com Heloísa L. Bellotto, “entre as atividades desenvolvidas pelo Morgado de Mateus à frente da Capitania de São Paulo, merecem destaque suas preocupações com a implantação de povoações. Sabia o quanto a fixação da população seria útil para o desenvolvimento social e econômico da capitania" ${ }^{530}$.

Para permitir que seus objetivos para a capitania fossem efetivados, "em dezembro de 1766, D. Antonio já tinha, bem estruturado, um plano de trabalho no sentido da fundação de povoações: 'tenho disposto mandar formar seis em diferentes partes que me pareceram as mais proprias e as mais uteis pela sua cituação, comodidade e fertilidade do Paiz"',531. 
A partir deses planos, foram fundados vários povoados e alguns deses foram elevados à condição de vila, dependendo do seu crescimento demográfico e incremento das atividades econômicas.

Essa mudança de padrão de povoamento, como assinala Sérgio Buarque de Holanda, não foi bem aceita pelas elites locais da capitania de São Paulo. Um governador que inicia uma administração com planos de mudanças de estruturas locais de poder político não iria encontrar apoio das câmaras municipais.

Segundo Heloísa Bellotto, “as novas povoações seriam destinadas à gente dispersa, sem domicílio e sem ocupação e, portanto, sem recursos" ${ }^{532}$. O que muda profundamente a função e a composição dos novos povoados. Antes de 1765, um grupo político ou familiar instalava-se em um local, criava um povoado e depois obtinha o título de um novo município no qual exerceria o poder. Após a administração do Morgado de Mateus, essa ação passa a ser organizada pelo governo e não mais decorrente de arranjos entre grupos políticos ou familiares locais.

Com essa alteração da estrutura de arranjos políticos, inicia-se a oposição entre oficiais da Câmara e o novo governador. De acordo com H. Bellotto, “constituíam-se os vereadores de São Paulo em grupos, cujos membros ligados entre si dispunham do governo das vilas, segundo seus caprichos e interesses" 533 . E, em defesa de seu plano de reformas, "a principal acusação do Morgado de Mateus contra as Câmaras era de que, formando uma força política, local, pretendiam sempre ir além de suas prerrogativas legais" ${ }^{534}$.

Sobre a questão, o próprio Morgado escreve que "os republicanos, deixada a economia particular das terras que deve estar a seu cargo, cuidão com demaziado zello no governo geral da Capitania que lhes não pertence, zello que pelo credito que lhes adquire com os povos, e pelas consequencias que podem ter para o futuro se lhe deve prudentemente atalhar [...] ${ }^{\text {,535. }}$.

532 Heloísa L. Bellotto. op. cit., p. 158.

533 Heloísa L. Bellotto. op. cit., p. 220.

534 Heloísa L. Bellotto. op. cit., p. 220.

535 AHU, Lisboa, “São Paulo", Doc., n 2409. Apud Heloísa L. Bellotto. op. cit., p. 220. 
A situação do povoamento da capitania de São Paulo, com suas poucas vilas no planalto não corresponde a uma questão demográfica. Havia, dispersos nos seus sertões, pessoas vivendo em lavouras, em pousos e no comércios nas estradas. "Aos 'vadios e facinorozos que vivem como feras, separados da sociedade civil e do commercio Humano' era ordenado que abandonassem os 'sitios volantes' e escolhessem 'lugares accomodados, para viverem juntos em Povoações Civis que pelo menos tenhão de cincoenta fogos para cima' [...]"536.

Esses dispersos, provavelmente os excluídos das concessões de terra por não terem vínculos com o poder local, tiveram de viver no sertão, onde houvesse terra livre para cultivar. Tal situação corrobora com a nossa interpretação acerca do uso político das terras da Câmara e dos rearranjos políticos na formação de novas vilas.

Dessa forma, vemos que a fundação de novas vilas no planalto, até 1765 , foi pautada principalmente pela necessidade de preservação da harmonia entre as forças políticas locais. Somente assim é que compreendemos a distribuição geográfica desigual das vilas e os longos intervalos entre as fundações.

As mudanças impostas pelo Morgado de Mateus destruíram esse sistema que visava garantir a segurança política do planalto. Certamente por isso, nas palavras de Heloísa Bellotto,

a ligação entre elementos da 'aristocracia' local, os camaristas e os oficiais da Justiça representaria, para o governador, uma sólida trama a entravar-lhe não só o bom andamento da administração, mas todo o sistema administrativo colonial. Dessa visão que tinha o Morgado de Mateus desses elementos locais de poder originara-se, provavelmente, a sua constante má vontade para discutir, em bons termos, as questões que se levantaram contra eles. ${ }^{537}$

536 Heloísa L. Bellotto. op. cit., p. 150-151.

537 Heloísa L. Bellotto. op. cit., p. 275. 
Considerações Finais 
A Câmara de São Paulo foi estabelecida em 1560 com a instalação do município, de acordo com os princípios regidos pelas Ordenações do Reino. Essa legislação possibilitava uma ampla autonomia de funcionamento aos municípios, cabendo a eles administrar suas propriedades, finanças e segurança.

O objetivo dessa pesquisa foi compreender a estrutura de funcionamento da Câmara de São Paulo, visto que não há um registro formal de normas e procedimentos. Para tanto, abordamos as relação dos oficiais da Câmara com uma de suas ações práticas, a concessão de terras no termo do município.

Verificamos, através dessa relação, que a estrutura de poder em São Paulo revela que a atuação dos oficiais foi principalmente de caráter patrimonialista. Isso porque há relação direita entre os ocupantes de cargos camarários e os requerentes de terras municipais.

Observamos que 51,44\% das solicitações de terras urbanas foram feitas por indivíduos que ocuparam cargos na administração municipal e 16,87\% dos requerentes tinham vínculos familiares próximos com os grupos políticos locais.

Desses com vínculos familiares, 26,8\% eram de filhos, $24,4 \%$ de genros e $14,6 \%$ de irmãos de oficiais da Câmara. Valores esses que nos permitem inferir a utilização do poder de conceder terras dentro do termo como estratégia de fortalecimento de grupos políticos familiares.

O caráter patrimonialista das relações de cessão de propriedades pode ser melhor observado quando verificamos as argumentações nos pedidos à Câmara. 27,6\% dos requerentes alegam "necessidade de mais terras" e 13,6\% justificaram o pedido por "recompensa por serviços prestados". Esses argumentos reforçam a interpretação por nós formulada de que a propriedade da Câmara foi, no período colonial por nós estudado, vista como propriedade dos oficiais dela.

A partir dessa concepção, compreendemos melhor a urbanização da vila e o aparente caráter desorganizado de sua ocupação. A confusão entre público e privado, através do favorecimento de grupos na distribuição de terras, influenciou sobremaneira a formatação espacial da vila. 
A preocupação dos oficiais da Câmara residia no controle do acesso à terra, considerando essa como forma de manter seu grupo no poder. Não havia atenção às questões urbanísticas renascentistas, como formatação de ruas e organização racional do tecido urbano.

Partimos da compreensão da estrutura da Câmara Municipal de São Paulo, seguindo a interpretação patrimonialista no conceito weberiano. Com o estudo das relações da Câmara com as vilas fundadas no planalto, observamos a mesma estruturação do poder local em nível regional.

A política de urbanização e desenvolvimento econômico da capitania de São Paulo, implantado pelo Morgado de Mateus em meados do século XVIII, rompeu com a estrutura existente de poder local nos municípios. Ao fundar novas vilas e equipará-las às tradicionais, o governador acabou com os privilégios dos grupos que controlavam o poder local no planalto nas mais antigas povoações.

O equilíbrio entre os grupos políticos locais foi rompido, mas não de forma suficiente para eliminar o caráter patrimonialista da administração local no planalto paulista. O patrimonialismo não se encerrou com as reformas ilustradas do século XVIII, continuando a influenciar a política e a sociedade brasileira até os dias atuais. 
Referências Bibliográficas 


\section{Fontes}

$13^{\mathrm{a}}$ sessão ordinária em 20 de julho de 1915. Revista do IHGSP. São Paulo, v. 19, 1914.

$15^{\mathrm{a}}$ sessão ordinário em 20 de outubro de 1899. Revista do IHGSP. São Paulo, v. 4, 1898-1899.

Actas da Câmara de S.to André da Borda do Campo. São Paulo: Duprat \& Ca , 1914, 1 vol.

Actas da Câmara de São Paulo. São Paulo: Duprat \& Ca , 1914, v. 1-15.

Cartas de datas de terra de São Paulo. São Paulo: Departamento de Cultura, 1937, v. 1-4.

Colleção das Leis do Imperio do Brazil: 1828. Rio de Janeiro: Typ. Nacional, 1878.

Constituição de 1891. Brasília: Senado Federal, 2001.

Estatutos da Universidade de Coimbra (1772). Coimbra: Universidade de Coimbra, 1972. (edição fac-similar).

Las siete partidas del sabio Rey don Alonso el nono: nuevamente glosadas por el Licenciado Gregorio López del Consejo Real de Indias de su Magestad. Madri: Boletin Oficial del Estado, 1974, 3 vol.

Ordenações Afonsinas. Lisboa: Calouste Gulbenkian, 1984.

Ordenações Manuelinas. Lisboa: Calouste Gulbenkian, 1984.

Ordenações Filipinas. Rio de Janeiro: Inst. Philomathico, 1870.

Portugaliae Monumenta Historica, Leges et Consuetudines. Olisipone: s.1., 1868.

Registro geral da Câmara de São Paulo. São Paulo: Câmara Municipal, 1937, v. 1-22.

Relatório de 1914 apresentado á Câmara Municipal de S. Paulo pelo prefeito Washington Luiz Pereira de Souza. São Paulo: Casa Vanorden, 1916.

\section{Bibliografia Consultada}

AB'SÁBER, Aziz N. Geomorfologia do sítio urbano de São Paulo. São Paulo: Ateliê, 2007.

ABUD, Katia M. Sangue intimorato e as nobilíssimas tradições: a contribuição de um símblo paulista: o bandeirante. São Paulo, 1986. Tese de doutorado (História Social) - Faculdade de Filosofia, Letras e Ciências Humanas, Universidade de São Paulo.

ALMEIDA, Cândido Mendes de. Os Códigos Portuguezes - Affonsino, Manoelino, Sebastianico e Philippino. Ordenações Filipinas, liv. I. Rio de Janeiro: Inst. Philomathico, 1870, p. XIX.

ANDRADE, Margarida Maria de. Bairros do além-Tamanduateí: o imigrante e a fábrica no Brás, 
Mooca e Belenzinho. São Paulo, 1991. Tese de doutorado (Geografia Humana) - Faculdade de Filosofia, Letras e Ciências Humanas, Universidade de São Paulo.

ARQUIVO Municipal Washington Luís. Guia do Arquivo Histórico Municipal Washington Luis. São Paulo: DPH, 2007.

AVELLAR, Hélio de Alcântara. A administração pombalina. In: Vicente Tapajós (org.). História Administrativa do Brasil. Rio de Janeiro: Imprensa Nacional, 195-, vol. 5.

. Preliminares Européias. In: Vicente Tapajós (org.). História Administrativa do Brasil. Rio de Janeiro: Imprensa Nacional, 1956, vol. 1.

AZEVEDO, Aroldo de. Vilas e cidades do Brasil colonial. São Paulo: FFCL-USP, 1956.

AZEVEDO, Luiz Carlos de. História do direito, ciência e disciplina. Revista da Faculdade de Direito da Universidade de São Paulo. São Paulo, v. 92, jan/dez, 1997.

. Origem e introdução da apelação no direito luso-brasileiro. São Paulo, 1976. Dissertação de mestrado (Mestrado em Direito) - Faculdade de Direito, Universidade de São Paulo.

AZEVEDO MARQUES, Manuel Eufrásio de. Apontamentos históricos, geográficos, biológicos, estatísticos e noticiosos da província de São Paulo. São Paulo: Martins, 1954, 2 v.

BANDECCHI, Brasil. O município no Brasil e sua função política. São Paulo: s.n., 1964.

BELLOTTO, Heloísa, L. Arquivos permanentes: tratamento documental. Rio de Janeiro: EdFGV, 2008.

(1765-1775). São Paulo: Alameda, 2007. [1 $1^{\mathrm{a}}$ edição, 1976].

BENEVOLO, Leonardo. História da cidade. São Paulo: Perspectiva, 1993.

BICALHO, Maria Fernanda B.. As Câmaras Municipais no Império Português: o caso do Rio de Janeiro. Revista Brasileira de História, vol. 18, n. 36, 1998.

. A cidade e o Império. Rio de Janeiro: Civilização Brasileira, 2003.

BLAJ, Ilana. A trama das tensões: o processo de mercantilização de São Paulo colonial (16811721). São Paulo, 1995, Tese de doutorado (História Social) - Faculdade de Filosofia, Letras e Ciências Humanas, Universidade de São Paulo.

BLUTEAU, Raphael. Vocabulário portuguez, e latino, aulico, anatomico, architectonico, bellico, botanico... et alii. Coimbra: Collegio das Artes da Companhia de Jesus, 1712.

BOMTEMPI, Sylvio. O bairro de São Miguel Paulista. São Paulo: DPH, 1970.

BOXER, Charles. O Império maritimo português: 1415-1825. São Paulo: Companhia das Letras, 2005. [1 $1^{\text {a }}$ edição, 1969]. 
BRAGA DA CRUZ, G.. O direito subsidiário na história do direito português. In: . Obras esparsas. Coimbra: Universidade de Coimbra, 1981, vol. II.

BRUNO, Ernani Silva. São Paulo. Terra e povo. Porto Alegre: Globo, 1967.

BURKE, Peter. A Escola dos Annales. A revolução francesa da historiografia. São Paulo: EdUNESP, 1997.

CANABRAVA, Alice P. História Econômica: estudos e pesquisas. São Paulo: EdUNESP; ABPHE, 2005.

CAETANO, Marcelo. História do direito português: fontes de direito (1140-1495). Lisboa: Verbo, 1992.

Ultramar, 1967.

O Conselho Ultramarino: esboço de sua história. Lisboa: Agência Geral do

CAPELATO, M. H. R, GLEZER, R., FERLINI, V. L. A escola uspiana de História. Revista do Instituto de Estudos Avançados. São Paulo, vol. 8, n. 22, set./dez. 1994.

CAPISTRANO DE ABREU, J. Caminhos antigos e povoamento do Brasil. São Paulo, Belo Horizonte: EdUSP, Itatiaia, 1989, [1ª edição, 1930].

CARMIGNANI, M. Cristina da Silva. O direito judiciário na história: a experiência romana e luso-brasileira. São Paulo, 2002. Tese de doutorado (Doutorado em Direito) - Faculdade de Direito, Universidade de São Paulo.

CHAUNU, Pierre. A história como ciência social. Rio de Janeiro: Zahar, 1976.

. L'histoire geographique. Revue d'anseignement supérieu. Paris, 1960, n. 44-45,

pp. 66-77.

DEL BRENNA, Giovanna. Medieval ou barroco? Proposta de leitura do espaço urbano colonial. Barroco. Belo Horizonte, 12, 1982-1983, p. 141-145.

. Projetos urbanos para o Rio de Janeiro em meados do século XVIII. Lisboa iluminista e o seu tempo. Actas de colóquio, 26, 27 e 28 de outubro de 1994. Lisboa: Universidade Autónoma de Lisboa, p. 267-280.

DIAS, Madalena Marques. A formação das elites numa vila colonial: Mogi das Cruzes (16081646). São Paulo, 2001. Dissertação de mestrado (História Econômica) - Faculdade de Filosofia, Letras e Ciências Humanas, Universidade de São Paulo.

DOMINGUES, José. Ordenações Afonsinas. Coimbra: Almedina, 2007.

EDITORIAL, Revista do Serviço Público. Rio de Janeiro, vol. 2, n. 1, abr. 1944. 
EDITORIAL. Revista do Serviço Público. Rio de Janeiro, vol. 66, n. 1, jan. 1955.

EDITORIAL. Revista do Serviço Público. Rio de Janeiro, vol. 88, n. 1, jul. 1960.

ELLIS Jr. Alfredo. Raça de gigantes. São Paulo: Helios, 1926.

FAORO, Raimundo. Os donos do poder: formação do patronato brasileiro. Porto Alegre: Globo, 1975, 2a. edição.

FERNANDES, Florestan. Circuito fechado, quatro ensaios sobre o 'poder institucional'. São Paulo: Hucitec, 1977.

FERREIRA, Manoel Rodrigues. A evolução do sistema eleitoral brasileiro. Brasília: Senado Federal, 2001.

FLEIUS, Max. História Administrativa do Brasil. São Paulo: Melhoramentos, 1922.

FRANÇA, Eduardo D'Oliveira. Portugal na época da Restauração. São Paulo: Hucitec, 1997, [1 ${ }^{\mathrm{a}}$ edição, 1951].

FURET, François. L'histoire quantitative et la construction du fait historique. Annales. Économies, Sociétés, Civilisations, 1971, vol. 26, n. 1, pp. 63-75.

GLEZER, Raquel. Chão de terra e outros estudos sobre São Paulo. São Paulo: Alameda, 2007. [1 ${ }^{\mathrm{a}}$ edição, 1992].

GILISSEN, John. Introdução histórica ao direito. $5^{\mathrm{a}}$ ed. Lisboa: Calouste Gulbenkian, 2008.

GOMES DA SILVA, Nuno Espinosa. História do direto português: fontes de direito. Lisboa: Calouste Gulbenkian, 2006.

GUEDES, João Alfredo Libânio. União Ibérica. In: Vicente Tapajós (org.). História Administrativa do Brasil. Rio de Janeiro: Imprensa Nacional, 1956, vol. 3.

. Da Restauração a D. João V. In: Vicente Tapajós (org.). História Administrativa do Brasil. Rio de Janeiro: Imprensa Nacional, 195-, vol. 4.

HESPANHA, António Manuel. As vésperas do Leviathan, Coimbra: Almedina, 1994.

Aberta, 1995. . História de Portugal moderno: político e institucional. Lisboa: Universidade

HESPANHA, António M. e SANTOS, M. Cristina. Os poderes num império oceânico. In MATTOSO, José (org.). História de Portugal. Lisboa: Estampa. 199-.

HOLANDA, Sérgio Buarque de. Caminhos e fronteiras. São Paulo: Companhia das Letras, 2005, [1ª edição, 1957]. . Monções. Rio de Janeiro: C.E.B., 1945. 
$\overline{\text { Revista do IEB, } \mathrm{n}^{\mathrm{0}}}$ 1, 1966.

. Movimentos da população em São Paulo em meados do século XVIII (sic). . Raízes do Brasil. São Paulo: Companhia das Letras, 2005, [2a edição, 1947].

KANTOR, Íris. Esquecidos e renascidos: historiografia acadêmica luso-americana (1724-1754). São Paulo; Salvador: Hucitec; CEB-UFBA, 2004.

LAPA, José Roberto do Amaral. Historiografia brasileira contemporânea: a História em questão. Petrópolis: Vozes, 1981.

LAXE, João Baptista C.. Câmaras municipais (histórico). Rio de Janeiro: B. L. Garnier, 1885.

LEPETIT, Bernard. L'histoire quantitative: deux ou trois choses que je sais d'elle. Histoire \& mesure, 1989, vol. 4, n. 3, p. 191-199.

LIMA, Graziela F. Buscarin. Evolução histórica da propriedade territorial no Brasil. São Paulo, 2002. Dissertação de mestrado (Mestrado em Direito) - Faculdade de Direito, Universidade de São Paulo.

LIMA, Ruy Cirne. Pequena história territorial do Brasil: sesmarias e terras devolutas. Goiânia: EdUFG, 2002. [1ª edição, 1954].

MACHADO, Alcântara. Vida e morte do bandeirante. São Paulo: Imprensa Oficial, 2006. [1 ${ }^{\mathrm{a}}$ edição, 1929].

MADRE DE DEUS, frei Gaspar. Memórias para a História da Capitania de S. Vicente. São Paulo: Comissão do IV Centenário da Cidade de São Paulo, 1954. [1ª edição, 1797]

MAGALHÃES, Joaquim Romero. Algarve económico durante o século XVI. Lisboa: Cosmos, 1970.

MATTOS, Olgária. Revolução estudantil dos anos 60. In NAKANO, Y., REGO, J. e FURQUIM, L. (org.). Em busca do novo. O Brasil e o desenvolvimento na obra de Bresser-Pereira. Rio de Janeiro: EdFGV, 2004, pp. 297-311.

MARCÍLIO, Maria Luíza. São Paulo: povoamento e população. São Paulo: Pioneira, 1974.

MENDONÇA, Marcos Carneiro de. Raízes da formação administrativa do Brasil. Rio de Janeiro: IHGB, 1972, tomo I.

MARQUES, Mário Reis. História do direito português medieval e moderno. Coimbra: Almedina, 2002.

MARX, Murillo. Cidade brasileira. São Paulo: Melhoramentos, 1980.

. Nosso chão: do sagrado ao profano. São Paulo: EdUSP, 1989. 
MERÊA, M. Paulo. A solução tradicional da colonização portuguesa no Brasil. In: História da Colonização Portuguesa no Brasil. Edição Monumental Comemorativa do Primeiro Centenário da Independência do Brasil. Porto: Litografia Nacional, 1921, tomo II.

MESGRAVIS, Laima. Os aspectos estamentais da estrutura social no Brasil colônia. Estudos Econômicos. São Paulo: IPE-USP, vol. 13. 1983.

MORAES, José Rubens de. Evolução histórica da execução civil no direito lusitano. São Paulo, 2002. Dissertação de Mestrado (Mestrado em Direito) - Faculdade de Direito, Universidade de São Paulo.

MONTEIRO, John. Negros da terra: índios e bandeirantes nas origens de São Paulo. São Paulo: Companhia das Letras, 1994.

MONTEIRO, Nuno Gonçalo. Elites e poder. Entre o Antigo Regime e o Liberalismo. Lisboa: ICSUL, 2007. . "Os concelhos e as comunidades. In HESPANHA, António M. (org.)

História de Portugal, Lisboa: Estampa, 1994.

MORSE, Richard. A evolução das cidades latino-americanas. Cadernos CEBRAP. São Paulo: Brasiliense, 22, 1975.

DIFEL, 1970.[ 1 1ª edição, 1958].

MOTTA, Márcia M. Direito à terra no Brasil: a gestação do conflito (1795-1824). São Paulo: Alameda, 2009.

OLIVEIRA MARQUES, António Henrique de. Guia do estudante de história medieval portuguesa. Lisboa: Cosmos, 1964.

OMEGNA, Nelson. A cidade colonial. Rio de Janeiro: J. Olympio, 1961.

PAES LEME, Pedro Taques de Almeida. História da capitania de São Vicente. São Paulo: Melhoramentos, 1954. [1 $1^{\mathrm{a}}$ edição, 1772].

s.n, 1870 . . Nobiliarchia paulistana: genealogia das principaes familias de S. Paulo. s.1: . Nobiliarquia paulistana. São Paulo: Comissão do IV Centenário, 1954. . Nobiliarquia paulistana. Belo Horizonte: Itatiaia/EdUSP, 1980.

PRADO Jr., Caio. A cidade de São Paulo. Geografia e história. São Paulo: Brasiliense, 1983. . Formação do Brasil Contemporâneo. São Paulo: Brasiliense, 1942.

RAMA, Ángel. A cidade e as letras. São Paulo: Brasiliense, 1985. 
RAU, Virgínia. Sesmarias medievais portuguesas. Lisboa: Presença, 1982.

REVISTA do Arquivo Municipal. São Paulo: DPH, v. 191, 1992.

REIS FILHO, Nestor Goulart. Contribuição ao estudo da evolução urbana no Brasil. São Paulo: Pioneira, 1968. . Quadro da arquitetura no Brasil. São Paulo: Perspectiva, 2006. . São Paulo vila cidade metrópole. São Paulo: Via das Artes, 2004.

RICUPERO, Rodrigo. A formação da elite colonial. São Paulo: Alameda, 2009.

RIGON FILHO, Ângelo. Evolução histórica da filiação no direito brasileiro. São Paulo, 2005. Dissertação de mestrado (Mestrado em Direito) - Faculdade de Direito, Universidade de São Paulo.

ROMERO, Silvio. Historia da litteratura brazileira. Rio de Janeiro: Garnier, 1888, 2 vol.

SALDANHA, António Vasconcelos de. As capitanias. O regime senhorial na Expansão Ultramarina Portuguesa. Funchal: CEHA, 1992.

SALGADO, Plínio. Como nasceram as cidades?. São Paulo: Voz do Oeste, 1978.

SAMPAIO, Francisco Coelho de Souza e. Prellecções de direito pátrio público e particular. Coimbra: Real Imprensa da Universidade, 1793.

SANTOS, Paulo. Formação de cidades no Brasil colonial. Rio de Janeiro: EdUFRJ, 2001. [1 ${ }^{\mathrm{a}}$ edição, 1968].

SANTOS, Shirley dos. Vila de Itu: a cristandade na boca do sertão (1732-1776). São Paulo, 2004. Dissertação de mestrado (História Social) - Faculdade de Filosofia, Letras e Ciências Humanas, Universidade de São Paulo.

SCHWARZ, Stuart. Burocracia e sociedade no Brasil colonial. São Paulo: Perspectiva, 1979. [1 ${ }^{\mathrm{a}}$ edição, 1973].

SILVA, Ligia Osório. Terras devolutas e latifúndio: efeitos da Lei de 1850. Campinas: UNICAMP, 1996.

SILVA LEME, Luis Gonzaga da. Genealogia Paulistana. São Paulo: Duprat \& Comp., 1903, 9 vol.

SOUSA, Washington Luís Pereira de. Contribuição para a historia da capitania de São Paulo (governo de Rodrigo César de Menezes). Revista do Instituto Histórico e Geográfico Brasileiro. São Paulo, vol. 8, 1904.

TAPAJÓS, Vicente. Prefácio. In: Vicente Tapajós (org.). História Administrativa do Brasil. Rio de Janeiro: Imprensa Nacional, 1956, vol. 1. 
A política administrativa de D. João III. In: Vicente Tapajós (org. ). História Administrativa do Brasil. Rio de Janeiro: Imprensa Nacional, 1956, vol. 2.

TAUNAY, Alfredo D'Escragnolle. A administração manuelina. In: Vicente Tapajós (org.). História Administrativa do Brasil. Rio de Janeiro: Imprensa Nacional, 1956, vol. 1.

TAUNAY, Afonso de E. História geral das bandeiras paulistas. São Paulo: Ideal, vol. VIII. . História seiscentista da villa de São Paulo. São Paulo: Ideal, 1926, 4 vol. $\overline{I H G S P, \text { v. 38, } 1940 .}$

. Silva Leme e o povoamento do Brasil central pelos paulistas. Revista do . São Paulo nos primeiros anos e São Paulo no século XVI. São Paulo, Paz e Terra, 2004. [1 $1^{\text {a }}$ edição, 1920]. . Pedro Taques e o seu tempo. São Paulo: Diario Official, 1923.

. Prefácio. In: PAES LEME, Pedro Taques de Almeida. Nobiliarquia paulistana. São Paulo: Comissão do IV Centenário, 1954.

TORRÃO FILHO, Amílcar. Paradigma do caos ou cidade da conversão?. São Paulo: FAPESP; Annablume, 2007.

TRÍPOLI, César. História do direito brasileiro (ensaio). São Paulo: Revista dos Tribunais, 1936, vol. 1.

VARNHAGEN, Francisco Adolfo de. História geral do Brasil. São Paulo: Melhoramentos, 19--, 5 vol.

VELASCO, Ignacio M. Poveda. Ordenações do Reino. Revista da Faculdade de Direito da Universidade de São Paulo. São Paulo, v. 89, jan/dez, 1994.

WEBER, Max. Economia e sociedade. Brasília: EdUnB, São Paulo: Imprensa Oficial, 1999-2000, 2 v.. [1 ${ }^{\mathrm{a}}$ edição, 1925].

ZENHA, Edmundo. O município no Brasil. São Paulo: I.P.E., 1948. 